\title{
Assessing Water Quality From Highway Runoff at Selected Sites in North Carolina with the Stochastic Empirical Loading and Dilution Model (SELDM)
}

Scientific Investigations Report 2019-5031 Version 1.1, July 2019

U.S. Department of the Interior U.S. Geological Survey
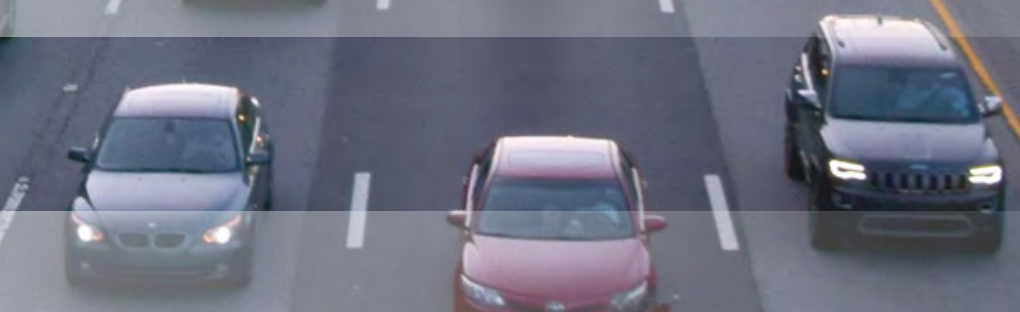
Cover. Morning rush hour traffic on Interstate 40 West at Wade Avenue interchange near Cary, North Carolina, May 14, 2019.

Photograph by J. Curtis Weaver, U.S. Geological Survey. 


\section{Assessing Water Quality From Highway Runoff at Selected Sites in North Carolina with the Stochastic Empirical Loading and Dilution Model (SELDM)}

By J. Curtis Weaver, Gregory E. Granato, and Sharon A. Fitzgerald

Prepared in cooperation with the North Carolina Department of Transportation, Division of Highways, Hydraulics Unit and the U.S. Department of Transportation, Federal Highway Administration, Office of Project Development and Environmental Review

Scientific Investigations Report 2019-5031

Version 1.1, July 2019 


\title{
U.S. Department of the Interior \\ DAVID BERNHARDT, Secretary
}

\section{U.S. Geological Survey James F. Reilly II, Director}

\author{
U.S. Geological Survey, Reston, Virginia: 2019 \\ First release: May 20, 2019, online \\ Revised: July 2, 2019 (ver. 1.1), online
}

For more information on the USGS - the Federal source for science about the Earth, its natural and living resources, natural hazards, and the environment-visit https://www.usgs.gov or call 1-888-ASK-USGS (1-888-275-8747).

For an overview of USGS information products, including maps, imagery, and publications, visit https://store.usgs.gov.

Any use of trade, firm, or product names is for descriptive purposes only and does not imply endorsement by the U.S. Government.

Although this information product, for the most part, is in the public domain, it also may contain copyrighted materials as noted in the text. Permission to reproduce copyrighted items must be secured from the copyright owner.

Suggested citation:

Weaver, J.C., Granato, G.E., and Fitzgerald, S.A., 2019, Assessing water quality from highway runoff at selected sites in North Carolina with the Stochastic Empirical Loading and Dilution Model (SELDM) (ver. 1.1, July 2, 2019): U.S. Geological Survey Scientific Investigations Report 2019-5031, 99 p., https://doi.org/10.3133/sir20195031.

ISSN 2328-0328 (online) 


\section{Acknowledgments}

The authors thank Stephen Morgan, Matthew Lauffer, Andy McDaniel, Ryan Mullins, and Brian Lipscomb of the North Carolina Department of Transportation (NCDOT) Hydraulics Unit for their support of the project. Their knowledge and insight of stormwater-quality issues across North Carolina provided valuable guidance for the analyses completed during this study. Appreciation is also expressed to Caleb Whitby, Quynh Nguyen, and Nishant Shah (also with the NCDOT Hydraulics Unit), who assisted in the development of recession ratio statistics for 28 selected streamgages across North Carolina. The authors acknowledge Susan C. Jones, Highway Engineer, Federal Highway Administration Office of Project Development and Environmental Review, whose technical insight and programmatic support continue to support the development and use of the Stochastic Empirical Loading and Dilution Model (SELDM).

Karthik Narayanaswamy, project manager and environmental consultant on water-quality data with AECOM (subcontractor for the NCDOT), compiled the North Carolina highway-runoff waterquality data from nine reports identified by the NCDOT.

This U.S. Geological Survey (USGS) project was completed under the supervisory guidance of Jeanne Robbins, Chad Wagner, John Shelton, and Jason Fine. Amber Churchill (USGS) assisted in the compilation of StreamStats basin characteristics for selected continuous-record streamgages in North Carolina, and Ashlyann Arana-Morales (USGS student intern) assisted in the development of preliminary illustrations and tables for the water-quality transport curve analyses.

Chad Wagner, Toby Feaster, and Adam Stonewall (all with the USGS) provided content and technical reviews that improved this report. Rachel Gidley and Jeff Corbett with the USGS provided editorial review and design services, respectively. 


\section{Contents}

Acknowledgments .......................................................................................................................ii

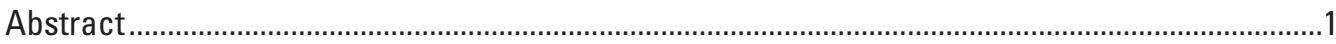

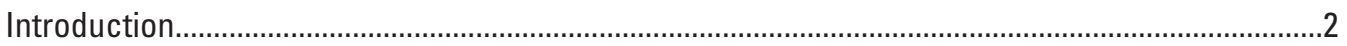

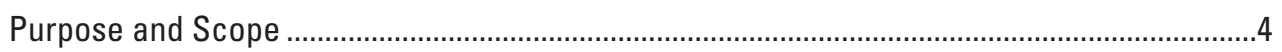

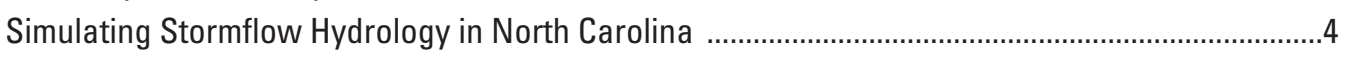

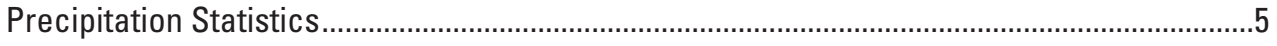

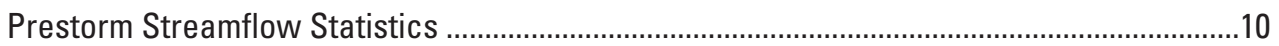

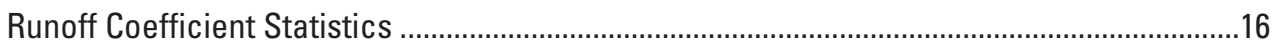

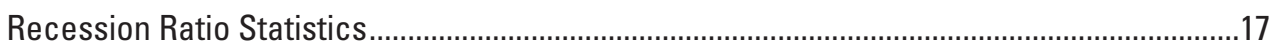

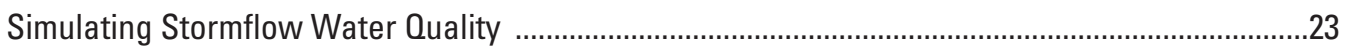

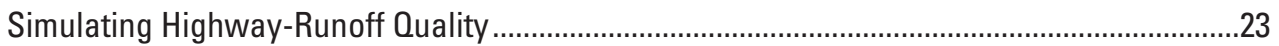

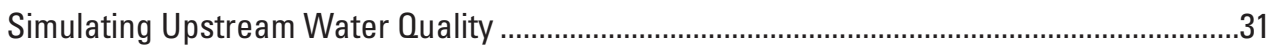

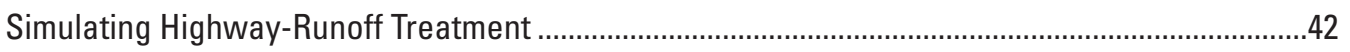

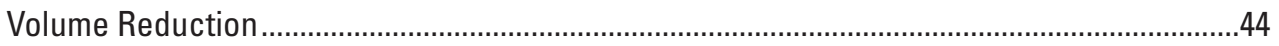

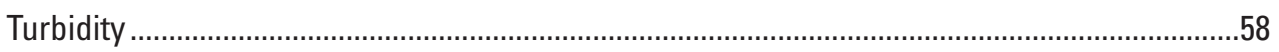

Total Suspended Solids.......................................................................................................

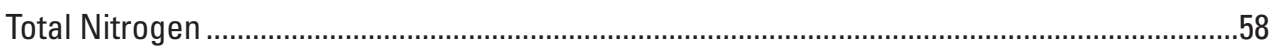

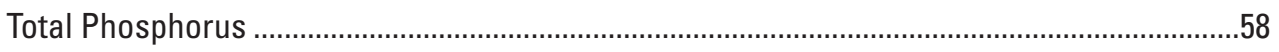

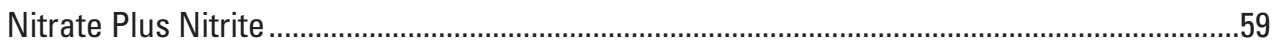

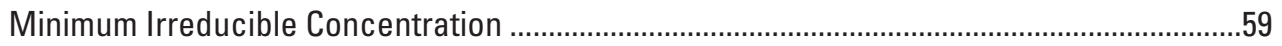

Example Simulations of the North Carolina-Enhanced SELDM .......................................................59

Hypothetical Highway Catchment ..................................................................................59

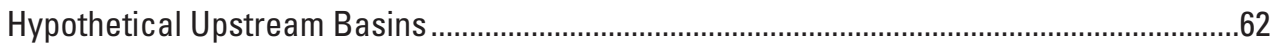

Simulations Group 1: Varying Drainage Area for Upstream Basin ..........................................64

Simulations Group 2: Varying Precipitation, Upstream Stormflow, and Recession Ratio ......66

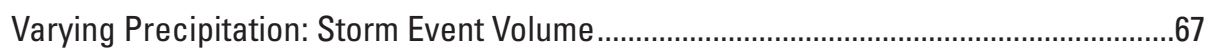

Varying Upstream Stormflow: Average Discharge ...........................................................69

Varying Recession Ratio: Most Probable Value Recession Ratio ....................................69

Simulations Group 3: Varying Upstream Water-Quality Transport Curves.................................72

Varying Suspended Sediment Concentration ......................................................................

Varying Total Nitrogen..........................................................................................

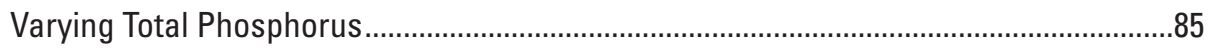

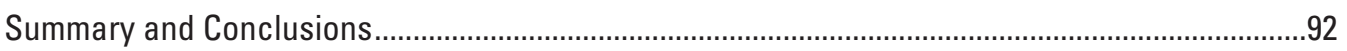

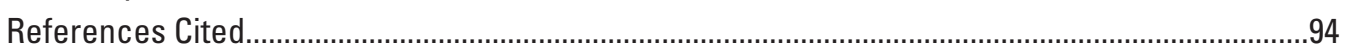




\section{Figures}

1. Schematic diagram showing the stochastic mass-balance approach for estimating stormflow, concentration, and loads of water-quality constituents upstream from a highway-runoff outfall, from the highway, and downstream from the outfall...

2. Schematic diagram showing the upstream stormflow and highway-runoff components that must be estimated for a mass-balance analysis of receiving-water quality. .5

3. Map showing 92 selected National Oceanic and Atmospheric Administration National Weather Service hourly precipitation stations within and near North Carolina and Parameter-elevation Regressions on Independent Slopes Model average annual precipitation for 1981-2010.

4. Map showing 266 selected U.S. Geological Survey continuous-record streamgages in western and eastern North Carolina used to determine prestorm streamflow statistics for the North Carolina Stochastic Empirical Loading and Dilution Model study

5. Graphs showing relations between national Stochastic Empirical Loading and Dilution Model and updated North Carolina SELDM retransformed log10 streamflow statistics for 84 U.S. Geological Survey streamgages across North Carolina that are concurrent in the national SELDM and updated North Carolina SELDM databases

6. Screenshots of the U.S. Geological Survey StreamStats application showing the Streamgages pop-up window and StreamStats Data-Collection Station Report where updated streamflow statistics computed for the North Carolinaenhanced Stochastic Empirical Loading and Dilution Model can be accessed.

7. Graph showing the mean runoff coefficients for Stochastic Empirical Loading and Dilution Model and North Carolina highway- and nonhighway-runoff monitoring sites.

8. Map showing 39 North Carolina Department of Transportation-partner highway-runoff sampling sites across North Carolina for which water-quality and storm-event data were added to the national Highway-Runoff Database and 27 selected U.S. Geological Survey continuous-record streamgages for which water-quality transport curves were developed.

9. Graphs showing examples of development and use of a two-segment water-quality transport curve for stochastic generation of suspended sediment concentration for site TC4

10. Boxplots showing ranges in simulated suspended sediment concentrations among 18 water-quality transport curves developed for the North Carolina Stochastic Empirical Loading and Dilution Model study

11. Boxplots showing ranges in simulated total nitrogen concentrations among 12 water-quality transport curves developed for the North Carolina Stochastic Empirical Loading and Dilution Model study...

12. Boxplots showing ranges in simulated total phosphorus concentrations among eight water-quality transport curves developed for the North Carolina Stochastic Empirical Loading and Dilution Model study

13. Graph showing fitted cumulative trapezoidal-distribution functions of the total suspended solids concentration-reduction statistics for grass swale best management practice sites in North Carolina. 
14. Scatterplots showing the relations between drainage area and drainage length and drainage area and channel slope for selected basins in Georgia,

South Carolina, and North Carolina

15. Graphs showing stochastic populations of dilution factors for highway runoff generated without best management practice statistics and with volume-reduction statistics for grass swale BMPs for a Piedmont rural basin with drainage areas varying from 1 to 100 square miles

16. Graphs showing stochastic populations of dilution factors for highway runoff for rural and urban 25-square-mile Piedmont basins based on use of average, minimum, and maximum storm-event volume for the Stochastic Empirical Loading and Dilution Model precipitation stations in the Piedmont ecoregion.

17. Graphs showing stochastic populations of dilution factors for highway runoff for 25-square-mile rural and urban Piedmont basins based on use of average, minimum, and maximum geometric log10 mean discharge for selected North Carolina Stochastic Empirical Loading and Dilution Model streamgages in the Piedmont ecoregion.

18. Graphs showing stochastic populations of dilution factors for highway runoff for rural and urban 25-square-mile Piedmont basins based on use of minimum, median, and maximum most probable value recession ratio for selected North Carolina Stochastic Empirical Loading and Dilution Model streamgages in the Piedmont ecoregion.

19. Graph showing suspended sediment event mean concentrations in upstream flow, highway runoff, and downstream flow simulated for Piedmont rural creek by using the upstream transport curve for site TC19, which represents the low range of potential suspended sediment concentrations from the upstream basin

20. Graph showing suspended sediment event mean concentrations in upstream flow, highway runoff, and downstream flow simulated for Piedmont rural creek by using the upstream transport curve for site TC4, which represents the medium range of potential suspended sediment concentrations from the upstream basin.

21. Graph showing suspended sediment event mean concentrations in upstream flow, highway runoff, and downstream flow simulated for Piedmont rural creek by using the upstream transport curve for site TC20, which represents the high range of potential suspended sediment concentrations from the upstream basin

22. Graph showing total nitrogen event mean concentrations in upstream flow, highway runoff, and downstream flow simulated for Piedmont rural creek by using the upstream transport curve for site TC27, which represents the low range of potential total nitrogen concentrations from the upstream basin, without and with best management practice treatment.

23. Graph showing total nitrogen event mean concentrations in upstream flow, highway runoff, and downstream flow simulated for Piedmont rural creek by using the upstream transport curve for site TC24, which represents the medium range of potential total nitrogen concentrations from the upstream basin, without and with best management practice treatment.

24. Graph showing total nitrogen event mean concentrations in upstream flow, highway runoff, and downstream flow simulated for Piedmont rural creek by using the upstream transport curve for site TC6, which represents the high range of potential total nitrogen concentrations from the upstream basin, without and with best management practice treatment. 
25. Boxplots showing ranges in simulated annual total flow for highway runoff without best management practice treatment, with grass swale BMP

treatment, and with bioretention BMP treatment.

26. Boxplots showing ranges in simulated total nitrogen annual load yield for highway runoff without best management practice treatment, with (post) grass swale BMP treatment, and with bioretention BMP treatment

27. Graph showing total phosphorus event mean concentrations in upstream flow, highway runoff, and downstream flow simulated for Piedmont rural creek by using the upstream transport curve for site TC4, which represents the low range of potential total phosphorus concentrations from the upstream basin, without and with best management practice treatment

28. Graph showing total phosphorus event mean concentrations in upstream flow, highway runoff, and downstream flow simulated for Piedmont rural creek by using the upstream transport curve for site TC15, which represents the medium range of potential total phosphorus concentrations from the upstream basin, without and with best management practice treatment

29. Graph showing total phosphorus event mean concentrations in upstream flow, highway runoff, and downstream flow simulated for Piedmont rural creek by using the upstream transport curve for site TC24, which represents the high range of potential total phosphorus concentrations from the upstream basin, without and with best management practice treatment

30. Boxplots showing ranges in simulated total phosphorus annual load yield for highway runoff without best management practice treatment, with grass swale BMP treatment, and with bioretention BMP treatment

\section{Tables}

1. Summary of site attributes for 92 selected National 0 ceanic and Atmospheric Administration National Weather Service hourly precipitation stations within and near North Carolina

2. Median percentage change of selected streamflow statistics for 84 U.S. Geological Survey streamgages in North Carolina that are concurrent in the national Stochastic Empirical Loading and Dilution Model and updated North Carolina SELDM databases

3. Statistics used to estimate the confidence intervals of the average runoff coefficient equations

4. Best-fit triangular-hydrograph recession ratios estimated from 22 or more storm-event hydrographs at 30 selected U.S. Geological Survey continuous-record streamgages in North Carolina.

5. Summary of North Carolina Department of Transportation-partner highway-runoff research reports and water-quality data compiled for upload to the national Highway-Runoff Database and for use in best management practice performance analyses.

6. Summary of North Carolina Department of Transportation-partner highway-runoff sampling sites and selected attributes for water-quality data uploaded to the national Highway-Runoff Database.

7. Statewide medians of statistics for selected water-quality constituents at North Carolina highway-runoff sites

8. Water-quality transport-curve statistics for selected constituents at 27 U.S. Geological Survey streamgages in North Carolina 
9. Stormwater control measure best management practice (BMP) performance flow-reduction and hydrograph-extension statistics for sites throughout the United States

10. Stormwater control measure best management practice (BMP) performance concentration-reduction statistics for sites throughout the United States

11. Summary of stormflow volume-reduction statistics for the trapezoidal distribution for grass swale best management practice (BMP) sites from North Carolina Department of Transportation-partner highway-runoff studies.

12. Summary of turbidity water-quality treatment statistics for the trapezoidal distribution for grass swale best management practice (BMP) sites from North Carolina Department of Transportation-partner highway-runoff studies.

13. Summary of total suspended solids water-quality treatment statistics for the trapezoidal distribution for best management practice (BMP) sites from North Carolina Department of Transportation-partner highway-runoff studies.

14. Summary of total nitrogen water-quality treatment statistics for the trapezoidal distribution for best management practice (BMP) sites from North Carolina Department of Transportation-partner highway-runoff studies.

15. Summary of total phosphorus water-quality treatment statistics for the trapezoidal distribution for best management practice (BMP) sites from North Carolina Department of Transportation-partner highway-runoff studies.

16. Summary of nitrate plus nitrite (NO3 + NO2) water-quality treatment statistics for the trapezoidal distribution for best management practice (BMP) sites from North Carolina Department of Transportation-partner highway-runoff studies

17. Summary of site characteristics for a hypothetical North Carolina upstream basin and a hypothetical four-lane highway used for North Carolina Stochastic Empirical Loading and Dilution Model (SELDM) simulations

18. Percentage of storm events in which dilution factors equaled or exceeded 0.1 for highway runoff without best management practice (BMP) treatment and with volume-reduction grass swale BMP for a Piedmont rural basin with drainage area varying from 1 to 100 square miles (mi2)

19. Percentage of storm events in which dilution factors equaled or exceeded 0.1 for highway runoff for rural and urban 25-square-mile Piedmont basins based on use of average, minimum, and maximum statistics for selected precipitation, streamflow, and recession ratio Stochastic Empirical Loading and Dilution Model input variables.

20. Simulated suspended sediment concentrations equaled or exceeded in the highway runoff, upstream stormflow, and downstream stormflow for selected percentages of storm events.

21. Simulated total nitrogen concentrations equaled or exceeded in the highway runoff, upstream stormflow, and downstream stormflow for selected percentages of storm events, without and with a grass swale best management practice (BMP) applied to the highway-runoff component.

22. Simulated total nitrogen concentrations equaled or exceeded in the highway runoff, upstream stormflow, and downstream stormflow for selected percentages of storm events, without and with a bioretention best management practice (BMP) applied to the highway-runoff component.

23. Simulated total phosphorus concentrations equaled or exceeded in the highway runoff, upstream stormflow, and downstream stormflow for selected percentages of storm events, without and with a grass swale best management practice (BMP) applied to the highway-runoff component. 
24. Simulated total phosphorus concentrations equaled or exceeded in the highway runoff, upstream stormflow, and downstream stormflow for selected percentages of storm events, without and with a bioretention best management practice (BMP) applied to the highway-runoff component.

\section{Conversion Factors}

U.S. customary units to International System of Units

\begin{tabular}{|c|c|c|}
\hline Multiply & By & To obtain \\
\hline \multicolumn{3}{|c|}{ Length } \\
\hline inch (in.) & 25.4 & millimeter $(\mathrm{mm})$ \\
\hline foot $(\mathrm{ft})$ & 0.3048 & meter $(\mathrm{m})$ \\
\hline mile (mi) & 1.609 & kilometer (km) \\
\hline \multicolumn{3}{|c|}{ Area } \\
\hline acre & 0.4047 & hectare (ha) \\
\hline acre & 0.004047 & square kilometer $\left(\mathrm{km}^{2}\right)$ \\
\hline square foot $\left(\mathrm{ft}^{2}\right)$ & 0.09290 & square meter $\left(\mathrm{m}^{2}\right)$ \\
\hline square mile $\left(\mathrm{mi}^{2}\right)$ & 2.590 & square kilometer $\left(\mathrm{km}^{2}\right)$ \\
\hline \multicolumn{3}{|c|}{ Flow rate } \\
\hline cubic foot per second $\left(\mathrm{ft}^{3} / \mathrm{s}\right)$ & 0.02832 & cubic meter per second $\left(\mathrm{m}^{3} / \mathrm{s}\right)$ \\
\hline $\begin{array}{l}\text { cubic foot per second per } \\
\text { square mile }\left(\left[\mathrm{ft}^{3} / \mathrm{s}\right] / \mathrm{mi}^{2}\right)\end{array}$ & 0.01093 & $\begin{array}{l}\text { cubic meter per second per } \\
\text { square kilometer }\left(\left[\mathrm{m}^{3} / \mathrm{s}\right] / \mathrm{km}^{2}\right)\end{array}$ \\
\hline \multicolumn{3}{|c|}{ Mass } \\
\hline pound, avoirdupois (lb) & 0.4536 & kilogram $(\mathrm{kg})$ \\
\hline \multicolumn{3}{|c|}{ Hydraulic gradient } \\
\hline foot per mile (ft/mi) & 0.1894 & meter per kilometer $(\mathrm{m} / \mathrm{km})$ \\
\hline
\end{tabular}

\section{Datum}

Vertical coordinate information is referenced to the North American Vertical Datum of 1988 (NAVD 88) or the National Geodetic Vertical Datum of 1929 (NGVD 29).

Horizontal coordinate information is referenced to the North American Datum of 1983 (NAD 83).

Elevation, as used in this report, refers to distance above the vertical datum.

\section{Abbreviations}

1B3

4B3

7010

BDF

BMP

EMC

EPA 1-day 3-year biological flow

4-day 3-year biological flow

7-day 10-year low-flow discharge

basin development factor

best management practice

event mean concentration

U.S. Environmental Protection Agency 


\begin{tabular}{|c|c|}
\hline FHWA & Federal Highway Administration \\
\hline GIS & geographic information system \\
\hline GNWISQ & Get National Water Information System Streamflow (0) \\
\hline HRDB & Highway-Runoff Database \\
\hline KTRLine & Kendall-Theil Robust Line software \\
\hline LBMPV & lower bound of the most probable value \\
\hline $\log 10$ & common (base 10) logarithm \\
\hline MAD & median absolute deviation \\
\hline $\operatorname{maxRR}$ & maximum recession ratio \\
\hline MIC & minimum irreducible concentration \\
\hline $\operatorname{minRR}$ & minimum recession ratio \\
\hline mpvRR & most probable value recession ratio \\
\hline NOAA & National Oceanic and Atmospheric Administration \\
\hline NCDOT & North Carolina Department of Transportation \\
\hline NWIS & National Water Information System \\
\hline NWS & National Weather Service \\
\hline pcode & U.S. Environmental Protection Agency parameter code \\
\hline PRISM & Parameter-elevation Regressions on Independent Slopes Model \\
\hline QSTATS & Streamflow (0) Statistics software \\
\hline SELDM & Stochastic Empirical Loading and Dilution Model \\
\hline SPAF & Synoptic Precipitation Analysis Facilitator software \\
\hline SSC & suspended sediment concentration \\
\hline SWODM & Surface Water Quality Data Miner database \\
\hline TN & total nitrogen \\
\hline TP & total phosphorus \\
\hline TSS & total suspended solids \\
\hline UBMPV & upper bound of the most probable value \\
\hline USGS & U.S. Geological Survey \\
\hline WOABI & Water Quality Assessed by Benthic macroinvertebrate health ratings \\
\hline WTTP & wastewater treatment plant \\
\hline
\end{tabular}




\title{
Assessing Water Quality from Highway Runoff at Selected Sites in North Carolina with the Stochastic Empirical Loading and Dilution Model (SELDM)
}

\author{
By J. Curtis Weaver, Gregory E. Granato, and Sharon A. Fitzgerald
}

\section{Abstract}

In 2015, the U.S. Geological Survey (USGS) entered into a cooperative agreement with the North Carolina Department of Transportation (NCDOT) to develop a North Carolina-enhanced variation of the national Stochastic Empirical Loading and Dilution Model (SELDM) with available North Carolinaspecific streamflow and water-quality data and to demonstrate use of the model by documenting selected simulation scenarios. The USGS developed the national SELDM in cooperation with the Federal Highway Administration (FHWA) to provide the tools and techniques necessary for performing stormwaterquality simulations. SELDM uses a stochastic mass-balance approach to estimate combinations of flows, concentrations, and loads of stormwater constituents from the site of interest (often a highway catchment; nonhighway areas, such as a large impervious area at a shopping center complex, also can be used) and the basin upstream from the stormwater outfall to assess the risk for adverse effects of runoff. SELDM also can be used to simulate the effectiveness of volume reduction, hydrograph extension, and water-quality concentration reductions by stormwater best management practices (BMPs), which are designed to help mitigate the effects of runoff on receiving water bodies.

Some of the statistical inputs needed for the North Carolina-enhanced SELDM were either calculated or augmented using local or regional data from North Carolina. Streamflow statistics used by SELDM were determined for 266 streamgages across North Carolina on the basis of data available through the 2015 water year. Recession ratio statistics used for triangular hydrographs were also developed for 30 streamgages across the State. The NCDOT identified previous research reports on highway-runoff and BMP studies in North Carolina for review of potential data addition to the national FHWA Highway-Runoff Database (HRDB). Following USGS review of these data, a total of 25,087 event mean concentration values and 1,140 storm events for 39 highway-runoff sites and 195 analytes were uploaded to the national HRDB from six North Carolina highway-runoff research reports and a recent USGS bridge deck runoff study. Using data for 27 streamgages in North Carolina, a total of 57 water-quality transport curves were developed for seven constituents for use in simulating water-quality conditions in the upstream basin. Performance data for three BMPs (bioretention, grass strip or swale, and wetland channel) from NCDOT research data were incorporated into the North Carolina-enhanced SELDM for volume-reduction statistics, including the effectiveness of treating four waterquality constituents (total suspended solids, total nitrogen, total phosphorus, nitrate plus nitrite) and turbidity.

Simulations using the North Carolina-enhanced SELDM are presented for two hypothetical upstream basins in the Piedmont ecoregion and one hypothetical highway site to demonstrate how simulations can be used to provide riskbased information about potential effects of stormwater runoff on downstream water quality and the potential for mitigating those risks by using BMPs. The first group of simulations explores the stochastic variability in dilution factors (the ratio of the highway runoff to the total downstream stormflow) for a hypothetical Piedmont rural creek having drainage areas ranging from 1 to 100 square miles. The second group of simulations examines dilution factors based on variations in precipitation, streamflow, and recession ratios for two hypothetical Piedmont upstream basins (rural and urban) where the drainage area was held constant at 25 square miles. These simulations indicate the sensitivity of results to variations in each of the three variables. The third group of simulations examines the effects of varied concentrations in the upstream basin on water-quality conditions downstream from the highway crossing. Variations in upstream waterquality conditions for three constituents (suspended sediment concentration, total nitrogen, and total phosphorus) are based on water-quality transport curves selected from among the 57 curves developed as part of this study to represent low-, medium-, and high-concentration statistics. Simulations completed for this third group also examine the potential effects of grass swale and bioretention BMP treatment on total nitrogen and total phosphorus concentrations in highway runoff. The BMP performance data from the NCDOT research reports were applied in this group of simulations. 
The stochastic mass-balance approach used in SELDM analyses and simulations provides a strong tool for engineers and water-resource managers to use in exploring a wide range of possible hydrologic and water-quality inputs and their effects on downstream water quality. The results of this study can not only aid engineers and managers in planning for potential adverse effects of runoff at site-specific locations, they can also help the USGS and other Federal and State agencies with oversight responsibilities in stormwater-quality issues to continue gathering data on potential water-quality effects in receiving streams.

\section{Introduction}

The North Carolina Department of Transportation (NCDOT) maintains approximately 80,000 miles of primary and secondary roads in North Carolina. The NCDOT's responsibilities to manage runoff from its roadways according to State and Federal regulations and guidelines are of critical importance to its mission. The NCDOT began addressing potential adverse effects of highway runoff on receiving waters in 1970 through its Sediment and Erosion Control Program (North Carolina Department of Transportation, undated[a]). In 1998, the NCDOT established the Highway Stormwater Program to better address the risk for adverse effects of runoff and to develop methods to mitigate these risks. The program provides resources for the NCDOT to help protect and improve water quality as part of its mission to build and maintain the State's transportation infrastructure (North Carolina Department of Transportation, undated[b]). Through the Highway Stormwater Program, the NCDOT supports scientific research to characterize pollutant loading from roadways and to quantify the effectiveness of stormwater management practices.

Currently (2019), stormwater runoff from NCDOT property is managed under the provisions of the NCDOT's National Pollutant Discharge Elimination System permit issued by the North Carolina Department of Environmental Quality and the U.S. Environmental Protection Agency (EPA). As part of its Post-Construction Stormwater Program, the NCDOT is interested in understanding the quality and quantity of stormwater runoff from NCDOT facilities, the potential for stormwater runoff to adversely affect receiving-water quality, and the potential effectiveness of stormwater control measures or best management practices (BMPs) for reducing the adverse effects. Stormwater runoff, unlike discharges from sources such as wastewater treatment plants (WWTPs), is difficult to mitigate because the quantity and quality of runoff vary randomly and unexpectedly and because the discharge from transportation systems is from many small catchments distributed along linear corridors. Uncertainties in the longterm performance and costs for stormwater BMPs also are much greater than those for traditional treatment measures such as WWTPs (Taylor and others, 2014). The NCDOT needs to quantify the contribution of water-quality constituents from upstream watersheds and roadways to downstream water bodies at runoff discharge points to make data-driven decisions and help determine strategies for mitigating adverse effects to the maximum extent practicable.

The U.S. Geological Survey (USGS) in cooperation with the Federal Highway Administration (FHWA) developed the Stochastic Empirical Loading and Dilution Model (SELDM) to provide the tools and techniques necessary for simulating the effects of stormwater runoff on downstream water quality (Granato, 2013; Risley and Granato, 2014). SELDM uses Monte Carlo methods to generate a stochastic (randomly determined) population of the concentrations, flows, and loads of stormwater constituents needed to implement a mass-balance model for the site of interest, often a highway catchment, and the basin upstream from the stormwater outfall to assess the risk for adverse effects of runoff. SELDM also can be used to simulate the effectiveness of volume reduction, hydrograph extension, and concentration reductions by stormwater BMPs, which are designed to help mitigate the effects of runoff on the receiving water body (Granato, 2006, 2009, 2010, 2013; Granato and Cazenas, 2009; Granato and others, 2009). SELDM also produces a stochastic population of annual flows and loads that can be used to evaluate potential effects of runoff from a site of interest. Although SELDM is described as a highway-runoff model, it can be used to simulate runoff discharges from other land uses, for example, a large impervious area at a shopping center complex. By facilitating scenario simulation and sensitivity analysis, SELDM can be used to estimate the potential risk of downstream water-quality exceedances resulting from runoff. SELDM includes an assemblage of water-quantity and -quality components as shown in figure 1.

To facilitate nationwide use, SELDM comes pre-loaded with selected statistics for many hydrologic and water-quality variables (Granato, 2013). SELDM includes statistics for thousands of precipitation, streamflow, and receiving water-quality monitoring sites and statistics for hydraulic variables such as runoff coefficients, basin lagtimes, and other hydrograph timing variables from hundreds of sites nationwide. It also includes examples of highway-runoff concentration statistics from various parts of the country. Although many of the sites selected for the national application were in North Carolina and nearby States, the NCDOT wanted to evaluate and update the national datasets in SELDM to reflect the hydrology and water-quality characteristics that may be unique to North Carolina. In 2015, the USGS entered into a cooperative agreement with the NCDOT to develop a North Carolina-enhanced variation of the national SELDM with available North Carolina-specific streamflow and water-quality data and to demonstrate use of the model by providing example simulations for selected scenarios. This scientific information is needed to help decision makers assess and mitigate potential effects of highway runoff on receiving waters in North Carolina. 

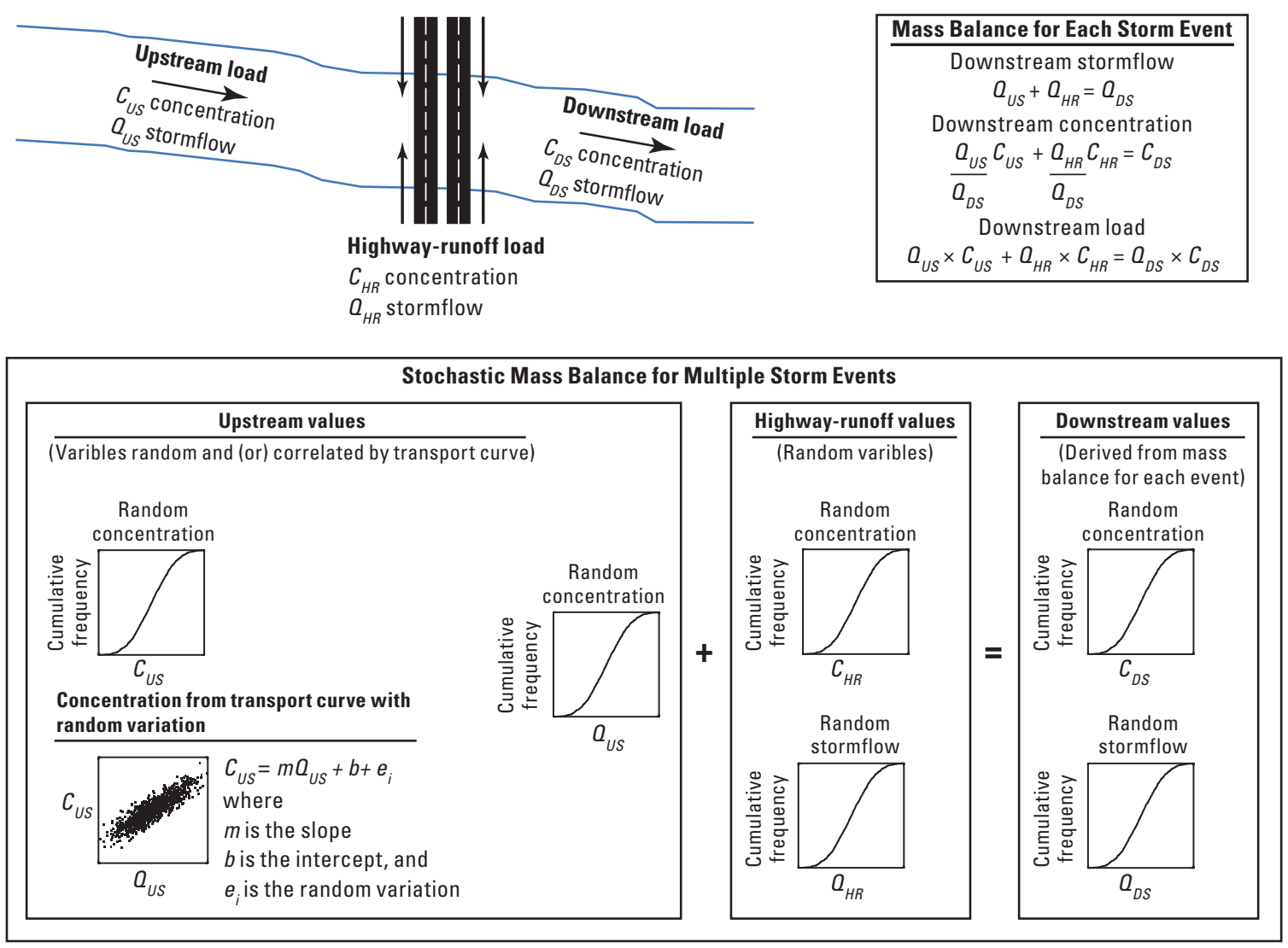

Figure 1. Schematic diagram showing the stochastic mass-balance approach for estimating stormflow, concentration, and loads of water-quality constituents upstream from a highway-runoff outfall, from the highway, and downstream from the outfall.

Hydrologic and water-quality data and statistics from sites in North Carolina were assembled and interpreted to support development of improved level-one, -two, or -three analyses (defined below) at sites in the State. SELDM is currently based on national datasets and does not fully utilize the NCDOT's extensive highway stormwater research data. SELDM's predictive accuracy for NCDOT applications could thus be enhanced by incorporating data specific to North Carolina and the NCDOT's stormwater management design and performance standards.

SELDM is designed to rapidly generate planning-level estimates with available information and data and to refine such estimates if necessary (Granato, 2013). Planning-level estimates are defined as the results of analyses used to evaluate alternative management measures. Such planning-level estimates are recognized to include substantial uncertainties (commonly orders of magnitude) in all aspects of the decision process (Barnwell and Krenkel, 1982; Marsalek and Ng, 1989; Marsalek, 1991). To support a step-by-step refinement process, SELDM is designed to facilitate initial estimates based on available regional statistics determined by the location of the site of interest, to help refine statistics by selecting data from nearby hydrologically similar sites, and to accept user-defined statistics. User-defined statistics may be calculated from available data or from newly collected data obtained during monitoring studies at the site of interest as conditions warrant. Considerable uncertainty may remain, however, even if sitespecific data are collected (Winter, 1981; Granato and others, 2003; Harmel and others, 2006; Granato, 2010, appendix 1; Smith and Granato, 2010).

SELDM provides the methods for three levels of analysis (Granato, 2013). In a level-one analysis, the user can quickly select regional statistics (based on ecoregion or rain zone) by site location; this level of analysis may provide the best estimates for sites where limited information is known. In a level-two analysis, the user can select data and statistics from one or more nearby and hydrologically similar sites. If data and statistics are preloaded into SELDM, a level-two analysis also can be done quickly and can improve on a level-one analysis. In a level-three analysis, the user can collect their own data at the site of interest and calculate statistics for simulating the quality and quantity of runoff with data from the given site. A level-three analysis will typically provide a better estimate than a level-two analysis. Studies have shown, however, that years or decades of data are needed to quantify hydrologic variations at a given site, and such data may not represent future conditions at a site of interest, especially because transportation projects are designed to support local and regional development patterns. In most cases, an analyst using SELDM will do a blended analysis by using a mixture 
of regional, local, and site-specific information to simulate the flows, concentrations, and loads of stormwater constituents at a site of interest.

SELDM uses the EPA Level III ecoregions (U.S. Environmental Protection Agency, 2003) as areas of hydrologic similarity to develop regional planning-level estimates of precipitation, prestorm streamflow, and upstream water quality. North Carolina contains parts of four EPA Level III ecoregions: Blue Ridge, Piedmont, Southeastern Plains, and Middle Atlantic Coastal Plain. The ecoregions were determined by analyzing the spatial patterns and composition of biotic and abiotic phenomena, including geology, physiography, vegetation, climate, soils, land use, wildlife, and hydrology (Griffith and others, 2002). Therefore, ecoregions represent areas of general similarity in ecosystems and in the type, quality, and quantity of environmental resources. These Level III ecoregions were used in the current study to evaluate the use of regional estimates with data from sites in and around North Carolina.

\section{Purpose and Scope}

The purpose of this study is (1) to document available streamflow and water-quality data from USGS and non-USGS records that are incorporated into the SELDM datasets, (2) to develop a North Carolina-enhanced variation of the national model, and (3) to demonstrate use of the model by providing example simulations for selected scenarios. Specific USGS data incorporated into the North Carolina-enhanced SELDM include selected North Carolina streamflow data and water-quality transport curves for selected constituents.

Streamflow statistics (based on data through the 2015 water year ${ }^{1}$ ) were computed for 266 selected continuousrecord streamgages and updated in the StreamStatsDB database, which is accessible from the USGS StreamStats application for North Carolina. Site-specific recession ratio statistics were developed for 30 selected continuous-record streamgages across North Carolina with drainage areas ranging from 4.12 to 63.3 square miles $\left(\mathrm{mi}^{2}\right)$. Water-quality transport curves based on data through the 2016 water year were developed at 27 streamgages for six water-quality constituents - suspended sediment concentration (SSC; U.S. Environmental Protection Agency parameter code [pcode] 80154), total nitrogen (TN; pcode 00600), total phosphorus (TP; pcode 00665), copper (pcode 01042), lead (pcode 01051), and zinc (pcode 01092) — and one water-quality characteristic: turbidity (pcode 63676). These constituents were selected from a larger list of constituents identified during the study design as being of particular interest to the NCDOT for management of stormwater runoff from highways.

\footnotetext{
${ }^{1}$ The annual period from October 1 through September 30, designated by the year in which the period ends.
}

The NCDOT identified North Carolina highway-runoff water-quality and -quantity data available from non-USGS sources (compiled by a private NCDOT contractor). These data were reviewed by the USGS and, if deemed acceptable, uploaded into the FHWA Highway-Runoff Database (HRDB), the data warehouse and preprocessor for SELDM (Granato and Cazenas, 2009; Smith and Granato, 2010; Granato and others, 2018). Performance data from selected highway-runoff and BMP site pairs were analyzed by using techniques documented in a national BMP study by Granato (2014) and incorporated into the North Carolina-enhanced SELDM for three BMP types.

Dilution factor and water-quality concentration simulations using the North Carolina-enhanced SELDM are documented in this report to demonstrate example effects and evaluations of stormwater runoff on downstream water quality for a hypothetical worst-case highway site and two Piedmont upstream basins. The constituents selected for the water-quality simulations were SSC, TN, and TP.

Although the scope of the study was limited to applications within North Carolina, information provided in this report may be useful to model users and decision makers elsewhere in the southeastern United States or other regions of the country. The methods used to collect and interpret data and statistics to build the North Carolina-enhanced SELDM can be used in other States because the concepts and examples used herein are applicable to runoff-quality challenges faced by decision makers across the Nation. This report provides examples for using SELDM but is not intended to be a supplementary manual for using the model. Numerous references to the manual (Granato, 2013) and other supporting documents are included to provide detailed information about the analysis methods used in the current study.

\section{Simulating Stormflow Hydrology in North Carolina}

SELDM uses storm-event (precipitation), prestorm streamflow, and runoff coefficient statistics to stochastically generate stormflow from the upstream basin and the highway site (fig. 2). The model also uses precipitation statistics, basin properties, and runoff-hydrograph statistics to stochastically generate runoff hydrographs from the highway and the upstream basin. Precipitation, surface water, and hydraulic data and statistics specific to North Carolina were compiled and analyzed to create and refine a North Carolinaenhanced variation of SELDM that represents hydrologic conditions in the State. Methods and techniques developed and documented for the national SELDM were used to analyze these North Carolina-specific hydrologic data and statistics (Granato, 2006, 2009, 2012, 2013, 2014; Granato and Cazenas, 2009). 


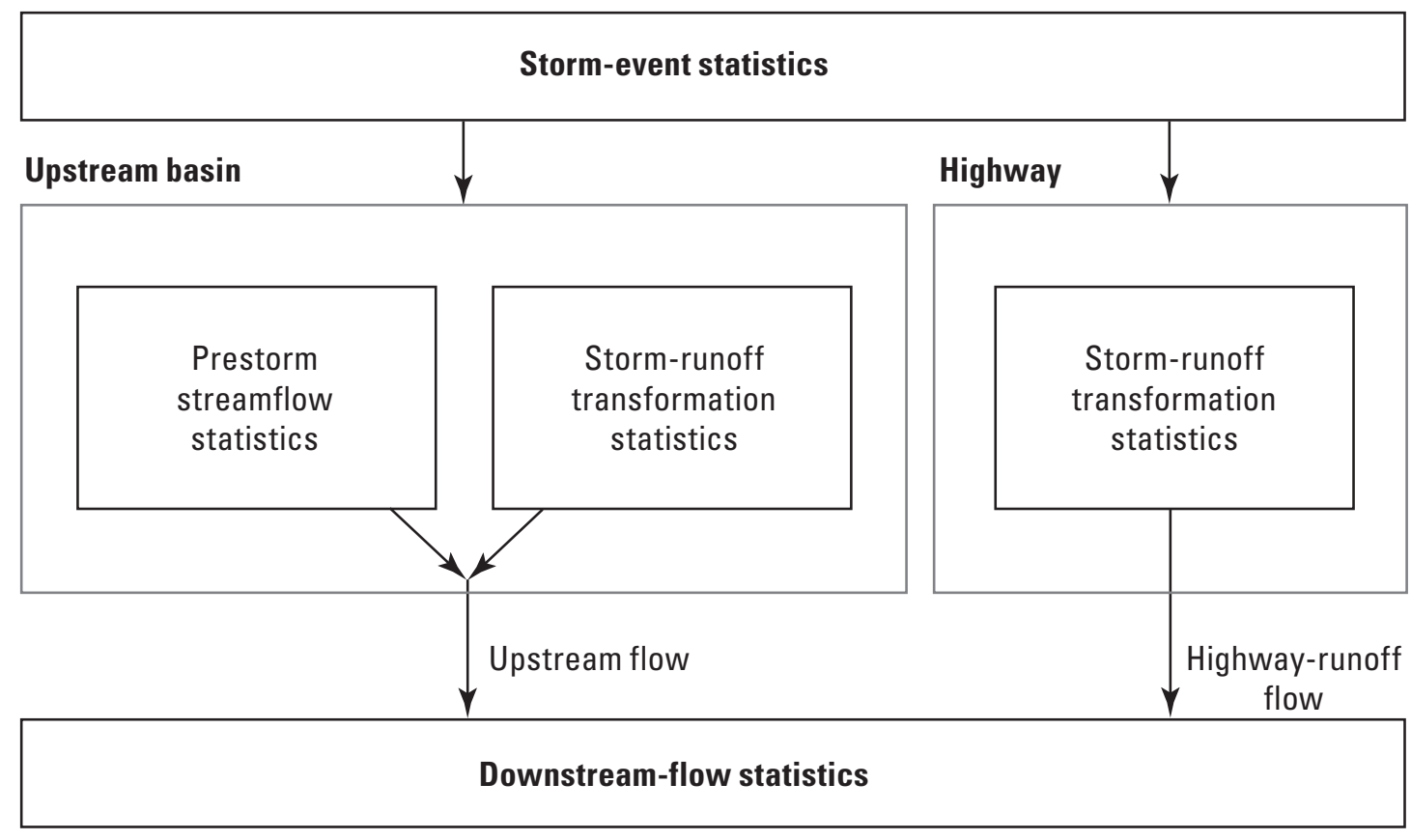

Figure 2. Schematic diagram showing the upstream stormflow and highway-runoff components that must be estimated for a mass-balance analysis of receiving-water quality.

\section{Precipitation Statistics}

SELDM uses precipitation statistics to stochastically simulate the number, volume, and duration of runoffgenerating events and the time between events. Storm-event precipitation statistics define the characteristics of each storm event and the number of events in the simulation (Risley and Granato, 2014). SELDM uses the EPA definition of a runoff-generating event, which is based on hourly precipitation values, a minimum precipitation volume of 0.1 inch (in.), and a minimum inter-event period of 6 hours (Driscoll, Palhegyi and others, 1989; Granato, 2010; 2013). Required storm-event statistics include the event volume (in inches), event duration (in hours), and the time between event midpoints (in hours). The SELDM output also documents the number of events per year and total annual precipitation (in inches) to facilitate analysis of hydrologic similarity among neighboring sites. SELDM allows users to select statistics by rain zone or ecoregion (for a level-one analysis), select statistics from one or more nearby National Weather Service (NWS) hourly precipitation stations (for a level-two analysis), or enter their own precipitation statistics (for a level-three analysis). The precipitation statistics are used with runoff coefficient statistics to generate the upstream-basin and highway-catchment storm discharges (fig. 2). SELDM uses Monte Carlo methods to stochastically calculate the storm-event characteristics, and the methods and data used for estimating these statistics are documented in detail in Granato (2010).

For the national SELDM, a total of 2,610 NWS hourly precipitation stations with period of record (POR) from 1965 to 2009 were used to compile storm-event characteristics into a national dataset, of which 40 of these sites are located within
North Carolina (Granato, 2010). In the current study, available USGS, U.S. Forest Service, Bureau of Land Management, Natural Resources Conservation Service, and North Carolina Climate Office precipitation dataset records were searched to determine if non-National Oceanic and Atmospheric Administration (NOAA) hourly precipitation stations in North Carolina with a minimum of 25 years of continuous data were available to supplement the national dataset. Two additional sites with 25 years of robust hourly precipitation data were identified; however, the data were not readily converted to the data formats necessary to calculate the SELDM precipitation statistics. Therefore, the analysis of precipitation data was limited to the 40 sites within North Carolina and 52 additional NWS hourly precipitation stations in the surrounding States of Virginia, Tennessee, Georgia, and South Carolina. These 92 sites are included in the national and North Carolinaenhanced SELDM (table 1, fig. 3).

Granato (2010) documented three computer programs (Synoptic Precipitation Analysis Facilitator [SPAF], SYNPREP, and SYNOP2000) and the procedures needed to compute and update SELDM precipitation statistics as part of an area-wide assessment. Initial consideration of the 92 sites from the national dataset included plans to use these programs to update the SELDM precipitation statistics by using newly obtained NOAA hourly precipitation data beyond 2009. However, the data format required for these programs is a legacy format that was no longer available after 2013, and a new format for the NOAA hourly precipitation dataset was under development during the precipitation analysis portion of the current study (Scott Stephens, National Centers for Environmental Information, written commun., May 27, 2016). 
Table 1. Summary of site attributes for 92 selected National Oceanic and Atmospheric Administration (NOAA) National Weather Service (NWS) hourly precipitation stations within and near North Carolina.

[Site attributes are from Granato (2010). Precipitation stations outside of North Carolina were selected by using a geographic information system overlay of Parameter-elevation Regressions on Independent Slopes Model map of average annual precipitation in and near North Carolina. For cross reference, field names shown in parentheses are from the national Stochastic Empirical Loading and Dilution Model precipitation dataset (Granato, 2010). POR, period of record]

\begin{tabular}{|c|c|c|c|c|c|c|c|}
\hline $\begin{array}{l}\text { Precipitation } \\
\text { site index } \\
\text { number } \\
\text { (HPStation_ID) } \\
\text { (see fig. 4) }\end{array}$ & $\begin{array}{l}\text { NOAA NWS } \\
\text { station number } \\
\text { (tNWSCoopID) }\end{array}$ & $\begin{array}{l}\text { NOAA NWS station name } \\
\text { (tNWSStationName) }\end{array}$ & $\begin{array}{c}\text { Latitude, } \\
\text { in decimal } \\
\text { degrees } \\
\text { (dLatitude) }\end{array}$ & $\begin{array}{l}\text { Longitude, } \\
\text { in decimal } \\
\text { degrees } \\
\text { (dLongitude) }\end{array}$ & $\begin{array}{l}\text { Station location } \\
\text { elevation, in } \\
\text { feet above } \\
\text { mean sea level } \\
\text { (sStationElev) }\end{array}$ & $\begin{array}{c}\text { Begin } \\
\text { POR year } \\
\text { (IStartYear) }\end{array}$ & $\begin{array}{c}\text { End POR } \\
\text { year } \\
\text { (IEndYear) }\end{array}$ \\
\hline \multicolumn{8}{|c|}{ Georgia } \\
\hline 1138 & 91619 & CARNESVILLE $4 \mathrm{~N}$ & 34.450000 & -83.250000 & 866 & 1965 & 2009 \\
\hline 1148 & 91998 & CLERMONT 4 WSW & 34.450000 & -83.850000 & 1,281 & 1965 & 2007 \\
\hline 1153 & 92479 & DAHLONEGA 3 NNW & 34.583333 & -84.166667 & 1,382 & 1970 & 2008 \\
\hline 1156 & 92578 & DAWSONVILLE & 34.416667 & -84.116667 & 1,343 & 1965 & 2003 \\
\hline 1175 & 94651 & JASPER & 34.450000 & -84.450000 & 1,550 & 1965 & 2002 \\
\hline 1179 & 94688 & JOHNTOWN & 34.550000 & -84.250000 & 1,310 & 1965 & 1997 \\
\hline 3537 & 310301 & ASHEVILLE & 35.600000 & -82.533333 & 2,238 & 1965 & 2009 \\
\hline 3538 & 310312 & ASHFORD & 35.883333 & -81.950000 & 1,790 & 1965 & 2009 \\
\hline 3540 & 310438 & BADIN & 35.459000 & -80.182700 & 600 & 1965 & 2009 \\
\hline 3544 & 310750 & B EVERETT JORDAN DAM & 35.650000 & -79.066667 & 310 & 1978 & 2009 \\
\hline 3552 & 311241 & BURLINGTON & 36.096000 & -79.401000 & 640 & 1965 & 2009 \\
\hline 3553 & 311458 & CAPE HATTERAS AP & 35.233000 & -75.621900 & 11 & 1965 & 2009 \\
\hline 3554 & 311515 & CARTHAGE WTP & 35.333333 & -79.400000 & 440 & 1965 & 2009 \\
\hline 3556 & 311564 & CATALOOCHEE & 35.616667 & -83.100000 & 2,650 & 1965 & 1989 \\
\hline 3560 & 311690 & CHARLOTTE DOUGLAS AP & 35.216667 & -80.950000 & 728 & 1965 & 2009 \\
\hline 3563 & 311881 & CLINTON 2 NE & 35.016667 & -78.283333 & 158 & 1971 & 2009 \\
\hline 3566 & 312230 & DALTON & 36.300000 & -80.400000 & 1,010 & 1965 & 1999 \\
\hline 3582 & 313638 & GREENVILLE & 35.633333 & -77.400000 & 32 & 1965 & 2009 \\
\hline 3587 & 313957 & HELTON & 36.550000 & -81.500000 & 2,840 & 1965 & 2009 \\
\hline 3590 & 314136 & HOBUCKEN & 35.233333 & -76.600000 & 8 & 1965 & 2007 \\
\hline 3594 & 314764 & LAKE LURE 2 & 35.433333 & -82.233333 & 1,040 & 1965 & 2009 \\
\hline 3596 & 314860 & LAURINBURG & 34.750000 & -79.450000 & 210 & 1965 & 2009 \\
\hline 3597 & 314970 & LEXINGTON & 35.850000 & -80.266667 & 760 & 1979 & 2009 \\
\hline 3605 & 315814 & MOORESVILLE 2 WNW & 35.600000 & -80.833333 & 870 & 1965 & 2009 \\
\hline 3606 & 315830 & MOREHEAD CITY 2 WNW & 34.733333 & -76.733333 & 10 & 1965 & 2009 \\
\hline 3611 & 315945 & MOUNT PLEASANT & 35.416667 & -80.433333 & 740 & 1965 & 2009 \\
\hline 3618 & 316261 & N WILKESBORO 11 SE & 36.083333 & -80.983333 & 1,050 & 1965 & 2005 \\
\hline 3621 & 316867 & POLKTON 2 NE & 35.016667 & -80.183333 & 305 & 1965 & 2005 \\
\hline
\end{tabular}


Table 1. Summary of site attributes for 92 selected National Oceanic and Atmospheric Administration (NOAA) National Weather Service (NWS) hourly precipitation stations within and near North Carolina.-Continued

[Site attributes are from Granato (2010). Precipitation stations outside of North Carolina were selected by using a geographic information system overlay of Parameter-elevation Regressions on Independent Slopes Model map of average annual precipitation in and near North Carolina. For cross reference, field names shown in parentheses are from the national Stochastic Empirical Loading and Dilution Model precipitation dataset (Granato, 2010). POR, period of record]

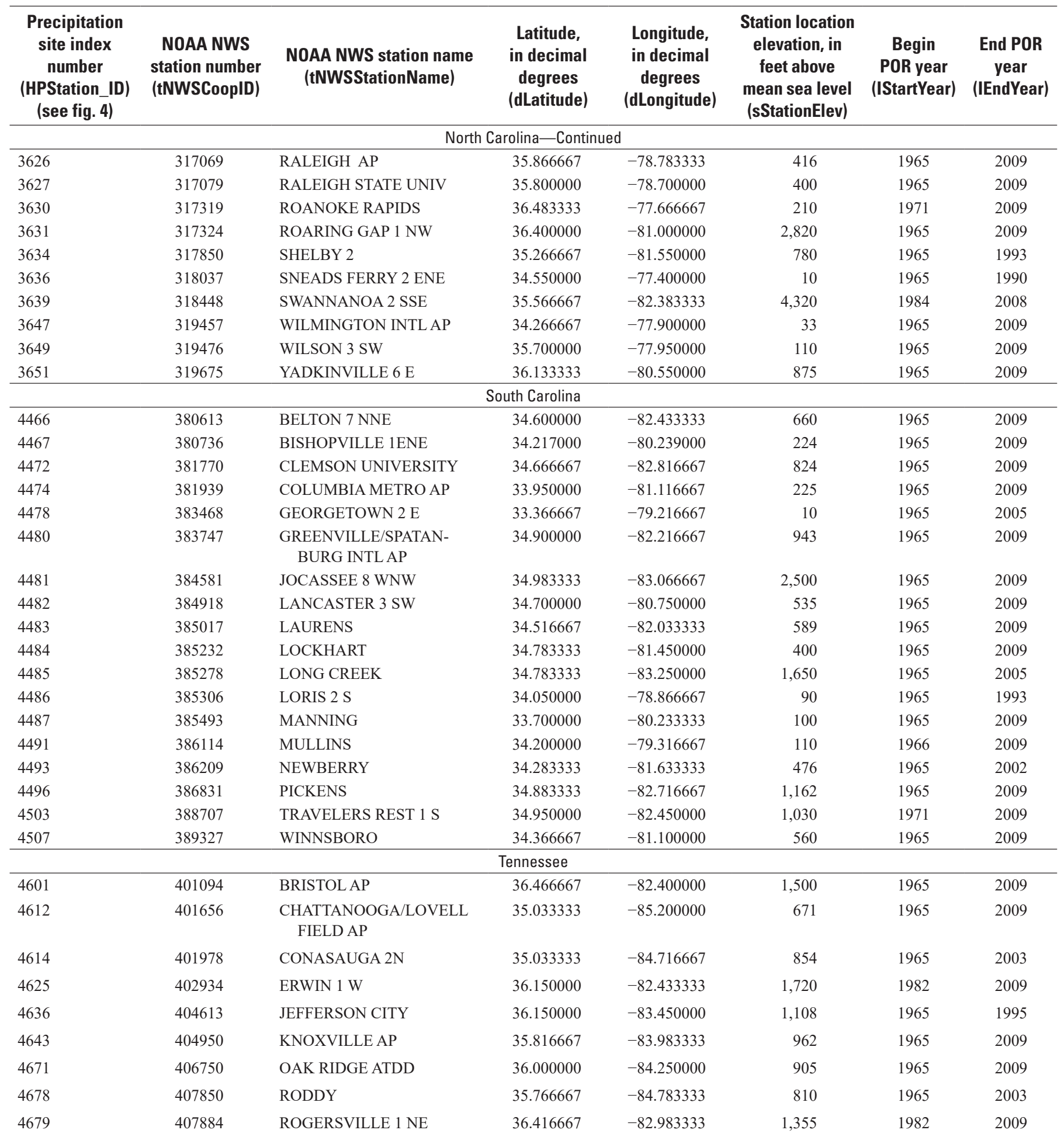


Table 1. Summary of site attributes for 92 selected National Oceanic and Atmospheric Administration (NOAA) National Weather Service (NWS) hourly precipitation stations within and near North Carolina._Continued

[Site attributes are from Granato (2010). Precipitation stations outside of North Carolina were selected by using a geographic information system overlay of Parameter-elevation Regressions on Independent Slopes Model map of average annual precipitation in and near North Carolina. For cross reference, field names shown in parentheses are from the national Stochastic Empirical Loading and Dilution Model precipitation dataset (Granato, 2010). POR, period of record]

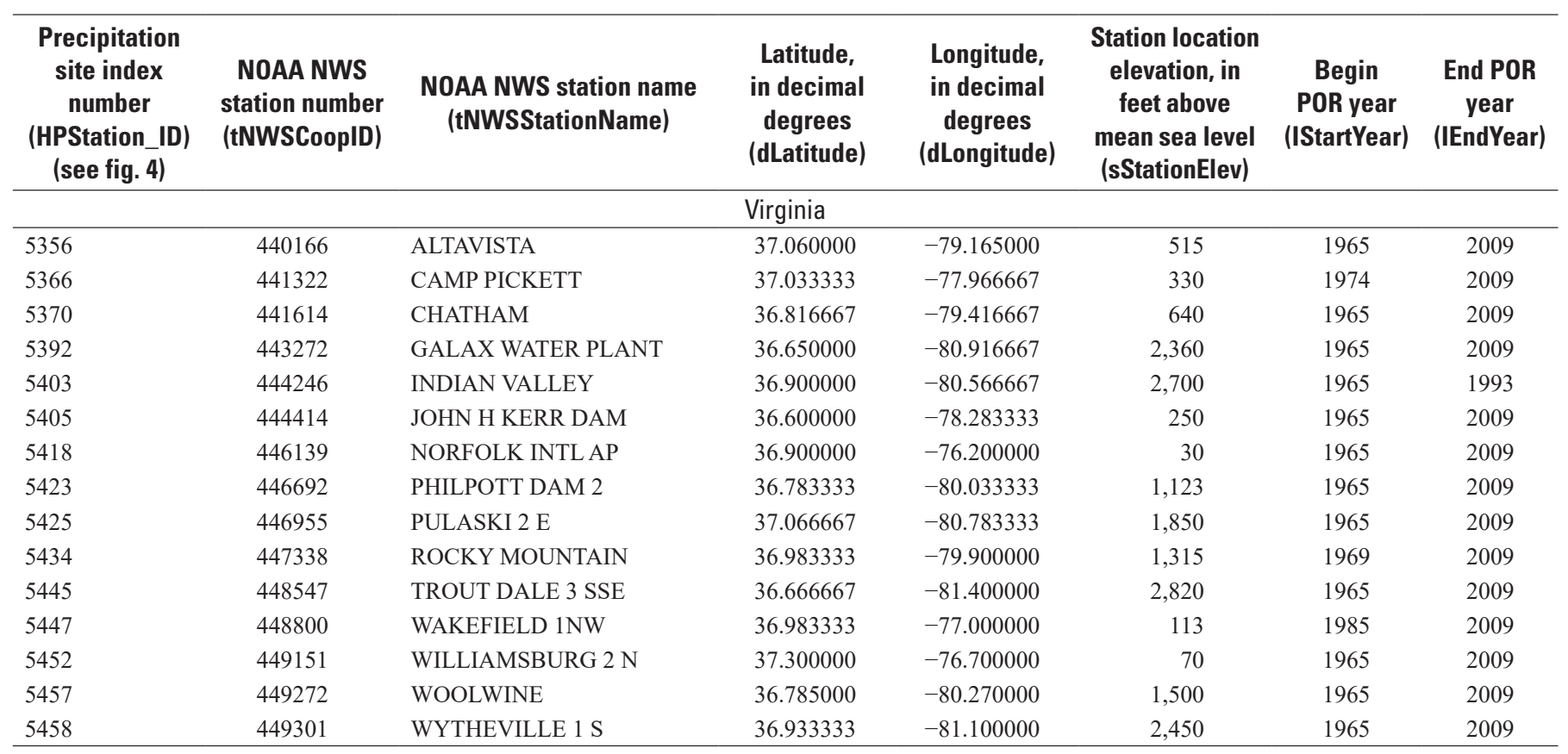




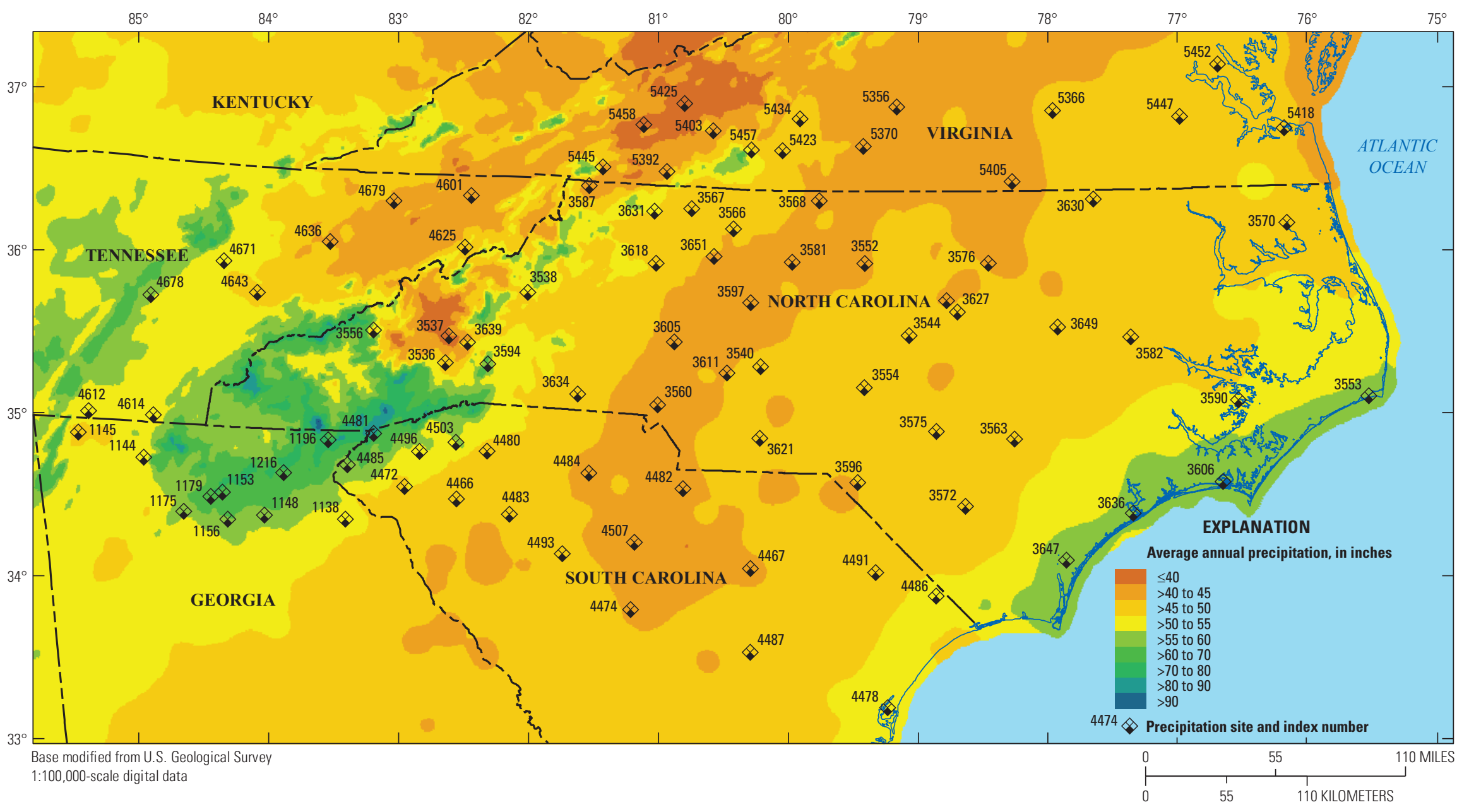

Figure 3. Map showing 92 selected National Oceanic and Atmospheric Administration National Weather Service hourly precipitation stations within and near North Carolina and Parameter-elevation Regressions on Independent Slopes Model average annual precipitation for 1981-2010. 
While developing the national precipitation dataset, Granato (2010) compared precipitation statistics for 129 stations common to two separate datasets, the first for the 1949-87 period (compiled by Driscoll, Palhegyi, and others, 1989) and the second for the 1965-2006 period. Scatterplot diagrams for four precipitation statistics (Granato, 2010, fig. 18, p. 51) indicated variations in values among the stations, but the two datasets were found to have comparable values for most stations. The medians of the percent differences in individual paired-station statistics between the datasets were about 0.0 , $0.67,-0.48,1.4$, and 0.64 percent for the number of storm events per year, the annual precipitation, storm-event volume, storm-event duration, and the time between storm-event midpoints, respectively. Correlation coefficients between statistics for the 129 stations common to both datasets were 0.99 for the number of storm events per year, the annual precipitation volume, and the storm-event precipitation volume; 0.98 for the time between storm-event midpoints; and about 0.94 for the storm-event duration (Granato, 2010). The similarity of values for most stations common between the two datasets suggests no substantial changes in the long-term precipitation statistics between the two periods of record. On the basis of these comparisons, as well as similar findings in a precipitation frequency study for Mecklenburg County, North Carolina, that suggested little change in long-term statistical values (Weaver, 2006), it was determined that addition of 4 to 6 years of NOAA hourly precipitation records beyond 2009 (up to 2013 or 2015) would not yield sufficient benefits to warrant the efforts needed to convert data to the legacy format required by the computer programs.

Regional precipitation statistics are used for a level-one SELDM analysis, but precipitation statistics can vary substantially within each region (Granato, 2010). A level-two analysis can use statistics from one or more nearby precipitation data stations, but the closest precipitation station may not be representative of conditions at the site of interest (Granato 2010, 2013). For example, a highway site near the edge of the Piedmont ecoregion may be closest to a precipitation station in the mountainous Blue Ridge ecoregion but may be best represented by precipitation statistics from a more distant station that is more hydrologically similar than the nearby site in mountainous terrain. Therefore, the Parameter-elevation Regressions on Independent Slopes Model (PRISM) average annual precipitation dataset (PRISM Climate Group, 2016) was adopted as a qualitative visual guide (fig. 3 ) to help SELDM users identify areas of hydrologic similarity and select representative precipitation stations for a site of interest.

The PRISM dataset is used as a qualitative guide because an attempt to identify quantitative relations between the PRISM dataset and the required precipitation statistics did not produce any such relations. The PRISM annual and monthly average precipitation data (1981-2010) at 800-meter resolution were downloaded and processed into geographic information system (GIS) layers and were then overlaid by an initial and provisional subset of 114 NOAA stations in the national precipitation dataset. The elevation, longitude, and latitude of the 114 NOAA sites were compiled along with average annual precipitation values extracted from the PRISM layer. Statistical analyses and exploratory regression analyses were completed to find a suitable relation for estimating the three SELDM precipitation statistics (average storm-event volume, storm-event duration, and time between storm events). Only the average storm-event volume statistic had a semi-strong correlation (R-square value of about 0.7 ), but this relation was not predictive enough for further analysis and publication in this report. Although quantitative statistical relations are not available from the current study, the PRISM map in figure 3 may be used to evaluate selection of nearby precipitation monitoring stations (table 1) for a level-two analysis on the basis of hydrologic similarity.

\section{Prestorm Streamflow Statistics}

In SELDM, the prestorm flow is a primary component of the total upstream stormflow in many simulated events (fig. 2) (Granato, 2013, Risley and Granato, 2014). Prestorm streamflow represents the flow rate of water in the stream at the beginning of runoff; this flow may represent base flow and residual flows from preceding storms (Granato, 2010, 2013). The storm-event hydrograph is superimposed on this flow. SELDM calculates prestorm streamflow volume from the basin upstream from the highway-runoff mixing point for each storm as a stochastic variable. Prestorm streamflow is defined by the average, standard deviation, and skew of the logarithms of nonzero daily-mean streamflows and the proportion of zeroflow days in the record of the upstream basin. Granato (2010) provided a detailed discussion of the methods and data used for estimating prestorm streamflows for use with SELDM. The national SELDM streamflow database includes prestorm flow statistics from 2,873 selected USGS streamgages across the United States with at least 20 years of record during the period from 1960 to 2004 (Granato, 2013). Each of these streamgages is associated with the underlying EPA Level III ecoregion for use in developing regional level-one estimates.

Developing level-one, -two, or -three estimates of prestorm streamflow at any site is facilitated by the USGS long-term streamflow gaging program. Nationally, the USGS has an extensive streamgage network with more than 20,000 current or historic streamgages (Granato and others, 2017). The streamflow statistics for 18,122 of these streamgages that had 3 or more years of record are stored in StreamStatsDB and are available in StreamStats for use with other applications. The USGS National Water Information System contains streamflow measurements for many more active and inactive surface-water sites that can be used to estimate long-term statistics by using standard methods (Granato, 2009). To develop level-one analyses, SELDM users can select prestorm flow statistics by ecoregion. To develop level-two analyses, SELDM users can select prestorm flow statistics for nearby hydrologically similar sites within the model or enter statistics from selected sites with the user-defined option. To develop a 
level-three prestorm flow analysis, users can establish a shortterm or partial record station at the site of interest and use a long-term index gage to estimate statistics at the site of interest.

SELDM uses the statistics for the logarithms of nonzero daily-mean streamflows and the proportion of zero-flow days to generate the prestorm flows. SELDM has data-entry fields for the arithmetic streamflow statistics, 7-day 10-year low-flow (7Q10) discharge, 1-day 3-year biological flow (1B3), and 4-day 3-year biological flow (4B3). The 7Q10 discharge is defined as the threshold at which the annual minimum average streamflow for a 7-consecutive-day period is equal to or lower than, on average, once every 10 years. For the North Carolinaenhanced SELDM, the published 7Q10 discharges based on the most recent statewide low-flow update (Weaver, 2016) were compiled for 266 streamgages across North Carolina. The 1B3 and 4B3 flows are biologically based design flows used by the EPA as water-quality criteria to protect aquatic life (U.S. Environmental Protection Agency, 1986). The 1B3 and 4B3 flows are defined as 1-day and 4-day average flows, respectively, that drop below the design flow, on average, no more than once every 3 years. The $1 \mathrm{~B} 3$ and $4 \mathrm{~B} 3$ flow statistics were compiled for 204 of the 266 streamgages where 20 or more years of record were available through the 2015 water year. These statistics are not required input for SELDM analyses but are included to evaluate the hydrologic similarity of potential index sites and to help identify the potential effects of water-use withdrawals or discharges.

Weaver (2016) documented the low-flow characteristics and flow-duration statistics for 266 selected U.S. Geological Survey streamgages across North Carolina. For the North Carolina-enhanced SELDM, the streamflow statistics were calculated for the same group of 266 continuous-record streamgages (fig. 4). The periods of record for the SELDM streamflow statistics were identical to those used in the low-flow update but were extended through the 2015 water year where data were available. The use of starting period of record consistent with the period of record used for the updated low-flow and flow-duration statistics (Weaver, 2016) is pertinent for streamgages affected by regulated flows.

The SELDM streamflow statistics were calculated using the Get National Water Information System Streamflow (Q) (GNWISQ) and Streamflow (Q) Statistics (QSTATS) computer programs developed and described by Granato (2009, appendixes 1 and 4). The GNWISQ program was developed to guide users in downloading and reformatting National Water Information System (NWIS) streamflow data from the online USGS portal. The QSTATS program facilitates statistical analysis of daily mean discharge records, with emphasis on the computation of statistics for use in SELDM. Users should refer to appendixes 1 and 4 in Granato (2009) for further descriptions and interpretations of the statistics generated by the QSTATS program.

The group of 266 North Carolina streamgages includes 177 unregulated sites, 56 regulated sites, and 33 sites known or considered to be affected by varying degrees of minor regulation and (or) diversions upstream from the streamgages. Regulated streamflows are commonly attributed to flow releases at upstream reservoirs that are operated to provide flood control and to augment downstream low flows. Diversions are attributed to water-supply withdrawals from streams or pointsource discharges into streams upstream from the streamgage.

Among these 266 sites are 5 sites where discharge records were combined with those from a nearby streamgage on the same stream to provide a longer POR for the flow statistics (Weaver, 2016). These sites are (1) unregulated station (sta.) 0208521324 (paired with discontinued sta. 02085220), (2) regulated sta. 02096960 (paired with discontinued sta. 02097000), (3) regulated sta. 03505550 (paired with discontinued sta. 03505500), (4) regulated sta. 03508050 (paired with discontinued sta. 03508000), and (5) regulated sta. 03510577 (paired with discontinued sta. 03510500).

Comparisons were made for eight selected streamflow statistics at 84 streamgages across North Carolina that are concurrent in both the national SELDM and North Carolinaenhanced SELDM streamflow databases (table 2, retransformed $\log 10$ comparisons shown in fig. 5). These comparisons were made by computing the percentage change of the updated North Carolina statistics relative to the national statistics. Six of the eight median percent changes were negative. The median percent changes for all eight statistics were less than or equal to an absolute value of 4 percent (table 2).

In the most recent statewide low-flow compilation for North Carolina streams, Weaver (2016) documented a decline in the 7Q10 discharges between the 1998 and 2011 climatic years, with the median percentage change being -18 percent. The period between 2004 (latest water year in the national SELDM database) and 2015 (latest water year in the North Carolina SELDM database) is roughly comparable to the 1998-2011 period investigated in the low-flow study (Weaver, 2016). The occurrence of negative percentage changes for the mean and median statistics is consistent with the observation of lower 7Q10 discharges between 1998 and 2011 (Weaver, 2016), lending additional support to the possibility of a recent decline in streamflow across North Carolina.

The updated streamflow statistics for the 177 unregulated sites were pre-loaded into the North Carolina-enhanced SELDM, where they can be accessed for site selection on the Streamflow statistics input panel. Available under the "NC SELDM" database name, users can select one or more of the 177 unregulated sites for use in completing SELDM streamflow analyses. Each of these 177 streamgages were associated with the underlying EPA Level III ecoregion for use in developing regional level-one estimates.

In SELDM, the default is to use prestorm flows based on streamgages without substantial regulation or diversions to assess the potential effects of runoff on natural streams. However, sites of interest may be located on streams with a substantial amount of regulation, water withdrawals, or major point-source discharges. Streamflow statistics for 56 regulated sites and 33 sites affected by minor regulation and (or) upstream diversions were calculated and are available in (1) the USGS data release that accompanies the current study (Weaver and others, 2019) and (2) the USGS online StreamStats database application. 


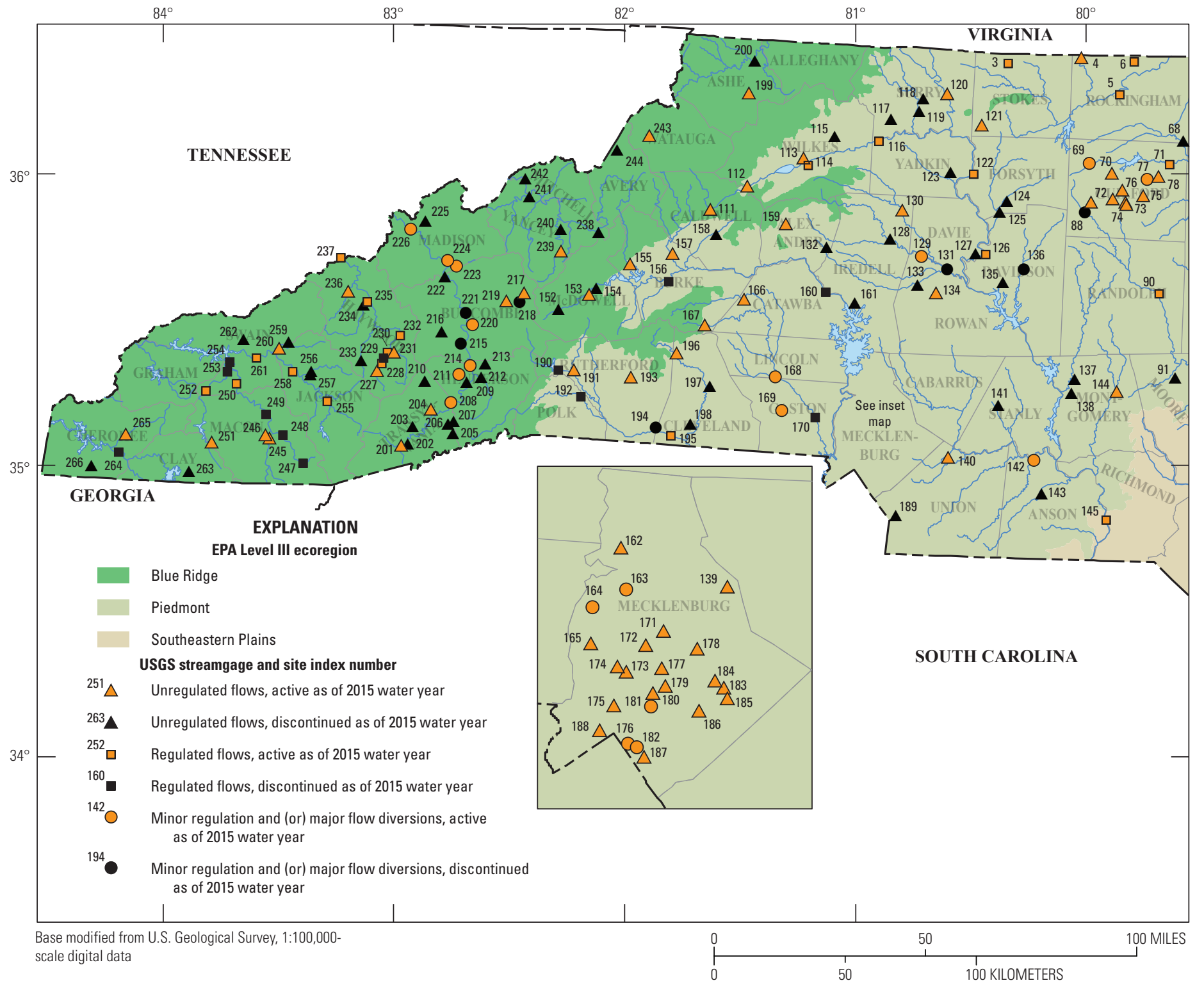

Figure 4. Map showing 266 selected U.S. Geological Survey (USGS) continuous-record streamgages in western and eastern North Carolina used to determine prestorm streamflow statistics for the North Carolina Stochastic Empirical Loading and Dilution Model study. EPA, U.S. Environmental Protection Agency. 


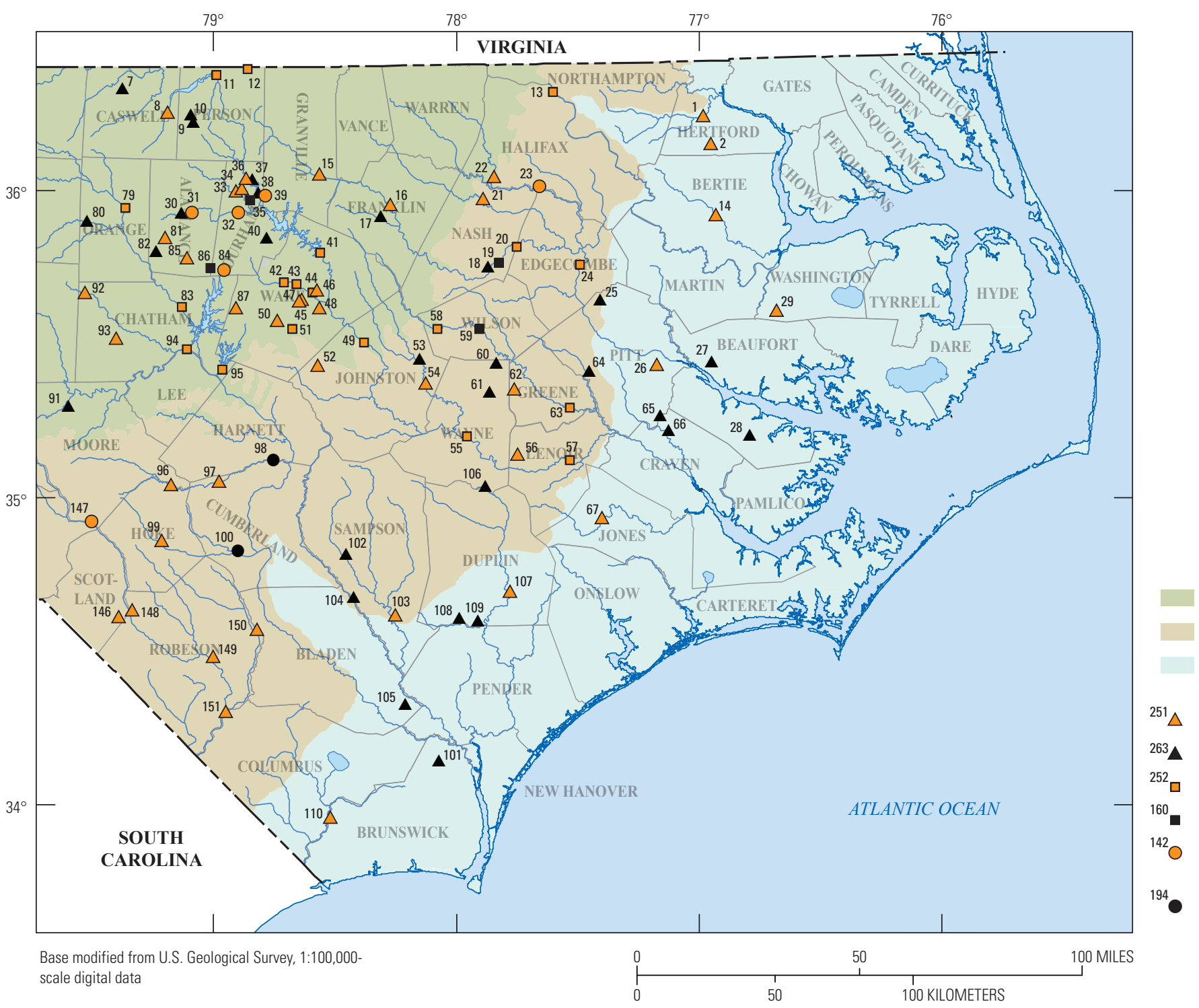

\section{EXPLANATION}

\section{EPA Level III ecoregion}

Piedmont

Southeastern Plains

Middle Atlantic Coastal Plain

USGS streamgage and site index number

${ }^{251} \triangle \quad$ Unregulated flows, active as of 2015 water year

263 Unregulated flows, discontinued as of 2015 water year

口 Regulated flows, active as of 2015 water year

160 Regulated flows, discontinued as of 2015 water year

${ }^{42} \mathrm{O}$ Minor regulation and (or) major flow diversions, active as of 2015 water year

Minor regulation and (or) major flow diversions, discontinued as of 2015 water year

Figure 4. Map showing 266 selected U.S. Geological Survey (USGS) continuous-record streamgages in western and eastern North Carolina used to determine prestorm streamflow statistics for the North Carolina Stochastic Empirical Loading and Dilution Model study. EPA, U.S. Environmental Protection Agency.-Continued 


\section{Assessing Water Quality From Highway Runoff at Selected Sites in North Carolina with SELDM}

Table 2. Median percentage change of selected streamflow statistics for 84 U.S. Geological Survey streamgages in North Carolina that are concurrent in the national Stochastic Empirical Loading and Dilution Model (SELDM) and updated North Carolina SELDM databases.

[Percentage change was determined by comparison of updated North Carolina SELDM streamflow statistics relative to national SELDM streamflow statistics. $\left(\mathrm{ft}^{3} / \mathrm{s}\right) / \mathrm{mi}^{2}$, cubic feet per second per square mile]

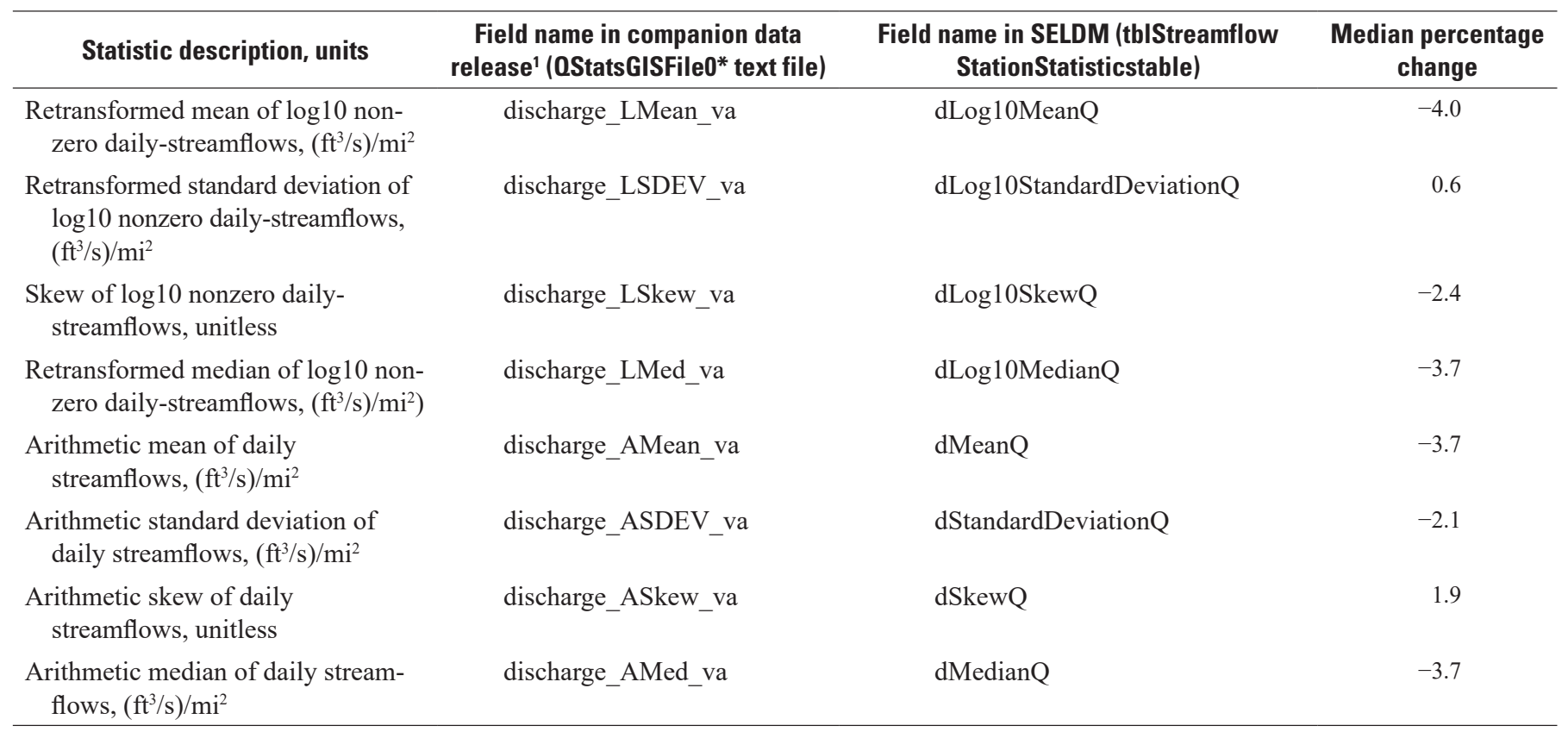

${ }^{1}$ Weaver and others (2019). 

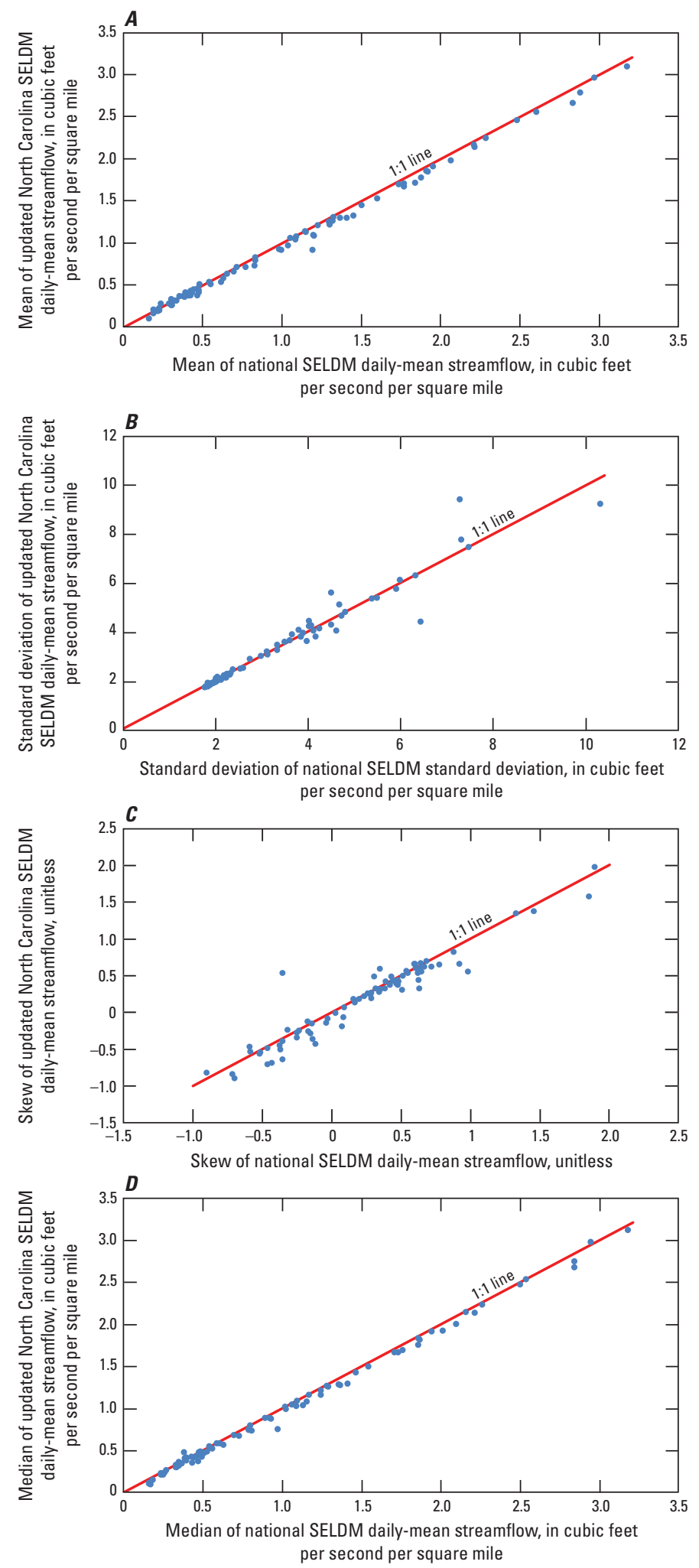

Figure 5. Graphs showing relations between national Stochastic Empirical Loading and Dilution Model (SELDM) and updated North Carolina SELDM retransformed log10 streamflow statistics for 84 U.S. Geological Survey streamgages across North Carolina that are concurrent in the national SELDM and updated North Carolina SELDM databases: $(A)$ mean, $(B)$ standard deviation, $(C)$ skew, and $(D)$ median of daily-mean streamflow. 
Similar to the national streamflow statistics update completed by Granato and others (2017), the streamflow statistics computed for the 266 streamgages in the North Carolina-enhanced SELDM were updated in the StreamStatsDB, which is a database accessible through the online StreamStats application at https://streamstats.usgs.gov/ss/. The StreamStatsDB contains selected basin characteristics and streamflow information for USGS streamgages in North Carolina and can be accessed through the StreamStats Data-Collection Station Report pages within the StreamStats application (fig. 6).

Within a StreamStats Data-Collection Station Report, users can locate (1) the fraction of daily-mean streamflows recorded as zero flow and (2) three of the four flow statistics used by SELDM to estimate the prestorm streamflows. As previously discussed, these variables are required inputs for the SELDM streamflow statistics. The fraction of zero-flow daily-mean streamflows is provided under the "Probability_flow_durations_are_zero" field in the station report. The three streamflow statistics (in $\log 10$ transformation) available from the station report are the average ("Mean_of_Logs_of_Daily_Values" field), standard deviation ("Std_Dev_of_Logs_of_Daily_Values" field), and skew ("Skew_of_Logs_of_Daily_Values" field). In SELDM, these variables can be entered in the "Streamflow Statistics" input panel using the "User-Defined" option under a "New Definition" entry.

\section{Runoff Coefficient Statistics}

SELDM uses runoff coefficient statistics as the basis for the stochastic generation of runoff flows from the highway site and the upstream basin (Granato, 2010, 2013). Runoff coefficients are calculated by dividing the total storm runoff (in watershed inches) by the basin-average precipitation (in inches) during a storm event. Runoff coefficients are used with SELDM because it is a lumped-parameter, event-based model that does not calculate the spatial distribution of

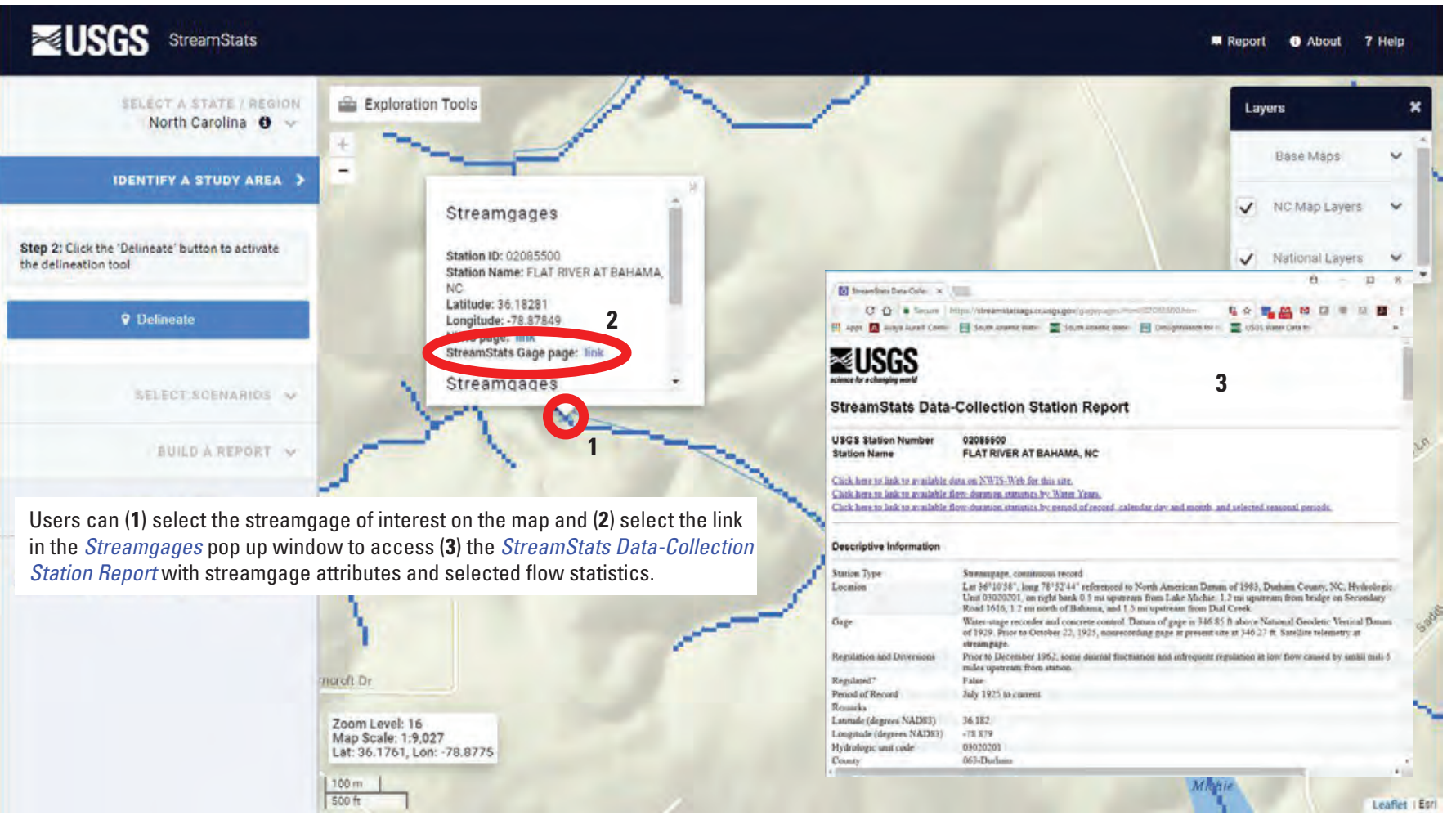

Figure 6. Screenshots of the U.S. Geological Survey StreamStats application showing the Streamgages pop-up window and StreamStats Data-Collection Station Report where updated streamflow statistics computed for the North Carolina-enhanced Stochastic Empirical Loading and Dilution Model can be accessed. 
precipitation and stormflow generation. In SELDM, runoff coefficient statistics are calculated as a function of the total impervious area of the highway site or the upstream basin using regression equations. For the national SELDM, the regression equations for highway sites were developed with rainfall-runoff data from 58 highway basins across the country, and the regression equations for upstream basins were developed with data from 167 basins across the country with various nonhighway land uses (Granato, 2013). The highway-runoff coefficients are correlated to the upstream runoff coefficients as a function of the imperviousness of each area (Granato, 2013). SELDM users may select from the predefined SELDM statistics or the National Urban Runoff Program relations or enter their own runoff coefficient statistics.

Granato (2010) compiled regression equations relating the average runoff coefficient to the total impervious fraction from seven published studies. The average runoff coefficient values associated with an impervious fraction of 1 ranged from 0.67 to 0.923 with a median estimate of 0.821 among the six studies done in the United States. Granato (2013) developed regression models for estimating the average, standard deviation, and skew coefficient of highway-site runoff coefficients with data from 58 selected highwayrunoff monitoring sites (table 3). Similarly, Granato (2010) developed regression models for estimating the average, standard deviation, and skew coefficient of upstream-basin runoff coefficients with data from 167 selected nonhighwayrunoff monitoring sites (table 3). The maximum-predicted average runoff coefficient values for the highway and upstream basin (nonhighway) equations were 0.785 and 0.769 , respectively. Granato (2010) compared the estimates to data from 6,142 storm events at 306 study sites and used processbased research to validate the regression results. Although an average runoff coefficient from a completely impervious surface is commonly expected to be 1 , field studies have shown that evaporation and infiltration from paved surfaces may have mean values in the range from about 20 to more than 30 percent over many storms (Mansell and Rollet, 2006; Ramier and others, 2006; Wiles and Sharp, 2008; Wanielista and others, 2010).

In the current study, data from 17 selected highwayrunoff monitoring sites in North Carolina with impervious fractions ranging from 0.22 to 1 were used to calculate average runoff coefficients for each site and to develop a regression relation between the impervious fractions and average runoff coefficients (table 3 ). These data also were combined with the Granato (2010) dataset to calculate a new regression relation (fig. 7). For comparison, the upper and lower 95-pecent confidence limit values were calculated for the slope and intercept of the equations developed for the current study and for the high-impervious, nonhighway equation developed by Granato (2010). The regression equations and the 95-percent confidence limit values of the slope were calculated by using the Kendall-Thiel Robust Line computer program (Granato, 2006). The 95-percent confidence limit values for the intercept were calculated by using confidence intervals for the median described by McGill and others (1978) and the confidence intervals of the slope.

This analysis indicates that neither the slopes nor the intercepts of the four equations compared in table 3 are statistically different at the 95-percent confidence interval. However, there are substantial differences in estimates of the average runoff coefficient for completely impervious sites (table 3 ). The estimated average runoff coefficient value from the North Carolina sites equation is only 0.628 , which is less than estimates from other commonly used equations (Granato, 2010) and less than would be predicted by field studies on evaporation and infiltration from paved surfaces (Mansell and Rollet, 2006; Ramier and others, 2006; Wiles and Sharp, 2008; Wanielista and others, 2010). The estimated average runoff coefficient value from the regression equation for the combined dataset also is biased low (fig. 7).

The highway-runoff research studies conducted by universities in North Carolina had varying degrees of quality assurance and quality control for drainage area delineations and flow measurements (see subsequent "Simulating Highway-Runoff Quality" section for discussion and study references). SELDM was developed in coordination with the FHWA, the EPA, State departments of transportation, and several other land and water-management agencies (Granato, 2013); overly optimistic estimates of average runoff coefficient values in SELDM could raise future regulatory challenges. Therefore, the North Carolina data will not be used to update the runoff coefficient equations for the North Carolina-enhanced SELDM at this time.

\section{Recession Ratio Statistics}

For runoff-quality modeling, information about the timing of runoff from a site of interest and from the basin upstream from the stormflow outfall is necessary to estimate the quantity of the upstream flow that occurs concurrently with runoff from the site of interest. Because the duration of highway runoff, BMP discharges, and upstream stormflows may be disparate, SELDM solves the mass-balance equations by using concurrent stormflows (Granato, 2012, 2013, 2014). The timing of stormflows from the highway and upstream basin are calculated by using a triangular hydrograph for each storm that is a function of the storm duration, the hydrograph recession ratio, and the basin lagtime. The hydrograph recession ratio is calculated as the duration of the falling limb of the hydrograph divided by the duration of the rising limb of the hydrograph. 
Table 3. Statistics used to estimate the confidence intervals of the average runoff coefficient equations.

[For the two-segment upstream-basin (high-impervious, nonhighway) equation, an input breakpoint of 0.614 results in a high-impervious equation-breakpoint impervious-fraction of 0.55 . Regression equations and 95-percent confidence limit values for the slope were calculated by using the Kendall-Thiel Robust Line computer program (Granato, 2006). The 95-percent confidence limit values for the intercept were calculated by using confidence intervals for the median described by McGill and others (1978) and the confidence intervals of the slope. Shaded cells indicate statistics associated with the default methods in the Stochastic Empirical Loading and Dilution Model (SELDM) that were used to compute the runoff coefficients for the highway site and upstream basin. LCLV, lower 95-percent confidence limit value; UCLV, upper 95-percent confidence limit value; MaxRv, calculated average runoff coefficient for an impervious fraction of 1]

\begin{tabular}{|c|c|c|c|c|c|c|c|c|}
\hline \multirow{2}{*}{ Dataset } & \multirow{2}{*}{$\begin{array}{c}\text { Number of } \\
\text { sites }\end{array}$} & \multicolumn{3}{|c|}{ Slope } & \multicolumn{3}{|c|}{ Intercept } & \multirow{2}{*}{ MaxRv } \\
\hline & & Median & LCLV & UCLV & Median & LCLV & UCLV & \\
\hline SELDM higway sites & 58 & 0.755 & 0.514 & 0.996 & 0.030 & -0.252 & 0.175 & 0.785 \\
\hline North Carolina highway sites & 17 & 0.791 & 0.541 & 1.03 & -0.162 & -0.430 & 0.015 & 0.628 \\
\hline $\begin{array}{l}\text { Combined SELDM and } \\
\text { North Carolina highway } \\
\text { sites }\end{array}$ & 75 & 0.775 & 0.603 & 0.942 & -0.092 & -0.246 & 0.049 & 0.683 \\
\hline SELDM upstream basins & 167 & 1.14 & 0.178 & 1.72 & -0.371 & -0.772 & 0.281 & 0.769 \\
\hline
\end{tabular}




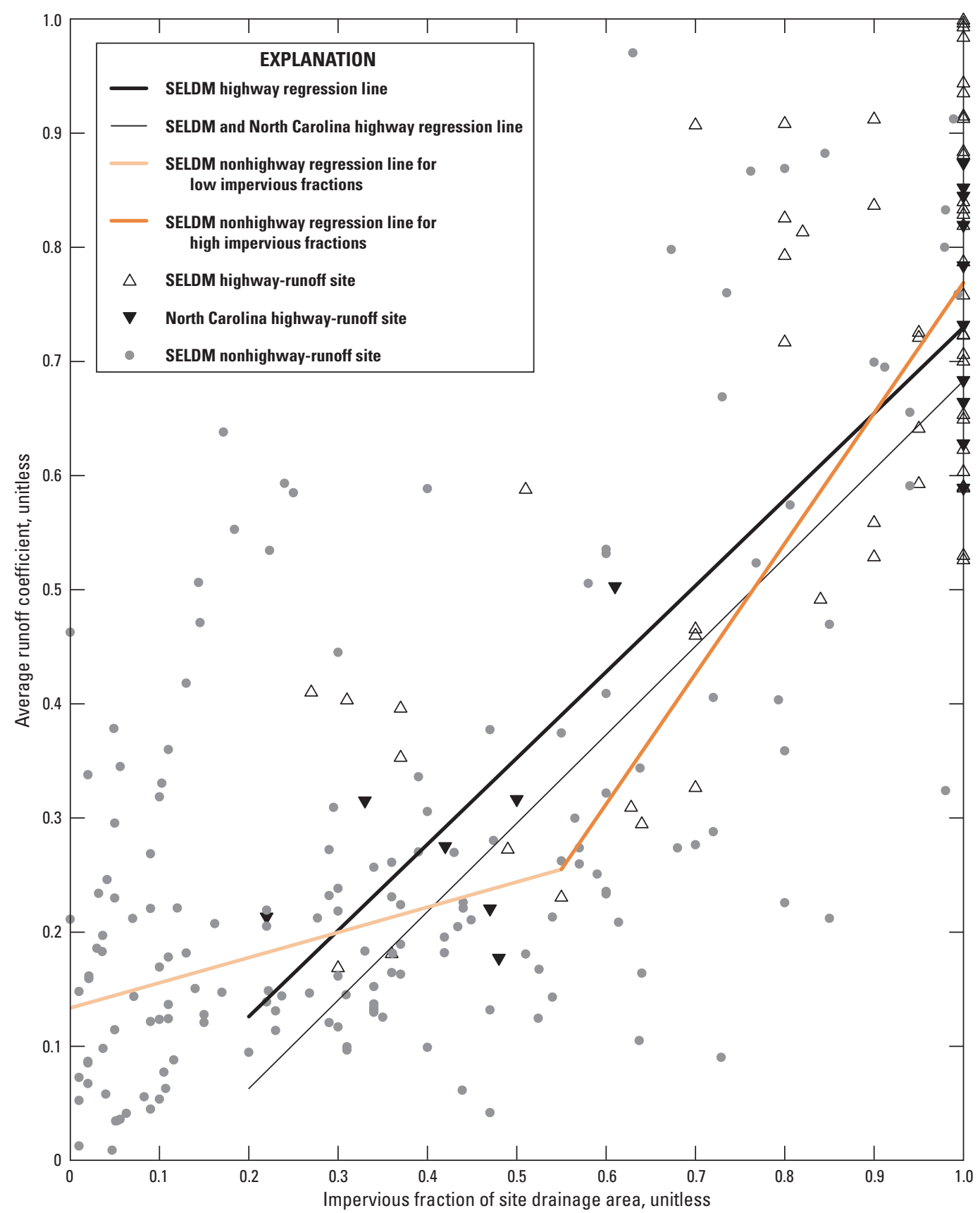

Figure 7. Graph showing the mean runoff coefficients for Stochastic Empirical Loading and Dilution Model (SELDM) and North Carolina highway- and nonhighway-runoff monitoring sites. The nonparametric regression lines indicate the relations between the average runoff coefficient and the impervious fraction in the respective drainage areas. 
The storm duration is a stochastic variable, which is calculated for each storm based on regional or local streamflow statistics. The hydrograph recession ratio is equal to 1 for the highway site but is a stochastic variable for the upstream basin. The basin lagtime, defined as the time between the centroid of precipitation and the centroid of runoff, commonly is modeled as a deterministic variable that depends on basin properties. Granato (2012) developed national basin lagtime equations as a function of main channel length, main channel slope, and imperviousness of the upstream basin or the basin development factor (BDF) by using data and basin lagtime information from 896 sites nationwide. The dataset included 122 sites located in and around North Carolina that are representative of the physiography and hydrology of the State. In the enhanced SELDM for North Carolina, the equation based on imperviousness of the upstream basin is used to define the basin lagtime for simulated sites.

SELDM uses hydrograph recession ratios along with basin lagtimes to simulate the timing of flow from the highway site and the upstream basin by using a triangular hydrograph (Granato, 2012, 2013). As is commonly done, basin lagtimes are simulated as constant properties of the watershed, but the time from the beginning of precipitation to the centroid of runoff is stochastic because the storm duration varies stochastically. The recession ratio for the highway site is always $1: 1$, as is used for the rational method equations for highly impervious basins (Granato, 2010, 2013). The hydrograph recession ratio for the upstream basin, however, is treated as a stochastic variable that varies from storm to storm.

Granato (2012) used least-squares optimization techniques with measured runoff hydrographs from 41 streamgages across the United States for the national SELDM. This group of streamgages included 32 basins in Massachusetts and 9 basins in other States, including 2 sites in North Carolina (USGS sta. 02146409 and USGS sta. 02146700). In that study, the minimum values of recession ratios among the 41 streamgages ranged from 1.0 to 1.77 with a median of 1.02 . The most probable values of recession ratios ranged from 1.0 to 3.52 with a median of 1.85 , and the maximum values ranged from 2.66 to 11.3 with a median of 4.36 .

In the North Carolina SELDM enhancement, the optimization methods described by Granato (2012) were used by the USGS in cooperation with NCDOT engineers to fit hydrographs to the triangular distribution for 30 basins with drainage areas ranging from 4.12 to $63.3 \mathrm{mi}^{2}$ and impervious percentages ranging from 0.01 to 48.8 percent (table 4 ). The 30 streamgages provide a spatial distribution across North Carolina in the following EPA Level III ecoregions: Blue Ridge ( 9 rural basins), Piedmont (5 rural basins and 11 urban basins), Southeastern Plains (2 rural basins), and Middle Atlantic Coastal Plain (3 rural basins) (fig. 4).

The hydrograph statistics were calculated by using 22 or more selected storm-event (runoff) hydrographs from each of the basins. The selected hydrographs were obtained using instantaneous discharge records (commonly 15-minute intervals) available for the 1996-2015 water years (a period of 20 years). Using a fitting spreadsheet developed (and subsequently modified) for this analysis, the minimum recession ratio (minRR), most probable value recession ratio (mpvRR), and maximum recession ratio (maxRR) values were estimated for each of the 30 streamgages. In the North Carolina model enhancement, the minRR values for the 30 streamgages ranged from 1.0 to 1.43 with a median of 1.0. The mpvRR values ranged from 1.0 to 2.34 with a median of 1.07. The maxRR values ranged from 2.86 to 18.2 with a median of 4.72 . The fitted minRR and mpvRR values were commonly close to each other in magnitude and close to a value of 1 , as opposed to a larger spread between the two statistics for the 41 streamgages presented in Granato (2012). The smaller magnitudes of the median recession ratio statistics for the North Carolina SELDM enhancement relative to the national statistics are considered reflective of the overall smaller range in drainage areas of the streamgages. Additionally, given the urban characteristic of 11 of the 30 basins included in the North Carolina SELDM enhancement, it is possible that minimal storage exists in the basins, with runoff typically receding in a short amount of time, particularly relative to larger basins.

Granato (2012) used rank correlation analysis (Spearman's rho) to examine 19 commonly used explanatory variables and did not find any significant correlations for the minRR values. For the current North Carolina study, similar correlation analyses were completed to examine relations between the recession ratios and the basin characteristics available from the USGS StreamStats application for the 30 selected streamgages. The minRR values were found to be significantly correlated with 15 StreamStats characteristics consisting of 6 physical basin characteristics, 7 land cover characteristics, the percentage of basin located in hydrologic region 4 (a combination of the Southeastern Plains, Southern Coastal Plain, and Middle Atlantic Coastal Plain ecoregions; defined in Weaver and others, 2009), and the percentage of basin area with Hydrologic Soil Type D. The mpvRR values were found to be significantly correlated with the following three StreamStats characteristics: percentage of basin located in hydrologic region 4 (defined in Weaver and others, 2009), the 50 -year return interval for the maximum 24-hour precipitation, and the percentage of basin area with Hydrologic Soil Type D. The maxRR values were found to be significantly correlated with only one StreamStats land cover characteristic: percentage of National Land Cover Database 2001 barren land.

Comparison of the correlated characteristics across the three hydrograph recession ratio statistics did not reveal any concurrent characteristics nor any indication of meaningful characteristics that would explain the variation in the statistics. The correlations between the three hydrograph recession ratio statistics and the StreamStats basin characteristics were deemed to be statistical artifacts. Additionally, no significant correlations were identified between the three hydrograph recession ratio statistics and the drainage areas for the 30 selected streamgages. This conclusion is similar to that reached in the national study in which analyses of 
Table 4. Best-fit triangular-hydrograph recession ratios estimated from 22 or more storm-event hydrographs at 30 selected U.S. Geological Survey (USGS) continuousrecord streamgages in North Carolina.

[EPA, U.S. Environmental Protection Agency; minRR, minimum recession ratio; mpvRR, most probable value recession ratio; maxRR, maximum recession ratio; DRNAREA, drainage area in square miles (mi²); CSL10_85fm, main channel slope in feet per mile (ft/mi); LC11IMP, impervious area in percent from the 2011 National Land Cover Database]

\begin{tabular}{|c|c|c|c|c|c|c|c|c|c|}
\hline \multirow[b]{2}{*}{$\begin{array}{c}\text { Site } \\
\text { index } \\
\text { number } \\
\text { (fig. 4) }\end{array}$} & \multirow[b]{2}{*}{$\begin{array}{c}\text { USGS } \\
\text { streamgage } \\
\text { number }\end{array}$} & \multirow[b]{2}{*}{ Station name } & \multirow[b]{2}{*}{$\begin{array}{c}\text { EPA Level III ecoregion, } \\
\text { general basin } \\
\text { description }\end{array}$} & \multicolumn{3}{|c|}{ Hydrograph recession ratios } & \multicolumn{3}{|c|}{ Selected StreamStats basin characteristics } \\
\hline & & & & $\min R R$ & mpvRR & $\max R R$ & $\begin{array}{c}\text { Drainage area } \\
\text { (DRNAREA), } \\
\mathrm{mi}^{2}\end{array}$ & $\begin{array}{c}\text { Channel slope, } \\
\text { (CSL10_85fm), } \\
\mathrm{ft} / \mathrm{mi}\end{array}$ & $\begin{array}{c}\text { Impervious } \\
\text { area } \\
\text { (LC11IMP), } \\
\text { percent }\end{array}$ \\
\hline 2 & 02053500 & Ahoskie Creek at Ahoskie & $\begin{array}{c}\text { Middle Atlantic } \\
\text { Coastal Plain, rural }\end{array}$ & 1.219 & 1.298 & 5.095 & 63.3 & 2.53 & 0.75 \\
\hline 26 & 02084160 & $\begin{array}{l}\text { Chicod Creek at Secondary Road } \\
1760 \text { near Simpson }\end{array}$ & $\begin{array}{c}\text { Middle Atlantic } \\
\text { Coastal Plain, rural }\end{array}$ & 1.361 & 1.585 & 3.810 & 45 & 3.87 & 0.54 \\
\hline 29 & 02084557 & Van Swamp near Hoke & $\begin{array}{c}\text { Middle Atlantic } \\
\text { Coastal Plain, rural }\end{array}$ & 1.432 & 1.563 & 18.184 & 23 & 2.79 & 0.20 \\
\hline 34 & 0208524090 & $\begin{array}{l}\text { Mountain Creek at Secondary Road } \\
1617 \text { near Bahama }\end{array}$ & Piedmont, rural & 1.000 & 2.033 & 5.525 & 7.97 & 24.4 & 1.32 \\
\hline 46 & 0208732885 & Marsh Creek near New Hope & Piedmont, urban & 1.000 & 1.000 & 7.129 & 6.84 & 42.2 & 31.7 \\
\hline 48 & 02087359 & $\begin{array}{l}\text { Walnut Creek at Sunnybrooke Drive } \\
\text { at Raleigh }\end{array}$ & Piedmont, urban & 1.000 & 1.157 & 3.416 & 29.8 & 17.7 & 23.5 \\
\hline 50 & 02087580 & Swift Creek near Apex & Piedmont, urban & 1.059 & 1.202 & 6.714 & 21 & 23.0 & 17.2 \\
\hline 56 & 0208925200 & Bear Creek at Mays Store & Southeastern Plains, rural & 1.000 & 2.335 & 5.343 & 57.7 & 4.31 & 1.32 \\
\hline 74 & 02094775 & $\begin{array}{l}\text { Ryan Creek below U.S. } 220 \text { at } \\
\text { Greensboro }\end{array}$ & Piedmont, urban & 1.000 & 1.202 & 3.768 & 4.12 & 31.6 & 33.7 \\
\hline 75 & 02095000 & South Buffalo Creek near Greensboro & Piedmont, urban & 1.000 & 1.063 & 3.893 & 34 & 10.4 & 36.7 \\
\hline 76 & 02095181 & $\begin{array}{l}\text { North Buffalo Creek at Westover Ter- } \\
\text { race at Greensboro }\end{array}$ & Piedmont, urban & 1.000 & 1.000 & 4.758 & 9.55 & 28.0 & 28.5 \\
\hline 81 & 02096846 & Cane Creek near Orange Grove & Piedmont, rural & 1.000 & 1.000 & 4.689 & 7.54 & 24.5 & 0.31 \\
\hline 85 & 02097464 & Morgan Creek near White Cross & Piedmont, rural & 1.000 & 1.207 & 4.413 & 8.35 & 29.7 & 0.44 \\
\hline 89 & 02099000 & $\begin{array}{l}\text { East Fork Deep River near High } \\
\quad \text { Point }\end{array}$ & Piedmont, urban & 1.000 & 1.000 & 3.154 & 14.8 & 18.4 & 31.8 \\
\hline 92 & 0210166029 & $\begin{array}{l}\text { Rocky River near Crutchfield } \\
\text { Crossroads }\end{array}$ & Piedmont, rural & 1.000 & 1.000 & 6.767 & 7.42 & 20.3 & 4.57 \\
\hline 96 & 02102908 & Flat Creek near Inverness & Southeastern Plains, rural & 1.000 & 1.000 & 3.390 & 7.63 & 36.3 & 0.83 \\
\hline 111 & 02111000 & Yadkin River at Patterson & Blue Ridge, rural & 1.000 & 1.970 & 4.869 & 28.8 & 80.5 & 0.54 \\
\hline 112 & 02111180 & Elk Creek at Elkville & Blue Ridge, rural & 1.000 & 1.000 & 5.860 & 50.9 & 45.3 & 0.15 \\
\hline 121 & 02114450 & Little Yadkin River at Dalton & Piedmont, rural & 1.000 & 1.104 & 4.011 & 42.8 & 22.2 & 1.07 \\
\hline 139 & 0212414900 & $\begin{array}{l}\text { Mallard Creek below Stony Creek } \\
\text { near Harrisburg }\end{array}$ & Piedmont, urban & 1.000 & 1.000 & 2.857 & 34.6 & 21.7 & 20.7 \\
\hline 162 & 0214266000 & McDowell Creek near Charlotte & Piedmont, urban & 1.027 & 1.035 & 3.994 & 26.3 & 22.0 & 20.2 \\
\hline 173 & 02146300 & Irwin Creek near Charlotte & Piedmont, urban & 1.000 & 1.000 & 4.467 & 30.7 & 14.0 & 35.1 \\
\hline 177 & 02146409 & $\begin{array}{l}\text { Little Sugar Creek at Medical Center } \\
\text { Drive at Charlotte }\end{array}$ & Piedmont, urban & 1.000 & 1.000 & 8.093 & 11.8 & 20.8 & 48.8 \\
\hline
\end{tabular}


Table 4. Best-fit triangular-hydrograph recession ratios estimated from 22 or more storm-event hydrographs at 30 selected U.S. Geological Survey (USGS) continuousrecord streamgages in North Carolina.-Continued

[EPA, U.S. Environmental Protection Agency; minRR, minimum recession ratio; mpvRR, most probable value recession ratio; maxRR, maximum recession ratio; DRNAREA, drainage area in square miles (mi²); CSL10_85fm, main channel slope in feet per mile (ft/mi); LC11IMP, impervious area in percent from the 2011 National Land Cover Database]

\begin{tabular}{|c|c|c|c|c|c|c|c|c|c|}
\hline \multirow[b]{2}{*}{$\begin{array}{l}\text { Site } \\
\text { index } \\
\text { number } \\
\text { (fig. 4) }\end{array}$} & \multirow[b]{2}{*}{$\begin{array}{c}\text { USGS } \\
\text { streamgage } \\
\text { number }\end{array}$} & \multirow[b]{2}{*}{ Station name } & \multirow[b]{2}{*}{$\begin{array}{l}\text { EPA Level III ecoregion, } \\
\text { general basin } \\
\text { description }\end{array}$} & \multicolumn{3}{|c|}{ Hydrograph recession ratios } & \multicolumn{3}{|c|}{ Selected StreamStats basin characteristics } \\
\hline & & & & $\operatorname{minRR}$ & mpvRR & $\operatorname{maxRR}$ & $\begin{array}{c}\text { Drainage area } \\
\text { (DRNAREA), } \\
\mathrm{mi}^{2}\end{array}$ & $\begin{array}{c}\text { Channel slope, } \\
\text { (CSL10_85fm), } \\
\mathrm{ft} / \mathrm{mi}\end{array}$ & $\begin{array}{c}\text { Impervious } \\
\text { area } \\
\text { (LC11IMP), } \\
\text { percent }\end{array}$ \\
\hline 204 & 03441000 & Davidson River near Brevard & Blue Ridge, rural & 1.000 & 1.164 & 3.764 & 40.4 & 100 & 0.12 \\
\hline 217 & 0344894205 & $\begin{array}{l}\text { North Fork Swannanoa River near } \\
\text { Walkertown }\end{array}$ & Blue Ridge, rural & 1.000 & 1.069 & 5.577 & 14.5 & 450 & 0.14 \\
\hline 219 & 03450000 & Beetree Creek near Swannanoa & Blue Ridge, rural & 1.000 & 1.044 & 5.291 & 5.46 & 570 & 0.10 \\
\hline 227 & 03455500 & $\begin{array}{l}\text { West Fork Pigeon River above Lake } \\
\text { Logan near Hazelwood }\end{array}$ & Blue Ridge, rural & 1.000 & 1.443 & 2.857 & 27.6 & 241 & 0.17 \\
\hline 236 & 03460000 & Cataloochee Creek near Cataloochee & Blue Ridge, rural & 1.000 & 1.123 & 4.779 & 49.2 & 139 & 0.01 \\
\hline 239 & 03463300 & South Toe River near Celo & Blue Ridge, rural & 1.000 & 1.000 & 4.832 & 43.3 & 106 & 0.18 \\
\hline 246 & 03500240 & Cartoogechaye Creek near Franklin & Blue Ridge, rural & 1.000 & 1.000 & 3.242 & 57.1 & 32.9 & 0.75 \\
\hline \multicolumn{10}{|c|}{ Statistics (based on the above 30 streamgages) } \\
\hline & & Minimum & & 1.000 & 1.000 & 2.857 & 4.12 & 2.53 & 0.01 \\
\hline & & Median & & 1.000 & 1.066 & 4.724 & 27.0 & 24.5 & 0.95 \\
\hline & & Average & & 1.037 & 1.220 & 5.151 & 27.0 & 72.9 & 11.4 \\
\hline & & Maximum & & 1.432 & 2.335 & 18.184 & 63.3 & 570 & 48.8 \\
\hline \multicolumn{10}{|c|}{ National statistics (Granato, 2012) } \\
\hline & & Minimum & & 1.000 & 1.000 & 2.660 & & & \\
\hline & & Median & & 1.020 & 1.850 & 4.360 & & & \\
\hline & & Average & & 1.149 & 1.854 & 4.922 & & & \\
\hline & & Maximum & & 1.770 & 3.520 & 11.310 & & & \\
\hline
\end{tabular}


hydrograph recession ratios and basin characteristics for 41 sites indicated the recession ratios to be random variables, thus precluding the development of multiple linear regression equations between the recession ratios and the data available for the sites (Granato, 2012).

In the current North Carolina study, exploratory "all possible variables" regression analyses were completed to determine if any relations between StreamStats basin characteristics and hydrograph recession ratio statistics were suitable for developing predictive equations. For the minRR values, the analyses suggested that some relations with four or fewer explanatory variables having acceptable adjusted R-square values (greater than or equal to 0.7 ) were possible. However, none of the explanatory variables had a physical basis to account for the variation in the minRR statistic. The results were thus considered a random outcome from the statistical analyses between the numerical values. For the maxRR values, no models had three or fewer explanatory variables and acceptable R-square values (the maximum R-square value was 0.68), but some models had four explanatory variables and $\mathrm{R}$-square values in the range of 0.68 to 0.75 . For the mpvRR values, no models had four or fewer explanatory variables and acceptable R-square values (the maximum R-square value was 0.55$)$. Considering that relations would be needed for all three recession ratio statistics to develop predictive equations, no meaningful and suitable relations (minimum number of explanatory variables coupled with R-square values greater than or equal to 0.7 ) were found between the StreamStats basin characteristics and the three hydrograph recession ratio statistics (minRR, mpvRR, and maxRR).

SELDM allows users to enter and vary the three hydrograph recession ratio statistics under the Hydrograph Recession tab within the Upstream Basin input panel. The national SELDM defaults the minRR, mpvRR, and maxRR statistics to the national study median values of $1.02,1.85$, and 4.36, respectively (Granato, 2012). The North Carolinaenhanced SELDM defaults the three hydrograph recession ratio statistics to the North Carolina study median values of 1.0, 1.07, and 4.72, respectively. Although users can vary all three recession ratio statistics as part of completing exploratory SELDM analyses, the values cannot be less than 1.0. Users may find exploratory analyses meaningful by varying the mpvRR value between the two values of 1.07 and 1.85 for the North Carolina and national models, respectively. Increasing the mpvRR would represent basins in which the runoff peak may be reflective of storage within the watershed or basins with larger drainage areas.

\section{Simulating Stormflow Water Quality}

SELDM stochastically simulates stormflow water quality from the highway site and upstream from the highway-site discharge and then uses mass-balance methods to calculate downstream concentrations and loads from paired highway and upstream values (fig. 1). Both highway-runoff and upstreamstormflow quality can be simulated as a random variable by specifying the average, standard deviation, and skew of concentrations (Granato, 2013). Highway-runoff and upstreamstormflow quality also can be simulated as a dependent random variable by using a regression equation with random variation, which simulates concentrations of one constituent as a function of another. Dependent relations are useful when a constituent for which there is little data has a quantitative relation to another constituent for which there is ample data. Because constituent concentrations commonly vary with flow in receiving waters (O’Connor, 1976; Glysson, 1987; Granato and others, 2009), upstream-stormflow quality also can be simulated by using a water-quality transport curve, which is a dependent relation between flow and concentration. In the North Carolina SELDM enhancement, random water-quality statistics were used to simulate highway-runoff quality, and transport curves based on North Carolina-specific data were used to simulate upstream water-quality. These simulated values were paired with and without BMP treatment to generate the downstream waterquality values for each storm event.

\section{Simulating Highway-Runoff Quality}

In this study, highway-runoff quality was simulated by using the random-concentration option in SELDM. Highway- and urban-runoff concentrations commonly are characterized as approximating a lognormal distribution (Athayde and others, 1983; Di Toro, 1984, Driscoll, Palhegyi, and others, 1989, Driscoll, Shelley, and others, 1989; Driscoll and others, 1990; Van Buren and others, 1997; Novotny, 2004; Granato and Cazenas, 2009; National Research Council, 2009; Granato, 2013). Therefore, SELDM uses the average, standard deviation, and skew of the logarithms of constituent concentrations to simulate highway-runoff concentrations with the frequency-factor method (Granato, 2013). Calculating these statistics is straightforward if all concentrations are above detection limits, but censored values require specific computational procedures for inclusion in the dataset (Helsel and Hirsch, 2002; Croghan and Egeghy, 2003; Antweiler and Taylor, 2008; Granato and Cazenas, 2009).

The FHWA HRDB was developed to serve as a data warehouse for current and future highway-runoff datasets and is used as a preprocessor for SELDM. Data included in the HRDB consist of highway-runoff water-quality and storm-event data from highly impervious highway sites obtained from USGS and non-USGS studies that used established or reasonable protocols for data collection (Granato and Cazenas, 2009). Version 1.0.0a of the HRDB contained event mean concentration (EMC) measurements for over 100 water-quality constituents from over 2,000 storm events within the conterminous United States (Granato and Cazenas, 2009; Smith and Granato, 2010). At the beginning of the current study, the HRDB did not contain much of the available data collected in North Carolina. As part of this current study, highway-runoff data collected by the 
NCDOT and its partners, including data from a 2009-10 USGS bridge deck runoff study (Wagner and others, 2011), were compiled, reviewed, and incorporated into the HRDB to help document available data and to calculate the statistics needed for simulations that are representative of the quality of highway runoff in North Carolina.

The NCDOT identified previous research reports on highway runoff and BMP studies in North Carolina for potential data addition to the HRDB. The reports were provided to an independent contractor who compiled and entered the water-quality and storm-event data into a series of spreadsheets linking the reports, sites, precipitation events, and chemical data, as well as the collection, sampling, and analytic methods documented in the reports (Karthik Narayanaswamy, AECOM, written commun., April 28, 2016). The USGS reviewed the integrity of the sites and data to assess the quality of data and to determine whether they were suitable for addition to the national HRDB. The data were reviewed using five approaches to assess the following:

1. Proximity of the sample collection site to the highway.

2. Correctness of parameter assignation; integrity of sample collection, handling, and analysis; inventory of any missing components such as parameter detection and reporting levels; and appropriateness of sampling container materials, preservative agents, filter pore size, and so forth.

3. Presence or absence of quality-assurance procedures and control samples for field sampling and laboratory analysis. The results of this assessment are documented in the "tblQWHighwayDataSetQAQC" table within the national HRDB.

4. Integrity of the solid phase data. Unfiltered nitrogen, phosphorus, copper, lead, and zinc concentrations were plotted against total suspended solids (TSS) with the expectation that these chemical parameters would be positively correlated to the particle concentration.

5. Integrity of the nutrient data. Mass balances for nitrogen and phosphorus chemical species were checked by comparing summed filtered parameters to total unfiltered parameters.

Where necessary, adjustments were made to bring report data into conformity with standard practices so as to correctly identify and use data below detection/reporting levels. These adjustments included replacing values that were reported below the detection/reporting level with left-censored values at the detection/reporting level. Such replacements are common and prevent the use of values that may be interpreted as false positive values. However, some values in Wagner and others (2011) that were "E-coded" as being below the reporting level but above the detection level were retained in the current study and not left censored at the reporting level. This approach is justified in the case of information-rich chemical analyses (two identification methods, such as chromatographic retention time and characteristic ions as in mass spectrometry). These instances were limited to some trace organic compounds. Additionally, values reported in the initial spreadsheet compilation as zero are almost certainly not zero but rather somewhere below the detection/reporting level. These zero values were also replaced with censored values at the detection/reporting level per standard practice. All data brought into conformity by censoring at the detection/reporting level were included in the North Carolina update to the HRDB and used in subsequent analyses for the current study.

Results of the USGS review of data from NCDOT highway-runoff and BMP studies are shown in tables 5 and 6 and figure 8. A total of 25,087 EMC values and 1,140 storm events for 39 highway runoff sites and 195 analytes from six North Carolina highway-runoff research reports and the USGS/ NCDOT bridge deck runoff study (Wagner and others, 2011) were uploaded to the national HRDB version 1.0.0b (Granato and others, 2018) released near the end of this current study. For 6 of the 39 sites, only storm-event data were uploaded into the national HRDB, meaning EMC values were uploaded into the HRDB for 33 of the 39 highway-runoff sites (table 5). For the 24 highway-runoff sites included in the NCDOT partner studies, the data consisted of 5,034 EMC values and 944 storm events. For the 15 bridge sites included in the USGS/NCDOT bridge deck runoff study, the data consisted of 20,053 EMC values and 196 storm events (Wagner and others, 2011). The EMC data values and storm events from the USGS/NCDOT bridge deck runoff study represent about 80 percent and 17 percent, respectively, of all uploaded values for these two attributes. Data for 17 highway-runoff and BMP site pairs also were retained for BMP performance analyses. Table 6 lists selected site attributes for the highway-runoff and bridge deck runoff sites, as well as the average daily traffic, impervious area for the sampled drainage area, number of traffic lanes, pavement type, and land-use type and class.

Summary statistics (average, standard deviation, skew) were computed for untransformed and log-transformed data on nine constituents and two physicochemical properties for the North Carolina highway-runoff sites (table 7). The nine constituents are TSS, SSC, TN, TP, nitrate plus nitrite $\left(\mathrm{NO}_{3}+\mathrm{NO}_{2}\right)$, and four total recoverable metals (copper, cadmium, lead, and zinc); the two physicochemical properties are turbidity and $\mathrm{pH}$. These site-specific statistics are available under the "NC SELDM summary statistics for physical and chemical data..." link within the USGS data release that accompanies this report (Weaver and others, 2019). Regression on order statistics within the HRDB was used for all datasets with at least one left-censored value (Weibull, 1939; Helsel and Hirsch, 2002; Granato and Cazenas, 2009). No statistics were calculated for datasets with more than 50 percent left-censored values.

For the nine water-quality constituents and two physicochemical properties, the statewide medians of the summary statistics (average, standard deviation, skew) were determined and pre-loaded (as highway random datasets) into the North Carolina-enhanced SELDM. These statewide 
Table 5. Summary of North Carolina Department of Transportation-partner highway-runoff research reports and water-quality data compiled for upload to the national Highway-Runoff Database (HRDB) and for use in best management practice (BMP) performance analyses.

[Only highway-runoff and storm-event data were uploaded to the HRDB after review by the U.S. Geological Survey (USGS). EMC, event mean concentration; NC, North Carolina; UNC, University of North Carolina; HWY, highway; NCSU, North Carolina State University]

\begin{tabular}{|c|c|c|c|c|c|c|c|c|}
\hline $\begin{array}{l}\text { HRDB } \\
\text { highway } \\
\text { dataset } \\
\text { number }{ }^{1}\end{array}$ & $\begin{array}{l}\text { HRDB } \\
\text { highway } \\
\text { dataset } \\
\text { name }^{2}\end{array}$ & Citation & $\begin{array}{c}\text { Sampling } \\
\text { period }\end{array}$ & $\begin{array}{l}\text { Number of } \\
\text { higway- } \\
\text { runoff sites }\end{array}$ & $\begin{array}{l}\text { Number } \\
\text { of BMP } \\
\text { sites }\end{array}$ & Number of EMC values & $\begin{array}{c}\text { Number of storm } \\
\text { events }\end{array}$ & $\begin{array}{l}\text { Number } \\
\text { of unique } \\
\text { analytes }\end{array}$ \\
\hline 15 & $\begin{array}{l}\text { NC } 2001 \text { Highway } \\
\text { Runoff Data UNC }\end{array}$ & $\begin{array}{l}\text { Wu and Allan, } \\
2001\end{array}$ & 1999-2000 & 4 & 0 & 1,658 (HWY) 0 (BMP) & $\begin{array}{c}252 \text { (HWY) } \\
0 \text { (BMP) }\end{array}$ & 18 \\
\hline 16 & $\begin{array}{l}\text { NC } 2006 \text { Highway } \\
\text { Runoff Data } \\
\text { NCSU }\end{array}$ & Line, 2006 & $2003-2005$ & 1 & 1 & 170 (HWY) 168 (BMP) & $\begin{array}{l}14 \text { (HWY) } \\
14 \text { (BMP) }\end{array}$ & 19 \\
\hline 17 & $\begin{array}{l}\text { NC } 2011 \text { Bridge } \\
\text { Deck Data USGS }\end{array}$ & $\begin{array}{l}\text { Wagner and } \\
\text { others, } 2011 \\
\text { (USGS } \\
\text { bridge-deck } \\
\text { runoff study) }\end{array}$ & 2009-2010 & 15 & 0 & $\begin{array}{l}\text { 20,053 (USGS HWY) } \\
\quad 0 \text { (BMP) }\end{array}$ & $\begin{array}{c}196 \text { (USGS HWY) } \\
0 \text { (BMP) }\end{array}$ & 110 \\
\hline 18 & $\begin{array}{l}\text { NC } 2012 \text { Bridge } \\
\text { Deck Data NCSU }\end{array}$ & $\begin{array}{l}\text { Luell and } \\
\text { others, } 2012\end{array}$ & 2009-2011 & 2 & 3 & 449 (HWY) 619 (BMP) & $\begin{array}{c}148 \text { (HWY) } \\
100(\mathrm{BMP})\end{array}$ & 10 \\
\hline 19 & $\begin{array}{l}\text { NC } 2012 \text { Highway } \\
\text { Runoff Data } \\
\text { NCSU }\end{array}$ & $\begin{array}{l}\text { Winston and } \\
\text { others, } 2012\end{array}$ & $2008-2010$ & 4 & 6 & 602 (HWY) 747 (BMP) & $\begin{array}{l}371 \text { (HWY) } \\
107 \text { (BMP) }\end{array}$ & 7 \\
\hline 20 & $\begin{array}{l}\text { NC } 2013 \text { Highway } \\
\text { Runoff Data UNC }\end{array}$ & $\begin{array}{l}\text { Wu and Allan, } \\
2013\end{array}$ & $2011-2012$ & 4 & 4 & $\begin{array}{l}1,482 \text { (HWY) } \\
1,487 \text { (BMP) }\end{array}$ & $\begin{array}{l}77 \text { (HWY) } \\
72 \text { (BMP) }\end{array}$ & 22 \\
\hline 21 & $\begin{array}{l}\text { NC } 2014 \text { Roadway } \\
\text { Runoff Data UNC }\end{array}$ & $\begin{array}{l}\text { Wu and Allan, } \\
2014\end{array}$ & $2007-2009$ & 3 & 3 & 673 (HWY) 642 (BMP) & $\begin{array}{l}82 \text { (HWY) } \\
72 \text { (BMP) }\end{array}$ & 9 \\
\hline \multicolumn{4}{|c|}{ Totals } & 33 & 17 & $\begin{array}{c}\text { 5,034 (HWY) 3,663 } \\
\text { (BMP) 20,053 } \\
\text { (USGS HWY) }\end{array}$ & $\begin{array}{c}944 \text { (HWY) } \\
365 \text { (BMP) } \\
196 \text { (USGS } \\
\text { HWY) }\end{array}$ & 195 \\
\hline
\end{tabular}

${ }^{1}$ The HRDB QW highway dataset number is the “QWHighwayDataSet_ID” field in the HRDB that references the indicated highway-runoff research report.

${ }^{2}$ The HRDB QW highway dataset name is the "tQWHighwayDataSet" field in the HRDB that references the indicated higway-runoff research report 
Table 6. Summary of North Carolina Department of Transportation-partner highway-runoff sampling sites and selected attributes for water-quality data uploaded to the national Highway-Runoff Database (HRDB).

[Shaded cells indicate highway-runoff sites for which only storm-event data were uploaded to the HRDB. NC, North Carolina; I, Interstate; SR, Secondary Road; Blvd, Boulevard; Rd, Road; Cr, Creek; TIA, total impervious area]

\begin{tabular}{|c|c|c|c|c|c|c|c|c|c|c|c|c|}
\hline & & & & & & & & & & & & and use \\
\hline $\begin{array}{c}\text { highway } \\
\text { dataset } \\
\text { number }\end{array}$ & $\begin{array}{c}\text { site } \\
\text { number } \\
\text { (fig. 8) }\end{array}$ & Name & Location & $\begin{array}{l}\text { decimal } \\
\text { degrees }\end{array}$ & $\begin{array}{l}\text { decimal } \\
\text { degrees }\end{array}$ & $\begin{array}{c}\text { traffic, } \\
\text { number of } \\
\text { vehicles }\end{array}$ & $\begin{array}{l}\text { area, } \\
\text { acres }\end{array}$ & $\begin{array}{c}\text { ous } \\
\text { area, } \\
\text { fraction }\end{array}$ & $\begin{array}{c}\text { of } \\
\text { traffic } \\
\text { lanes }\end{array}$ & $\begin{array}{l}\text { Pavement } \\
\text { type }\end{array}$ & Type & Class \\
\hline 15 & 142 & $\begin{array}{l}\text { NC I-40 exit 414, near } \\
\text { Castle Hayne }\end{array}$ & $\begin{array}{l}\text { New Hanover } \\
\text { County }\end{array}$ & 34.349800 & -77.883500 & 20,300 & 0.15 & 1 & 2 & Asphalt & Rural & Forest \\
\hline 15 & 143 & $\begin{array}{l}\text { NC I-40 and SR 1322, near } \\
\text { Willmington }\end{array}$ & $\begin{array}{l}\text { New Hanover } \\
\text { County }\end{array}$ & 34.294000 & -77.862000 & 20,300 & 0.22 & 0.47 & 4 & Asphalt & Rural & $\begin{array}{l}\text { Forest/transpor- } \\
\text { tation }\end{array}$ \\
\hline 15 & 144 & $\begin{array}{l}\text { NC I-40 Bypass near Winston } \\
\text { Salem }\end{array}$ & $\begin{array}{l}\text { Guilford } \\
\text { County }\end{array}$ & 36.093000 & -80.033000 & 52,500 & 2.16 & 0.48 & 4 & Asphalt & Urban & $\begin{array}{l}\text { Forest/ } \\
\quad \text { residential }\end{array}$ \\
\hline 15 & 145 & $\begin{array}{l}\text { NC I-40, Asheville, Buncombe } \\
\text { County Elliptical flow } \\
\text { splitter }\end{array}$ & $\begin{array}{l}\text { Buncombe } \\
\text { County }\end{array}$ & 35.594000 & -82.420000 & 39,000 & 0.16 & 1 & 2 & Asphalt & Urban & Forest/mixed \\
\hline 15 & 146 & $\begin{array}{l}\text { NC I-40, Asheville, Buncombe } \\
\text { County }\end{array}$ & $\begin{array}{l}\text { Buncombe } \\
\text { County }\end{array}$ & 35.594000 & -82.420000 & 39,000 & 0.36 & 0.42 & 4 & Asphalt & Urban & Forest/mixed \\
\hline 15 & 147 & $\begin{array}{l}\text { NC I-40, North of Garner, } \\
\text { Wake County }\end{array}$ & Wake County & 35.717000 & -78.584000 & 78,800 & 3.46 & 0.33 & 6 & Asphalt & Urban & Forest \\
\hline 15 & 148 & $\begin{array}{l}\text { NC 49/W.T. Harris Blvd Over- } \\
\text { pass, Charlotte, Mecklenburg } \\
\text { County TIA } 61 \text { pct }\end{array}$ & $\begin{array}{l}\text { Charlotte, } \\
\text { Mecklenburg } \\
\text { County }\end{array}$ & 35.296000 & -80.743000 & 33,400 & 0.57 & 0.61 & 3 & Asphalt & Urban & $\begin{array}{l}\text { Forest/ } \\
\text { commercial }\end{array}$ \\
\hline 15 & 149 & NC US 601/US 74, Monroe, NC & $\begin{array}{l}\text { Monroe } \\
\text { County }\end{array}$ & 34.958000 & -80.499000 & 9,400 & 13.46 & 0.22 & 5 & Asphalt & Rural & $\begin{array}{l}\text { Forest/ } \\
\text { commercial }\end{array}$ \\
\hline 15 & 150 & $\begin{array}{l}\text { NC US 74, west of SR } \\
1005 \text { at Broad River, } \\
\text { Rutherford County }\end{array}$ & $\begin{array}{l}\text { Rutherford } \\
\text { County }\end{array}$ & 35.307000 & -81.913000 & 9,300 & 0.86 & 0.5 & 4 & Asphalt & Rural & Forest \\
\hline 15 & 151 & $\begin{array}{l}\text { NC W.T. Harris Blvd, Charlotte, } \\
\text { Mecklenburg County }\end{array}$ & $\begin{array}{l}\text { Charlotte, } \\
\text { Mecklenburg } \\
\text { County }\end{array}$ & 35.296000 & -80.743000 & 50,200 & 0.37 & 1 & 3 & Concrete & Urban & $\begin{array}{l}\text { Forest/ } \\
\text { commercial }\end{array}$ \\
\hline 16 & 152 & $\begin{array}{l}\text { NC US } 70 \text { Business swale } \\
\text { influent after grassy strip }\end{array}$ & $\begin{array}{l}\text { New Bern, } \\
\text { Craven } \\
\text { County }\end{array}$ & 35.103600 & -77.036400 & 11,000 & 1.10 & 0.87 & 0 & Asphalt & $\begin{array}{l}\text { Non- } \\
\text { urban }\end{array}$ & $\begin{array}{l}\text { Open space/ } \\
\text { commercial }\end{array}$ \\
\hline 17 & 153 & $\begin{array}{l}\text { NC SR } 1314 \text { Boylston Creek at } \\
\text { Mills River, Bridge } 440008\end{array}$ & $\begin{array}{l}\text { Henderson } \\
\text { County }\end{array}$ & 35.375488 & -82.549095 & 1,400 & 0.24 & 0.98 & 2 & Asphalt & Rural & Agricultural \\
\hline 17 & 154 & $\begin{array}{l}\text { NC I-40 Swannanoa R near } \\
\text { Black Mountain, Bridge } \\
100494\end{array}$ & $\begin{array}{l}\text { Buncombe } \\
\text { County }\end{array}$ & 35.618862 & -82.308136 & 25,500 & 1.41 & 1 & 4 & Concrete & $\begin{array}{l}\text { Non- } \\
\text { urban }\end{array}$ & $\begin{array}{l}\text { Residential/open } \\
\text { space }\end{array}$ \\
\hline
\end{tabular}


Table 6. Summary of North Carolina Department of Transportation-partner highway-runoff sampling sites and selected attributes for water-quality data uploaded to the national Highway-Runoff Database (HRDB).-Continued

[Shaded cells indicate highway-runoff sites for which only storm-event data were uploaded to the HRDB. NC, North Carolina; I, Interstate; SR, Secondary Road; Blvd, Boulevard; Rd, Road; Cr, Creek; TIA, total impervious area]

\begin{tabular}{|c|c|c|c|c|c|c|c|c|c|c|c|c|}
\hline HRDB & HRDB & & & & & & & Imnervi- & Number & & & and use \\
\hline $\begin{array}{l}\text { highway } \\
\text { dataset } \\
\text { number }\end{array}$ & $\begin{array}{l}\text { site } \\
\text { number } \\
\text { (fig. 8) }\end{array}$ & Name & Location & $\begin{array}{l}\text { decimal } \\
\text { degrees }\end{array}$ & $\begin{array}{l}\text { decimal } \\
\text { degrees }\end{array}$ & $\begin{array}{l}\text { traffic, } \\
\text { number of } \\
\text { vehicles }\end{array}$ & $\begin{array}{l}\text { area, } \\
\text { acres }\end{array}$ & $\begin{array}{c}\text { ous } \\
\text { area, } \\
\text { fraction }\end{array}$ & $\begin{array}{c}\text { of } \\
\text { traffic } \\
\text { lanes }\end{array}$ & $\begin{array}{l}\text { Pavement } \\
\text { type }\end{array}$ & Type & Class \\
\hline 17 & 155 & $\begin{array}{l}\text { NC SR } 1742 \text { Flat Creek near } \\
\text { Weaverville, Bridge } 100250\end{array}$ & Buncombe County & 35.718601 & -82.623940 & 400 & 0.05 & 0.98 & 2 & Asphalt & Rural & Forest \\
\hline 17 & 156 & $\begin{array}{l}\text { NC SR } 2207 \text { Big Ivy Creek near } \\
\text { Mars Hill, Bridge } 100734\end{array}$ & Buncombe County & 35.791286 & -82.538826 & 1,500 & 0.08 & 1 & 2 & Concrete & Rural & Forest/mixed \\
\hline 17 & 157 & $\begin{array}{l}\text { NC SR } 2173 \text { Dillingham Creek at } \\
\text { Barnardsville, Bridge } 100145\end{array}$ & Buncombe County & 35.768642 & -82.435966 & 1,800 & 0.32 & 1 & 2 & Concrete & Rural & $\begin{array}{l}\text { Forest/ } \\
\quad \text { agricultural }\end{array}$ \\
\hline 17 & 158 & $\begin{array}{r}\text { NC I-85 Mallard Creek near } \\
\text { Charlotte, Bridge } 590296\end{array}$ & $\begin{array}{l}\text { Mecklenburg } \\
\text { County }\end{array}$ & 35.319749 & -80.751900 & 112,000 & 0.39 & 1 & 10 & Concrete & Urban & Forest/mixed \\
\hline 17 & 159 & $\begin{array}{l}\text { NC SR } 1461 \text { Little River at } \\
\text { Orange Factory, Bridge } 310064\end{array}$ & $\begin{array}{l}\text { Durham } \\
\text { County }\end{array}$ & 36.141617 & -78.919357 & 500 & 0.13 & 0.99 & 2 & Concrete & Rural & Forest \\
\hline 17 & 160 & $\begin{array}{l}\text { NC SR } 1616 \text { Mountain Creek near } \\
\text { Bahama, Bridge } 310005\end{array}$ & $\begin{array}{l}\text { Durham } \\
\text { County }\end{array}$ & 36.152363 & -78.902306 & 2,800 & 0.21 & 1 & 2 & Asphalt & Rural & $\begin{array}{l}\text { Forest/ } \\
\quad \text { agricultural }\end{array}$ \\
\hline 17 & 161 & $\begin{array}{l}\text { NC SR } 2006 \text { Perry Creek near } \\
\text { Raleigh, Bridge } 910124\end{array}$ & Wake County & 35.879940 & -78.547569 & 13,000 & 0.30 & 1 & 4 & Concrete & $\begin{array}{l}\text { Non- } \\
\text { urban }\end{array}$ & Forest/mixed \\
\hline 17 & 162 & $\begin{array}{l}\text { NC I-540 Mango Creek near } \\
\text { Raleigh, Bridge } 911102\end{array}$ & Wake County & 35.784016 & -78.513542 & 34,000 & 1.29 & 1 & 6 & Concrete & Urban & $\begin{array}{l}\text { Forest/ } \\
\quad \text { residential }\end{array}$ \\
\hline 17 & 163 & $\begin{array}{l}\text { NC SR } 1006 \text { Swift Creek at } \\
\text { Garner, Bridge } 910255\end{array}$ & Wake County & 35.704975 & -78.656303 & 11,500 & 0.18 & 0.98 & 2 & Concrete & Rural & $\begin{array}{l}\text { Forest/ } \\
\quad \text { residential }\end{array}$ \\
\hline 17 & 164 & $\begin{array}{l}\text { NC SR } 1006 \text { Middle Creek near } \\
\text { Fuquay-Varina, Bridge } 910273\end{array}$ & Wake County & 35.609348 & -78.686295 & 5,000 & 0.15 & 1 & 2 & Asphalt & Rural & $\begin{array}{l}\text { Forest/ } \\
\quad \text { residential }\end{array}$ \\
\hline 17 & 165 & $\begin{array}{l}\text { NC SR } 411 \text { Black River near } \\
\text { Tomahawk, Bridge } 810014\end{array}$ & $\begin{array}{l}\text { Sampson } \\
\text { County }\end{array}$ & 34.754852 & -78.288788 & 750 & 0.11 & 1 & 2 & Asphalt & Rural & $\begin{array}{l}\text { Forest/ } \\
\quad \text { agricultural }\end{array}$ \\
\hline 17 & 166 & $\begin{array}{l}\text { NC SR } 133 \text { Town Creek near } \\
\text { Wilmington, Bridge } 90061\end{array}$ & $\begin{array}{c}\text { Brunswick } \\
\text { County }\end{array}$ & 34.136600 & -77.987350 & 5,600 & 0.18 & 1 & 2 & Asphalt & Rural & $\begin{array}{l}\text { Forest/ } \\
\text { commercial }\end{array}$ \\
\hline 17 & 167 & $\begin{array}{l}\text { NC US } 74 \text { Smith Cr near } \\
\text { Wilmington near SR 1302, } \\
\text { Bridge } 640131\end{array}$ & $\begin{array}{l}\text { New Hanover } \\
\text { County }\end{array}$ & 34.258230 & -77.918964 & 26,000 & 0.49 & 1 & 4 & Concrete & $\begin{array}{l}\text { Non- } \\
\text { urban }\end{array}$ & Commercial \\
\hline 18 & 168 & $\begin{array}{l}\text { NC I-540 Mango Creek bioreten- } \\
\text { tion inlet }\end{array}$ & Wake County & 35.784278 & -78.513444 & 34,000 & 0.98 & 1 & 6 & Concrete & Urban & $\begin{array}{l}\text { Open space/resi- } \\
\text { dential }\end{array}$ \\
\hline 18 & 169 & NC I-540 Mango Creek swale inlet & Wake County & 35.784278 & -78.513444 & 34,000 & 1.13 & 1 & 6 & Concrete & Urban & $\begin{array}{l}\text { Open space/resi- } \\
\text { dential }\end{array}$ \\
\hline
\end{tabular}


Table 6. Summary of North Carolina Department of Transportation-partner highway-runoff sampling sites and selected attributes for water-quality data uploaded to the national Highway-Runoff Database (HRDB).-Continued

[Shaded cells indicate highway-runoff sites for which only storm-event data were uploaded to the HRDB. NC, North Carolina; I, Interstate; SR, Secondary Road; Blvd, Boulevard; Rd, Road; Cr, Creek; TIA, total impervious area]

\begin{tabular}{|c|c|c|c|c|c|c|c|c|c|c|c|c|}
\hline & & & & & & & & & & & & Land use \\
\hline $\begin{array}{l}\text { highway } \\
\text { dataset } \\
\text { number }\end{array}$ & $\begin{array}{l}\text { site } \\
\text { number } \\
\text { (fig. 8) }\end{array}$ & Name & Location & $\begin{array}{l}\text { decimal } \\
\text { degrees }\end{array}$ & $\begin{array}{l}\text { decimal } \\
\text { degrees }\end{array}$ & $\begin{array}{l}\text { traffic, } \\
\text { number of } \\
\text { vehicles }\end{array}$ & $\begin{array}{c}\text { age } \\
\text { area, } \\
\text { acres }\end{array}$ & $\begin{array}{c}\text { ous } \\
\text { area, } \\
\text { fraction }\end{array}$ & $\begin{array}{l}\text { of } \\
\text { traffic } \\
\text { lanes }\end{array}$ & $\begin{array}{l}\text { Pavement } \\
\text { type }\end{array}$ & Type & Class \\
\hline 19 & 170 & $\begin{array}{l}\text { NC I-40 permeable friction course } \\
\text { near Strickland Crossroads Rd } \\
\text { swale influent }\end{array}$ & Johnston County & 35.368000 & -78.495000 & 20,000 & 0.01 & 1 & 4 & Other & Rural & Agricultural \\
\hline 19 & 171 & $\begin{array}{l}\text { NC I-40 permeable friction course } \\
\text { near Five Points Rd } \\
\text { swale influent }\end{array}$ & Johnston County & 35.350400 & -78.479200 & 18,000 & 0.02 & 1 & 4 & Other & Rural & Agricultural \\
\hline 19 & 172 & $\begin{array}{l}\text { NC I-40 permeable friction course } \\
\text { near Giddensville Rd } \\
\text { swale influent }\end{array}$ & Sampson County & 35.148000 & -78.218800 & 18,000 & 0.02 & 1 & 4 & Other & Rural & Forest/agricultural \\
\hline 19 & 173 & $\begin{array}{l}\text { NC I-40 permeable friction course } \\
\text { near McGowen Rd } \\
\text { swale influent }\end{array}$ & Duplin County & 35.050000 & -78.154800 & 22,000 & 0.01 & 1 & 4 & Other & Rural & Forest/agricultural \\
\hline 20 & 174 & $\begin{array}{l}\text { NC I-77 permeable friction course } \\
\text { edge of pavement near } \\
\text { Charlotte }\end{array}$ & $\begin{array}{l}\text { Charlotte, } \\
\text { Mecklenburg } \\
\text { County }\end{array}$ & 35.143900 & -80.900600 & 75,000 & 0.06 & 1 & 4 & Other & $\begin{array}{l}\text { Non- } \\
\text { urban }\end{array}$ & Commercial \\
\hline 20 & 175 & $\begin{array}{l}\text { NC I-77 control site standard } \\
\text { asphalt road edge of pavement } \\
\text { near Charlotte }\end{array}$ & $\begin{array}{l}\text { Charlotte, } \\
\text { Mecklenburg } \\
\text { County }\end{array}$ & 35.247900 & -80.845600 & 88,500 & 0.06 & 1 & 4 & Asphalt & $\begin{array}{l}\text { Non- } \\
\text { urban }\end{array}$ & Residential \\
\hline 20 & 176 & $\begin{array}{l}\text { NC I-85 NovaChip road edge of } \\
\text { pavement near Lexington }\end{array}$ & $\begin{array}{l}\text { Davidson, } \\
\text { Mecklenburg } \\
\text { County }\end{array}$ & 35.790000 & -80.225000 & 25,000 & 0.04 & 1 & 4 & Other & Rural & Forest \\
\hline 20 & 177 & $\begin{array}{l}\text { NC I- } 85 \text { control site standard } \\
\text { asphalt } \\
\text { road edge of pavement near } \\
\text { Lexington }\end{array}$ & $\begin{array}{l}\text { Davidson, } \\
\text { Mecklenburg } \\
\text { County }\end{array}$ & 35.802700 & -80.193900 & 25,000 & 0.05 & 1 & 4 & Asphalt & Rural & Forest \\
\hline 21 & 178 & $\begin{array}{l}\text { NC SR } 1717 \text { Jordan Lake North } \\
\text { swale influent }\end{array}$ & $\begin{array}{l}\text { Chapell Hill, } \\
\text { Orange County }\end{array}$ & 35.815900 & -79.056000 & 2,600 & 0.03 & 1 & 2 & Asphalt & Rural & Forest/residential \\
\hline 21 & 179 & $\begin{array}{l}\text { NC SR } 1943 \text { Jordan Lake South } \\
\text { swale influent }\end{array}$ & $\begin{array}{l}\text { Pittsboro, Chatham } \\
\text { County }\end{array}$ & 35.705833 & -79.102500 & 590 & 0.02 & 1 & 2 & Asphalt & Rural & Forest/residential \\
\hline 21 & 180 & $\begin{array}{l}\text { NC SR } 1360 \text { Mountain Island } \\
\text { Lake } \\
\text { swale influent }\end{array}$ & $\begin{array}{l}\text { Ironton, Lincoln } \\
\text { County }\end{array}$ & 35.442900 & -81.107200 & 1,400 & 0.03 & 1 & 2 & Asphalt & Rural & Forest/residential \\
\hline
\end{tabular}




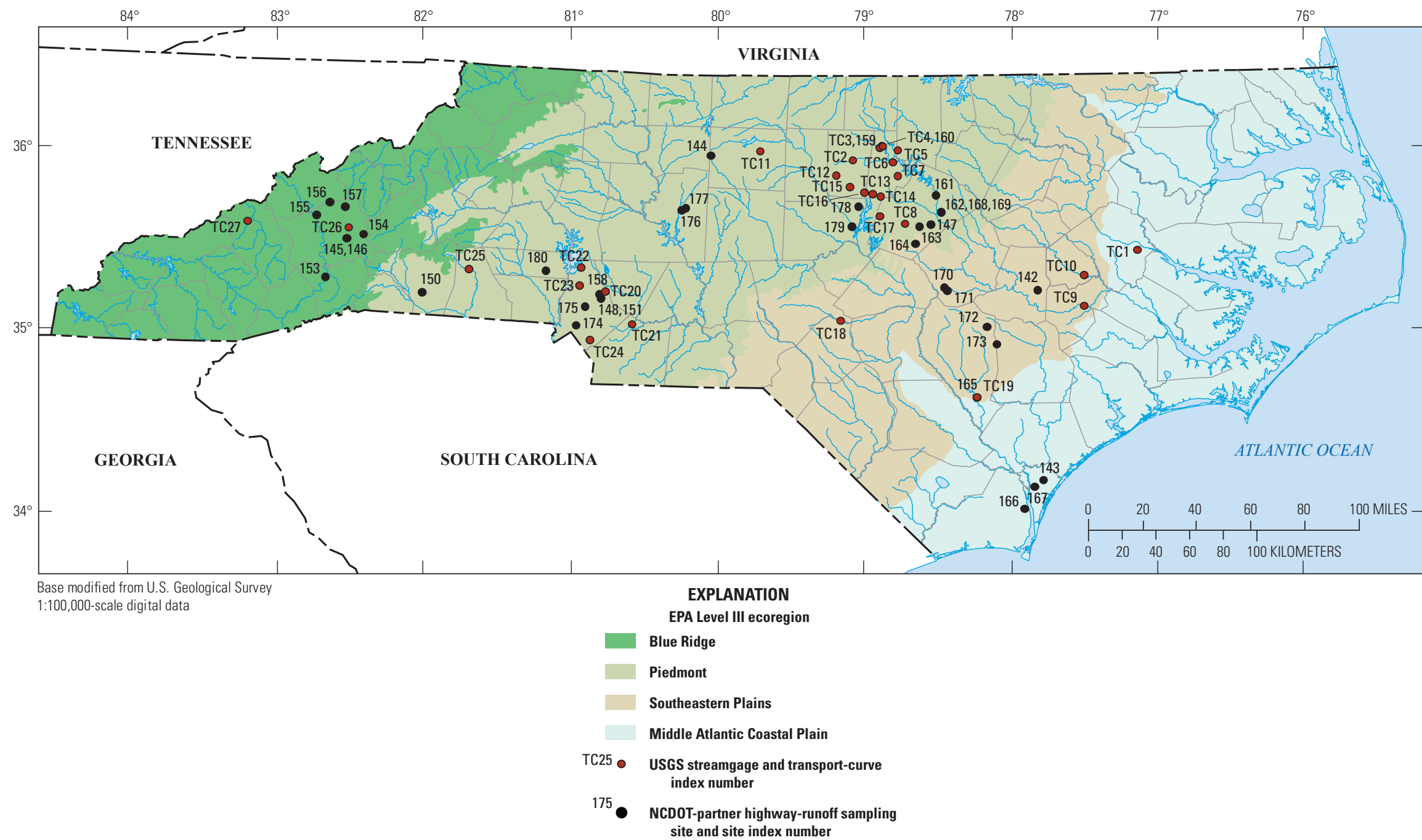

Figure 8. Map showing 39 North Carolina Department of Transportation (NCDOT)-partner highway-runoff sampling sites across North Carolina for which water-quality and (or) storm-event data were added to the national Highway-Runoff Database (Granato and Cazenas, 2009) and 27 selected U.S. Geological Survey (USGS) continuous-record streamgages for which water-quality transport curves were developed. EPA, U.S. Environmental Protection Agency. 
Table 7. Statewide medians of statistics for selected water-quality constituents at North Carolina highway-runoff sites.

[Statistics in shaded cells were pre-loaded into the North Carolina Stochastic Empirical Loading and Dilution Model (SELDM) and are suitable for levelone planning analyses (see text for further discussion). Statistics for $\mathrm{pH}$ were pre-loaded in the North Carolina SELDM as untransformed (arithmetic) values because the scale of possible $\mathrm{pH}$ values (0 to 14) precludes log transformation. HRDB, Highway Runoff Database; EPA, U.S. Environmental Protection Agency; pcode, parameter code; EMC, event mean concentration; mg/L, milligram per liter; ntu, nephelometric turbidity unit; n/a, not applicable]

\begin{tabular}{|c|c|c|c|c|c|c|c|c|c|c|}
\hline \multirow{3}{*}{$\begin{array}{c}\text { HRDB } \\
\text { parameter } \\
\text { identification }\end{array}$} & \multirow{3}{*}{$\begin{array}{c}\text { EPA } \\
\text { pcode }\end{array}$} & \multirow{3}{*}{$\begin{array}{c}\text { Parameter name and } \\
\text { units }\end{array}$} & \multirow{3}{*}{$\begin{array}{l}\text { Number } \\
\text { of sites }\end{array}$} & \multirow{3}{*}{$\begin{array}{c}\text { Number } \\
\text { of } \\
\text { EMC } \\
\text { values }\end{array}$} & \multicolumn{6}{|c|}{ Statewide medians for indicated EMC summary statistics } \\
\hline & & & & & \multicolumn{3}{|c|}{ Arithmetic } & \multicolumn{3}{|c|}{ Log10 transformed } \\
\hline & & & & & Average & $\begin{array}{l}\text { Standard } \\
\text { deviation }\end{array}$ & Skew & Average & $\begin{array}{l}\text { Standard } \\
\text { deviation }\end{array}$ & Skew \\
\hline 138 & p00530 & $\begin{array}{l}\text { Solids, suspended, water, } \\
\text { milligrams per liter } \\
(\mathrm{mg} / \mathrm{L})\end{array}$ & 33 & 596 & 48.5 & 54 & 1.72 & 1.44 & 0.374 & 0.111 \\
\hline 156 & p00600 & $\begin{array}{l}\text { Total nitrogen, water, } \\
\text { unfiltered, milligrams } \\
\text { per liter }(\mathrm{mg} / \mathrm{L})\end{array}$ & 29 & 503 & 1.05 & 0.555 & 0.905 & -0.042 & 0.229 & -0.045 \\
\hline 188 & p00665 & $\begin{array}{l}\text { Phosphorus, water, } \\
\text { unfiltered, milligrams } \\
\text { per liter }(\mathrm{mg} / \mathrm{L})\end{array}$ & 33 & 597 & 0.17 & 0.144 & 2.04 & -0.891 & 0.307 & 0.383 \\
\hline $98 / 100$ & $\begin{array}{l}\mathrm{p} 00400 / \\
\mathrm{p} 00403\end{array}$ & $\begin{array}{l}\mathrm{pH} \text {, water, unfiltered, } \\
\text { field, standard units }\end{array}$ & 24 & 372 & 6.89 & 0.409 & -0.236 & $\mathrm{n} / \mathrm{a}$ & $\mathrm{n} / \mathrm{a}$ & $\mathrm{n} / \mathrm{a}$ \\
\hline $290 / 366$ & $\begin{array}{r}\mathrm{p} 01027 / \\
\mathrm{p} 01113\end{array}$ & $\begin{array}{l}\text { Cadmium, water, unfil- } \\
\text { tered, recoverable, } \\
\text { micrograms per liter } \\
(\mu \mathrm{g} / \mathrm{L})\end{array}$ & 20 & 284 & 0.136 & 0.151 & 1.78 & -1.01 & 0.295 & 0.439 \\
\hline 304 & p01042 & $\begin{array}{l}\text { Copper, water, unfiltered, } \\
\text { recoverable, micro- } \\
\text { grams per liter }(\mu \mathrm{g} / \mathrm{L})\end{array}$ & 18 & 217 & 21.9 & 22.1 & 2.35 & 1.09 & 0.313 & 0.581 \\
\hline 313 & p01051 & $\begin{array}{l}\text { Lead, water, unfiltered, } \\
\text { recoverable, micro- } \\
\text { grams per liter }(\mu \mathrm{g} / \mathrm{L})\end{array}$ & 20 & 284 & 7.69 & 6.98 & 1.86 & 0.745 & 0.409 & 0.184 \\
\hline
\end{tabular}


medians (arithmetic and $\log 10$ ), the number of North Carolina highway-runoff sites for each constituent, and the number of EMC values are listed in table 7. The statewide medians are suitable for level-one analyses that can be completed using the North Carolina-enhanced SELDM. The site-specific summary statistics provided in the companion data release (Weaver and others, 2019) can be selected by users to perform more in-depth level-two analyses where such site-specific or regional data are more appropriate.

\section{Simulating Upstream Water Quality}

Upstream water quality was simulated in the North Carolina-enhanced SELDM by using the water-quality transport-curve option. Water-quality transport curves commonly are used to estimate in-stream concentrations as a function of streamflow (Biesecker and Leifeste, 1975; O'Connor, 1976; Glysson, 1987; Vogel and others, 2005; Granato, 2006; Landers and others, 2007; Granato and others, 2009). The transport-curve option was developed for use in SELDM because concentrations of many constituents commonly vary because of washoff and dilution processes in receiving waters. For constituents that are predominantly derived from land-surface runoff and transport of streambed materials, increasing flow may increase concentrations (washoff). For example, concentrations of sediment and sediment-associated constituents (selected nutrients, organic compounds, and trace elements) commonly increase with increasing streamflow above a base-flow threshold because these constituents are mobilized from the stream or land surface during storms. For some constituents that are predominantly derived from geologic or point sources such as WWTPs, increasing flow may dilute concentrations (dilution) (Granato and others, 2009). If a water-quality constituent has both point and nonpoint sources, for example TP, then concentrations may decrease with increasing flow while dilution is the dominant process, and then increase as runoff and transport become the dominant processes.

For the North Carolina-enhanced SELDM, water-quality transport curves were developed for six constituents (SSC, TN, TP, copper, lead, zinc) and one physicochemical property (turbidity) by using data retrieved from the USGS NWIS database (https://waterdata.usgs.gov/nwis) for 27 streamgages across North Carolina (fig. 8). The USGS data were selected because they were collected with documented and proven protocols (see for example Wagner and others, 2011) and because each water-quality sample consisted of a measured concentration and a corresponding measured instantaneous flow value. A sufficient number of paired water-quality and streamflow measurements (at least 20) were available to develop 18 one-segment and 39 two-segment transport curves (table 8). These transport curves were developed using the Kendall-Theil Robust Line (KTRLine) regression techniques documented by Granato (2006). Each segment of a transport curve has five components: the (1) intercept and (2) slope provide (3) the equation of the line segment; (4) the median absolute deviation (MAD) provides the random scatter of points above and below the line; and (5) the MaxX defines the maximum measured flow for both one- and two-segment transport curves and also indicates the transition point for the first segment of a two-segment transport curve. The equation parameters for the transport curves (either one or two line segments; table 8) have been pre-loaded into the North Carolina-enhanced SELDM under the Upstream Transport Curve tab within the WaterQuality Menu input module.

Among the 27 streamgages for which transport curves were developed, 20 are within the Piedmont ecoregion, 2 are within the Blue Ridge ecoregion, 4 are within the Southeastern Plains ecoregion, and 1 is within the Middle Atlantic Coastal Plain ecoregion (fig. 8). Drainage areas of the 27 streamgages range from $0.266 \mathrm{mi}^{2}$ (site TC24) to $2,692 \mathrm{mi}^{2}$ (site TC9), and 23 of these streamgages have drainage areas of less than $80 \mathrm{mi}^{2}$. Selection of streamgages for analyses and development of the curves reflected attempts to provide curves in each ecoregion, with emphasis on streamgages considered rural or urban, those located downstream from a WTTP, or streamgages having a substantial presence of forested or agricultural land cover in the basin. Selected land cover percentages based on the 2011 National Land Cover Database were compiled for each streamgage by using the USGS StreamStats application (https://streamstats.usgs.gov/ss/).

Development and use of a water-quality transport curve is a three-step process. First, data are collected and streamflows are converted to units of cubic foot per second per square mile $\left(\left[\mathrm{ft}^{3} / \mathrm{s}\right] / \mathrm{mi}^{2}\right)$ so that a curve developed with data from one site may be applied to estimate concentrations at a hydrologically similar site. Second, a curve relating streamflow to a waterquality constituent or physicochemical property is developed with the data by fitting a one- or two-segment regression model in logarithmic space. The intercept and slope of each segment define the line. If there are two (or more) segments, the intersection of the adjoining segments determines the transition point, which is designated as the MaxX of the first segment. The largest MaxX for a given transport curve indicates the maximum flow value in the dataset used to calculate the regression equation. Any simulated flows above this value represent extrapolation of the transport curve. For the current study, MaxX values in arithmetic space (table 8) ranged from about 4 to $1,293\left(\mathrm{ft}^{3} / \mathrm{s}\right) / \mathrm{mi}^{2}$ with a median and average of about 52 and $107\left(\mathrm{ft}^{3} / \mathrm{s}\right) / \mathrm{mi}^{2}$, respectively. In comparison, Weaver and others (2009) developed equations indicating the flood with an annual exceedance risk of 1 percent (commonly known as the 100-year flood) was on the order of $300\left(\mathrm{ft}^{3} / \mathrm{s}\right) / \mathrm{mi}^{2}$ in and around North Carolina. The MAD value is a measure of the random variation of measurements above and below the regression line. SELDM uses the regression line to calculate the most probable value of concentration for a given stormflow and uses the MAD to generate individual concentrations above and below this regression-line value. Figure $9 A$ shows an example two-segment transport curve for SSC at the USGS streamgage on Mountain Creek at Secondary Road 1617 near Bahama (site TC4; table 8, fig. 8) in Durham County, 


\section{Assessing Water Quality From Highway Runoff at Selected Sites in North Carolina with SELDM}

Table 8. Water-quality transport-curve statistics for selected constituents at 27 U.S. Geological Survey (USGS) streamgages in North Carolina.

[All transport curves were developed by using the common logarithms of stormflow (in cubic feet per second per square mile) as the explanatory variable and concentration (in the noted units) as the dependent variable. Equation parameters are presented in logarithmic (base 10) form. Rural basins are defined as having impervious area less than 10 percent. Urban basins are defined as having impervious area great than or equal to 10 percent. Mixed basins have less than 10 percent impervious area, but developed area is 20 percent or more of the basin, possibly reflecting transition from rural to urban. Shaded cells indicate transport curves that were selected to represent low, medium, or high ranges of concentration levels for the purposes of the water-quality simulations presented in this report. NLCD, National Land Cover Database; EPA, U.S. Environmental Protection Agency; mi² $^{2}$ square mile; MAD, median absolute deviation; MaxX, maximum measured flow for both one- and two-segment transport curves; n/a, not applicable; WWTP, wastewater treatment plant]

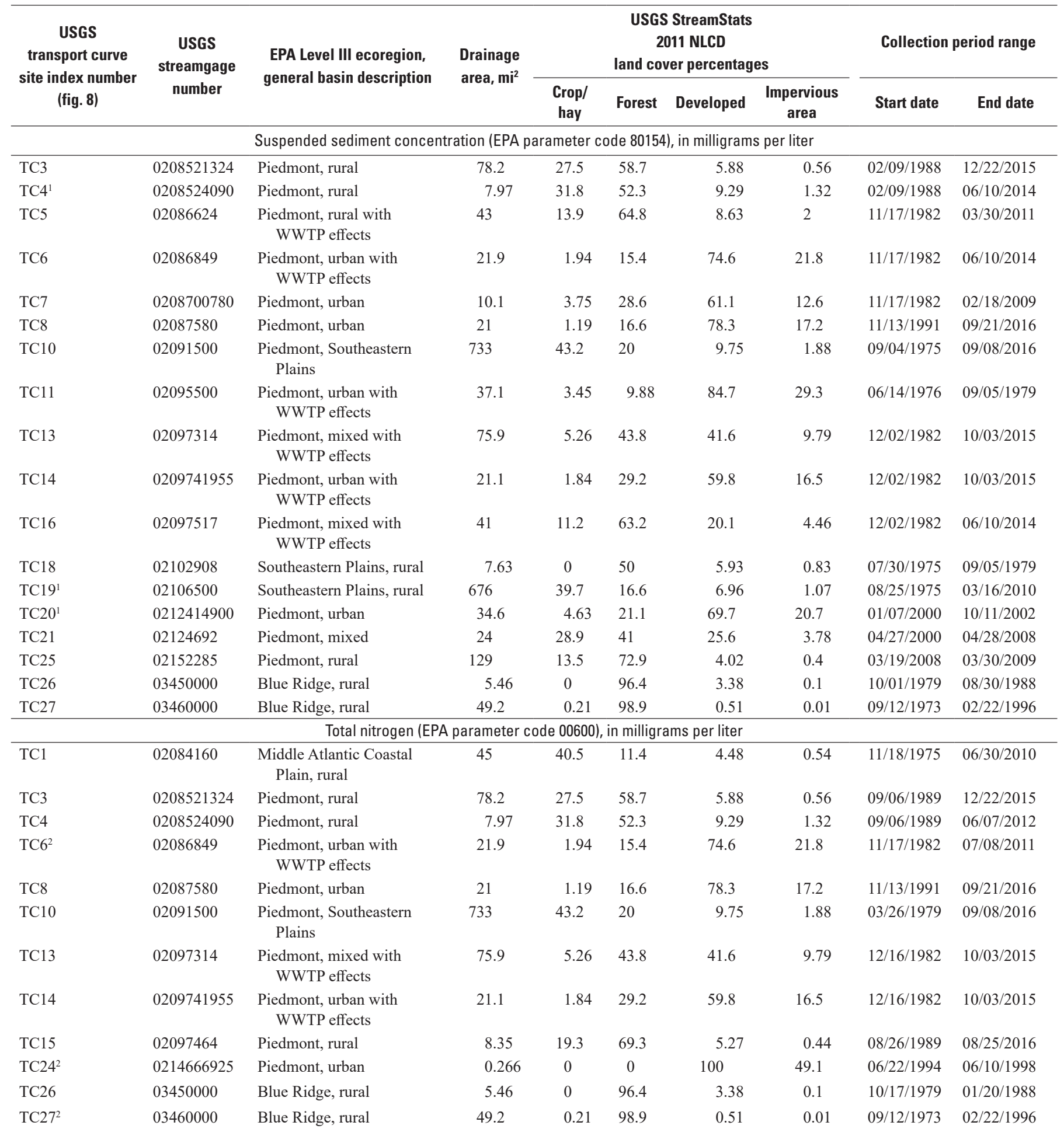


Table 8. Water-quality transport-curve statistics for selected constituents at 27 U.S. Geological Survey (USGS) streamgages in North Carolina.-Continued

[All transport curves were developed by using the common logarithms of stormflow (in cubic feet per second per square mile) as the explanatory variable and concentration (in the noted units) as the dependent variable. Equation parameters are presented in logarithmic (base 10) form. Rural basins are defined as having impervious area less than 10 percent. Urban basins are defined as having impervious area great than or equal to 10 percent. Mixed basins have less than 10 percent impervious area, but developed area is 20 percent or more of the basin, possibly reflecting transition from rural to urban. Shaded cells indicate transport curves that were selected to represent low, medium, or high ranges of concentration levels for the purposes of the water-quality simulations presented in this report. NLCD, National Land Cover Database; EPA, U.S. Environmental Protection Agency; $\mathrm{mi}^{2}$, square mile; MAD, median absolute deviation; MaxX, maximum measured flow for both one- and two-segment transport curves; n/a, not applicable; WWTP, wastewater treatment plant]

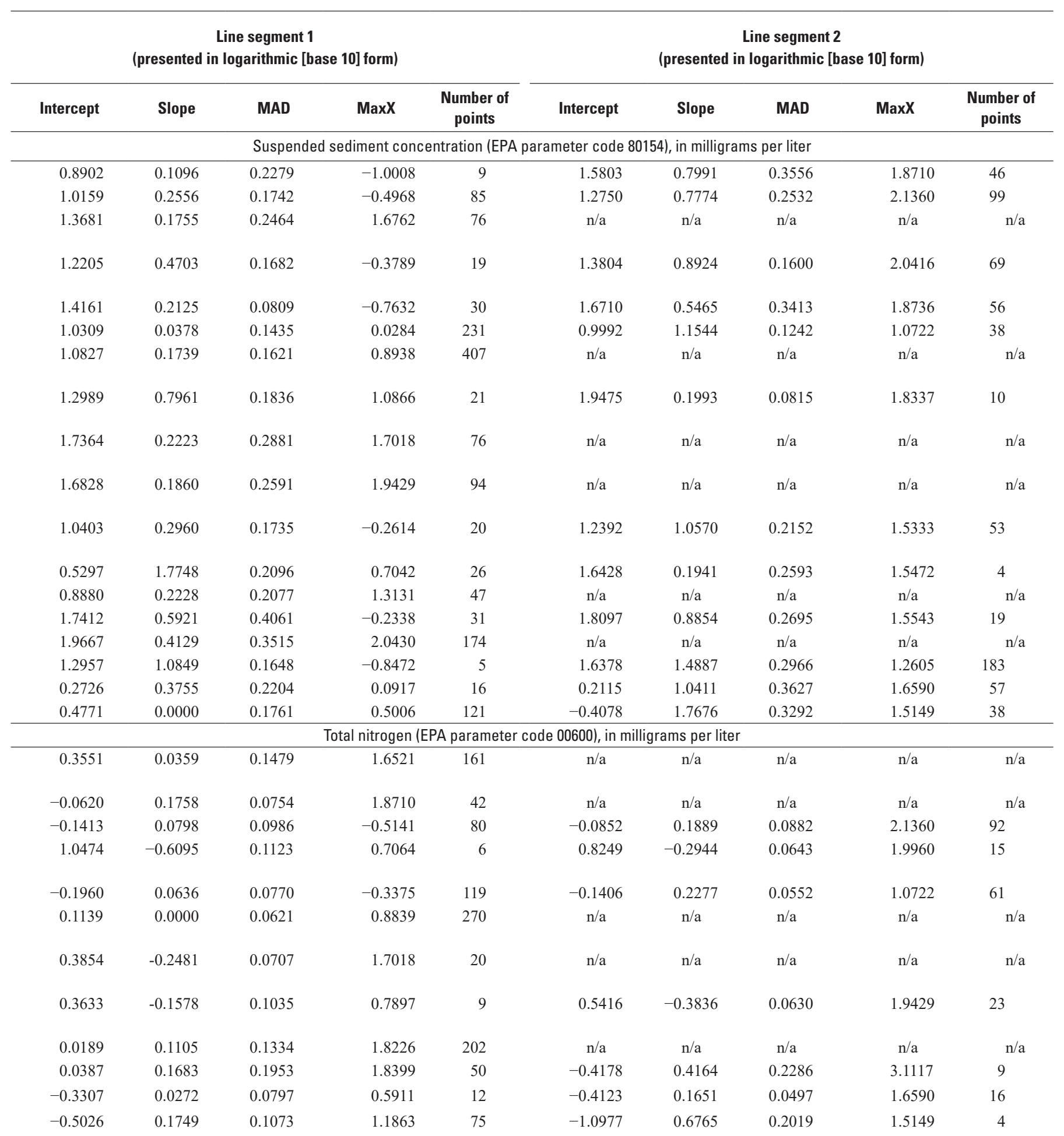




\section{Assessing Water Quality From Highway Runoff at Selected Sites in North Carolina with SELDM}

Table 8. Water-quality transport-curve statistics for selected constituents at 27 U.S. Geological Survey (USGS) streamgages in North Carolina.-Continued

[All transport curves were developed by using the common logarithms of stormflow (in cubic feet per second per square mile) as the explanatory variable and concentration (in the noted units) as the dependent variable. Equation parameters are presented in logarithmic (base 10) form. Rural basins are defined as having impervious area less than 10 percent. Urban basins are defined as having impervious area great than or equal to 10 percent. Mixed basins have less than 10 percent impervious area, but developed area is 20 percent or more of the basin, possibly reflecting transition from rural to urban. Shaded cells indicate transport curves that were selected to represent low, medium, or high ranges of concentration levels for the purposes of the water-quality simulations presented in this report. NLCD, National Land Cover Database; EPA, U.S. Environmental Protection Agency; mi² $^{2}$ square mile; MAD, median absolute deviation; MaxX, maximum measured flow for both one- and two-segment transport curves; n/a, not applicable; WWTP, wastewater treatment plant]

\begin{tabular}{|c|c|c|c|c|c|c|c|c|c|}
\hline \multirow{2}{*}{$\begin{array}{c}\text { USGS } \\
\text { transport curve } \\
\text { site index number } \\
\text { (fig. 8) }\end{array}$} & \multirow{2}{*}{$\begin{array}{l}\text { USGS } \\
\text { streamgage } \\
\text { number }\end{array}$} & \multirow{2}{*}{$\begin{array}{l}\text { EPA Level III ecoregion, } \\
\text { general basin description }\end{array}$} & \multirow{2}{*}{$\begin{array}{l}\text { Drainage } \\
\text { area, } \mathrm{mi}^{2}\end{array}$} & \multicolumn{4}{|c|}{$\begin{array}{c}\text { USGS StreamStats } \\
2011 \text { NLCD } \\
\text { land cover percentages }\end{array}$} & \multicolumn{2}{|c|}{ Collection period range } \\
\hline & & & & $\begin{array}{l}\text { Crop/ } \\
\text { hay }\end{array}$ & Forest & Developed & $\begin{array}{l}\text { Impervious } \\
\text { area }\end{array}$ & Start date & End date \\
\hline \multicolumn{10}{|c|}{ Total phosphorus (EPA parameter code 00665), in milligrams per liter } \\
\hline TC1 & 02084160 & $\begin{array}{l}\text { Middle Atlantic Coastal } \\
\text { Plain, rural }\end{array}$ & 45 & 40.5 & 11.4 & 4.48 & 0.54 & $05 / 08 / 1992$ & $02 / 19 / 1997$ \\
\hline TC6 & 02086849 & $\begin{array}{l}\text { Piedmont, urban with } \\
\text { WWTP effects }\end{array}$ & 21.9 & 1.94 & 15.4 & 74.6 & 21.8 & $04 / 21 / 1992$ & $06 / 10 / 2014$ \\
\hline TC8 & 02087580 & Piedmont, urban & 21 & 1.19 & 16.6 & 78.3 & 17.2 & $11 / 13 / 1991$ & $09 / 05 / 2003$ \\
\hline TC10 & 02091500 & $\begin{array}{l}\text { Piedmont, Southeastern } \\
\text { Plains }\end{array}$ & 733 & 43.2 & 20 & 9.75 & 1.88 & 02/07/1999 & $09 / 02 / 2003$ \\
\hline TC8 & 02087580 & Piedmont, urban & 21 & 1.19 & 16.6 & 78.3 & 17.2 & $10 / 09 / 2012$ & $09 / 21 / 2016$ \\
\hline TC9 & 02089500 & $\begin{array}{l}\text { Piedmont, Southeastern } \\
\text { Plains }\end{array}$ & 2692 & 26.1 & 32.6 & 19.4 & 4.35 & $10 / 24 / 2012$ & $08 / 11 / 2016$ \\
\hline TC10 & 02091500 & $\begin{array}{l}\text { Piedmont, Southeastern } \\
\text { Plains }\end{array}$ & 733 & 43.2 & 20 & 9.75 & 1.88 & $10 / 04 / 2012$ & 09/08/2016 \\
\hline $\mathrm{TC} 12$ & 02096846 & Piedmont, rural & 7.54 & 17 & 69.8 & 4.44 & 0.3 & $08 / 21 / 2012$ & $08 / 22 / 2016$ \\
\hline $\mathrm{TC} 15$ & 02097464 & Piedmont, rural & 8.35 & 19.3 & 69.3 & 5.27 & 0.44 & $08 / 21 / 2016$ & $08 / 25 / 2016$ \\
\hline $\mathrm{TC} 17$ & 0209782609 & Piedmont, urban & 11.9 & 9.31 & 38.2 & 38.7 & 10.2 & $10 / 25 / 2011$ & $08 / 25 / 2016$ \\
\hline \multicolumn{10}{|c|}{ Copper (EPA parameter code 01042), in micrograms per liter } \\
\hline TC15 & 02097464 & Piedmont, rural & 8.35 & 19.3 & 69.3 & 5.27 & 0.44 & $04 / 19 / 1995$ & $04 / 14 / 2003$ \\
\hline $\mathrm{TC} 17$ & 0209782609 & Piedmont, urban & 11.9 & 9.31 & 38.2 & 38.7 & 10.2 & $10 / 30 / 2003$ & $12 / 23 / 2014$ \\
\hline $\mathrm{TC} 17$ & 0209782609 & Piedmont, urban & 11.9 & 9.31 & 38.2 & 38.7 & 10.2 & $10 / 30 / 2003$ & $10 / 23 / 2014$ \\
\hline
\end{tabular}


Table 8. Water-quality transport-curve statistics for selected constituents at 27 U.S. Geological Survey (USGS) streamgages in North Carolina.-Continued

[All transport curves were developed by using the common logarithms of stormflow (in cubic feet per second per square mile) as the explanatory variable and concentration (in the noted units) as the dependent variable. Equation parameters are presented in logarithmic (base 10) form. Rural basins are defined as having impervious area less than 10 percent. Urban basins are defined as having impervious area great than or equal to 10 percent. Mixed basins have less than 10 percent impervious area, but developed area is 20 percent or more of the basin, possibly reflecting transition from rural to urban. Shaded cells indicate transport curves that were selected to represent low, medium, or high ranges of concentration levels for the purposes of the water-quality simulations presented in this report. NLCD, National Land Cover Database; EPA, U.S. Environmental Protection Agency; mi $^{2}$, square mile; MAD, median absolute deviation; MaxX, maximum measured flow for both one- and two-segment transport curves; n/a, not applicable; WWTP, wastewater treatment plant]

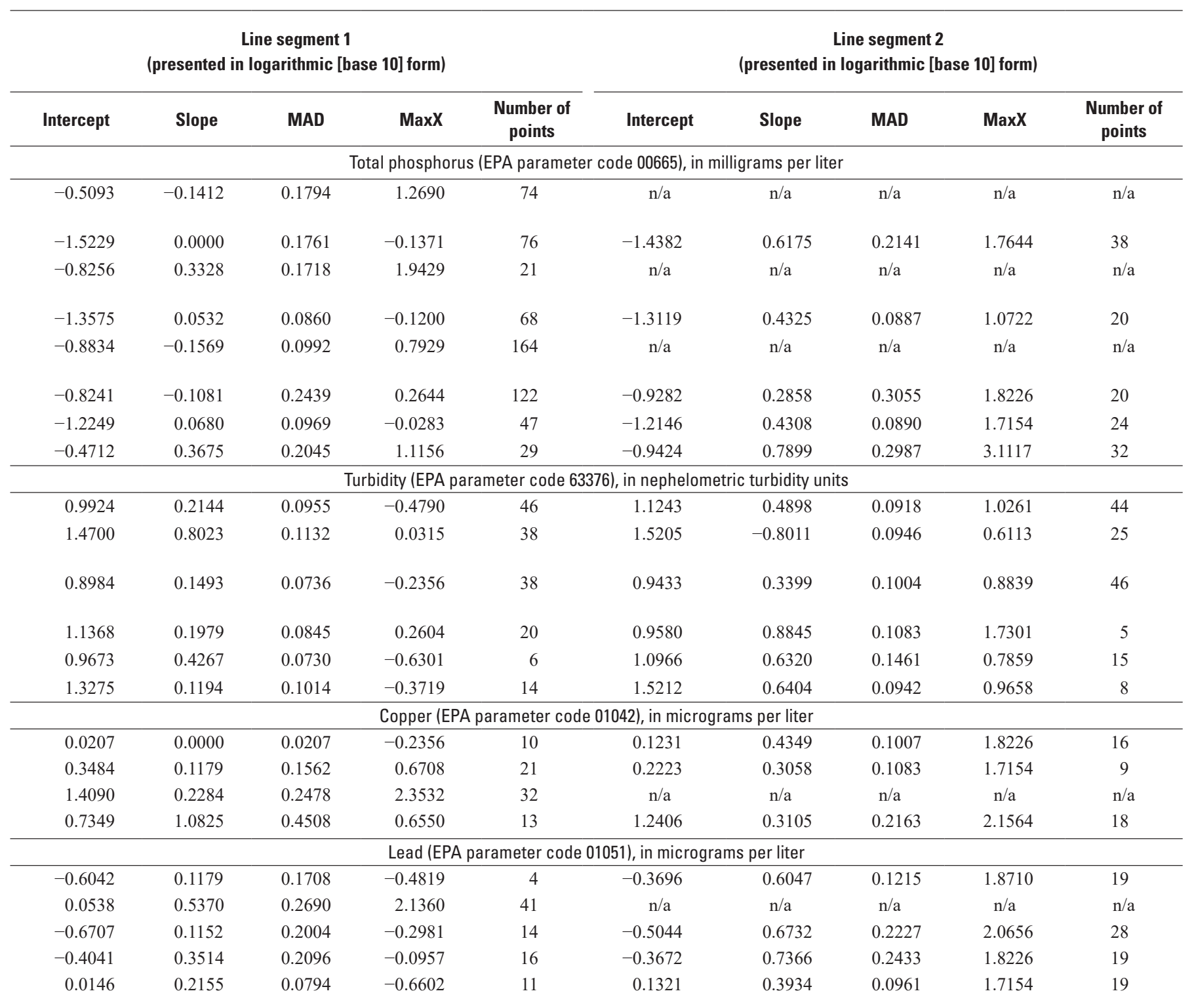


Table 8. Water-quality transport-curve statistics for selected constituents at 27 U.S. Geological Survey (USGS) streamgages in North Carolina.-Continued

[All transport curves were developed by using the common logarithms of stormflow (in cubic feet per second per square mile) as the explanatory variable and concentration (in the noted units) as the dependent variable. Equation parameters are presented in logarithmic (base 10) form. Rural basins are defined as having impervious area less than 10 percent. Urban basins are defined as having impervious area great than or equal to 10 percent. Mixed basins have less than 10 percent impervious area, but developed area is 20 percent or more of the basin, possibly reflecting transition from rural to urban. Shaded cells indicate transport curves that were selected to represent low, medium, or high ranges of concentration levels for the purposes of the water-quality simulations presented in this report. NLCD, National Land Cover Database; EPA, U.S. Environmental Protection Agency; mi $^{2}$, square mile; MAD, median absolute deviation; MaxX, maximum measured flow for both one- and two-segment transport curves; n/a, not applicable; WWTP, wastewater treatment plant]

\begin{tabular}{|c|c|c|c|c|c|c|c|c|c|}
\hline \multirow{2}{*}{$\begin{array}{c}\text { USGS } \\
\text { transport curve } \\
\text { site index number } \\
\text { (fig. 8) }\end{array}$} & \multirow{2}{*}{$\begin{array}{c}\text { USGS } \\
\text { streamgage } \\
\text { number }\end{array}$} & \multirow{2}{*}{$\begin{array}{l}\text { EPA Level III ecoregion, } \\
\text { general basin description }\end{array}$} & \multirow{2}{*}{$\begin{array}{l}\text { Drainage } \\
\text { area, } \mathrm{mi}^{2}\end{array}$} & \multicolumn{4}{|c|}{$\begin{array}{c}\text { USGS StreamStats } \\
2011 \text { NLCD } \\
\text { land cover percentages }\end{array}$} & \multicolumn{2}{|c|}{ Collection period range } \\
\hline & & & & $\begin{array}{l}\text { Crop/ } \\
\text { hay }\end{array}$ & Forest & Developed & $\begin{array}{l}\text { Impervious } \\
\text { area }\end{array}$ & Start date & End date \\
\hline \multicolumn{10}{|c|}{ Zinc (EPA parameter code 01092), in micrograms per liter } \\
\hline TC2 & 02085000 & Piedmont, rural & 66 & 24.3 & 54.9 & 12.5 & 2.23 & $03 / 20 / 1996$ & $10 / 23 / 2014$ \\
\hline $\mathrm{TC} 22$ & 02142651 & Piedmont, urban & 2.35 & 3.2 & 11.2 & 83.5 & 26.8 & $01 / 14 / 1995$ & 07/23/1997 \\
\hline
\end{tabular}

${ }^{1}$ Water-quality transport curves for sites TC19, TC4, and TC20 (fig. 10) were selected to simulate the low, medium, and high ranges, respectively, of event mean suspended sediment concentrations for the upstream basin.

${ }^{2}$ Water-quality transport curves for sites TC27, TC24, and TC6 (fig. 11) were selected to simulate the low, medium, and high ranges, respectively, of total nitrogen event mean concentrations for the upstream basin.

${ }^{3}$ Water-quality transport curves for sites TC4, TC15, and TC24 (fig. 12) were selected to simulate the low, medium, and high ranges, respectively, of total phosphorus event mean concentrations for the upstream basin. 
Table 8. Water-quality transport-curve statistics for selected constituents at 27 U.S. Geological Survey (USGS) streamgages in North Carolina.-Continued

[All transport curves were developed by using the common logarithms of stormflow (in cubic feet per second per square mile) as the explanatory variable and concentration (in the noted units) as the dependent variable. Equation parameters are presented in logarithmic (base 10) form. Rural basins are defined as having impervious area less than 10 percent. Urban basins are defined as having impervious area great than or equal to 10 percent. Mixed basins have less than 10 percent impervious area, but developed area is 20 percent or more of the basin, possibly reflecting transition from rural to urban. Shaded cells indicate transport curves that were selected to represent low, medium, or high ranges of concentration levels for the purposes of the water-quality simulations presented in this report. NLCD, National Land Cover Database; EPA, U.S. Environmental Protection Agency; $\mathrm{mi}^{2}$, square mile; MAD, median absolute deviation; MaxX, maximum measured flow for both one- and two-segment transport curves; n/a, not applicable; WWTP, wastewater treatment plant]

\begin{tabular}{|c|c|c|c|c|c|c|c|c|c|}
\hline \multicolumn{10}{|c|}{ Zinc (EPA parameter code 01092), in micrograms per liter } \\
\hline 0.5080 & 0.1706 & 0.1185 & -0.2990 & 10 & 0.5985 & 0.4734 & 0.2267 & 2.1405 & 17 \\
\hline 1.9766 & 0.1136 & 0.1640 & 2.3532 & 35 & $\mathrm{n} / \mathrm{a}$ & $\mathrm{n} / \mathrm{a}$ & $\mathrm{n} / \mathrm{a}$ & $\mathrm{n} / \mathrm{a}$ & $\mathrm{n} / \mathrm{a}$ \\
\hline
\end{tabular}


North Carolina, within the Piedmont ecoregion. The data and regression line indicate that suspended sediments increase gradually with increasing flow and vary substantially during low-flow periods (flows below about $0.32\left[\mathrm{ft}^{3} / \mathrm{s}\right] / \mathrm{mi}^{2}$ ).

Figure $9 B$ shows the results of an example SELDM simulation using the transport curve. Most simulated storm volumes are within the range of the second segment; only two randomly generated extreme-flood flows are simulated, producing large but plausible sediment concentrations.

Three of the water-quality transport curves developed for TN are for streamgages (fig. 8, sites TC6, TC13, and TC14) where flows are affected by upstream point-source discharges from WWTPs. Slopes for the relations at these streamgages were negative (table 8), indicating TN concentrations are higher in the lower (base flow) ranges of discharge, with concentration levels decreasing with increasing discharge levels. This pattern is likely reflective of the nitrogen levels within the point-source discharges from the upstream WWTPs. In a USGS study of water quality in Gwinnett County, Georgia, Landers and others (2007) documented a strong correlation between TN yield and base flow for three streams where streamflows contain treated wastewater. The high concentrations noted for the low discharge ranges in the North Carolina transport curves for sites TC6, TC13, and TC14 (streamgages downstream from WWTP influences) echo the observations from Landers and others (2007), indicating increased dilution of TN with increased discharge.

Two of the water-quality transport curves developed for TP (sites TC1 and TC10) had slopes that were negative through the range of discharges (table 8), indicating higher TP concentrations in the lower ranges of discharge, with concentration levels decreasing with increasing discharge levels. Both of these streamgages are in the Middle Atlantic Coastal Plain (fig. 8) and have greater than 40 percent agricultural land use within the basin. In the Middle Atlantic Coastal Plain, it is a common practice to artificially drain channels in agricultural areas by placing underdrains beneath fields. The presence of underdrains may result in base-flow discharge of nutrients and (or) dilution of TP in the high discharge ranges.

A third water-quality transport curve for TP at a Piedmont streamgage (site TC15; fig. 8) demonstrated an initial negative slope and a positive slope in the high ranges of discharge (table 8). This pattern suggests an initial range of phosphorus dilution in the lower ranges of increasing discharge, similar to that noted for TN at three streamgages with WWTP effects in the streamflows (dilution). The relation shifts to a positive slope at discharges corresponding to about $1.8\left(\mathrm{ft}^{3} / \mathrm{s}\right) / \mathrm{mi}^{2}$ or higher, indicating higher phosphorus concentrations in the runoff from the land surface that would be associated with the larger storm flows (washoff). The cause of phosphorus dilution in the lower ranges of discharge is presently unknown.

Of note, the TP water-quality transport curve developed in this study for site TC4 (USGS sta. 0208524090; table 8) is practically identical to that developed by Granato and Jones (2015) for the same site in a study on TP EMCs simulated by
SELDM. In that study, Granato and Jones (2015) evaluated the potential implications of using median in-stream concentration values with macroinvertebrate health ratings to set target nutrient concentrations by ecoregion, termed the Water Quality Assessed by Benthic macroinvertebrate health ratings (WQABI) method by McNett and others (2010). Granato and Jones (2015) used the SELDM-simulated EMCs for TP for this site to exemplify that the WQABI method, which was developed on the basis of base-flow samples, would not reflect water quality during stormflows.

One of the water-quality transport curves for turbidity likewise exhibited both positive and negative slopes (table 8). This relation is characterized by increasing turbidity with increasing discharge but decreasing turbidity for discharge yields of about $1.0(\mathrm{ft} 3 / \mathrm{s}) / \mathrm{mi} 2$ or higher. This streamgage (site TC9; fig. 8) has the largest drainage area for which a transport curve was developed, and the basin drains both Piedmont and Middle Atlantic Coastal Plain ecoregions. The initial positive slope suggests increasing turbidity in the lower ranges of increasing stormflow caused by initial washoff of sediment and sediment-laden constituents from the upstream basin. However, as the stormflow continues to increase, the turbidity reaches a peak and begins to decline because of dilution arising from continually increasing streamflow carrying decreased available constituents (commonly known as sediment exhaustion). This pattern is similar to that noted for the levels of water-quality constituents in streamflow below a WWTP.

The transport curves developed for the three metal constituents had positive slopes for all discharge ranges. Two of the four transport curves for copper (sites TC22 and TC23; fig. 8) and one of the transport curves for zinc (site TC22) produce concentrations almost a magnitude higher than concentrations calculated with the remaining two (copper) or three (zinc) relations (table 8). The high ranges of discharge associated with these three transport curves suggest that sampling was focused on stormflow runoff at those sites; the larger ranges of discharge for the remaining transport curves reflects sampling in both the base-flow and stormflow ranges. Additionally, the streamgages associated with these three relations are in Mecklenburg County, North Carolina, near the Charlotte metropolitan area, a region that has undergone rapid development over the last several decades. In a Massachusetts study, Granato and Jones (2017a) used SELDM to demonstrate multiple scenarios of copper concentrations from a large urban area, with one scenario not including highway runoff or BMP effluent. In that scenario, the SELDM output indicated runoff from the large urban area caused copper exceedances in the receiving stream in 2.24 percent of runoff events. However, in another scenario that included the effects of urban and highway runoff, neither the highway runoff nor the BMP effluent from the highway site increased the percentage of copper exceedances in the receiving stream above that caused by the upstream development (Granato and Jones, 2017a). Therefore, these simulations indicated that transport curves with larger metal concentrations may result from the effects of runoff from developed areas in the basins. 


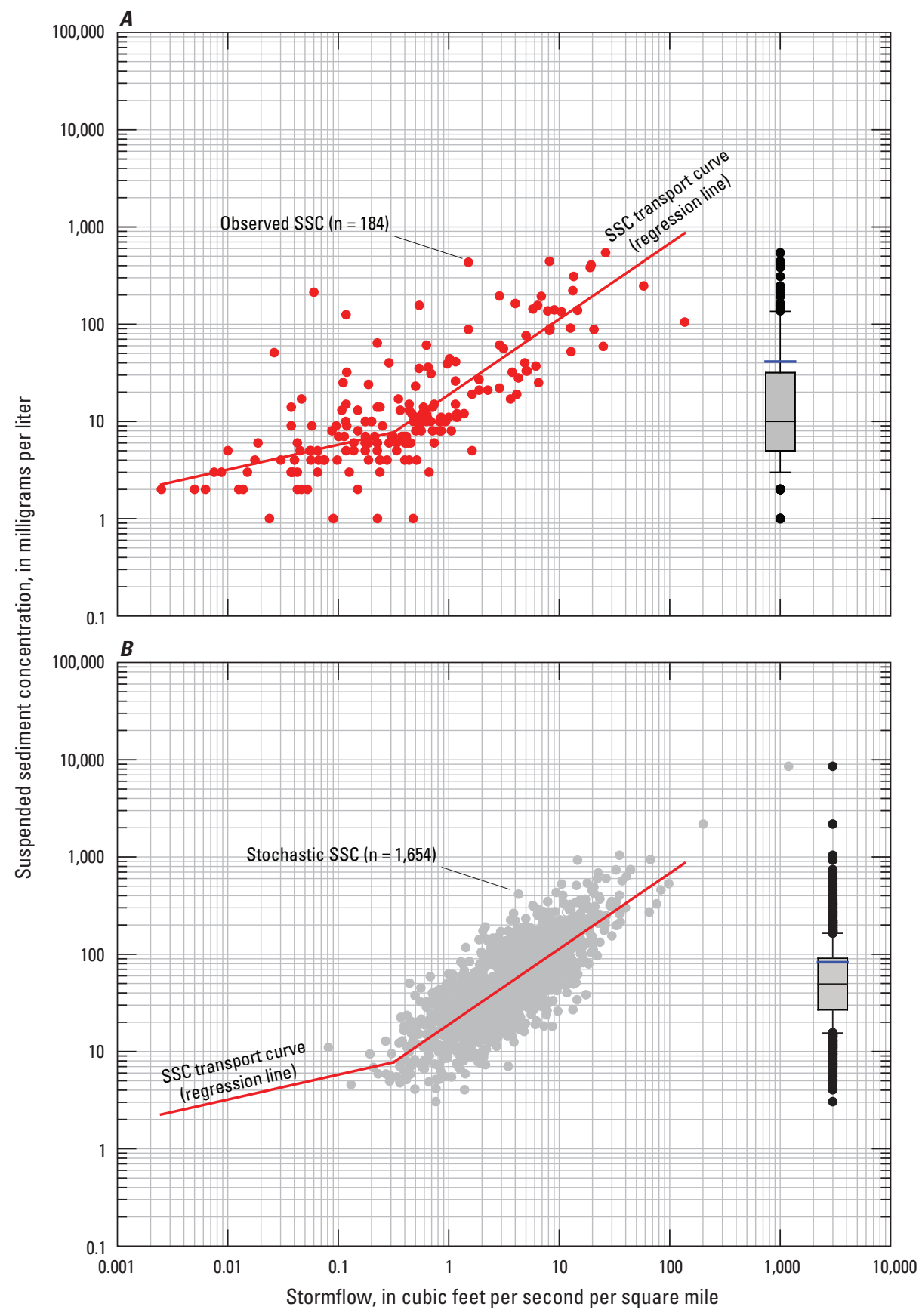

\section{EXPLANATION}

- Outlier

丁 90th percentile

- Mean

75th percentile

50th percentile (median)

25th percentile

$\perp$ 10th percentile

- Outlier

Figure 9. Graphs showing examples of $(A)$ development and $(B)$ use of a two-segment water-quality transport curve for stochastic generation of suspended sediment concentration (SSC) for site TC4 (U.S. Geological Survey station 0208524090; table 8, fig. 8). 
To test the potential effect of SELDM simulations that result in extrapolation of the transport curves, a set of upstream-basin stormflows (in $\left([\mathrm{ft} / \mathrm{s}] / \mathrm{mi}^{2}\right)$ for a $10-\mathrm{mi}^{2}$ Piedmont basin were stochastically generated in SELDM and used to predict the concentrations on the basis of the equation parameters. Observed concentrations for each of the six constituents and turbidity were downloaded from the Surface Water Quality Data Miner database (SWQDM; appendix 4 in Granato and others, 2009) for each of the four EPA Level III ecoregions within North Carolina (fig. 4). The maximum observed concentration of each constituent by ecoregion was compared to the maximum predicted concentration from each water-quality transport curve. Example results of this analysis showing large concentrations that are associated with two very large simulated flow values are shown in figure $9 B$. Figures 10-12, respectively, show the ranges of predicted EMCs for SSC, TN, and TP, the three constituents used for water-quality simulations presented in subsequent sections of this report. SELDM uses stochastic methods to generate a wide range of stormflows and therefore concentrations. The concentrations that are generated must be evaluated within the context of physicochemical limits associated with each constituent. For example, sediment concentrations on the order of magnitude of 1,000,000 milligrams per liter $(\mathrm{mg} / \mathrm{L})$ occur in the southwestern United States but would not be expected to occur in North Carolina (in the absence of wildfires, landslides, or improperly managed development). Risley and Granato (2014) discussed possibilities for generating extreme values and noted that although there are solubility limits for purely dissolved constituents carried within sediment-laden streamflows, concentrations of whole water (total) constituents are not so limited because concentrations associated with the sediment phase of a whole water sample can be large.

The ranges of available concentrations typically are very limited in terms of spatial distribution and the numbers of samples that have been collected over the range of potential flows at many sites. Therefore, the maximum recorded concentrations available in the SWQDM (Granato and others, 2009) for each constituent were used to evaluate the concentrations produced by each transport curve when flows were extrapolated beyond the available data. For SSC, maximum predicted concentrations exceeded the maximum observed concentrations for 3 of 18 water-quality transport curves (sites TC25, TC26, and TC27 in fig. 10). Maximum concentrations simulated for TN exceeded the maximum observed concentrations for 2 of 12 water-quality transport curves (sites TC6 and TC27 in fig. 11). For TP, the maximum simulated concentrations exceeded the maximum observed concentrations for one of eight water-quality transport curves (site TC24 in fig. 12). SELDM simulates a set of widely varying runoff-producing events that may occur over a random 20- to 40 -year period because few if any actual streamflow datasets are this comprehensive where simulation results reflect the effects of extrapolation from smaller datasets. Although SELDM generates about 30 years of record, the random-number generator can produce more extreme events than would be expected within the simulation. However, this behavior is similar to actual data records; for example, the 100-year flood can occur within the first year of a monitoring program. Although extreme concentrations and flows do not have an important effect on the number of exceedances, they can have an inordinate effect on long-term average annual yields. Users should examine the values generated from the simulations and apply appropriate judgements in the interpretations and use of such output. Users can include an additional upper segment with a zero slope and an appropriate MAD value to minimize the effects of extrapolation when simulating receiving waters by using a transport curve. This method is consistent with the sediment-exhaustion theory, which indicates that an upper bound to transport curves occurs when high flows exhaust erodible sources of suspended constituents. 


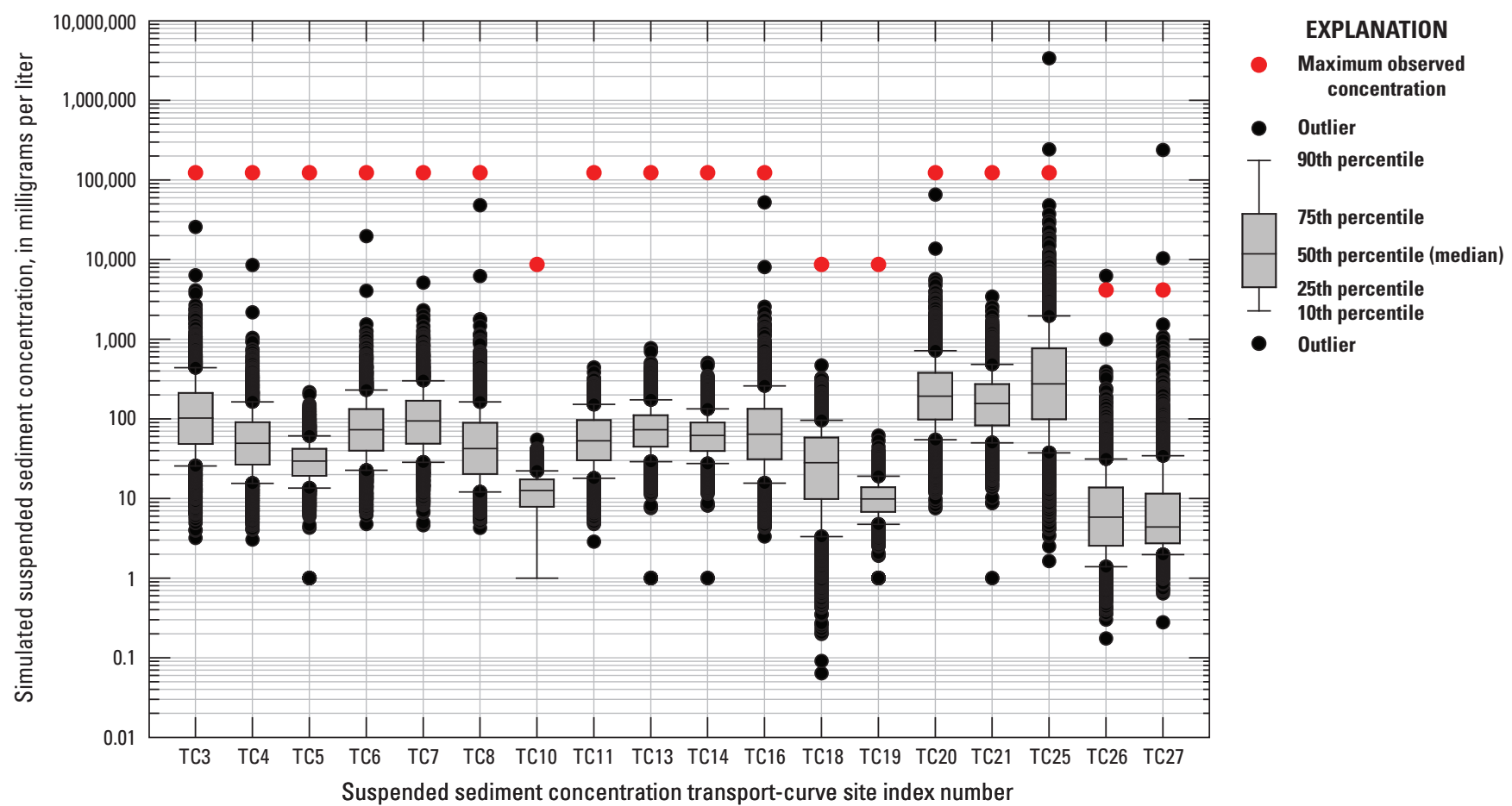

Figure 10. Boxplots showing ranges in simulated suspended sediment concentrations among 18 water-quality transport curves developed for the North Carolina Stochastic Empirical Loading and Dilution Model study. Maximum observed concentrations are from the Surface Water Quality Data Miner (Granato and others, 2009). Site index numbers and transport-curve statistics are listed in table 8.

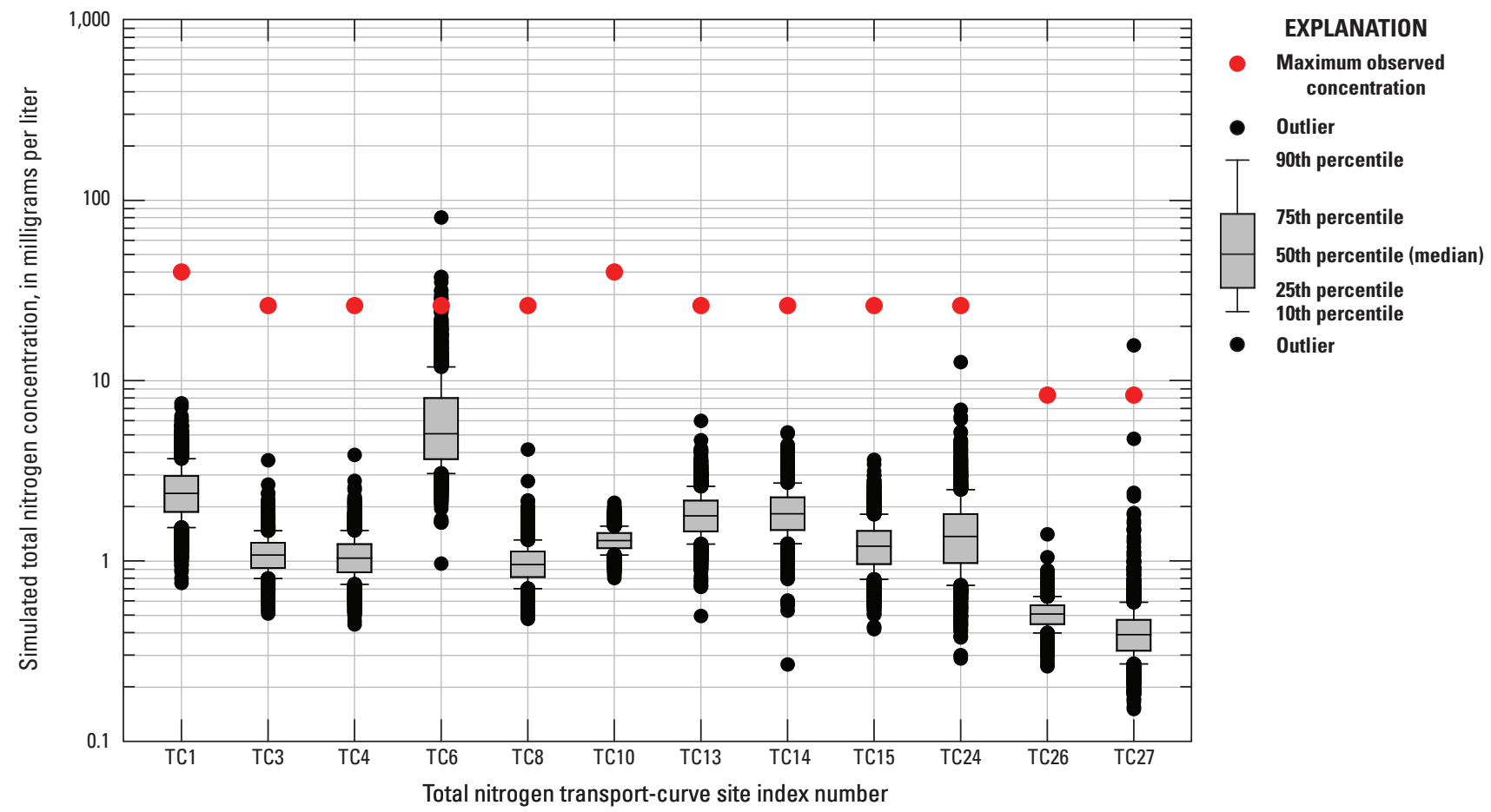

Figure 11. Boxplots showing ranges in simulated total nitrogen concentrations among 12 water-quality transport curves developed for the North Carolina Stochastic Empirical Loading and Dilution Model study. Maximum observed concentrations are from the Surface Water Quality Data Miner (Granato and others, 2009). Site index numbers and transport-curve statistics are listed in table 8. 


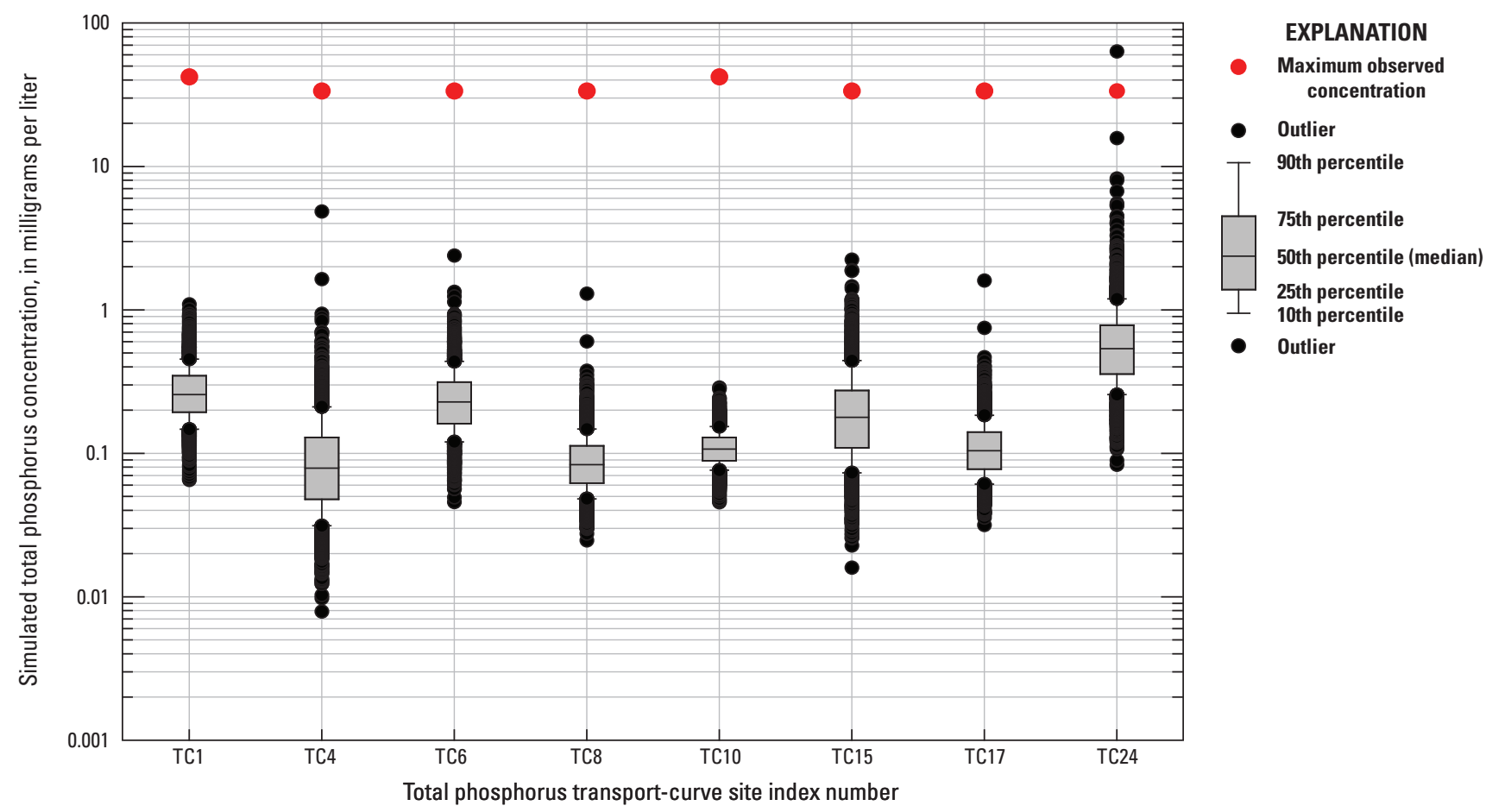

Figure 12. Boxplots showing ranges in simulated total phosphorus concentrations among eight water-quality transport curves developed for the North Carolina Stochastic Empirical Loading and Dilution Model study. Maximum observed concentrations are from the Surface Water Quality Data Miner (Granato and others, 2009). Site index numbers and transport-curve statistics are listed in table 8.

\section{Simulating Highway-Runoff Treatment}

SELDM simulates highway-runoff treatment stochastically by using statistics for flow reduction, hydrograph extension, and concentration reduction by structural stormwater control measure BMPs (Granato 2013; 2014). Flow reduction occurs when stormwater is infiltrated or is retained and then lost through evapotranspiration. However, flow reduction statistics indicate that outflows can exceed inflows during some events if there is groundwater discharge or carry-over discharge from a previous storm event. Flow reduction reduces the load of highway runoff and therefore can decrease the downstream concentrations (if the highway concentration is greater than the upstream concentration). Hydrograph extension occurs when the BMP slows the discharge of stormflows. By design, hydrograph extension can increase dilution in receiving waters by extending the duration of runoff from the highway site so that it is more concurrent to upstream stormflow. If the highway concentration is greater than the upstream concentration, then hydrograph extension increases dilution and therefore decreases the downstream concentrations. Concentration reduction occurs when a physical, chemical, or biological process alters the concentration of runoff as stormflow passes through the BMP. However, concentration-reduction statistics also indicate that outflow concentrations can exceed inflow concentrations during some events. Many processes could cause an increase in outflow concentrations. For example, high flows may scour previously deposited sediments. BMPs do not produce distilled water; they have treatment limits, which are commonly known as the minimum irreducible concentrations (MICs).

SELDM uses the trapezoidal distribution and the rank correlation with the associated highway-runoff variable as a stochastic transfer function to simulate the quantity and quality of BMP effluent given the associated inflow values for each storm event (Granato, 2013, 2014). Granato (2014) documented the methods and techniques to use the trapezoidal distribution to evaluate BMP performance statistics. In the current North Carolina study, these techniques were used to fit the efficiency ratios (outflow divided by inflow) of stormwater runoff and quality for selected constituents to the trapezoidal distribution. The trapezoidal distribution was selected for BMP analysis because it provides a bounded and flexible curvilinear cumulative distribution function that can be used to simulate BMP performance (fig. 13). Figure 13 shows distribution functions for TSS BMP performance data from individual sites in North Carolina, the median of the North Carolina sites, and the median of the national dataset documented by Granato (2014). The graph shows large variations in statistics between sites and demonstrates the robust approach of using the median of individual statistics to generate a representative distribution. Rank correlation between variables is used to simulate relations between inflow and outflow data commonly found in BMP studies. For example, figure 13 indicates that a substantial number of generated ratios would be larger than 1 for several of the datasets. Because the BMP concentrations 
are negatively correlated to inflow concentrations, ratios greater than 1 are likely to be paired with low inflow concentrations. Granato (2014) noted that BMPs such as grass swales can increase loads of some constituents when inflow concentrations are very low. In SELDM, any statistically generated BMP outflow concentrations below the MIC is set equal to the MIC to represent this treatment limit.

Several studies (Granato and Jones, 2017; Smith and others, 2018; Stonewall and others, 2018) have used the median of treatment statistics from nine BMP categories calculated by Granato (2014) to simulate a generic BMP. Using the median of statistics from the nine categories is appropriate because variations in within-category statistics among the BMP sites analyzed are as large as the variations in statistics between categories. Furthermore, it is unlikely that the same type of BMP will be used for every stormwater outfall within a stream basin or across the State. National medians (by BMP type; Granato, 2014) of flow-reduction and hydrograph-extension are shown in table 9, and concentration-reduction statistics for selected constituents are shown in table 10. The bioretention, composite BMPs, detention basins, biofilters (swales), media filters, retention ponds, wetland basins, and wetland channels categories were selected because flow statistics, concentration statistics, and MIC statistics were available from multiple BMP monitoring sites for these categories (Granato, 2014). The MIC values that were chosen for these simulations were based on the 25th percentile of MIC estimates from available sites for each category.

The national medians can be used in SELDM for analyses if site-specific, local, or regional BMP performance statistics are not available. For example, North Carolina-based BMP performance data were not available for SSC; however, national BMP performance statistics for SSC are available. Granato (2014) developed performance statistics for SSC by using TSS data in the International Stormwater BMP Database (accessible at http://www.bmpdatabase.org/). Estimates of SSC performance were needed because many studies have shown that TSS is an unreliable measure of sediment if sand-size particles are present (Gray and others, 2000; Guo, 2006; Landers and others, 2007; Ying and Sansalone, 2008; Guo and MacKenzie, 2013) and because there are very few SSC samples in the International Stormwater BMP Database. Estimates of inflow concentrations of SSC were developed by using available TSS concentrations and the relation between TSS and SSC in highway runoff developed by Granato and Cazenas (2009). Estimates of outflow concentrations of SSC were developed by assuming that SSC values would converge to TSS concentrations because most BMPs could remove the coarse sediment fractions that cannot be effectively measured by using TSS measurement methods. This assumption is supported by studies showing that SSC and TSS values tend to converge as the percentage of large-diameter particles decreases (Gray and others, 2000; Guo, 2006).

Performance data for only three BMP types - grass strip or swale, bioretention, and wetland channel -were available from the NCDOT research data. These data were incorporated into the North Carolina-enhanced SELDM for flow (or volume) reduction and treatment of four water-quality constituents (TSS, TN, TP, and nitrate plus nitrite) and turbidity. Analyses were completed by assessing the efficiency ratios (outflow divided by inflow) of the samples collected for stormflow runoff and the selected constituents. The International Stormwater BMP Database (Wright Water Engineers, Inc. and Geosyntec Consultants, 2016) defines a grass strip or swale - sometimes called a biofilter - as a vegetated area designed to accept sheet flow, where the primary mechanisms for pollutant removal are filtration, infiltration, and settling. Bioretention BMPs are landscaping features that provide water-quality treatment through filtering of stormwater runoff and allowing vegetation uptake of nutrients (Charlotte-Mecklenburg Stormwater Services, 2013). A wetland channel (also known as a rain garden) is designed to support dense wetland vegetation on its bottom and to convey flow very slowly (Wright Water Engineers, Inc. and Geosyntec Consultants, 2016).

Among the seven research reports for which North Carolina highway and bridge deck runoff water-quality datasets were uploaded into the HRDB, five reports included BMP data that could be used to evaluate BMP performance and to generate statistics for inclusion in the North Carolinaenhanced SELDM (table 5). These datasets are HRDB datasets 16 (Line, 2006), 18 (Luell and others, 2012), 19 (Winston and others, 2011), 20 (Wu and Allan, 2013), and 21 (Wu and Allan, 2014). HRDB datasets 15 (Wu and Allan, 2001) and 17 (Wagner and others, 2011) were not included in the BMP analyses for this study because no BMP sampling was done as part of those research studies.

The BMP analyses were completed by using a trapezoidal curve-fitting process that used the efficiency ratios for a given highway-runoff and BMP site pair (Granato, 2014). For each site pair analyzed, the efficiency ratios were modeled by using the trapezoidal distribution, which can be parameterized by fitting the distribution to data. The trapezoidal distribution is bounded by selected minimum and maximum values and is further defined by the lower and upper most probable values (efficiency ratios). For each North Carolina site where these four trapezoidal distribution statistics were determined, the squared residual and Spearman's rho were determined and summarized because these two statistics are also SELDM inputs for the BMP analyses.

The medians of the four trapezoidal statistics, squared residual, and Spearman's rho were determined for the North Carolina sites (by BMP type) and compared to the confidence intervals determined for medians of the national BMP study statistics (Granato, 2014). If the North Carolina medians fell outside the range of the confidence intervals, such values were characterized as being statistically different from the medians of the national statistics. Confidence intervals of the national study statistics were determined only if there were eight or more sites in the national sample for a given constituent. A minimum sample size of eight was selected to match the smallest sample sizes listed in tables 5 and 6 of Granato (2014) for the constituents included in the national BMP study, thereby maintaining consistency in the North Carolina analyses of BMP performance data. 
For the concentration-ratio analyses, only those North Carolina highway-runoff and BMP site pairs that included a minimum of 10 efficiency ratios (outflow divided by inflow) were used for the trapezoidal-distribution fitting process. Using a minimum sample-count criterion of 10 establishes the uncertainty bounds needed to evaluate the quality of estimated statistics (Kacker and Lawrence, 2007; Lech and Maryna, 2009). None of the metals data (cadmium, copper, lead, and zinc) in HRDB datasets 16 and 18 met this sample-count criterion, so these data were eliminated from the analysis.

Some of the highway-runoff and BMP site pairs were noted as having a high percentage of efficiency ratios greater than or equal to 1 , raising concerns about (1) the true effectiveness of BMP treatments and (2) the effects of such data on the medians computed for the North Carolina SELDM sites. Efficiency ratios greater than 1 indicate that concentrations and (or) flows leaving a BMP are greater than the concentrations and (or) flows entering the BMP. In some cases, physicochemical processes can generate additional outputs, but ratios consistently greater than 1 raise data-integrity questions. For the purposes of this study, therefore, individual highway-runoff and BMP site pairs where the percentage of greater than or equal to 1 efficiency ratios was 70 percent or higher were not included in the analyses. It should be noted that removal of a given highway-runoff and BMP site pair did not result in the removal of the entire study from the BMP analyses. The occurrence of efficiency ratio values greater than 1 highlights the multiple factors that govern BMP treatment of highway runoff. Beyond the methods of measuring stormflow and the handling of waterquality samples, other factors include the design, installation, and ongoing maintenance required to enable effective treatment of highway runoff.

Where BMP treatment is ineffective, it may be challenging to identify the primary factor(s) behind the failure. Conlon and Journey (2008) evaluated the concentration reduction efficiencies of four structural BMP devices in Beaufort and Colleton Counties, South Carolina. Although the four BMP devices were efficient in reducing suspended sediment EMCs, they were not successful in significantly reducing fecal bacteria, nutrients, and total organic carbon (including the associated properties of biochemical oxygen demand and chemical oxygen demand). The BMPs tended to preferentially trap the sand-size fraction of sediment, thereby releasing a greater percentage of fine-grained (silt and clay) sediment from the BMP outlets. The preferential trapping of sand-size fraction sediment by the BMPs could explain, at least in part, why the BMPs were not successful at significantly reducing fecal bacteria, nutrients, and total organic carbon because these constituents tend to attach to the fine-grained fractions of sediment. Statistical correlation tests were unable to identify a single major factor that could explain the large variability in inlet and outlet concentrations and in removal efficiencies estimated by reduction percentage. The authors discussed the highly variable inlet and outlet concentrations for each BMP that had highly variable reduction percentages. These variations were probably the result of multiple interacting factors, particularly rainfall intensity, the amount of rainfall between sampling events, traffic density, and the time since the last maintenance (clean out) of the BMP device (Conlon and Journey, 2008).

The North Carolina medians presented for the volumereduction statistics and the concentration-ratio statistics for four water-quality constituents (TSS, TN, TP, nitrate plus nitrite) and turbidity (tables 11-16, respectively) were pre-loaded into the North Carolina-enhanced SELDM. Where site-specific North Carolina statistics are needed for in-depth SELDM simulations, users can input such statistics under the appropriate tabs within the "Best Management Practice Performance" input module of the North Carolina-enhanced SELDM. Users should refer to tables 11 through 16 for the site-specific BMP statistics for volume reduction ( 9 sites; table 11), turbidity ( 2 sites; table 12$)$, TSS (17 sites; table 13), TN (17 sites; table 14), TP (17 sites; table 15), and nitrate plus nitrite (17 sites; table 16). The North Carolina medians for MICs also were pre-loaded into the North Carolinaenhanced SELDM, and the site-specific MIC values are likewise provided in tables 11-16. It should be noted that all North Carolina medians were pre-loaded in the North Carolina-enhanced SELDM regardless of whether or not these determinations were within the confidence intervals of the national statistics.

\section{Volume Reduction}

For the BMP volume-reduction analyses, a total of 12 North Carolina SELDM sites (all grass swale BMP type) were available for analysis. Of these 12 sites, a total of 4 highway-runoff and BMP site pairs were removed because more than 70 percent of the efficiency ratios were greater than or equal to $1(71,91,96$, and 100 percent). In the national BMP study, Granato (2014) used one North Carolina site, for which data were obtained from the International Stormwater BMP Database. Efforts to cross reference this site to one of the 12 in the North Carolina SELDM study did not yield a positive confirmation, but this site (NC DOT Grass Strip) appears to be one of the BMP sites documented in HRDB dataset 18 (Luell and others, 2012) (table 5). Therefore, a total of nine sites were used to compute the North Carolina SELDM medians for minimum, lower bound of the most probable value (LBMPV), upper bound of the most probable value (UBMPV), and maximum volume-reduction statistics (table 11). Only one of the median statistics (minimum) was outside the 95-percent confidence interval of the median statistics for the national study sites (Granato, 2014) and thereby considered to be statistically different from the national median.

\section{Turbidity}

For the BMP concentration-ratio analyses for turbidity, a total of eight North Carolina SELDM sites (all grass swale BMP type) were available for analysis. Of these eight sites, a total of six highway-runoff and BMP site pairs were removed 


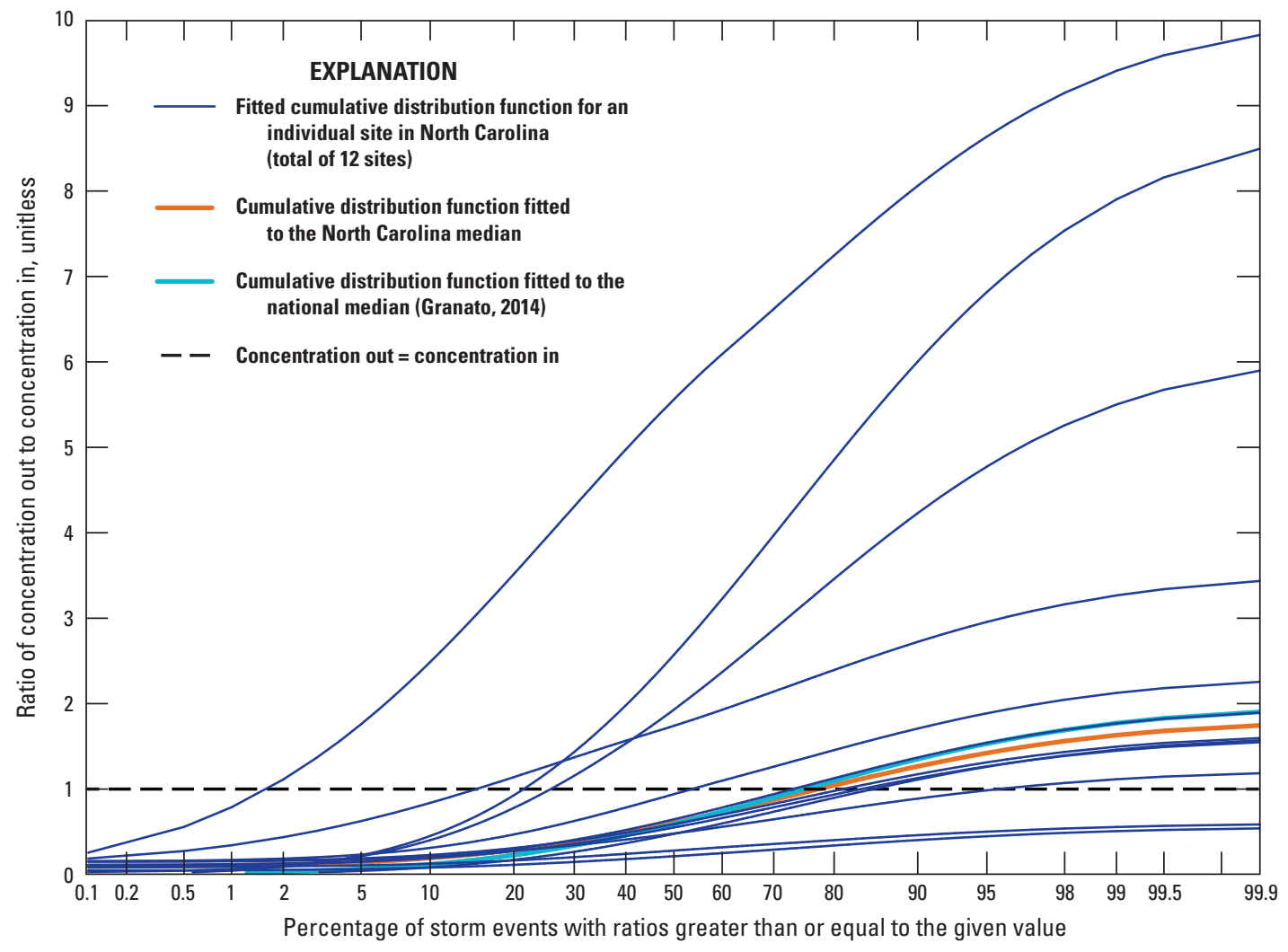

Figure 13. Graph showing fitted cumulative trapezoidal-distribution functions of the total suspended solids concentration-reduction statistics for grass swale best management practice (BMP) sites in North Carolina. The graph also shows cumulative distribution functions that are fitted to the North Carolina and national medians of the concentration-reduction statistics for grass swale BMPs (table 13). 
Table 9. Stormwater control measure best management practice (BMP) performance flow-reduction and hydrograph-extension statistics for sites throughout the United States.

[Statistics are adapted from tables 2 and 3 in Granato (2014). Sites with data for at least three storm events were used to calculate the median statistics. The flowreduction statistics are for the trapezoidal distribution of the ratio of outflow volume to inflow volume, which is unitless. The hydrograph-extension statistics are for the trapezoidal distribution of the duration of outflows that exceed the duration of inflows, in hours. LBMPV, lower bound of the most probable value; UBMPV, upper bound of the most probable value; --, insufficient data]

\begin{tabular}{|c|c|c|c|c|c|c|}
\hline \multirow{2}{*}{ BMP type } & \multirow{2}{*}{$\begin{array}{c}\text { Number } \\
\text { of } \\
\text { sites }\end{array}$} & \multicolumn{5}{|c|}{ Flow-reduction statistics } \\
\hline & & Minimum & LBMPV & UBMPV & Maximum & Spearman's rho ${ }^{1}$ \\
\hline \multicolumn{7}{|c|}{ Volume-reduction statistics } \\
\hline Bioretention & 8 & 0 & 0.019 & 0.152 & 0.947 & 0.61 \\
\hline Composite & -- & -- & -- & -- & -- & -- \\
\hline Detention basin & 13 & 0.147 & 0.147 & 0.657 & 1.232 & 0.07 \\
\hline Infiltration basin & -- & -- & -- & -- & -- & -- \\
\hline Media filter & 4 & 0.113 & 0.742 & 0.742 & 1.262 & 0 \\
\hline Retention pond & 31 & 0.208 & 0.665 & 0.903 & 1.832 & 0 \\
\hline Wetland basin & 6 & 0.136 & 0.934 & 0.934 & 1.233 & 0.21 \\
\hline \multicolumn{7}{|c|}{ Stormflow-extension statistics, in hours } \\
\hline Bioretention & -- & -- & -- & -- & -- & -- \\
\hline Composite & -- & -- & -- & -- & -- & -- \\
\hline Detention basin & 12 & 0 & 0 & 0 & 18 & 0.42 \\
\hline Biofilter (grass swale) & 11 & 0 & 0 & 0 & 3 & 0.04 \\
\hline Infiltration basin & -- & -- & -- & -- & -- & -- \\
\hline Media filter & 4 & 0 & 0 & 0 & 77 & 0.41 \\
\hline Retention pond & 10 & 0 & 0 & 0 & 40 & 0.3 \\
\hline Wetland basin & 3 & 0 & 0 & 0 & 8 & 0.15 \\
\hline Wetland channel & -- & -- & -- & -- & -- & -- \\
\hline
\end{tabular}

'The Spearman's rho correlation coefficients are the median values presented in tables 2 and 3 in Granato (2014). The coefficients for flow reduction were calculated by using the ranks of the inflows and the associated ranks of the ratios of outflows to inflows. The coefficients for hydrograph extension were calculated by using the ranks of the inflow durations and the associated ranks of extension durations 
Table 10. Stormwater control measure best management practice (BMP) performance concentration-reduction statistics for sites throughout the United States.

[Statistics are adapted from table 5 in Granato (2014). Sites with paired inflow and outflow concentrations for at least seven storms were used to calculate the median statistics. The concentration-reduction statistics are for the trapezoidal distribution of the ratio of outflow to inflow concentrations. LBMPV, lower bound of the most probable value; UBMPV, upper bound of the most probable value; MIC, minimum irreducible concentration; EPA, U.S. Environmental Protection Agency]

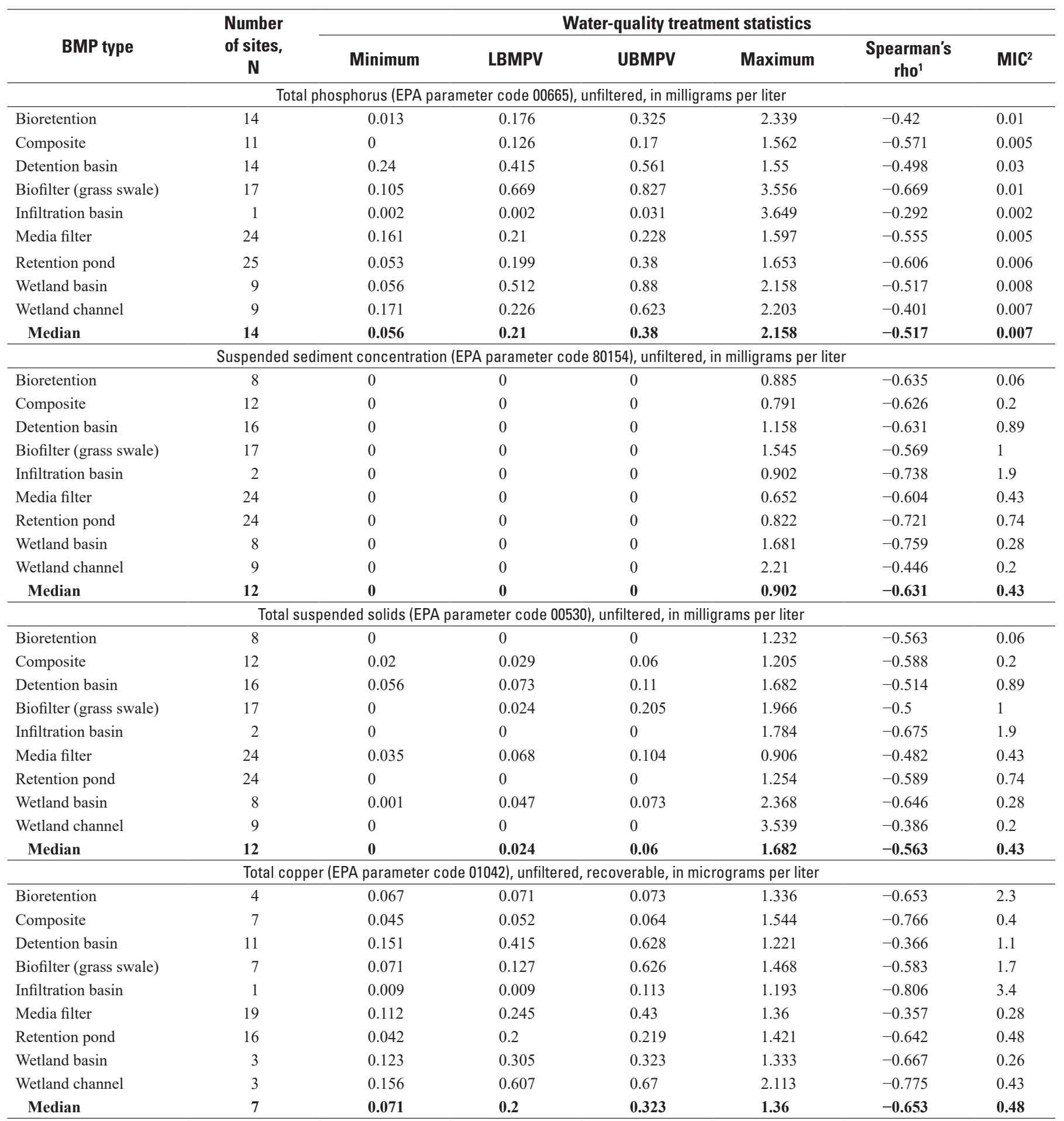

${ }^{1}$ The Spearman's rho correlation coefficients were calculated by using the ranks of the inflow concentrations and the associated ranks of the ratios of outflow to inflow concentrations.

${ }^{2}$ The MIC values chosen for the simulations were based on the 25th percentile of MIC estimates from available sites for each category. The MIC estimates for the suspended sediment concentrations were developed with total suspended solids concentrations, but are considered applicable for estimating the MIC of suspended sediment concentrations because differences in the results of these analytical methods are small once the large grain-size fractions are removed within the BMP. 
Table 11. Summary of stormflow volume-reduction statistics for the trapezoidal distribution for grass swale best management practice (BMP) sites from North Carolina Department of Transportation-partner highway-runoff studies.

[Efficiency ratio is outflow volume divided by inflow volume. Red shading indicates the North Carolina (NC) Stochastic Empirical Loading and Dilution Model (SELDM) median statistics are outside the range of the 95-percent confidence interval for the corresponding median statistics for the national study sites (Granato, 2014) and are thereby considered statistically different. HRDB, Highway-Runoff Database; LBMPV, lower bound of the most probable value; UBMPV, upper bound of the most probable value; I, Interstate; SR, Secondary Road; Rd, Road; HMA, hot-mix-asphalt; OGFC, open-graded friction course; n/a, not applicable; NCDOT, North Carolina Department of Transportation]

\begin{tabular}{|c|c|c|c|c|c|c|c|c|c|c|c|}
\hline \multirow{2}{*}{$\begin{array}{c}\text { HRDB } \\
\text { highway } \\
\text { dataset } \\
\text { number }\end{array}$} & \multirow{2}{*}{$\begin{array}{l}\text { HRDB } \\
\text { site } \\
\text { number } \\
\text { (fig. 8) }\end{array}$} & \multirow[b]{2}{*}{ Site } & \multirow[b]{2}{*}{ BMP type } & \multirow{2}{*}{$\begin{array}{c}\text { Number of } \\
\text { efficiency } \\
\text { ratio } \\
\text { samples }\end{array}$} & \multirow{2}{*}{$\begin{array}{c}\text { Ratio } \\
\geq 1 \\
\text { (percent) }\end{array}$} & \multicolumn{6}{|c|}{ Volume-reduction statistics } \\
\hline & & & & & & Minimum & LBMPV & UBMPV & Maximum & $\begin{array}{l}\text { Squared } \\
\text { residual }\end{array}$ & $\begin{array}{l}\text { Spearman's } \\
\text { Rho }\end{array}$ \\
\hline \multicolumn{12}{|c|}{ NC SELDM study sites (paired highway-runoff and BMP sampling locations) } \\
\hline 20 & 174 & NC I-77 Charlotte OGFC edge of pavement (Wu and Allan, 2013) & Filter strip & 19 & 15.8 & 0.3119 & 0.4524 & 1.0527 & 1.1265 & 0.0142 & 0.6585 \\
\hline 20 & 175 & $\begin{array}{l}\text { NC I-77 Charlotte control (HMA) edge of pavement } \\
\text { (Wu and Allan, 2013) }\end{array}$ & Filter strip & 15 & 20.0 & 0.7688 & 1.0406 & 1.0461 & 1.0461 & 0.0141 & 0.1482 \\
\hline 20 & 176 & NC I-85 Lexington OGFC edge of pavement (Wu and Allan, 2013) & Filter strip & 13 & 30.8 & 0.7221 & 0.7221 & 0.7221 & 1.2938 & 0.0091 & 0.4037 \\
\hline 20 & 177 & $\begin{array}{l}\text { NC I-85 Lexington control (HMA) edge of pavement } \\
\text { (Wu and Allan, 2013) }\end{array}$ & Filter strip & 17 & 17.6 & 0.6932 & 0.9254 & 0.9254 & 1.1530 & 0.0031 & 0.5330 \\
\hline 21 & 178 & NC SR 1717 Jordan Lake North swale influent (Wu and Allan, 2014) & Swale & 26 & 0.0 & 0.1044 & 0.1044 & 0.4712 & 0.6811 & 0.0443 & 0.5481 \\
\hline 21 & 179 & NC SR 1943 Jordan Lake South swale influent (Wu and Allan, 2014) & Swale & 30 & 3.3 & 0.1192 & 0.1192 & 0.4981 & 1.0181 & 0.0263 & 0.6164 \\
\hline 21 & 180 & NC SR 1360 Mountain Island Lake swale influent (Wu and Allan, 2014) & Swale & 26 & 0.0 & 0.0001 & 0.0001 & 0.0001 & 0.7565 & 0.0347 & 0.7927 \\
\hline 19 & 170 & $\begin{array}{l}\text { NC I-40 near Strickland Crossroads Rd swale influent (site A) } \\
\text { (Winston and others, 2012) }\end{array}$ & Swale & 27 & 0.0 & 0.0001 & 0.0001 & 0.0001 & 0.6503 & 0.0990 & 0.2992 \\
\hline \multicolumn{12}{|c|}{ Individual NC sites used in the national BMP study (Granato, 2014) } \\
\hline $\mathrm{n} / \mathrm{a}$ & $\mathrm{n} / \mathrm{a}$ & NC DOT Grass Strip & GS - Biofilter & 9 & $\mathrm{n} / \mathrm{a}$ & 0.4644 & 0.4644 & 0.9173 & 0.9805 & 0.0048 & 0.9000 \\
\hline \multicolumn{12}{|c|}{ Median statistics } \\
\hline & & NC SELDM plus NC national BMP study sites (listed above), $\mathrm{n}=9$ site & & & & 0.3119 & 0.4524 & 0.7221 & 1.0181 & 0.0142 & 0.5481 \\
\hline & & National study sites (table 2 in Granato [2014]), $\mathrm{n}=29$ sites & & & & 0.0602 & 0.3059 & 0.4948 & 1.0845 & 0.0295 & 0.2857 \\
\hline & & Lower $95 \%$ confidence interval (national study sites) & & & & 0.0017 & 0.0878 & 0.1632 & 0.9410 & & \\
\hline & & Upper $95 \%$ confidence interval (national study sites) & & & & 0.3059 & 0.7015 & 0.8422 & 1.3097 & & \\
\hline
\end{tabular}

${ }^{1}$ The HRDB QW highway dataset number is the "QWHighwayDataSet_ID" field in the HRDB that references the indicated highway-runoff research report. 
Table 12. Summary of turbidity water-quality treatment statistics for the trapezoidal distribution for grass swale best management practice (BMP) sites from North Carolina Department of Transportation-partner highway-runoff studies.

[Efficiency ratio is outflow turbidity reading divided by inflow turbidity reading. Minimum irreducible concentrations (MICs) were computed by using the log-triangular lower-bound estimator method developed by Scherer and others (2003), as described in Granato (2014). HRDB, Highway-Runoff Database; LBMPV, lower bound of the most probable value; UBMPV, upper bound of the most probable value; ntu, nephelometric turbidity unit; NC, North Carolina; SELDM, Stochastic Empirical Loading and Dilution Model; I, Interstate; SR, Secondary Road; HMA, hot-mix-asphalt; n/d, confidence interval not determined because sample size was less than eight (Granato, 2014)]

\begin{tabular}{|c|c|c|c|c|c|c|c|c|c|c|c|c|}
\hline \multirow{2}{*}{$\begin{array}{c}\text { HRDB } \\
\text { highway } \\
\text { dataset } \\
\text { number }\end{array}$} & \multirow{2}{*}{$\begin{array}{c}\text { HRDB } \\
\text { site } \\
\text { number } \\
\text { (fig. 8) }\end{array}$} & \multirow[b]{2}{*}{ Site } & \multirow[b]{2}{*}{$\begin{array}{l}\text { BMP } \\
\text { type }\end{array}$} & \multirow{2}{*}{$\begin{array}{c}\text { Number of } \\
\text { efficiency } \\
\text { ratio } \\
\text { samples }\end{array}$} & \multirow{2}{*}{$\begin{array}{c}\text { Ratio } \\
\geq 1 \\
\text { (percent) }\end{array}$} & \multicolumn{6}{|c|}{ Water-quality treatment statistics } & \multirow[b]{2}{*}{$\begin{array}{l}\text { MIC, } \\
\text { in ntu }\end{array}$} \\
\hline & & & & & & Minimum & LBMPV & UBMPV & Maximum & $\begin{array}{l}\text { Squared } \\
\text { residual }\end{array}$ & $\begin{array}{l}\text { Spearman's } \\
\text { Rho }\end{array}$ & \\
\hline \multicolumn{13}{|c|}{ NC SELDM study sites (paired highway-runoff and BMP sampling locations) } \\
\hline 20 & 175 & $\begin{array}{l}\text { NC I-77 Charlotte control (HMA) edge of pavement (Wu } \\
\text { and Allan, 2013) }\end{array}$ & $\begin{array}{l}\text { Filter } \\
\text { strip }\end{array}$ & 14 & 7.1 & 0.127 & 0.127 & 0.728 & 1.246 & 0.050 & -0.466 & 2.239 \\
\hline 21 & 179 & $\begin{array}{l}\text { NC SR } 1943 \text { Jordan Lake South swale influent } \\
\text { (Wu and Allan, 2014) }\end{array}$ & Swale & 21 & 57.1 & 0.076 & 0.076 & 1.052 & 2.681 & 0.101 & -0.740 & 1.450 \\
\hline \multicolumn{13}{|c|}{ Individual NC sites used in the national BMP study (Granato, 2014) } \\
\hline \multicolumn{13}{|c|}{$\begin{array}{l}\text { No NC sites used in national BMP study for this water-quality con- } \\
\text { stituent and BMP type. }\end{array}$} \\
\hline \multicolumn{13}{|c|}{ Median statistics } \\
\hline & & $\begin{array}{l}\text { NC SELDM plus NC national BMP study sites (listed } \\
\text { above) }, \mathrm{n}=2 \text { sites }\end{array}$ & & & & 0.102 & 0.102 & 0.890 & 1.964 & 0.075 & -0.603 & 1.844 \\
\hline & & National study sites (table 2 in Granato [2014]), $\mathrm{n}=1$ site & & & & 0.096 & 0.473 & 0.473 & 1.786 & 0.105 & -0.952 & 2.510 \\
\hline & & Lower $95 \%$ confidence interval (national s & tudy sites) & & & $\mathrm{n} / \mathrm{d}$ & $\mathrm{n} / \mathrm{d}$ & $\mathrm{n} / \mathrm{d}$ & $\mathrm{n} / \mathrm{d}$ & & & \\
\hline & & Upper $95 \%$ confidence interval (national s & tudy sites) & & & $\mathrm{n} / \mathrm{d}$ & $\mathrm{n} / \mathrm{d}$ & $\mathrm{n} / \mathrm{d}$ & $\mathrm{n} / \mathrm{d}$ & & & \\
\hline
\end{tabular}

${ }^{1}$ The HRDB QW highway dataset number is the "QWHighwayDataSet_ID" field in the HRDB that references the indicated highway-runoff research report. 
Table 13. Summary of total suspended solids water-quality treatment statistics for the trapezoidal distribution for best management practice (BMP) sites from North Carolina

Department of Transportation-partner highway-runoff studies.

[Efficiency ratio is outflow concentration divided by inflow concentration. Minimum irreducible concentrations (MICs) were computed by using the log-triangular lower-bound estimator method developed by Scherer and others (2003), as described in Granato (2014). Red shading indicates the North Carolina (NC) Stochastic Empirical Loading and Dilution Model (SELDM) median statistics are outside the range of the 95-percent confidence interval for the corresponding median statistics for the national study sites (Granato, 2014) and are thereby considered statistically different. HRDB, Highway-Runoff Database; LBMPV, lower bound of the most probable value; UBMPV, upper bound of the most probable value; mg/L, milligram per liter; I, Interstate; SR, Secondary Road; HMA, hot-mix-asphalt; OGFC, open-graded friction course; CR, concentration reduction; GS, grass swale; WC, wetland channel; VFS, vegetative filter strip; n/a, not available]

\begin{tabular}{|c|c|c|c|c|c|c|c|c|c|c|c|c|}
\hline \multirow{2}{*}{$\begin{array}{c}\text { HRDB } \\
\text { highway } \\
\text { dataset } \\
\text { number }^{1}\end{array}$} & \multirow{2}{*}{$\begin{array}{l}\text { HRDB } \\
\text { site } \\
\text { number } \\
\text { (fig. 8) }\end{array}$} & \multirow[b]{2}{*}{ Site } & \multirow[b]{2}{*}{ BMP type } & \multirow{2}{*}{$\begin{array}{c}\text { Number of } \\
\text { efficiency } \\
\text { ratio } \\
\text { samples }\end{array}$} & \multirow{2}{*}{$\begin{array}{c}\text { Ratio } \\
\geq 1 \\
\text { (percent) }\end{array}$} & \multicolumn{6}{|c|}{ Water-quality treatment statistics } & \multirow{2}{*}{$\begin{array}{c}\text { MIC, } \\
\text { in } \\
\mathrm{mg} / \mathrm{L}\end{array}$} \\
\hline & & & & & & Minimum & LBMPV & UBMPV & Maximum & $\begin{array}{l}\text { Squared } \\
\text { residual }\end{array}$ & $\begin{array}{c}\text { Spearman's } \\
\text { Rho }\end{array}$ & \\
\hline \multicolumn{13}{|c|}{ NC SELDM study sites (paired highway-runoff and BMP sampling locations) } \\
\hline 18 & 168 & $\begin{array}{l}\text { NC I-540 Mango Creek bioretention inlet (Luell and } \\
\text { others, 2012) }\end{array}$ & Bioretention & 23 & 21.7 & 0.000 & 0.000 & 0.000 & 2.098 & 0.539 & -0.384 & 2.323 \\
\hline 18 & 168 & $\begin{array}{l}\text { NC I-540 Mango Creek bioretention inlet (Luell and } \\
\text { others, 2012) }\end{array}$ & Bioretention & 29 & 24.1 & 0.000 & 0.000 & 0.000 & 2.924 & 1.581 & -0.639 & 3.757 \\
\hline \multicolumn{13}{|c|}{ Individual NC sites used in the national BMP study (Granato, 2014) } \\
\hline \multicolumn{13}{|c|}{$\begin{array}{l}\text { No NC sites used in national BMP study for this water-quality constituent } \\
\text { and BMP type. }\end{array}$} \\
\hline \multicolumn{13}{|c|}{ Median statistics } \\
\hline & & $\begin{array}{l}\text { NC SELDM plus NC national BMP study sites (listed } \\
\text { above), } n=2 \text { sites }\end{array}$ & & & & 0.000 & 0.000 & 0.000 & 2.511 & 1.060 & -0.512 & 3.040 \\
\hline & & $\begin{array}{l}\text { National study sites (table } 2 \text { in Granato [2014]), } \\
\mathrm{n}=8 \text { sites }\end{array}$ & & & & 0.000 & 0.000 & 0.000 & 1.232 & 0.144 & -0.563 & 0.370 \\
\hline & & Lower $95 \%$ confidence interval (national study sites) & & & & 0.000 & 0.000 & 0.000 & 0.431 & & & 0.043 \\
\hline & & Upper 95\% confidence interval (national study sites) & & & & 0.000 & 0.000 & 0.927 & 1.730 & & & 1.880 \\
\hline \multicolumn{13}{|c|}{ Grass swale BMP } \\
\hline \multicolumn{13}{|c|}{ NC SELDM study sites (paired highway-runoff and BMP sampling locations) } \\
\hline 18 & 169 & $\begin{array}{l}\text { NC I-540 Mango Creek swale inlet (Luell and others, } \\
\text { 2012) }\end{array}$ & Swale & 29 & 21.7 & 0.150 & 0.150 & 0.223 & 1.646 & 0.133 & -0.280 & 2.393 \\
\hline 20 & 174 & $\begin{array}{l}\text { NC I-77 Charlotte OGFC edge of pavement } \\
\text { (Wu and Allan, 2013) }\end{array}$ & Filter strip & 17 & 24.1 & 0.100 & 0.100 & 0.194 & 1.955 & 0.087 & -0.100 & 1.486 \\
\hline 20 & 175 & $\begin{array}{l}\text { NC I-77 Charlotte control (HMA) edge of pavement } \\
\text { (Wu and Allan, 2013) }\end{array}$ & Filter strip & 14 & 21.7 & 0.077 & 0.098 & 0.343 & 0.601 & 0.004 & -0.181 & 1.585 \\
\hline 20 & 176 & $\begin{array}{l}\text { NC I-85 Lexington OGFC edge of pavement } \\
\text { (Wu and Allan, 2013) }\end{array}$ & Filter strip & 11 & 24.1 & 0.148 & 0.148 & 0.378 & 1.219 & 0.057 & -0.747 & 4.401 \\
\hline 20 & 177 & $\begin{array}{l}\text { NC I-85 Lexington control (HMA) edge of pavement } \\
\text { (Wu and Allan, 2013) }\end{array}$ & Filter strip & 15 & 21.7 & 0.154 & 0.154 & 1.136 & 2.318 & 0.043 & -0.519 & 2.275 \\
\hline 16 & 152 & NC US 70 Business swale influent (Line, 2006) & Swale & 14 & 24.1 & 0.047 & 0.047 & 0.204 & 0.555 & 0.015 & -0.456 & 0.819 \\
\hline 21 & 179 & $\begin{array}{l}\text { NC SR } 1943 \text { Jordan Lake South swale influent } \\
\text { (Wu and Allan, 2014) }\end{array}$ & Swale & 22 & 21.7 & 0.000 & 0.000 & 0.000 & 1.623 & 0.158 & -0.365 & 0.615 \\
\hline 21 & 180 & $\begin{array}{l}\text { NC SR } 1360 \text { Mountain Island Lake swale influent } \\
\text { (Wu and Allan, 2014) }\end{array}$ & Swale & 23 & 24.1 & 0.112 & 0.112 & 0.236 & 1.596 & 0.070 & -0.297 & 2.235 \\
\hline
\end{tabular}


Table 13. Summary of total suspended solids water-quality treatment statistics for the trapezoidal distribution for best management practice (BMP) sites from North Carolina Department of Transportation-partner highway-runoff studies.-Continued

[Efficiency ratio is outflow concentration divided by inflow concentration. Minimum irreducible concentrations (MICs) were computed by using the log-triangular lower-bound estimator method developed by Scherer and others (2003), as described in Granato (2014). Red shading indicates the North Carolina (NC) Stochastic Empirical Loading and Dilution Model (SELDM) median statistics are outside the range of the 95-percent confidence interval for the corresponding median statistics for the national study sites (Granato, 2014) and are thereby considered statistically different. HRDB, Highway-Runoff Database; LBMPV, lower bound of the most probable value; UBMPV, upper bound of the most probable value; mg/L, milligram per liter; I, Interstate; SR, Secondary Road; HMA, hot-mix-asphalt; OGFC, open-graded friction course; CR, concentration reduction; GS, grass swale; WC, wetland channel; VFS, vegetative filter strip; n/a, not available]

\begin{tabular}{|c|c|c|c|c|c|c|c|c|c|c|c|c|}
\hline \multirow{2}{*}{$\begin{array}{c}\text { HRDB } \\
\text { highway } \\
\text { dataset } \\
\text { number }\end{array}$} & \multirow{2}{*}{$\begin{array}{l}\text { HRDB } \\
\text { site } \\
\text { number } \\
\text { (fig. 8) }\end{array}$} & \multirow[b]{2}{*}{ Site } & \multirow[b]{2}{*}{ BMP type } & \multirow{2}{*}{$\begin{array}{l}\text { Number of } \\
\text { efficiency } \\
\text { ratio } \\
\text { samples }\end{array}$} & \multirow{2}{*}{$\begin{array}{c}\text { Ratio } \\
\geq 1 \\
\text { (percent) }\end{array}$} & \multicolumn{6}{|c|}{ Water-quality treatment statistics } & \multirow{2}{*}{$\begin{array}{c}\text { MIC, } \\
\text { in } \\
\mathrm{mg} / \mathrm{L}\end{array}$} \\
\hline & & & & & & Minimum & LBMPV & UBMPV & Maximum & $\begin{array}{l}\text { Squared } \\
\text { residual }\end{array}$ & $\begin{array}{l}\text { Spearman's } \\
\text { Rho }\end{array}$ & \\
\hline $\mathrm{n} / \mathrm{a}$ & $\mathrm{n} / \mathrm{a}$ & CR-GS-p00530-118-NCDOT_VFS_A-2013-6-24.txt & GS - Biofilter & 13 & $\mathrm{n} / \mathrm{a}$ & 0.024 & 0.024 & 1.502 & 6.090 & 0.451 & -0.150 & 1.110 \\
\hline $\mathrm{n} / \mathrm{a}$ & $\mathrm{n} / \mathrm{a}$ & CR-GS-p00530-122-NCDOT_Swale_A-2013-6-24.txt & GS - Biofilter & 23 & $\mathrm{n} / \mathrm{a}$ & 0.111 & 1.663 & 1.663 & 3.518 & 0.073 & -0.374 & 3.190 \\
\hline $\mathrm{n} / \mathrm{a}$ & $\mathrm{n} / \mathrm{a}$ & CR-GS-p00530-123-NCDOT_VFS_D-2013-6-24.txt & GS - Biofilter & 15 & $\mathrm{n} / \mathrm{a}$ & 0.000 & 0.000 & 0.000 & 8.781 & 0.550 & -0.305 & 7.830 \\
\hline $\mathrm{n} / \mathrm{a}$ & $\mathrm{n} / \mathrm{a}$ & CR-GS-p00530-91-NCDOT_Swale_D-2013-6-24.txt & GS - Biofilter & 18 & $\mathrm{n} / \mathrm{a}$ & 0.000 & 6.166 & 6.166 & 10.030 & 3.167 & -0.283 & 1.160 \\
\hline \multicolumn{13}{|c|}{ Median statistics } \\
\hline & & $\begin{array}{l}\text { NC SELDM plus NC national BMP study sites (listed } \\
\text { above), } \mathrm{n}=12 \text { sites }\end{array}$ & & & & 0.089 & 0.106 & 0.289 & 1.800 & 0.080 & -0.301 & 1.910 \\
\hline & & $\begin{array}{l}\text { National study sites (table } 2 \text { in Granato [2014]), } \\
\mathrm{n}=17 \text { sites }\end{array}$ & & & & 0.000 & 0.024 & 0.205 & 1.966 & 0.190 & -0.500 & 3.195 \\
\hline & & Lower $95 \%$ confidence interval (national study sites) & & & & 0.000 & 0.000 & 0.000 & 1.593 & & & 1.870 \\
\hline & & Upper $95 \%$ confidence interval (national study sites) & & & & 0.111 & 0.216 & 0.996 & 3.518 & & & 6.960 \\
\hline \multicolumn{13}{|c|}{ Wetland channel (swale) BMP } \\
\hline
\end{tabular}

NC SELDM study sites (paired highway-runoff and BMP sampling locations)

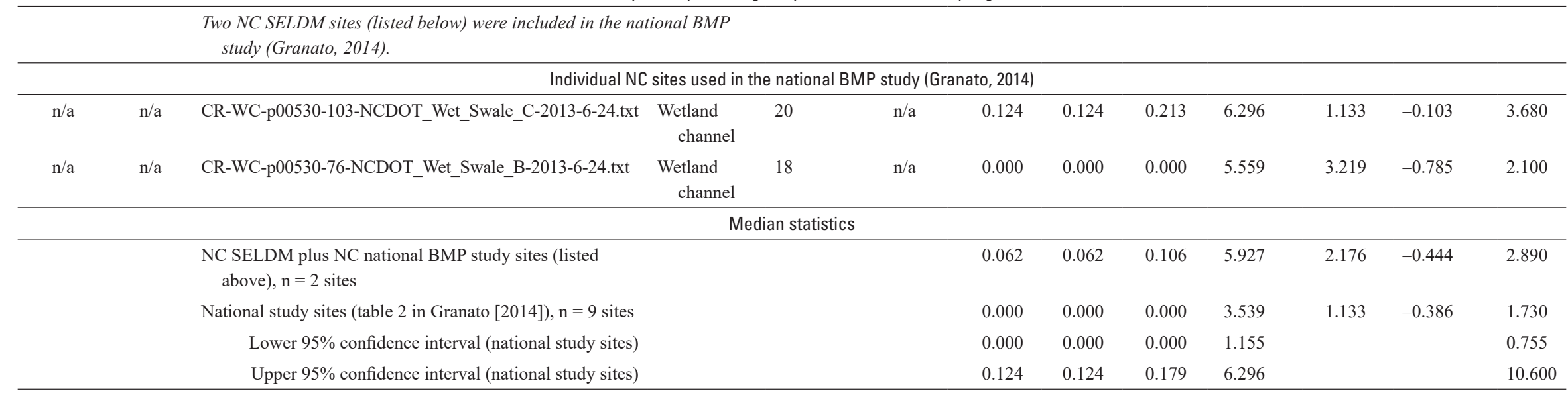

${ }^{1}$ The HRDB QW highway dataset number is the "QWHighwayDataSet_ID" field in the HRDB that references the indicated highway-runoff research report. 
Table 14. Summary of total nitrogen water-quality treatment statistics for the trapezoidal distribution for best management practice (BMP) sites from North Carolina

Department of Transportation-partner highway-runoff studies.

[Efficiency ratio is outflow concentration divided by inflow concentration. Minimum irreducible concentrations (MICs) were computed by using the log-triangular lower-bound estimator method developed by Scherer and others (2003), as described in Granato (2014). HRDB, Highway-Runoff Database; LBMPV, lower bound of the most probable value; UBMPV, upper bound of the most probable value; mg/L, milligram per liter; NC, North Carolina; SELDM, Stochastic Empirical Loading and Dilution Model; I, Interstate; SR, Secondary Road; HMA, hot-mix-asphalt; OGFC, open-graded friction course; CR, concentration reduction; GS, grass swale; WC, wetland channel; VFS, vegetative filter strip; n/a, not available; n/d, confidence interval not determined because sample size was less than eight (Granato, 2014)]

\begin{tabular}{|c|c|c|c|c|c|c|c|c|c|c|c|c|}
\hline \multirow{2}{*}{$\begin{array}{c}\text { HRDB } \\
\text { highway } \\
\text { dataset } \\
\text { number }^{1}\end{array}$} & \multirow{2}{*}{$\begin{array}{l}\text { HRDB } \\
\text { site } \\
\text { number } \\
\text { (fig. 8) }\end{array}$} & \multirow[b]{2}{*}{ Site } & \multirow[b]{2}{*}{ BMP type } & \multirow{2}{*}{$\begin{array}{c}\text { Number of } \\
\text { efficiency } \\
\text { ratio } \\
\text { samples }\end{array}$} & \multirow{2}{*}{$\begin{array}{c}\text { Ratio } \\
\geq 1 \\
\text { (percent) }\end{array}$} & \multicolumn{6}{|c|}{ Water-quality treatment statistics } & \multirow{2}{*}{$\begin{array}{c}\text { MIC, } \\
\text { in } \\
\mathrm{mg} / \mathrm{L}\end{array}$} \\
\hline & & & & & & Minimum & LBMPV & UBMPV & Maximum & $\begin{array}{l}\text { Squared } \\
\text { residual }\end{array}$ & $\begin{array}{l}\text { Spearman's } \\
\text { Rho }\end{array}$ & \\
\hline \multicolumn{13}{|c|}{ Bioretention BMP } \\
\hline \multicolumn{13}{|c|}{ NC SELDM study sites (paired highway-runoff and BMP sampling locations) } \\
\hline 18 & 168 & $\begin{array}{l}\text { NC I-540 Mango Creek bioretention inlet } \\
\text { (Luell and others, 2012) }\end{array}$ & Bioretention & 24 & 8.3 & 0.101 & 0.127 & 0.127 & 1.490 & 0.330 & -0.553 & 0.125 \\
\hline 18 & 168 & $\begin{array}{l}\text { NC I-540 Mango Creek bioretention inlet } \\
\text { (Luell and others, 2012) }\end{array}$ & Bioretention & 29 & 31.0 & 0.079 & 0.579 & 0.756 & 1.519 & 0.037 & -0.706 & 0.214 \\
\hline \multicolumn{13}{|c|}{ Individual NC sites used in the national BMP study (Granato, 2014) } \\
\hline \multicolumn{13}{|c|}{ No NC sites used in national BMP study for this water-quality constituent and BMP type. } \\
\hline \multicolumn{13}{|c|}{ Median statistics } \\
\hline & & $\begin{array}{l}\text { NC SELDM plus NC national BMP study sites (listed } \\
\text { above), } \mathrm{n}=2 \text { sites }\end{array}$ & & & & 0.090 & 0.353 & 0.442 & 1.505 & 0.184 & -0.629 & 0.170 \\
\hline & & $\begin{array}{l}\text { National study sites (table } 2 \text { in Granato [2014]), } \\
\mathrm{n}=8 \text { sites }\end{array}$ & & & & 0.148 & 0.400 & 0.593 & 2.010 & 0.144 & -0.636 & 0.365 \\
\hline & & Lower $95 \%$ confidence interval (national study sites) & & & & 0.008 & 0.200 & 0.200 & 1.324 & & & 0.131 \\
\hline & & Upper 95\% confidence interval (national study sites) & & & & 0.937 & 4.327 & 4.327 & 8.266 & & & 2.370 \\
\hline \multicolumn{13}{|c|}{ Grass swale BMP } \\
\hline \multicolumn{13}{|c|}{ NC SELDM study sites (paired highway-runoff and BMP sampling locations) } \\
\hline 18 & 169 & NC I-540 Mango Creek swale inlet (Luell and others, 2012) & Swale & 30 & 43.3 & 0.705 & 0.705 & 0.858 & 1.552 & 0.128 & -0.520 & 0.275 \\
\hline 20 & 174 & $\begin{array}{l}\text { NC I-77 Charlotte OGFC edge of pavement } \\
\text { (Wu and Allan, 2013) }\end{array}$ & Filter strip & 18 & 22.2 & 0.179 & 0.231 & 0.238 & 2.178 & 0.825 & 0.053 & 0.285 \\
\hline 20 & 175 & $\begin{array}{l}\text { NC I-77 Charlotte control (HMA) edge of pavement } \\
\text { (Wu and Allan, 2013) }\end{array}$ & Filter strip & 13 & 0.0 & 0.326 & 0.782 & 0.782 & 0.891 & 0.006 & -0.721 & 0.301 \\
\hline 20 & 176 & $\begin{array}{l}\text { NC I-85 Lexington OGFC edge of pavement } \\
\text { (Wu and Allan, 2013) }\end{array}$ & Filter strip & 13 & 53.8 & 0.406 & 0.406 & 0.455 & 2.572 & 0.148 & -0.372 & 0.222 \\
\hline 20 & 177 & $\begin{array}{l}\text { NC I-85 Lexington control (HMA) edge of pavement } \\
\text { (Wu and Allan, 2013) }\end{array}$ & Filter strip & 15 & 66.7 & 0.260 & 1.393 & 1.393 & 1.443 & 0.042 & -0.495 & 0.202 \\
\hline 16 & 152 & NC US 70 Business swale influent (Line, 2006) & Swale & 14 & 28.6 & 0.258 & 0.583 & 0.583 & 1.654 & 0.053 & -0.213 & 0.175 \\
\hline 21 & 178 & $\begin{array}{l}\text { NC SR } 1717 \text { Jordan Lake North swale influent } \\
\text { (Wu and Allan, 2014) }\end{array}$ & Swale & 18 & 11.1 & 0.165 & 0.165 & 0.483 & 1.594 & 0.226 & -0.875 & 0.094 \\
\hline 21 & 179 & $\begin{array}{l}\text { NC SR } 1943 \text { Jordan Lake South swale influent } \\
\text { (Wu and Allan, 2014) }\end{array}$ & Swale & 24 & 33.3 & 0.303 & 0.303 & 0.453 & 1.933 & 0.079 & -0.859 & 0.175 \\
\hline 21 & 180 & $\begin{array}{l}\text { NC SR } 1360 \text { Mountain Island Lake swale influent } \\
\text { (Wu and Allan, 2014) }\end{array}$ & Swale & 20 & 45.0 & 0.470 & 0.470 & 0.727 & 2.150 & 0.049 & -0.315 & 0.174 \\
\hline
\end{tabular}


Table 14. Summary of total nitrogen water-quality treatment statistics for the trapezoidal distribution for best management practice (BMP) sites from North Carolina Department of Transportation-partner highway-runoff studies.-Continued

[Efficiency ratio is outflow concentration divided by inflow concentration. Minimum irreducible concentrations (MICs) were computed by using the log-triangular lower-bound estimator method developed by Scherer and others (2003), as described in Granato (2014). HRDB, Highway-Runoff Database; LBMPV, lower bound of the most probable value; UBMPV, upper bound of the most probable value; mg/L, milligram per liter; NC, North Carolina; SELDM, Stochastic Empirical Loading and Dilution Model; I, Interstate; SR, Secondary Road; HMA, hot-mix-asphalt; OGFC, open-graded friction course;

CR, concentration reduction; GS, grass swale; WC, wetland channel; VFS, vegetative filter strip; n/a, not available; n/d, confidence interval not determined because sample size was less than eight (Granato, 2014)]

\begin{tabular}{|c|c|c|c|c|c|c|c|c|c|c|c|c|}
\hline \multirow{2}{*}{$\begin{array}{c}\text { HRDB } \\
\text { highway } \\
\text { dataset } \\
\text { number }\end{array}$} & \multirow{2}{*}{$\begin{array}{l}\text { HRDB } \\
\text { site } \\
\text { number } \\
\text { (fig. 8) }\end{array}$} & \multirow[b]{2}{*}{ Site } & \multirow[b]{2}{*}{ BMP type } & \multirow{2}{*}{$\begin{array}{c}\text { Number of } \\
\text { efficiency } \\
\text { ratio } \\
\text { samples }\end{array}$} & \multirow{2}{*}{$\begin{array}{c}\text { Ratio } \\
\geq 1 \\
\text { (percent) }\end{array}$} & \multicolumn{6}{|c|}{ Water-quality treatment statistics } & \multirow{2}{*}{$\begin{array}{c}\text { MIC, } \\
\text { in } \\
\mathrm{mg} / \mathrm{L}\end{array}$} \\
\hline & & & & & & Minimum & LBMPV & UBMPV & Maximum & $\begin{array}{l}\text { Squared } \\
\text { residual }\end{array}$ & $\begin{array}{c}\text { Spearman's } \\
\text { Rho }\end{array}$ & \\
\hline \multicolumn{13}{|c|}{ Individual NC sites used in the national BMP study (Granato, 2014) } \\
\hline $\mathrm{n} / \mathrm{a}$ & $\mathrm{n} / \mathrm{a}$ & CR-GS-p00600-118-NCDOT_VFS_A-2013-6-24.txt & GS - Biofilter & 13 & $\mathrm{n} / \mathrm{a}$ & 0.112 & 1.128 & 1.128 & 3.247 & 0.247 & -0.308 & 0.432 \\
\hline $\mathrm{n} / \mathrm{a}$ & $\mathrm{n} / \mathrm{a}$ & CR-GS-p00600-122-NCDOT_Swale_A-2013-6-24.txt & GS - Biofilter & 23 & $\mathrm{n} / \mathrm{a}$ & 0.316 & 1.210 & 1.210 & 2.308 & 0.079 & -0.611 & 0.620 \\
\hline $\mathrm{n} / \mathrm{a}$ & $\mathrm{n} / \mathrm{a}$ & CR-GS-p00600-123-NCDOT_VFS_D-2013-6-24.txt & GS - Biofilter & 15 & $\mathrm{n} / \mathrm{a}$ & 0.000 & 0.649 & 0.649 & 2.570 & 0.100 & -0.604 & 0.277 \\
\hline $\mathrm{n} / \mathrm{a}$ & $\mathrm{n} / \mathrm{a}$ & CR-GS-p00600-91-NCDOT_Swale_D-2013-6-24.txt & GS - Biofilter & 18 & $\mathrm{n} / \mathrm{a}$ & 0.078 & 0.098 & 0.124 & 2.273 & 0.198 & -0.697 & 0.569 \\
\hline \multicolumn{13}{|c|}{ Median statistics } \\
\hline & & $\begin{array}{l}\text { NC SELDM plus NC national BMP study sites (listed } \\
\text { above), } \mathrm{n}=13 \text { sites }\end{array}$ & & & & 0.260 & 0.583 & 0.649 & 2.150 & 0.100 & -0.520 & 0.275 \\
\hline & & National study sites (table 2 in Granato [2014]), $\mathrm{n}=9$ sites & & & & 0.174 & 0.642 & 0.642 & 2.270 & 0.198 & -0.552 & 0.425 \\
\hline & & Lower $95 \%$ confidence interval (national study sites) & & & & 0.078 & 0.174 & 0.178 & 2.008 & & & 0.212 \\
\hline & & Upper $95 \%$ confidence interval (national study sites) & & & & 0.421 & 1.210 & 1.210 & 3.247 & & & 0.878 \\
\hline
\end{tabular}

NC SELDM study sites (paired highway-runoff and BMP sampling locations)

\begin{tabular}{|c|c|c|c|c|c|c|c|c|c|c|c|c|}
\hline \multicolumn{13}{|c|}{$\begin{array}{l}\text { Two NC SELDM sites (listed below) were included in the national BMP } \\
\text { study (Granato, 2014). }\end{array}$} \\
\hline \multicolumn{13}{|c|}{ Individual NC sites used in the national BMP study (Granato, 2014) } \\
\hline $\mathrm{n} / \mathrm{a}$ & $\mathrm{n} / \mathrm{a}$ & CR-WC-p00600-103-NCDOT_Wet_Swale_C-2013-6-24.txt & $\begin{array}{l}\text { Wetland } \\
\text { channel }\end{array}$ & 20 & $\mathrm{n} / \mathrm{a}$ & 0.190 & 0.233 & 0.474 & 1.596 & 0.130 & -0.473 & 0.383 \\
\hline $\mathrm{n} / \mathrm{a}$ & $\mathrm{n} / \mathrm{a}$ & CR-WC-p00600-76-NCDOT_Wet_Swale_B-2013-6-24.txt & $\begin{array}{l}\text { Wetland } \\
\text { channel }\end{array}$ & 18 & $\mathrm{n} / \mathrm{a}$ & 0.185 & 0.185 & 1.597 & 1.814 & 0.042 & -0.717 & 0.396 \\
\hline \multicolumn{13}{|c|}{ Median statistics } \\
\hline & & $\begin{array}{l}\text { NC SELDM plus NC national BMP study sites (listed } \\
\text { above), } \mathrm{n}=2 \text { sites }\end{array}$ & & & & 0.187 & 0.209 & 1.035 & 1.705 & 0.086 & -0.595 & 0.390 \\
\hline & & National study sites (table 2 in Granato [2014]), $\mathrm{n}=6$ sites & & & & 0.346 & 0.367 & 0.539 & 1.705 & 0.067 & -0.595 & 0.396 \\
\hline & & Lower $95 \%$ confidence interval (national study sites) & & & & $\mathrm{n} / \mathrm{d}$ & $\mathrm{n} / \mathrm{d}$ & $\mathrm{n} / \mathrm{d}$ & $\mathrm{n} / \mathrm{d}$ & & & $\mathrm{n} / \mathrm{d}$ \\
\hline & & Upper $95 \%$ confidence interval (national study sites) & & & & $\mathrm{n} / \mathrm{d}$ & $\mathrm{n} / \mathrm{d}$ & $\mathrm{n} / \mathrm{d}$ & $\mathrm{n} / \mathrm{d}$ & & & $\mathrm{n} / \mathrm{d}$ \\
\hline
\end{tabular}

${ }^{1}$ The HRDB QW highway dataset number is the "QWHighwayDataSet_ID" field in the HRDB that references the indicated highway-runoff research report. 
Table 15. Summary of total phosphorus water-quality treatment statistics for the trapezoidal distribution for best management practice (BMP) sites from North Carolina Department of Transportation-partner highway-runoff studies.

[Efficiency ratio is outflow concentration divided by inflow concentration. Minimum irreducible concentrations (MICs) were computed by using the log-triangular lower-bound estimator method developed by Scherer and others (2003), as described in Granato (2014). HRDB, Highway-Runoff Database; LBMPV, lower bound of the most probable value; UBMPV, upper bound of the most probable value; mg/L, milligram per liter; NC, North Carolina; SELDM, Stochastic Empirical Loading and Dilution Model; I, Interstate; SR, Secondary Road; HMA, hot-mix-asphalt; OGFC, open-graded friction course; CR, concentration reduction; GS, grass swale; WC, wetland channel; VFS, vegetative filter strip; n/a, not available]

\begin{tabular}{|c|c|c|c|c|c|c|c|c|c|c|c|c|}
\hline \multirow{2}{*}{$\begin{array}{c}\text { HRDB } \\
\text { highway } \\
\text { dataset } \\
\text { number }\end{array}$} & \multirow{2}{*}{$\begin{array}{l}\text { HRDB } \\
\text { site } \\
\text { number } \\
\text { (fig. 8) }\end{array}$} & \multirow[b]{2}{*}{ Site } & \multirow[b]{2}{*}{ BMP type } & \multirow{2}{*}{$\begin{array}{c}\text { Number of } \\
\text { efficiency } \\
\text { ratio } \\
\text { samples }\end{array}$} & \multirow{2}{*}{$\begin{array}{c}\text { Ratio } \\
\geq 1 \\
\text { (percent) }\end{array}$} & \multicolumn{6}{|c|}{ Water-quality treatment statistics } & \multirow{2}{*}{$\begin{array}{c}\text { MIC, } \\
\text { in } \\
\mathrm{mg} / \mathrm{L}\end{array}$} \\
\hline & & & & & & Minimum & LBMPV & UBMPV & Maximum & $\begin{array}{l}\text { Squared } \\
\text { residual }\end{array}$ & $\begin{array}{l}\text { Spearman's } \\
\text { Rho }\end{array}$ & \\
\hline \multicolumn{13}{|c|}{ Bioretention BMP } \\
\hline \multicolumn{13}{|c|}{ NC SELDM study sites (paired highway-runoff and BMP sampling locations) } \\
\hline 18 & 168 & $\begin{array}{l}\text { NC I-540 Mango Creek bioretention inlet (Luell and others, } \\
\text { 2012) }\end{array}$ & Bioretention & 24 & 58.3 & 0.000 & 0.000 & 0.000 & 4.744 & 1.682 & -0.764 & 0.027 \\
\hline 18 & 168 & $\begin{array}{l}\text { NC I-540 Mango Creek bioretention inlet (Luell and others, } \\
\text { 2012) }\end{array}$ & Bioretention & 29 & 69.0 & 0.087 & 0.087 & 0.134 & 4.637 & 1.321 & -0.667 & 0.033 \\
\hline \multicolumn{13}{|c|}{ Individual NC sites used in the national BMP study (Granato, 2014) } \\
\hline \multicolumn{13}{|c|}{$\begin{array}{l}\text { No NC sites used in national BMP study for this water-quality constituent } \\
\text { and BMP type. }\end{array}$} \\
\hline \multicolumn{13}{|c|}{ Median statistics } \\
\hline & & $\begin{array}{l}\text { NC SELDM plus NC national BMP study sites (listed } \\
\text { above), } \mathrm{n}=2 \text { sites }\end{array}$ & & & & 0.044 & 0.044 & 0.067 & 4.691 & 1.501 & -0.715 & 0.030 \\
\hline & & National study sites (table 2 in Granato [2014]), $\mathrm{n}=14$ sites & & & & 0.013 & 0.176 & 0.325 & 2.339 & 0.210 & -0.420 & 0.029 \\
\hline & & Lower 95\% confidence interval (national study sites) & & & & 0.000 & 0.010 & 0.040 & 1.925 & & & 0.022 \\
\hline & & Upper $95 \%$ confidence interval (national study sites) & & & & 0.314 & 0.864 & 0.926 & 5.799 & & & 0.086 \\
\hline \multicolumn{13}{|c|}{ Grass swale BMP } \\
\hline \multicolumn{13}{|c|}{ NC SELDM study sites (paired highway-runoff and BMP sampling locations) } \\
\hline 18 & 169 & NC I-540 Mango Creek swale inlet (Luell and others, 2012) & Swale & 31 & 61.3 & 0.401 & 0.401 & 1.088 & 2.421 & 0.343 & -0.567 & 0.023 \\
\hline 20 & 175 & $\begin{array}{l}\text { NC I-77 Charlotte control (HMA) edge of pavement } \\
\text { (Wu and Allan, 2013) }\end{array}$ & Filter strip & 15 & 46.7 & 0.000 & 0.717 & 0.717 & 2.206 & 0.101 & -0.868 & 0.078 \\
\hline 20 & 176 & $\begin{array}{l}\text { NC I-85 Lexington OGFC edge of pavement (Wu and } \\
\text { Allan, 2013) }\end{array}$ & Filter strip & 13 & 69.2 & 0.303 & 0.303 & 0.824 & 3.291 & 0.264 & -0.899 & 0.071 \\
\hline 21 & 179 & $\begin{array}{l}\text { NC SR } 1943 \text { Jordan Lake South swale influent (Wu and } \\
\text { Allan, 2014) }\end{array}$ & Swale & 21 & 47.6 & 0.519 & 0.519 & 0.519 & 1.868 & 0.015 & -0.749 & 0.024 \\
\hline 21 & 180 & $\begin{array}{l}\text { NC SR } 1360 \text { Mountain Island Lake swale influent } \\
\text { (Wu and Allan, 2014) }\end{array}$ & Swale & 23 & 60.9 & 0.283 & 0.965 & 0.965 & 2.159 & 0.075 & -0.514 & 0.047 \\
\hline \multicolumn{13}{|c|}{ Individual NC sites used in the national BMP study (Granato, 2014) } \\
\hline $\mathrm{n} / \mathrm{a}$ & $\mathrm{n} / \mathrm{a}$ & CR-GS-p00665-118-NCDOT_VFS_A-2013-6-23.txt & GS - Biofilter & 13 & $\mathrm{n} / \mathrm{a}$ & 0.000 & 0.000 & 0.000 & 19.611 & 4.597 & -0.829 & 0.057 \\
\hline $\mathrm{n} / \mathrm{a}$ & $\mathrm{n} / \mathrm{a}$ & CR-GS-p00665-122-NCDOT_Swale_A-2013-6-23.txt & GS - Biofilter & 23 & $\mathrm{n} / \mathrm{a}$ & 0.130 & 0.130 & 3.027 & 4.214 & 0.175 & -0.840 & 0.105 \\
\hline $\mathrm{n} / \mathrm{a}$ & $\mathrm{n} / \mathrm{a}$ & CR-GS-p00665-123-NCDOT_VFS_D-2013-6-23.txt & GS - Biofilter & 15 & $\mathrm{n} / \mathrm{a}$ & 0.573 & 1.422 & 1.422 & 8.221 & 0.462 & -0.640 & 0.057 \\
\hline $\mathrm{n} / \mathrm{a}$ & $\mathrm{n} / \mathrm{a}$ & CR-GS-p00665-91-NCDOT_Swale_D-2013-6-23.txt & GS - Biofilter & 18 & $\mathrm{n} / \mathrm{a}$ & 0.390 & 0.390 & 0.421 & 4.881 & 8.229 & -0.398 & 0.031 \\
\hline
\end{tabular}


Table 15. Summary of total phosphorus water-quality treatment statistics for the trapezoidal distribution for best management practice (BMP) sites from North Carolina Department of Transportation-partner highway-runoff studies. - Continued

[Efficiency ratio is outflow concentration divided by inflow concentration. Minimum irreducible concentrations (MICs) were computed by using the log-triangular lower-bound estimator method developed by Scherer and others (2003), as described in Granato (2014). HRDB, Highway-Runoff Database; LBMPV, lower bound of the most probable value; UBMPV, upper bound of the most probable value; mg/L, milligram per liter; NC, North Carolina; SELDM, Stochastic Empirical Loading and Dilution Model; I, Interstate; SR, Secondary Road; HMA, hot-mix-asphalt; OGFC, open-graded friction course; CR, concentration reduction; GS, grass swale; WC, wetland channel; VFS, vegetative filter strip; n/a, not available]

\begin{tabular}{|c|c|c|c|c|c|c|c|c|c|c|c|c|}
\hline \multirow{2}{*}{$\begin{array}{c}\text { HRDB } \\
\text { highway } \\
\text { dataset } \\
\text { number }\end{array}$} & \multirow{2}{*}{$\begin{array}{l}\text { HRDB } \\
\text { site } \\
\text { number } \\
\text { (fig. 8) }\end{array}$} & \multirow[b]{2}{*}{ Site } & \multirow[b]{2}{*}{ BMP type } & \multirow{2}{*}{$\begin{array}{c}\text { Number of } \\
\text { efficiency } \\
\text { ratio } \\
\text { samples }\end{array}$} & \multirow{2}{*}{$\begin{array}{c}\text { Ratio } \\
\geq 1 \\
\text { (percent) }\end{array}$} & \multicolumn{6}{|c|}{ Water-quality treatment statistics } & \multirow{2}{*}{$\begin{array}{c}\text { MIC, } \\
\text { in } \\
\mathrm{mg} / \mathrm{L}\end{array}$} \\
\hline & & & & & & Minimum & LBMPV & UBMPV & Maximum & $\begin{array}{l}\text { Squared } \\
\text { residual }\end{array}$ & $\begin{array}{l}\text { Spearman's } \\
\text { Rho }\end{array}$ & \\
\hline \multicolumn{13}{|c|}{ Median statistics } \\
\hline & & $\begin{array}{l}\text { NC SELDM plus NC national BMP study sites (listed } \\
\text { above), } \mathrm{n}=9 \text { sites }\end{array}$ & & & & 0.303 & 0.401 & 0.824 & 3.291 & 0.264 & -0.749 & 0.057 \\
\hline & & National study sites (table 2 in Granato [2014]), $\mathrm{n}=17$ sites & & & & 0.105 & 0.669 & 0.827 & 3.556 & 0.177 & -0.669 & 0.066 \\
\hline & & Lower $95 \%$ confidence interval (national study sites) & & & & 0.001 & 0.305 & 0.364 & 2.792 & & & 0.042 \\
\hline & & Upper $95 \%$ confidence interval (national study sites) & & & & 0.390 & 1.106 & 2.202 & 4.881 & & & 0.114 \\
\hline \multicolumn{13}{|c|}{ Wetland channel (swale) BMP } \\
\hline \multicolumn{13}{|c|}{ NC SELDM study sites (paired highway-runoff and BMP sampling locations) } \\
\hline \multicolumn{13}{|c|}{$\begin{array}{l}\text { Two NC SELDM sites (listed below) were included in the national BMP } \\
\text { study (Granato, 2014). }\end{array}$} \\
\hline \multicolumn{13}{|c|}{ Individual NC sites used in the national BMP study (Granato, 2014) } \\
\hline $\mathrm{n} / \mathrm{a}$ & $\mathrm{n} / \mathrm{a}$ & $\begin{array}{l}\text { CR-WC-p00665-103-NCDOT_Wet_Swale_C-2013-6-23. } \\
\text { txt }\end{array}$ & $\begin{array}{l}\text { Wetland } \\
\text { channel }\end{array}$ & 20 & $\mathrm{n} / \mathrm{a}$ & 0.226 & 0.226 & 0.902 & 2.308 & 0.042 & -0.598 & 0.026 \\
\hline $\mathrm{n} / \mathrm{a}$ & $\mathrm{n} / \mathrm{a}$ & CR-WC-p00665-76-NCDOT_Wet_Swale_B-2013-6-23.txt & $\begin{array}{l}\text { Wetland } \\
\text { channel }\end{array}$ & 18 & $\mathrm{n} / \mathrm{a}$ & 0.000 & 0.000 & 0.000 & 5.634 & 0.223 & -0.866 & 0.038 \\
\hline \multicolumn{13}{|c|}{ Median statistics } \\
\hline & & $\begin{array}{l}\text { NC SELDM plus NC national BMP study sites (listed } \\
\text { above), } n=2 \text { sites }\end{array}$ & & & & 0.113 & 0.113 & 0.451 & 3.971 & 0.132 & -0.732 & 0.032 \\
\hline & & National study sites (table 2 in Granato [2014]), $\mathrm{n}=9$ sites & & & & 0.171 & 0.226 & 0.623 & 2.203 & 0.077 & -0.401 & 0.035 \\
\hline & & Lower $95 \%$ confidence interval (national study sites) & & & & 0.000 & 0.060 & 0.080 & 1.851 & & & 0.020 \\
\hline & & Upper $95 \%$ confidence interval (national study sites) & & & & 0.396 & 0.992 & 1.037 & 5.634 & & & 0.180 \\
\hline
\end{tabular}

${ }^{1}$ The HRDB QW highway dataset number is the "QWHighwayDataSet_ID" field in the HRDB that references the indicated highway-runoff research report. 
Table 16. Summary of nitrate plus nitrite $\left(\mathrm{NO}_{3}+\mathrm{NO}_{2}\right)$ water-quality treatment statistics for the trapezoidal distribution for best management practice (BMP) sites from North Carolina Department of Transportation-partner highway-runoff studies.

[Efficiency ratio is outflow concentration divided by inflow concentration. Minimum irreducible concentrations (MICs) were computed by using the log-triangular lower-bound estimator method developed by Scherer and others (2003), as described in Granato (2014). Red shading indicates the North Carolina (NC) Stochastic Empirical Loading and Dilution Model (SELDM) median statistics are outside the range of the 95-percent confidence interval for the corresponding median statistics for the national study sites (Granato, 2014) and are thereby considered statistically different. HRDB, Highway-Runoff Database; LBMPV, lower bound of the most probable value; UBMPV, upper bound of the most probable value; mg/L, milligram per liter; I, Interstate; SR, Secondary Road; Rd, Road; HMA, hot-mix-asphalt; OGFC, open-graded friction course; CR, concentration reduction; GS, grass swale; WC, wetland channel; VFS, vegetative filter strip; n/d, confidence interval not determined because sample size was less than eight (Granato, 2014)]

\begin{tabular}{|c|c|c|c|c|c|c|c|c|c|c|c|c|}
\hline \multirow{2}{*}{$\begin{array}{c}\text { HRDB } \\
\text { highway } \\
\text { dataset } \\
\text { number' }\end{array}$} & \multirow{2}{*}{$\begin{array}{l}\text { HRDB } \\
\text { site } \\
\text { number } \\
\text { (fig. 8) }\end{array}$} & \multirow[b]{2}{*}{ Site } & \multirow[b]{2}{*}{ BMP type } & \multirow{2}{*}{$\begin{array}{c}\text { Number of } \\
\text { efficiency } \\
\text { ratio } \\
\text { samples } \\
\end{array}$} & \multirow[b]{2}{*}{$\begin{array}{c}\text { Ratio } \\
\geq 1 \\
\text { (percent) }\end{array}$} & \multicolumn{6}{|c|}{ Water-quality treatment statistics } & \multirow[b]{2}{*}{$\begin{array}{c}\text { MIC, } \\
\text { in } \\
\mathrm{mg} / \mathrm{L}\end{array}$} \\
\hline & & & & & & Minimum & LBMPV & UBMPV & Maximum & $\begin{array}{l}\text { Squared } \\
\text { residual }\end{array}$ & $\begin{array}{l}\text { Spearman's } \\
\text { Rho }\end{array}$ & \\
\hline \multicolumn{13}{|c|}{ Bioretention BMP } \\
\hline \multicolumn{13}{|c|}{ NC SELDM study sites (paired highway-runoff and BMP sampling locations) } \\
\hline 18 & 168 & NC I-540 Mango Creek bioretention inlet (Luell and others, 2012) & Bioretention & 24 & 0.0 & 0.000 & 0.000 & 0.000 & 1.028 & 0.070 & -0.667 & 0.004 \\
\hline 18 & 168 & NC I-540 Mango Creek bioretention inlet (Luell and others, 2012) & Bioretention & 29 & 10.3 & 0.000 & 0.000 & 0.237 & 1.508 & 0.619 & -0.578 & 0.010 \\
\hline \multicolumn{13}{|c|}{ Individual NC sites used in the national BMP study (Granato, 2014) } \\
\hline \multicolumn{13}{|c|}{$\begin{array}{l}\text { No NC sites used in national BMP study for this water-quality constituent and } \\
\text { BMP type. }\end{array}$} \\
\hline \multicolumn{13}{|c|}{ Median statistics } \\
\hline & & $\begin{array}{l}\text { NC SELDM plus NC national BMP study sites (listed above), } \\
\mathrm{n}=2 \text { sites }\end{array}$ & & & & 0.000 & 0.000 & 0.119 & 1.268 & 0.344 & -0.622 & 0.007 \\
\hline & & National study sites (table 2 in Granato [2014]), $\mathrm{n}=3$ sites & & & & 0.000 & 0.286 & 0.939 & 1.769 & 0.177 & 0.002 & 0.006 \\
\hline & & Lower $95 \%$ confidence interval (national study sites) & & & & $\mathrm{n} / \mathrm{d}$ & $\mathrm{n} / \mathrm{d}$ & $\mathrm{n} / \mathrm{d}$ & $\mathrm{n} / \mathrm{d}$ & & & $\mathrm{n} / \mathrm{d}$ \\
\hline & & Upper $95 \%$ confidence interval (national study sites) & & & & $\mathrm{n} / \mathrm{d}$ & $\mathrm{n} / \mathrm{d}$ & $\mathrm{n} / \mathrm{d}$ & $\mathrm{n} / \mathrm{d}$ & & & $\mathrm{n} / \mathrm{d}$ \\
\hline \multicolumn{13}{|c|}{ Grass swale BMP } \\
\hline \multicolumn{13}{|c|}{ NC SELDM study sites (paired highway-runoff and BMP sampling locations) } \\
\hline 18 & 169 & NC I-540 Mango Creek swale inlet (Luell and others, 2012) & Swale & 31 & 54.8 & 0.597 & 0.597 & 0.612 & 2.138 & 1.185 & -0.547 & 0.062 \\
\hline 20 & 174 & NC I-77 Charlotte OGFC edge of pavement (Wu and Allan, 2013) & Filter strip & 19 & 15.8 & 0.109 & 0.109 & 0.256 & 1.828 & 0.383 & -0.691 & 0.022 \\
\hline 20 & 175 & $\begin{array}{l}\text { NC I-77 Charlotte control (HMA) edge of pavement } \\
\text { (Wu and Allan, 2013) }\end{array}$ & Filter strip & 15 & 20.0 & 0.108 & 0.108 & 0.465 & 1.916 & 0.379 & -0.102 & 0.004 \\
\hline 20 & 176 & NC I-85 Lexington OGFC edge of pavement (Wu and Allan, 2013) & Filter strip & 13 & 15.4 & 0.092 & 0.092 & 0.259 & 1.337 & 0.026 & -0.160 & 0.004 \\
\hline 20 & 177 & $\begin{array}{l}\text { NC I-85 Lexington control (HMA) edge of pavement } \\
\text { (Wu and Allan, 2013) }\end{array}$ & Filter strip & 16 & 31.3 & 0.130 & 0.529 & 0.529 & 2.019 & 0.211 & -0.253 & 0.007 \\
\hline 16 & 152 & NC US 70 Business swale influent (Line, 2006) & Swale & 14 & 35.7 & 0.005 & 0.005 & 0.065 & 2.794 & 0.348 & -0.277 & 0.019 \\
\hline 21 & 178 & $\begin{array}{l}\text { NC SR } 1717 \text { Jordan Lake North swale influent (Wu and Allan, } \\
\text { 2014) }\end{array}$ & Swale & 18 & 11.1 & 0.000 & 0.000 & 0.000 & 1.542 & 0.112 & -0.559 & 0.005 \\
\hline 21 & 179 & $\begin{array}{l}\text { NC SR } 1943 \text { Jordan Lake South swale influent (Wu and Allan, } \\
\text { 2014) }\end{array}$ & Swale & 24 & 4.2 & 0.000 & 0.000 & 0.000 & 0.904 & 0.124 & 0.168 & 0.003 \\
\hline 21 & 180 & $\begin{array}{l}\text { NC SR } 1360 \text { Mountain Island Lake swale influent } \\
\text { (Wu and Allan, 2014) }\end{array}$ & Swale & 23 & 17.4 & 0.000 & 0.000 & 0.000 & 1.588 & 0.474 & -0.245 & 0.004 \\
\hline 19 & 170 & $\begin{array}{l}\text { NC I-40 near Strickland Crossroads Rd swale influent (site A) } \\
\text { (Winston and others, 2012) }\end{array}$ & Swale & 19 & 21.1 & 0.000 & 0.000 & 0.753 & 1.508 & 0.062 & -0.011 & 0.014 \\
\hline 19 & 170 & NC I-40 near Strickland Crossroads Rd swale influent (site A) & Filter strip & 13 & 38.5 & 0.000 & 0.000 & 0.000 & 2.712 & 0.177 & -0.088 & 0.021 \\
\hline
\end{tabular}


Table 16. Summary of nitrate plus nitrite $\left(\mathrm{NO}_{3}+\mathrm{NO}_{2}\right)$ water-quality treatment statistics for the trapezoidal distribution for best management practice (BMP) sites from North Carolina Department of Transportation-partner highway-runoff studies.-Continued

[Efficiency ratio is outflow concentration divided by inflow concentration. Minimum irreducible concentrations (MICs) were computed by using the log-triangular lower-bound estimator method developed by Scherer and others (2003), as described in Granato (2014). Red shading indicates the North Carolina (NC) Stochastic Empirical Loading and Dilution Model (SELDM) median statistics are outside the range of the 95-percent confidence interval for the corresponding median statistics for the national study sites (Granato, 2014) and are thereby considered statistically different. HRDB, Highway-Runoff Database; LBMPV, lower bound of the most probable value; UBMPV, upper bound of the most probable value; mg/L, milligram per liter; I, Interstate; SR, Secondary Road; Rd, Road; HMA, hot-mix-asphalt; OGFC, open-graded friction course; CR, concentration reduction; GS, grass swale; WC, wetland channel; VFS, vegetative filter strip; n/d, confidence interval not determined because sample size was less than eight (Granato, 2014)]

\begin{tabular}{|c|c|c|c|c|c|c|c|c|c|c|c|c|}
\hline \multirow{2}{*}{$\begin{array}{c}\text { HRDB } \\
\text { highway } \\
\text { dataset } \\
\text { number }^{1}\end{array}$} & \multirow{2}{*}{$\begin{array}{c}\text { HRDB } \\
\text { site } \\
\text { number } \\
\text { (fig. 8) }\end{array}$} & \multirow[b]{2}{*}{ Site } & \multirow[b]{2}{*}{ BMP type } & \multirow{2}{*}{$\begin{array}{c}\text { Number of } \\
\text { efficiency } \\
\text { ratio } \\
\text { samples }\end{array}$} & \multirow{2}{*}{$\begin{array}{c}\text { Ratio } \\
\geq 1 \\
\text { (per- } \\
\text { cent) }\end{array}$} & \multicolumn{6}{|c|}{ Water-quality treatment statistics } & \multirow{2}{*}{$\begin{array}{c}\text { MIC, } \\
\text { in } \\
\mathrm{mg} / \mathrm{L}\end{array}$} \\
\hline & & & & & & Minimum & LBMPV & UBMPV & Maximum & $\begin{array}{l}\text { Squared } \\
\text { residual }\end{array}$ & $\begin{array}{l}\text { Spearman's } \\
\text { Rho }\end{array}$ & \\
\hline \multicolumn{13}{|c|}{ Grass swale BMP } \\
\hline \multicolumn{13}{|c|}{ NC SELDM study sites (paired highway-runoff and BMP sampling locations) } \\
\hline 19 & 173 & $\begin{array}{l}\text { NC I-40 near McGowen Rd swale influent (site D) (Winston and } \\
\text { others, 2012) }\end{array}$ & Swale & 16 & 0.0 & 0.003 & 0.003 & 0.182 & 0.416 & 0.002 & -0.012 & 0.011 \\
\hline 19 & 173 & $\begin{array}{l}\text { NC I-40 near McGowen Rd swale influent (site D) (Winston and } \\
\text { others, 2012) }\end{array}$ & Filter strip & 13 & 0.0 & 0.000 & 0.000 & 0.277 & 0.908 & 0.030 & -0.213 & 0.014 \\
\hline \multicolumn{13}{|c|}{ Individual NC sites used in the national BMP study (Granato, 2014) } \\
\hline \multicolumn{13}{|c|}{$\begin{array}{l}\text { No NC sites used in national BMP study for this water-quality constituent and } \\
\text { BMP type. }\end{array}$} \\
\hline \multicolumn{13}{|c|}{ Median statistics } \\
\hline & & $\begin{array}{l}\text { NC SELDM plus NC national BMP study sites (listed above), } \\
\mathrm{n}=13 \text { sites }\end{array}$ & & & & 0.003 & 0.003 & 0.256 & 1.588 & 0.177 & -0.213 & 0.011 \\
\hline & & National study sites (table 2 in Granato [2014]), $\mathrm{n}=8$ sites & & & & 0.145 & 0.687 & 0.814 & 2.264 & 0.086 & -0.265 & 0.024 \\
\hline & & Lower $95 \%$ confidence interval (national study sites) & & & & 0.050 & 0.483 & 0.631 & 1.684 & & & 0.011 \\
\hline & & Upper $95 \%$ confidence interval (national study sites) & & & & 0.641 & 1.518 & 1.523 & 5.063 & & & 0.180 \\
\hline \multicolumn{13}{|c|}{ Wetland channel (swale) BMP } \\
\hline \multicolumn{13}{|c|}{ NC SELDM study sites (paired highway-runoff and BMP sampling locations) } \\
\hline 19 & 171 & $\begin{array}{r}\text { NC I-40 near Five Points Rd swale influent (site B) (Winston and } \\
\text { others, 2012) }\end{array}$ & $\begin{array}{l}\text { Swale } \\
\text { (wetland) }\end{array}$ & 18 & 0.0 & 0.000 & 0.000 & 0.000 & 0.839 & 0.045 & -0.322 & 0.010 \\
\hline 19 & 172 & $\begin{array}{r}\text { NC I-40 near Giddensville Rd swale influent (site C) (Winston } \\
\text { and others, 2012) }\end{array}$ & $\begin{array}{l}\text { Swale } \\
\quad \text { (wetland) }\end{array}$ & 18 & 0.0 & 0.000 & 0.000 & 0.141 & 0.737 & 0.007 & -0.346 & 0.007 \\
\hline \multicolumn{13}{|c|}{ Individual NC sites used in the national BMP study (Granato, 2014) } \\
\hline \multicolumn{13}{|c|}{$\begin{array}{l}\text { No NC sites used in national BMP study for this water-quality constituent and } \\
\text { BMP type }\end{array}$} \\
\hline \multicolumn{13}{|c|}{ Median statistics } \\
\hline & & $\begin{array}{l}\text { NC SELDM plus NC national BMP study sites (listed above), } \\
\mathrm{n}=2 \text { sites }\end{array}$ & & & & 0.000 & 0.000 & 0.071 & 0.788 & 0.026 & -0.334 & 0.009 \\
\hline & & National study sites (table 2 in Granato [2014]), $\mathrm{n}=1$ site & & & & 0.199 & 0.199 & 0.213 & 1.316 & 0.203 & -0.111 & 0.573 \\
\hline & & Lower $95 \%$ confidence interval (national study sites) & & & & $\mathrm{n} / \mathrm{d}$ & $\mathrm{n} / \mathrm{d}$ & $\mathrm{n} / \mathrm{d}$ & $\mathrm{n} / \mathrm{d}$ & & & $\mathrm{n} / \mathrm{d}$ \\
\hline & & Upper $95 \%$ confidence interval (national study sites) & & & & $\mathrm{n} / \mathrm{d}$ & $\mathrm{n} / \mathrm{d}$ & $\mathrm{n} / \mathrm{d}$ & $\mathrm{n} / \mathrm{d}$ & & & $\mathrm{n} / \mathrm{d}$ \\
\hline
\end{tabular}

${ }^{1}$ The HRDB QW highway dataset number is the "QWHighwayDataSet_ID" field in the HRDB that references the indicated highway-runoff research report. 
because more than 70 percent of the efficiency ratios were greater than or equal to $1(71,72,79,86,92$, and 100 percent). No additional sites were available from the International Stormwater BMP Database. Therefore, a total of two sites were used in computing the North Carolina SELDM medians for the minimum, LBMPV, UBMPV, and maximum turbidity statistics (table 12). Because only one grass swale BMP study site was included in the national BMP study, no confidence intervals were determined for the medians in the national BMP study (Granato, 2014).

\section{Total Suspended Solids}

For the BMP concentration-ratio analyses for TSS, a total of 17 North Carolina SELDM sites were available for analysis. Among these 17 sites, 2 were bioretention BMP type, 13 were grass swale BMP type, and 2 were wetland channel BMP type (Granato, 2014). Among the 13 grass swale sites, 1 highway-runoff and BMP site pair was removed because 100 percent of the efficiency ratios were greater than or equal to 1 . No other sites were removed from the analyses. In the national BMP study, Granato (2014) used data for six North Carolina sites, which were obtained from the International Stormwater BMP Database. These six sites are identical to those in HRDB dataset 19 (Winston and others, 2011) (table 5). Four of the six were grass swale BMP type, and the remaining two were wetland channel BMP type.

A total of two sites were used to compute the North Carolina SELDM medians for minimum, LBMPV, UBMPV, and maximum for the bioretention BMP type (table 13). Only one of the median statistics (maximum) was outside the 95-percent confidence interval of the median statistics for the national study sites (Granato, 2014) and thereby considered to be statistically different from the national median. For the grass swale BMP type, a total of 12 sites (including the 4 used by Granato [2014]) were used to compute the North Carolina SELDM median statistics. None of the North Carolina median statistics were determined to be statistically different from national BMP statistics. This observation is echoed in figure 13, which shows SSC distribution curves for the 12 sites and the North Carolina and national medians for the grass swale BMP type. The two median curves are similar in terms of concentration-ratio ranges, almost overlying each other. Only two sites were available for the wetland channel BMP type (both were used by Granato [2014]) to compute the North Carolina SELDM medians for minimum, LBMPV, UBMPV, and maximum; none were determined to be statistically different from the national medians.

\section{Total Nitrogen}

For BMP concentration-ratio analyses for TN, a total of 17 North Carolina SELDM sites were available for analysis: 2 bioretention BMP type, 13 grass swale BMP type, and
2 wetland channel BMP type (Granato, 2014). None of the sites had more than 70 percent of efficiency ratios greater than or equal to 1. In the national BMP study, Granato (2014) used data for six North Carolina sites, which were obtained from the International Stormwater BMP Database. These six sites are identical to those in HRDB dataset 19 (Winston and others, 2011) (table 5). Four of the six were grass swale BMP type, and the remaining two were wetland channel BMP type.

A total of two sites were used to compute the North Carolina SELDM medians for minimum, LBMPV, UBMPV, and maximum for the bioretention BMP type (table 14). None were determined to be statistically different from the national medians (Granato, 2014). Among the 13 sites — including the 4 used by Granato (2014) — used to compute the North Carolina SELDM medians for minimum, LBMPV, UBMPV, and maximum for the grass swale BMP type, none of the North Carolina median statistics were determined to be statistically different from the national BMP statistics. For the wetland channel BMP type, only two sites (both were used by Granato [2014]) were used to compute the North Carolina SELDM medians for minimum, LBMPV, UBMPV, and maximum. Similar to the grass swale BMP type, none were determined to be statistically different from the national medians.

\section{Total Phosphorus}

For BMP concentration-ratio analyses for TP, a total of 17 North Carolina SELDM sites were available for analysis. Among these 17 sites, 2 were bioretention BMP type, 13 were grass swale BMP type, and 2 were wetland channel BMP type (Granato, 2014). Of the 13 grass swale sites, a total of 4 highway-runoff and BMP site pairs were removed because more than 70 percent of the efficiency ratios were greater than or equal to 1 ( $76,85,87$ and 88 percent). No bioretention or wetland channel sites were removed. In the national BMP study, Granato (2014) used data for six North Carolina sites, which were obtained from the International Stormwater BMP Database. These six sites are identical to those in HRDB dataset 19 (Winston and others, 2011) (table 5). Four of the six were for the grass swale BMP type, and the remaining two were for the wetland channel BMP type.

A total of two sites were used to compute the North Carolina SELDM medians for minimum, LBMPV, UBMPV, and maximum for the bioretention BMP type; none were determined to be statistically different from the national statistics (table 15). A total of nine sites (including the four used by Granato [2014]) were used to compute the North Carolina SELDM medians for minimum, LBMPV, UBMPV, and maximum for the grass swale BMP type. None were determined to be statistically different from the national medians. For the wetland channel BMP type, only two sites (both were used by Granato [2014]) were used to compute the North Carolina SELDM medians for minimum, LBMPV, UBMPV, and maximum. Similar to the grass swale 
sites, none were determined to be statistically different from the national medians.

\section{Nitrate Plus Nitrite}

For the BMP concentration-ratio analyses for nitrate plus nitrite, a total of 17 North Carolina SELDM sites were available for analysis. Among these 17 sites, 2 were bioretention BMP type, 13 were grass swale BMP type, and 2 were wetland channel BMP type (Granato, 2014). None of the sites had more than 70 percent of efficiency ratios greater than or equal to 1. Granato (2014) did not use any North Carolina sites for nitrate plus nitrite in the national BMP study.

A total of two sites in North Carolina were used to compute the North Carolina SELDM medians for minimum, LBMPV, UBMPV, and maximum for the bioretention BMP type (table 16). None were statistically different from the national medians. A total of 13 sites were used to compute the North Carolina SELDM medians for minimum, LBMPV, UBMPV, and maximum for the grass swale BMP type. All four North Carolina median statistics were outside the 95-percent confidence interval range of the median statistics for the national study sites (Granato, 2014) and thereby considered to be statistically different from the national statistics. For the wetland channel BMP type, only two sites were used to compute the North Carolina SELDM medians for minimum, LBMPV, UBMPV, and maximum. None were determined to be statistically different from the national medians.

\section{Minimum Irreducible Concentration}

The MICs were determined for the TSS, TN, TP, and nitrate plus nitrite water-quality constituents. Granato (2014) provided robust methods for estimating the MIC, which is the lowest expected effluent concentration from a BMP site or a class of BMPs. As previously discussed, SELDM substitutes the MIC for BMP effluent concentrations that are less than the MIC. The method developed by Scherer and others (2003) to compute site-specific MICs was used in the current study because of its computational simplicity. This method also is described as having the most advantages and the fewest potential disadvantages among the four methods documented in Granato (2014). Tables 13-16 present the MIC statistics computed for the four constituents across the three BMP types.

The sites used to compute MICs were identical to the sites analyzed for the volume-reduction and concentration-ratio statistics, including those sites used by Granato (2014) in the national BMP study. In a manner identical to concentration-ratio analyses, median statistics of the North Carolina SELDM sites and the national BMP study sites were compared via determinations of the confidence intervals for the national sites. The North Carolina median TSS MIC computed for the bioretention BMP type) was outside the 95-percent confidence interval of the median statistic for the national study sites (Granato, 2014) and thereby considered to be statistically different from the national statistics (table 13). The North Carolina median nitrate plus nitrite MIC statistic computed for the grass swale BMP type was identical to the value at the lower end of the 95-percent confidence interval of the median statistics for the national study sites (Granato, 2014) and thereby (for the purposes of comparison) considered to be statistically different from the national medians (table 16). None of the other North Carolina median MIC statistics were statistically different from the national medians.

\section{Example Simulations of the North Carolina-Enhanced SELDM}

Simulations using the North Carolina-enhanced SELDM are described to demonstrate methods for providing risk-based information about potential effects of stormwater runoff on downstream water quality and the potential for mitigating those risks by using BMPs. Risley and Granato (2014) demonstrated example SELDM applications at six highway sites in Oregon, with highway catchment areas ranging from 3.85 to 11.83 acres and upstream-basin drainage areas ranging from 0.16 to $6.56 \mathrm{mi}^{2}$. These example simulations provided information about potential effects of runoff at specific sites, but the lessons learned may not be transferable to other basins in the State. In the current study, hypothetical basins that represent the central tendency of physiographic and hydrologic variables were simulated so that the results would be generally applicable. This approach was used to demonstrate the ranges in the simulated outputs (with and without BMP treatment) based on varying hydrologic and water-quality inputs while holding selected basin characteristics for the upstream basin at constant values. Two hypothetical Piedmont (rural and urban) upstream basins were simulated to demonstrate use of the North Carolina-enhanced SELDM.

\section{Hypothetical Highway Catchment}

For the highway catchment, SELDM allows up to 15 input variables, of which 8 are required. The required variables for the highway catchment are (1) a short, descriptive site name, (2) the drainage area associated with the highway catchment, (3) the longest drainage length, (4) the mean slope of the two drainage lengths between the road divides and the stream crossing, (5) the impervious fraction, (6) the basin development factor (BDF) value, and (7) latitude and (8) longitude coordinates of the point where the highway catchment drains into the stream. The highwaycatchment area is interpretive. For example, users can simulate the pavement only with an impervious fraction of 1 and simulate any swales as part of the selected BMP. Alternatively, the drainage area can be defined as the cumulative sum of areas (in acres) for the pavement, shoulders, median, and any 
side roads that drain to the stream at the highway crossing by selecting an impervious fraction that represents the paved and unpaved areas of the highway catchment. The drainage length (in feet) also is interpretive. The drainage length is the flow path from the drainage divide to the discharge point, which is either at the stream or into the BMP. The drainage length is used to calculate the duration of the discharge hydrograph. If there is more than one drainage length, the longest path would be used. For example, if the site consists of two approaches to a stream and a bridge over the stream, which is drained by scuppers, then the drainage length selected would be for the longest approach. Basin variables can be estimated; exact numbers are not necessary because variations in lagtimes with small differences in hydraulic variables for highway sites commonly are small in comparison to the average storm durations (Granato, 2012, 2013).

For a level-one analysis, the coordinates of the point where the highway catchment drains into the stream determine the ecoregion and rain zone (Granato, 2013) used to calculate prestorm flow and precipitation statistics for the simulations. For a level-two analysis, these coordinates help guide users in the selection of one or more nearby streamgages and precipitation stations used to calculate prestorm flow and precipitation statistics. If an actual site is being simulated, then these coordinates document the site location and can be used to view the site and the surrounding area on web applications like the USGS National Map Viewer (https://viewer.nationalmap.gov/) and to retrieve upstream-basin properties from the USGS StreamStats application (https://streamstats.usgs.gov/ss/).

Given that SELDM was primarily designed for assessing the effects of highway runoff on downstream water quality and evaluating stormwater management alternatives, the highwaycatchment variables will typically be obtained from State department of transportation highway design plans or as-built files following construction. In the absence of such files, coarse estimates of the variables can be generated by using topographic maps, commercial mapping software, or online mapping or aerial photogrammetric resources such as Google Earth. Users are cautioned, however, against using USGS StreamStats applications (Ries and others, 2008) to determine highwaycatchment variables. The digital elevation model terrain layers in StreamStats are commonly not of sufficient resolution and detail to permit reliable estimates, particularly for areas that are much smaller than the upstream basins. Also, for small engineered catchments, the drainage divides and flow paths may be defined by the storm-sewer network design, which may not be congruent to the topography of the surrounding terrain. Specific details on computing drainage length and mean basin slope for SELDM applications are provided in Granato (2012).

The upstream-basin and highway-catchment characteristics for the two hypothetical Piedmont stream-crossing locations in North Carolina are presented in table 17. For all simulations, a hypothetical four-lane highway with two outside shoulder lanes (six lanes total) was developed, with a catchment area set at 10 acres $\left(435,600\right.$ square feet or $\left.0.016 \mathrm{mi}^{2}\right)$. The stream crossing was set at the midpoint of the catchment. The impervious areas were all set at 100 percent, representing a catchment of only pavement cover. With the lane widths set to the 12-foot ( $\mathrm{ft}$ ) standard for interstate highway lane widths (American Association of State Highway and Transportation Officials, 2012) and the stream crossing at the midpoint of the catchment, the total drainage length between the two divides on each side of the stream crossing was $6,050 \mathrm{ft}$. Given that the highwaycatchment drainage length is defined as the longest of the two drainage lengths, the drainage length in this example is simply half of the total drainage length $(3,025 \mathrm{ft}$ for the simulations described in this report).

The mean slope (in feet per mile) for the highway catchment is defined as the average of the two slopes determined for each approach between the road divides and the stream crossing. Given the variation in terrain across North Carolina from the Middle Atlantic Coastal Plain to the Blue Ridge Mountains, there is a wide range of potential mean slopes that can be used as input in SELDM. For the purposes of the simulations described in this report, a mean slope of 50 feet per mile (ft/mi) was selected for the highway approach to the stream crossing. This slope is well below the maximum design slope of about 158 feet per mile ( $\mathrm{ft} / \mathrm{mi}$ ) for 65-mile-per-hour freeways in level terrain (American Association of State Highway and Transportation Officials, 2012).

The BDF is an index of urbanization and the prevalence of engineered drainage features within a drainage basin (Sauer and others, 1983; Masch, 1984; Federal Emergency Management Agency, 2001; McCuen and others, 2002). The $\mathrm{BDF}$ is a numerical value ranging from 0 to 12 that classifies human development and alteration in a drainage basin. A value of 0 represents a basin that is completely undeveloped, and a $\mathrm{BDF}$ of 12 represents a basin that is fully developed with storm sewers and engineered stream channels (Stricker and Sauer, 1982). Additional information about determining BDFs and their relevance in SELDM applications is provided in Granato (2012). SELDM uses the BDF value to estimate the basin lag for highway catchments and upstream basins. Granato (2012) discussed the development of a regression equation (RE07) that allows SELDM to estimate the basin lag by using the basin lag factor and the BDF value. Granato (2012) also presented a regression equation (RE13) that predicts the basin lag using the impervious area of the drainage basin. SELDM users can determine the basin lag by using either the BDF value or the impervious area (Granato, 2013). Users can specify a BDF that will be used to determine the basin lag (equation 21 in Granato [2013]). Users can also specify a BDF alternate value of -1 , which directs the model to use the RE13 regression equation (Granato, 2012) to compute the basin lag using the basin lag factor and total impervious area (equation 22 in Granato, 2013). The BDF alternate value of -1 was used for the hypothetical highway in all SELDM simulations completed for this report. 
Table 17. Summary of site characteristics for a hypothetical North Carolina upstream basin and a hypothetical four-lane highway used for North Carolina Stochastic Empirical Loading and Dilution Model (SELDM) simulations.

[Characteristics in blue-shaded cells were held constant in simulations for both rural and urban upstream basins. Predicted channel lengths and slopes for the upstream basin were estimated by using relations developed from analysis of 123 selected U.S. Geological Survey streamgages in North Carolina, South Carolina, Georgia, and Tennessee. A basin development factor (BDF) value of -1 directs the SELDM application to use impervious area rather than the BDF to calculate basin lag. The highway mean slope was set at 50 feet per mile (ft/mi) for the purposes of simulations. $\mathrm{ft}$, foot; $\mathrm{mi}^{2}$, square mile]

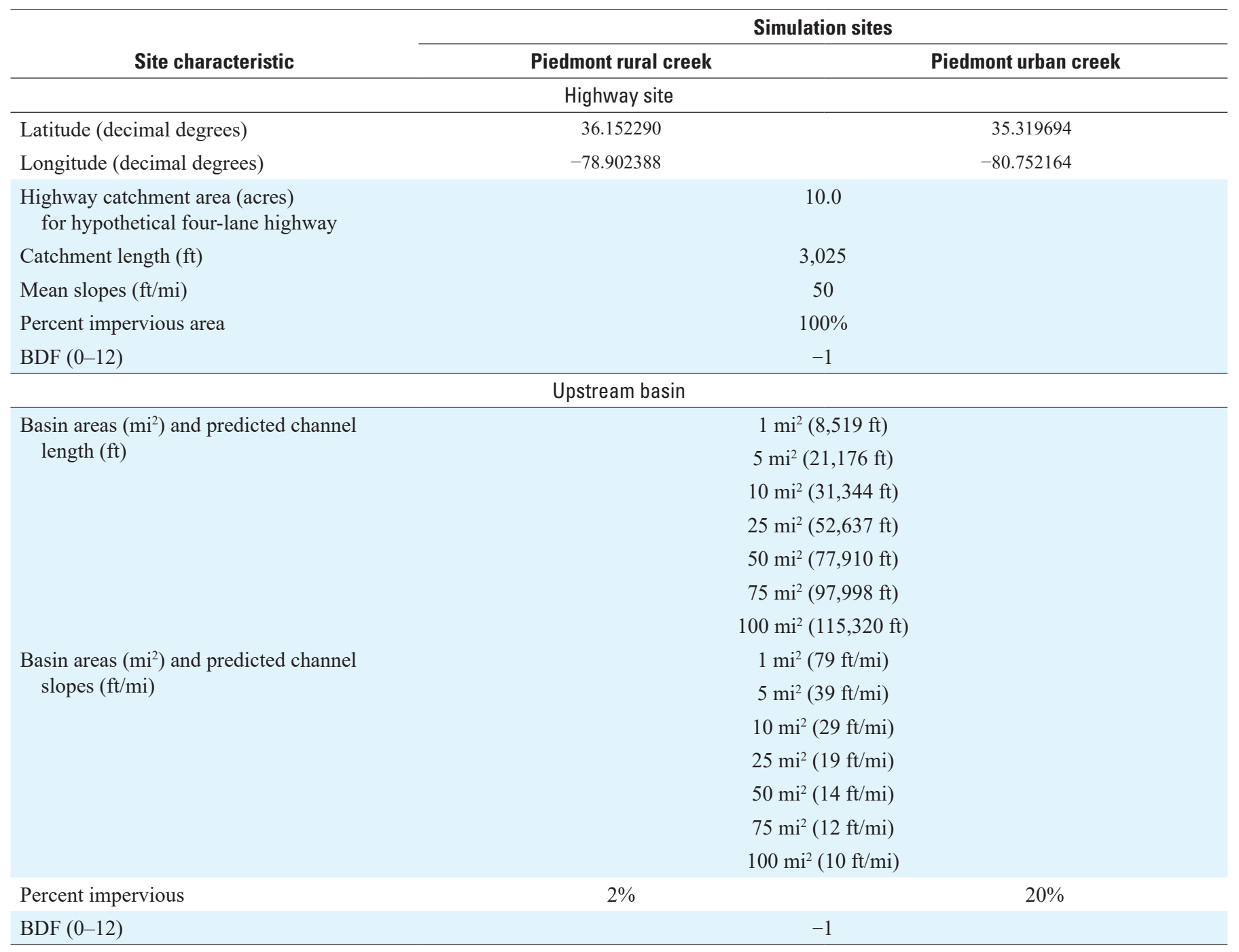




\section{Hypothetical Upstream Basins}

SELDM allows up to 11 input variables for the upstream basin, of which 8 are required. Users can obtain four of these required variables through the USGS StreamStats application (https://streamstats.usgs.gov/ss/): (1) drainage area in $\mathrm{mi}^{2}$ (DRNAREA in StreamStats), (2) drainage length or length of longest flow path in $\mathrm{ft}$ (LFPLENGTH in StreamStats), (3) mean basin slope in $\mathrm{ft} / \mathrm{mi}$ (CSL10_85fm in StreamStats), and (4) impervious fraction (LC11IMP in StreamStats). The four remaining required input variables are the BDF, which was set at a value of -1 for the simulations described in this report, and the three variables that describe the triangular hydrograph recession ratios (minimum, most probable value, and maximum), which are shown in table 4 . The impervious areas used in the simulations for the two hypothetical Piedmont upstream basins was set at either 2 percent (to represent a hypothetical rural basin) or 20 percent (to represent a developed or urban basin). USGS floodfrequency studies commonly use an impervious threshold of 10 percent to represent urban basins (Weaver and others, 2009). Upstream-basin characteristics for two hypothetical Piedmont stream locations in North Carolina are presented in table 17. The drainage areas selected for the initial group of simulations range from 1 to $100 \mathrm{mi}^{2}$. However, it should be acknowledged that an impervious area of 20 percent commonly does not occur for the higher drainage areas used for the first group of simulations.

Drainage lengths and channel slopes vary among the drainage areas. The drainage lengths and channel slopes were analyzed to provide reasonable planning-level estimates of these basin properties as a function of drainage area. These basin properties were used to develop example simulations to explore the potential effects of runoff from a hypothetical highway site on water quality in receiving streams with various drainage areas. Basin properties from the 123 basins in Georgia, South Carolina, and North Carolina that were used to represent the physiography of North Carolina's stream basins were retrieved from the basin lagtime compilation database (Granato, 2012). Both the drainage length and channel slope were strongly correlated to drainage area with Spearman's rho values of 0.9777 and -0.8056 , respectively. Therefore, regression relations (eqs. 1 and 2) were developed by using the Kendall-Theil Robust Line program (Granato, 2006).

$$
\text { Length }=1.6135 \times \text { DrainageArea } a^{0.56575}
$$

and

$$
\text { Slope }=78.56 \times \text { DrainageArea }^{-0.43758}
$$

Where

$$
\begin{aligned}
& \text { DrainageArea } \text { is the basin drainage area, in square miles; } \\
& \text { Length } \text { is the drainage length, in miles; and } \\
& \text { Slope } \text { is the channel slope in feet per mile (known } \\
& \text { as the 10-85 slope because it is calculated } \\
& \text { by using the elevations at points that are } \\
& \text { at } 10 \text { and } 85 \text { percent of the main channel } \\
& \text { length from the point of interest to the } \\
& \text { drainage divide). }
\end{aligned}
$$

The data and linear regression models for these variables are shown in figure 14. The predicted drainage lengths and channel slopes computed on the basis of drainage area are listed in table 17. 


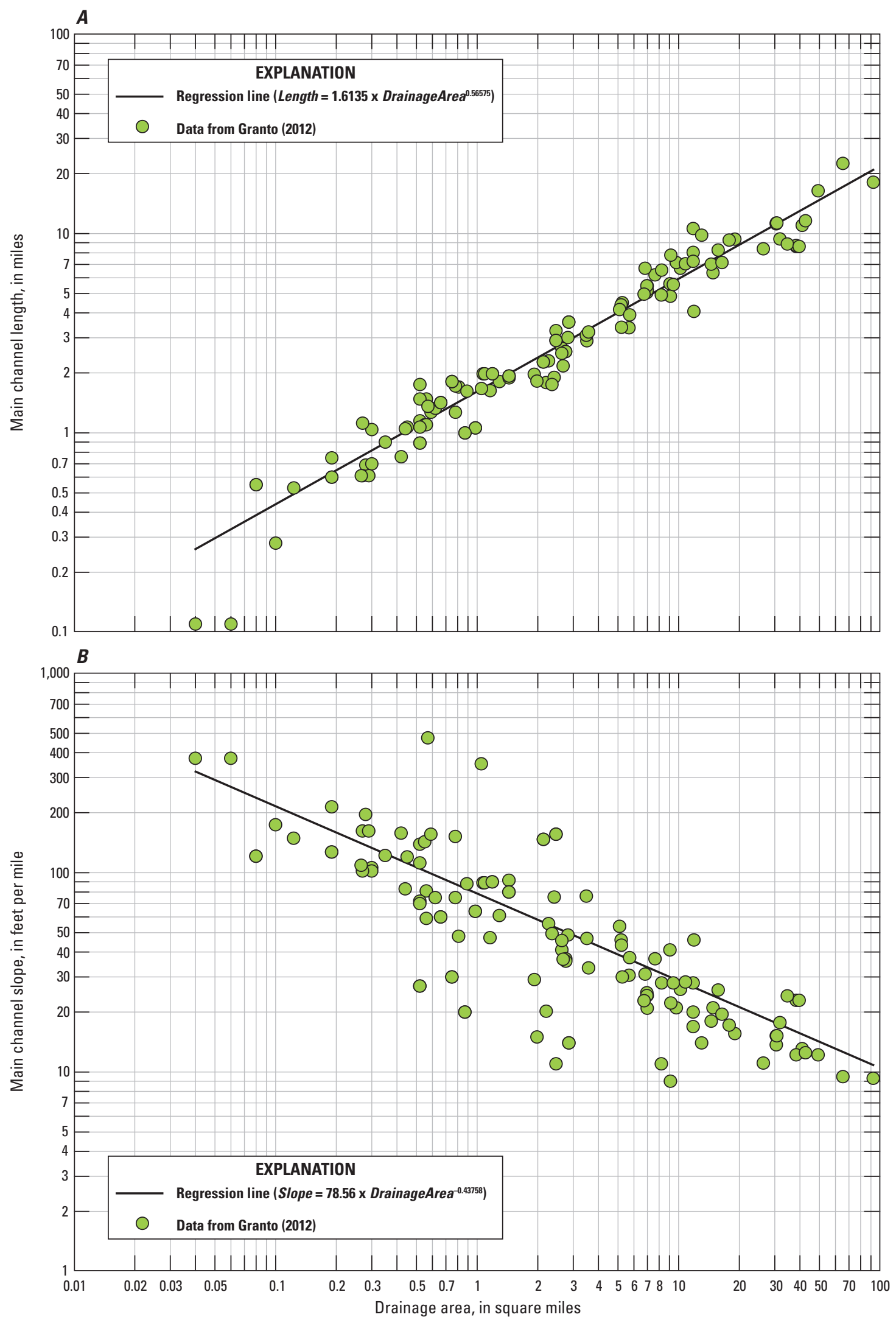

Figure 14. Scatterplots showing the relations between $(A)$ drainage area and drainage length and $(B)$ drainage area and channel slope for selected basins in Georgia, South Carolina, and North Carolina. Data are from the basin lagtime compilation database (Granato, 2012). 


\section{Simulations Group 1: Varying Drainage Area for Upstream Basin}

The first group of simulations was completed to explore the stochastic variability in dilution factors for the hypothetical Piedmont rural creek having varying drainage areas. The dilution factor, which is unitless and ranges from 0 to 1 , represents the ratio of the highway-runoff (or BMP discharge) volume to the total downstream stormflow volume (Granato, 2013). The total downstream stormflow consists of the highway runoff plus the concurrent upstream-basin stormflow. A dilution factor near 0 indicates the highway runoff is a negligible proportion of the total downstream stormflow and represents nearly full dilution of the highway runoff. A dilution factor near 1 indicates the total downstream stormflow consists mostly of highway runoff with little to no dilution.

A total of 14 simulations were completed using the North Carolina-enhanced SELDM for the hypothetical highway crossing over a Piedmont rural creek with varying drainage areas of $1,5,10,25,50,75$, and $100 \mathrm{mi}^{2}$ (table 17). Drainage lengths and channel slopes were estimated using the relations described for upstream basins (eqs. 1 and 2), and the upstream-basin imperviousness was held constant at 2 percent. Precipitation statistics were based on the Piedmont ecoregion average from the FHWA 2010 dataset (Granato, 2010). Streamflow statistics of the six streamgages nearest latitude 36.152290 and longitude -78.902388 were averaged for use in the simulations (with the number of nearest streamgages being chosen for the purposes of the simulations). Based on the average statistics of these six nearest streamgages, geometric $\log 10$ mean streamflow of $0.2482\left(\mathrm{ft}^{3} / \mathrm{s}\right) / \mathrm{mi}^{2}$, geometric $\log 10$ standard deviation and skew of 5.002 and -0.1455 , respectively, and fraction of zero flow equal to 0.03769 were used for these simulations. For each drainage area, one simulation was completed without BMP statistics, and a second simulation was completed using the volume-reduction statistics for grass swale BMPs (table 11). The dilution factors determined for each drainage area without and with the BMP statistics are presented in figure 15, which shows the percentage of simulated storm events in which the dilution factor was equaled or exceeded.

The dilution factors decrease with increasing upstream areas because prestorm flow and runoff increase with increasing area (fig. 15). Storm events with large dilution factors commonly are short, intense storms with little prestorm flow. Storm events with small dilution factors commonly are long, low-volume storms with large prestorm flows. Among the simulations without BMP treatment, the maximum dilution factors range from 0.54 to 0.94 , the median dilution factors range from 0.0065 to 0.11 and the minimum dilution factors range from 0.000073 to 0.0071 as drainage area increases from 1 to $100 \mathrm{mi}^{2}$ (fig. 15A). The range in minimum dilution factors, which is controlled by the prestorm flow volume, corresponds to the range in basin sizes. The large dilution factors, however, are less variable than the small values because the large dilution factors are influenced by the timing of the runoff from the upstream basin and are based on the amount of upstream stormflow that occurs concurrent to the highway runoff. It should also be noted that the basin lagtime is longer for larger drainage areas, suggesting the possibility that highway-runoff discharge may cease before the peak discharge occurs, resulting in little to possibly no dilution of the highway runoff (large dilution factor during initial period of upstream runoff).

Comparisons between the dilution factors with and without BMP treatment indicate the potential effectiveness of the BMP for reducing the percentage of dilution factors that equal or exceed a given value (fig. 15). By reducing highway flows, the selected BMPs reduce the dilution factors. Among the simulations including the grass swale BMP treatment statistics (table 11), the maximum dilution factors range from 0.45 to 0.92 , the median dilution factors range from 0.0041 to 0.073 , and the minimum dilution factors range from 0.000026 to 0.0025 as drainage area increases from 1 to $100 \mathrm{mi}^{2}$ (fig. 15B). For events in which the downstream flow is almost entirely highway runoff, even a large reduction in runoff may not substantially decrease the dilution factor. For example, for downstream flow that consists of 99 units of highway runoff and 1 unit of upstream flow, the dilution factor would be 0.99 . In that case, a 50-percent reduction in highway runoff would result in downstream flow that is 49.5 units of highway runoff and 1 unit of upstream flow, resulting in a dilution factor of 0.98. Each of the flow variables, including BMP performance, is stochastic; therefore, the dilution factor for each storm event reflects the stochastic interaction of several variables. Because the BMP statistics applied to these comparisons is only for the grass swale BMP, other BMP structures that are specifically designed to extend the hydrograph (for example, a detention pond) would likely have a greater effect on increasing the dilution of highway runoff.

The increase in runoff and the shortening of the runoff hydrograph caused by increasing the impervious area from 2 to 20 percent reduced the proportion of highway runoff in downstream flow by a factor of 1.4 , on average. Comparison of the average runoff coefficient associated with each impervious fraction ( 0.1335 for rural and 0.174 for urban) indicated that there would be about 30 percent more runoff from the urban basin than from the rural basin. The additional reduction in the proportion of highway runoff in downstream flow may be attributed to the increase in concurrent runoff that occurs because the urban basin has a shorter basin lagtime. The highest dilution factors are likely to occur if a low (or zero) prestorm streamflow is simulated with a short, intense precipitation event during which the basin lag for the upstream basin is greater than or equal to the duration of the storm event (that is, highway runoff is complete well before the peak of the upstream stormflow); this would be a runoff-dominated event.

For the purposes of comparison and discussion, the simulation outputs were used to determine the percentage of storm events in which the dilution factor equaled or exceeded 0.1 , indicating that the downstream flow consists of 10 percent highway runoff and 90 percent upstream flow (table 18). It should be noted the threshold dilution factor of 0.1 was chosen for comparison only; this value has no regulatory significance. 


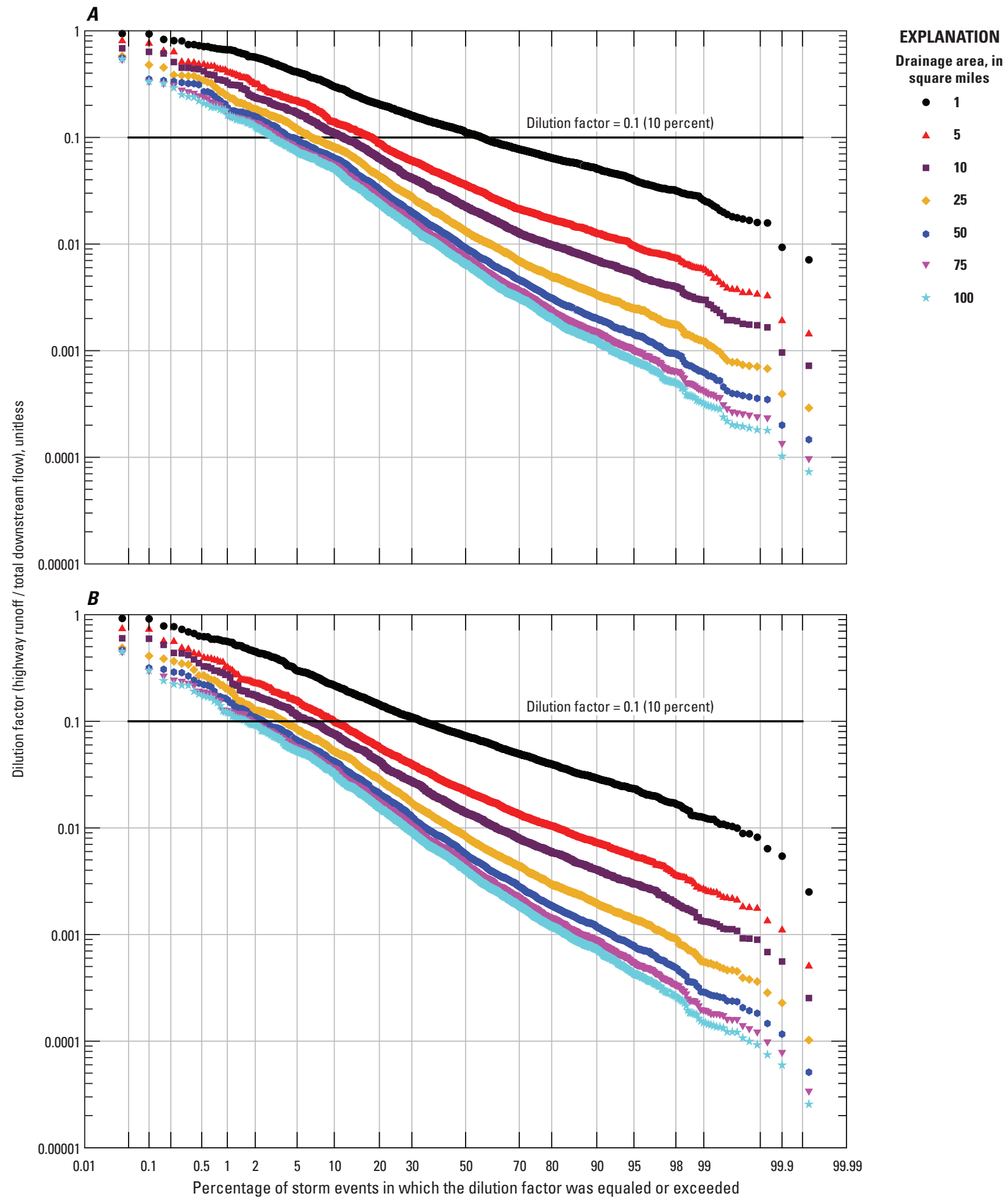

Figure 15. Graphs showing stochastic populations of dilution factors for highway runoff generated $(A)$ without best management practice (BMP) statistics and $(B)$ with volume-reduction statistics for grass swale BMPs for a Piedmont rural basin with drainage areas varying from 1 to 100 square miles. 
Table 18. Percentage of storm events in which dilution factors equaled or exceeded 0.1 for highway runoff without best management practice (BMP) treatment and with volume-reduction grass swale BMP for a Piedmont rural basin with drainage area varying from 1 to 100 square miles $\left(\mathrm{mi}^{2}\right)$.

[Dilution factors represent the ratio of highway runoff to total downstream flow, which consists of highway runoff plus upstream-basin streamflow]

\begin{tabular}{|c|c|c|c|}
\hline \multirow{2}{*}{$\begin{array}{l}\text { Drainage area, } \\
\text { in } \mathrm{mi}^{2}\end{array}$} & \multicolumn{3}{|c|}{ Percentage of storm events in which the dilution factor equaled or exceeded 0.1 (or 10 percent) } \\
\hline & Without BMP & With volume-reduction BMP & $\begin{array}{c}\text { Ratio of with BMP to without } \\
\text { BMP }\end{array}$ \\
\hline 5 & 17.6 & 9.9 & 0.56 \\
\hline 10 & 11.5 & 6.4 & 0.56 \\
\hline 75 & 3.4 & 1.8 & 0.53 \\
\hline 100 & 2.9 & 1.5 & 0.52 \\
\hline
\end{tabular}

The risk of exceeding the selected dilution-factor threshold decreases with increasing drainage area (fig. 15, table 18). As drainage area increases from 1 to $5 \mathrm{mi}^{2}$, the exceedance risk decreases from 56 to 17.6 percent without the BMP and from 33.1 to 9.9 percent with the selected BMP. The risk of exceeding the selected dilution-factor threshold declines to 2.9 percent without the BMP and 1.5 percent with the BMP if the simulated drainage area is $100 \mathrm{mi}^{2}$. The exceedance risk reaches an asymptotic level (6.5 percent without the BMP and 3.7 percent with the selected BMP) at a drainage area of about $25 \mathrm{mi}^{2}$; therefore, this drainage area was used for the example simulations presented in this report.

\section{Simulations Group 2: Varying Precipitation, Upstream Stormflow, and Recession Ratio}

The second group of simulations was completed to examine the effects of varying precipitation, streamflow, and recession ratios on dilution factors. The results of these simulations indicate the sensitivity of the dilution factor to variations in each of the three variables. If simulation results are very sensitive to a given variable, then user selections may be critical to a meaningful result. Otherwise, a robust and defensible estimate may be suitable over a wider range of conditions.

Simulations were completed for two Piedmont upstream basins, both with a drainage area of $25 \mathrm{mi}^{2}$. The first is a rural basin with the impervious area set at 2 percent, and the second is an urban basin with the impervious area set at 20 percent (or one order of magnitude higher). As with the previous group of simulations, the drainage length and channel slope were estimated using the relations described for upstream basins (eqs. 1 and 2). A total of 36 simulations were completed for this group: 18 each for the rural and urban basins. One set of simulations was done by varying precipitation, another set was done by varying prestorm streamflow, and a third set was done by varying the mpvRR to isolate and investigate the potential effects of these three variables on the dilution factor. Each simulation was done with and without the volume-reduction statistics for the grass swale BMP (table 11). As with the first group of simulations, the simulation outputs were used to determine the percentage of storm events in which the dilution factor equaled or exceeded 0.1 (table 19). The threshold dilution factor of 0.1 was chosen for comparison only; this value has no regulatory significance. 
Table 19. Percentage of storm events in which dilution factors equaled or exceeded 0.1 for highway runoff for rural and urban 25-square-mile Piedmont basins based on use of average, minimum, and maximum statistics for selected precipitation, streamflow, and recession ratio Stochastic Empirical Loading and Dilution Model input variables.

[Dilution factors represent the ratio of highway runoff to total downstream flow, which consists of highway runoff plus upstream-basin streamflow. For the purpose of these simulations, the impervious area was set at 2 percent for the rural basin and 20 percent for the urban basin. BMP, best management practice]

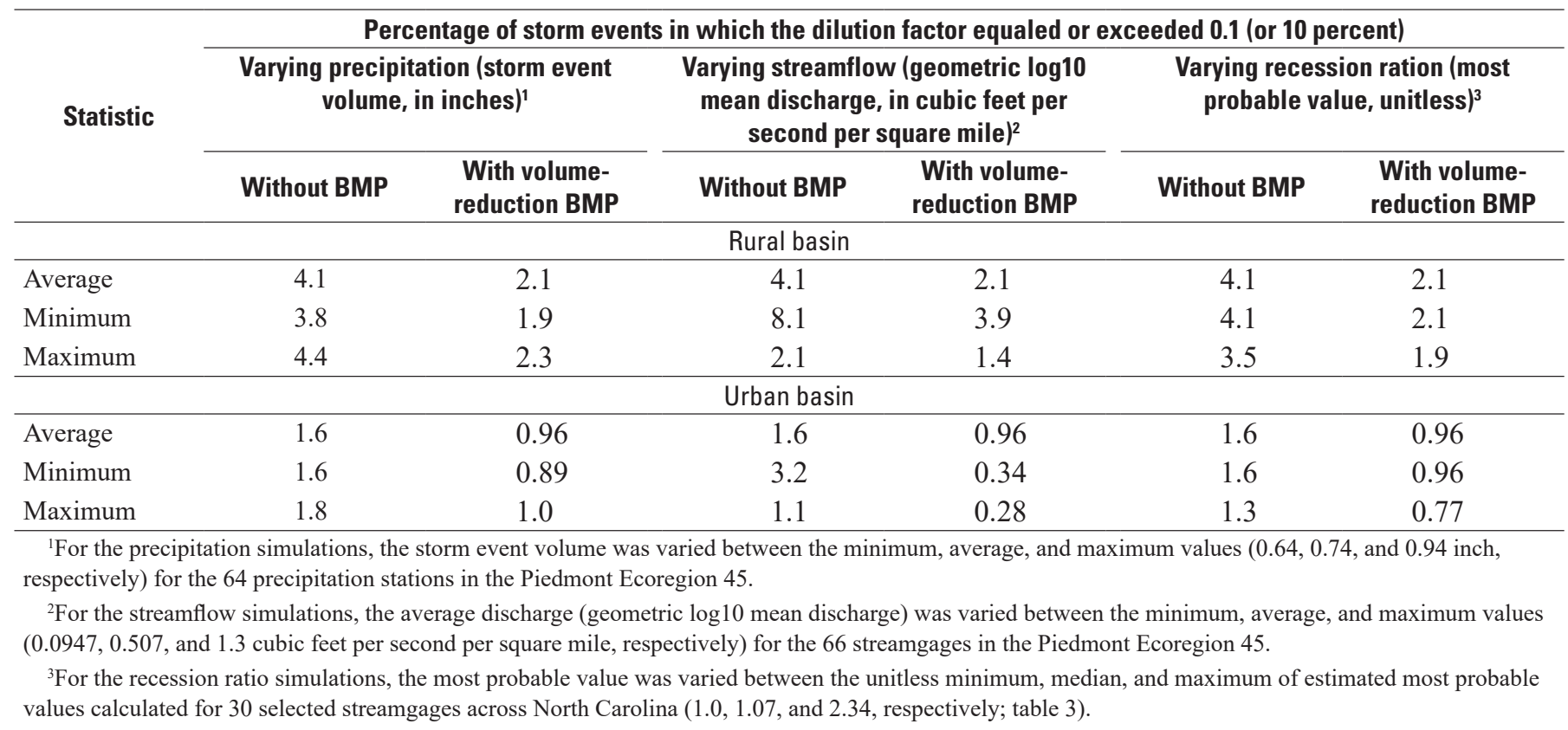

\section{Varying Precipitation: Storm Event Volume}

The first 12 of the 36 simulations focused on the effects of varying precipitation while holding prestorm streamflow and recession ratio input variables constant. SELDM provides several input options for the precipitation statistics: either the average or median precipitation statistics for (1) one or more user-selected precipitation stations, (2) precipitation stations in the rain zone of the upstream basin, and (3) precipitation stations in the ecoregion of the upstream basin. For these 12 simulations, the precipitation storm-event volume was varied between the minimum, average, and maximum values $(0.64$, 0.74 , and 0.94 in., respectively) for the 64 precipitation stations in the Piedmont ecoregion (Ecoregion 45 in the FHWA 2010 dataset [Granato, 2010]). All other precipitation statistics for the 64 sites (including storm-event duration and time between storm events) were held constant for the purposes of these simulations. Figure 16 presents the dilution factors determined for both basin types (rural and urban) without and with the BMP treatment. Table 19 summarizes the percentage of storm events in which the dilution factor equaled or exceeded 0.1 (10 percent).

The risk of exceeding the selected dilution-factor threshold was lower for the urban basin relative to the rural basin. Varying the precipitation storm-event volume from the minimum (0.64 in.) to the maximum (0.94 in.) resulted in the risk of exceeding the threshold ranging from 3.8 to 4.4 percent in the rural basin without BMP treatment (table 19). In the urban basin, the same variation when applied to the urban basin resulted in the risk of exceeding the threshold between 1.6 and 1.8 percent. With the selected BMP treatment, the risk of exceedance dropped to between 1.9 and 2.3 percent for the rural basin and to between 0.89 and 1 percent for the urban basin (table 19). Figure 16 also shows that the largest dilution factors determined among the three precipitation statistics (minimum, average, and maximum) for the rural basin without the BMP exceed those for the urban basin, on average, by about 87 percent (larger spread between the upper left ends of the curves). Conversely, the smallest dilution factors for the rural basin without the BMP exceed those for the urban basin, on average, by about 2 percent (smaller spread between the lower right ends of the curves). With the selected BMP in effect, the largest and smallest dilution factors for the rural basin exceed those for the urban basin, on average, by about 73 percent and 2 percent, respectively.

The effects of varying precipitation volume are not as pronounced as the effects of differing upstream imperviousness ( 2 percent for the rural basin and 20 percent for the urban basin). The same precipitation volume is used to generate runoff from both the highway and the upstream basin (fig. 2). Therefore, given the same prestorm flow and basin properties, both the highway runoff and upstream stormflow change proportionally, resulting in small differences between the precipitation scenarios. However, the patterns shown in figure 16 illustrate the effects of higher runoff volumes and quicker lagtimes in the urbanized basin, which increase and hasten the upstream flows. Therefore, rural dilution factors are much higher than the urban dilution factors for the precipitationdominated dilution factors in the upper left corner of figure 16 . Conversely, the dilution factors dominated by small prestorm flow are approximately equal among precipitation volume and basin development variables. 


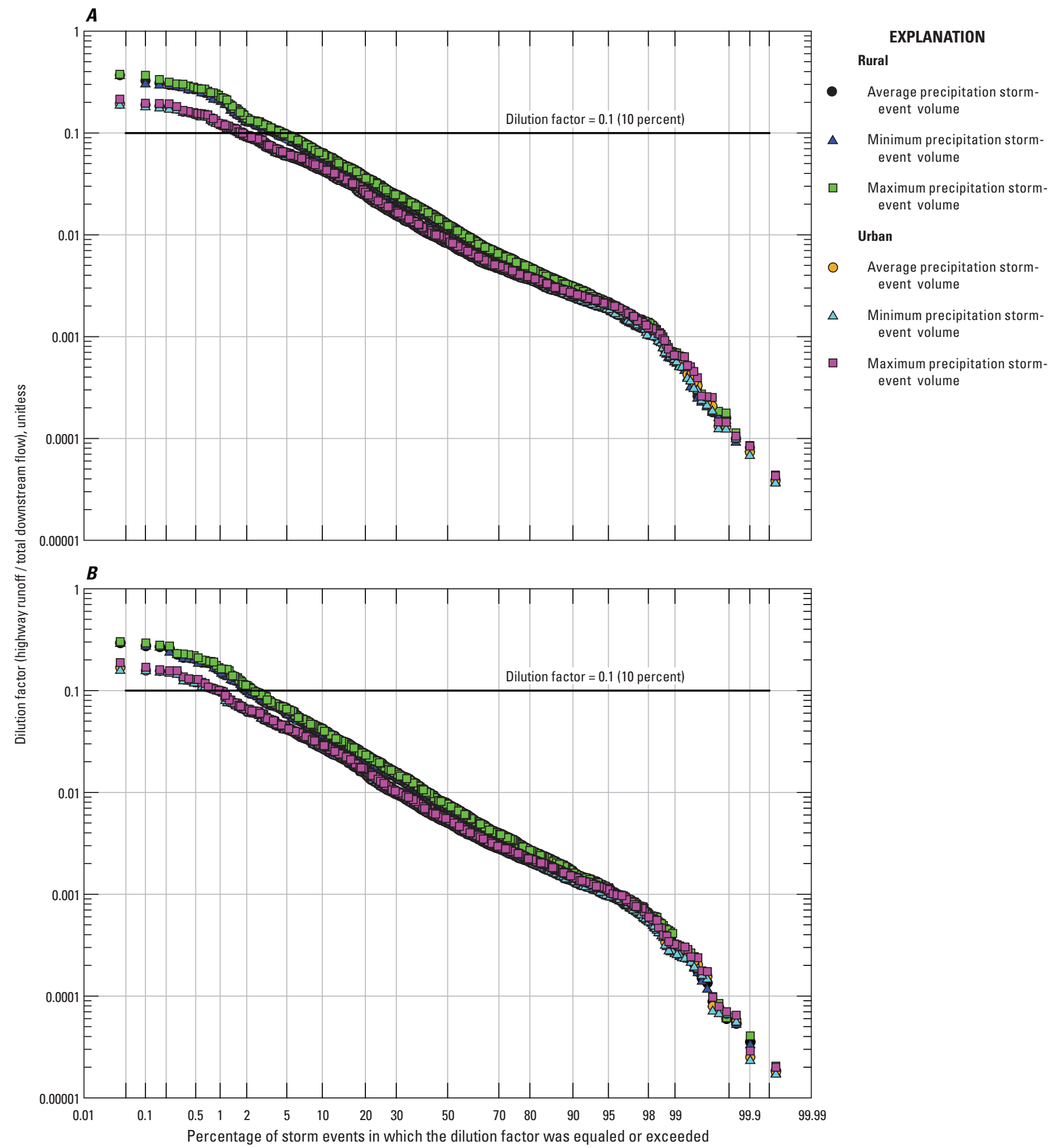

Figure 16. Graphs showing stochastic populations of dilution factors for highway runoff for rural and urban 25-square-mile Piedmont basins based on use of average, minimum, and maximum storm-event volume for the Stochastic Empirical Loading and Dilution Model precipitation stations in the Piedmont ecoregion. Dilution factors were generated $(A)$ without best management practice (BMP) statistics and $(B)$ with volume-reduction statistics for grass swale BMPs. 


\section{Varying Upstream Stormflow: Average Discharge}

The second set of 12 simulations focused on the effects of varying the prestorm streamflow for the upstream basin while holding constant the precipitation and recession ratio input variables. For these 12 simulations, the mean discharge (geometric $\log 10$ mean discharge in $\left[\mathrm{ft}^{3} / \mathrm{s}\right] / \mathrm{mi}^{2}$ ) was varied between the minimum, average, and maximum values $(0.0947$, 0.507 , and $1.3\left(\mathrm{ft}^{3} / \mathrm{s}\right) / \mathrm{mi}^{2}$, respectively) for the 66 streamgages in the Piedmont ecoregion. The statistics for these 66 streamgages are from the North Carolina SELDM streamflow dataset that was developed and pre-loaded in the North Carolina-enhanced SELDM as part of this study. All other streamflow statistics for the 66 streamgages (including standard deviation and skew) were held constant for the purposes of these simulations. Figure 17 presents the dilution factors determined for the rural and urban basins without and with the BMP. Table 19 summarizes the percentage of storm events for which the dilution factor was 0.1 (10 percent) or higher.

The risk of exceeding the selected dilution-factor threshold was determined to be lower for the urban basin relative to the rural basin. Figure 17 indicates a larger spread between the dilution factors based on the varied mean discharge values used relative to those based on the varied precipitation and most probable value recession ratio. Varying the average discharge from the minimum $\left(0.0947\left[\mathrm{ft}^{3} / \mathrm{s}\right] / \mathrm{mi}^{2}\right)$ to the maximum $\left(1.3\left[\mathrm{ft}^{3} / \mathrm{s}\right] / \mathrm{mi}^{2}\right)$ resulted in the risk of exceeding the selected dilution-factor ranging from 2.1 to 8.1 percent in the rural basin without the selected BMP (table 19). The same variation in discharge applied to the urban basin resulted in the risk of exceedance ranging between 1.1 and 3.2 percent. With the selected BMP applied to both basins, the risk of exceedance was between 1.4 and 3.9 percent for the rural basin and between 0.28 and 0.96 percent for the urban basin (table 19).

Figure 17 indicates that the largest dilution factors determined for the rural basin without the BMP are about twice as large as the dilution factors for the urban basin. These differences are indicated by the larger spread between the upper left ends of the dilution-factor probability curves. Conversely, the smallest dilution factors for the rural basin without the BMP are about equal to those for the urban basin, as evidenced by the almost imperceptible spread between the lower right ends of the dilution-factor probability curves. The pattern of variations in figure 17 indicates the effects of prestorm flow on dilution factors. Because the prestorm flow is commonly the dominant variable when dilution factors are small, differences between prestorm flows dwarf the differences caused by impervious runoff when highway runoff is a small proportion of downstream flow. With increasing runoff, however, the selection of the prestorm flow statistic still has a substantial effect on dilution factors. The greater volume and rapid response of urban runoff substantially reduces the proportion of highway runoff in the downstream flow.

\section{Varying Recession Ratio: Most Probable Value Recession Ratio}

The last set of 12 simulations focused on the effects of varying the mpvRR while holding precipitation and prestorm streamflow inputs constant at average values. SELDM allows users to input the minRR, mpvRR, and maxRR values for an upstream basin. For these 12 simulations, the mpvRR was varied between the minimum, median, and maximum (1.0, 1.07, and 2.34, respectively) of estimated mpvRR values calculated for the 30 selected streamgages across North Carolina (table 4). The minRR and maxRR were held constant at median values (1.0 and 4.72, respectively; table 4). Figure 18 presents the dilution factors determined for the rural and urban basins without and with the BMP treatment. Table 19 summarizes the percentage of storm events in which the dilution factor equaled or exceeded 0.1 (10 percent).

As with the simulations done by varying precipitation and prestorm streamflow, the risk of exceeding the selected dilutionfactor threshold was lower for the urban basin relative to the rural basin. The minor difference in the minimum (1.0, unitless) and median mpvRR (1.07) resulted in almost negligible differences between the computed dilution factors. Varying the mpvRR from the minimum (1.0) to the maximum (2.34) resulted in the risk of exceeding the selected dilution-factor threshold ranging from 3.5 to 4.1 percent in the rural basin without the selected BMP (table 19). The same variation when applied to the urban basin resulted in the risk of exceeding the threshold between 1.3 and 1.6 percent. With the selected BMP applied to both basins, the risk of exceedance was between 1.9 and 2.1 percent for the rural basin and 0.77 and 0.96 percent for the urban basin (table 19). As with the other scenarios, the urban and rural dilution factors converge for the prestormflow-dominated dilution factors and diverge as highway runoff becomes the dominant source. The dilution factors for the rural and urban basins are almost identical, indicating that the selection of the recession ratio is not a highly sensitive variable for assessing the potential effect of highway runoff on a receiving stream under the simulated conditions.

The lower risks of exceedances for the urban basin reflect the shorter basin lag relative to that for the rural basin. Using equation RE13 from Granato (2012), the estimated basin lag for the $25-\mathrm{mi}^{2}$ urban basin is about 5.7 hours (estimated drainage length of $52,637 \mathrm{ft}$; channel slope estimated at $19 \mathrm{ft} / \mathrm{mi}$, impervious area of 20 percent). For the $25-\mathrm{mi}^{2}$ rural basin (impervious area of 2 percent), the estimated basin lag is about 6.3 hours. The shorter lag estimated for the urban basin suggests that upstream stormflow was more concurrent with the period of highway runoff, resulting in lower dilution factors. In other words, more dilution of the highway runoff occurred when more of the upstream runoff from the urban basin was still occurring. 


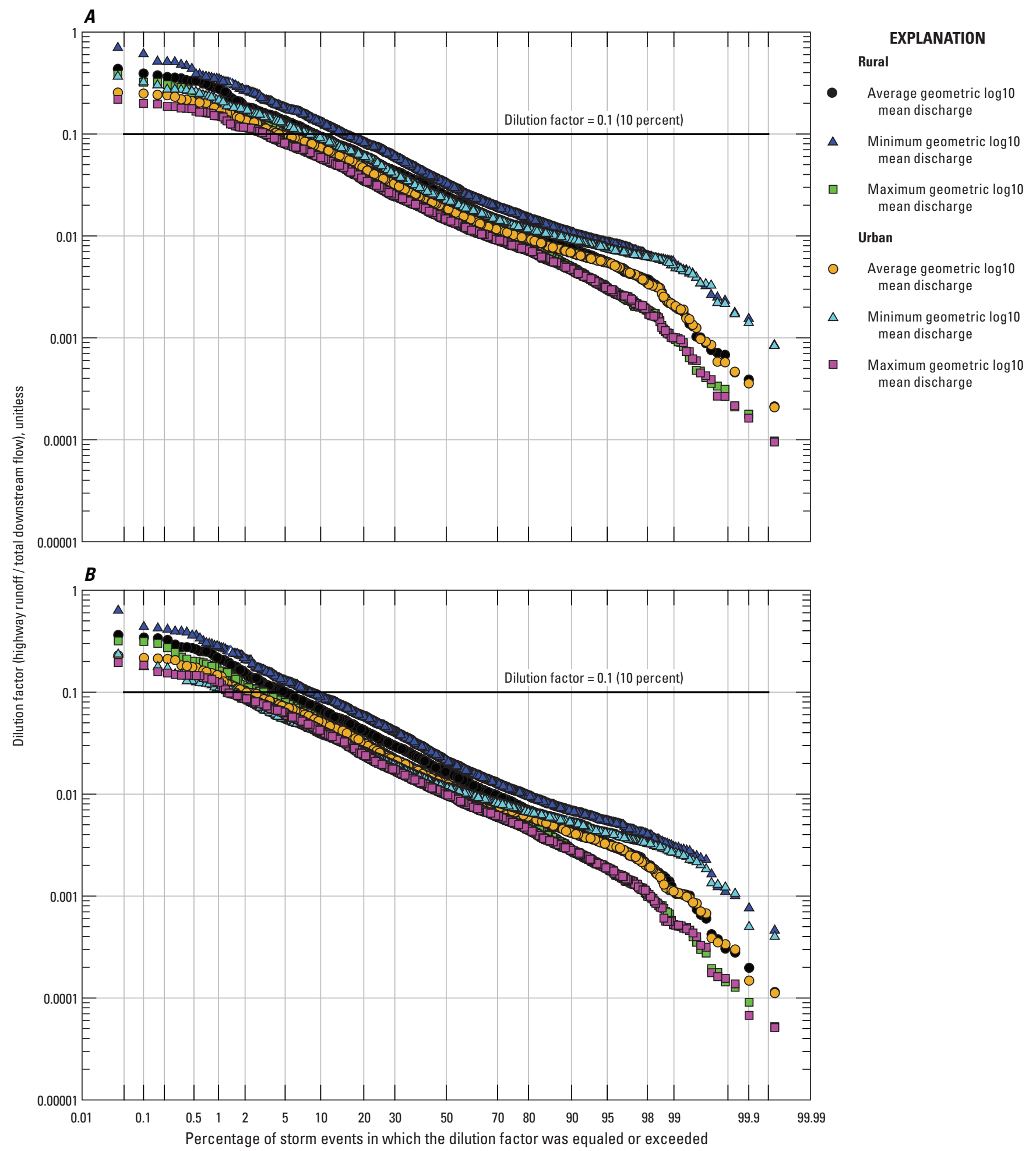

Figure 17. Graphs showing stochastic populations of dilution factors for highway runoff for 25-square-mile rural and urban Piedmont basins based on use of average, minimum, and maximum geometric log10 mean discharge for selected North Carolina Stochastic Empirical Loading and Dilution Model streamgages in the Piedmont ecoregion. Dilution factors were generated $(A)$ without best management practice (BMP) statistics and $(B)$ with volume-reduction statistics for grass swale BMPs. 


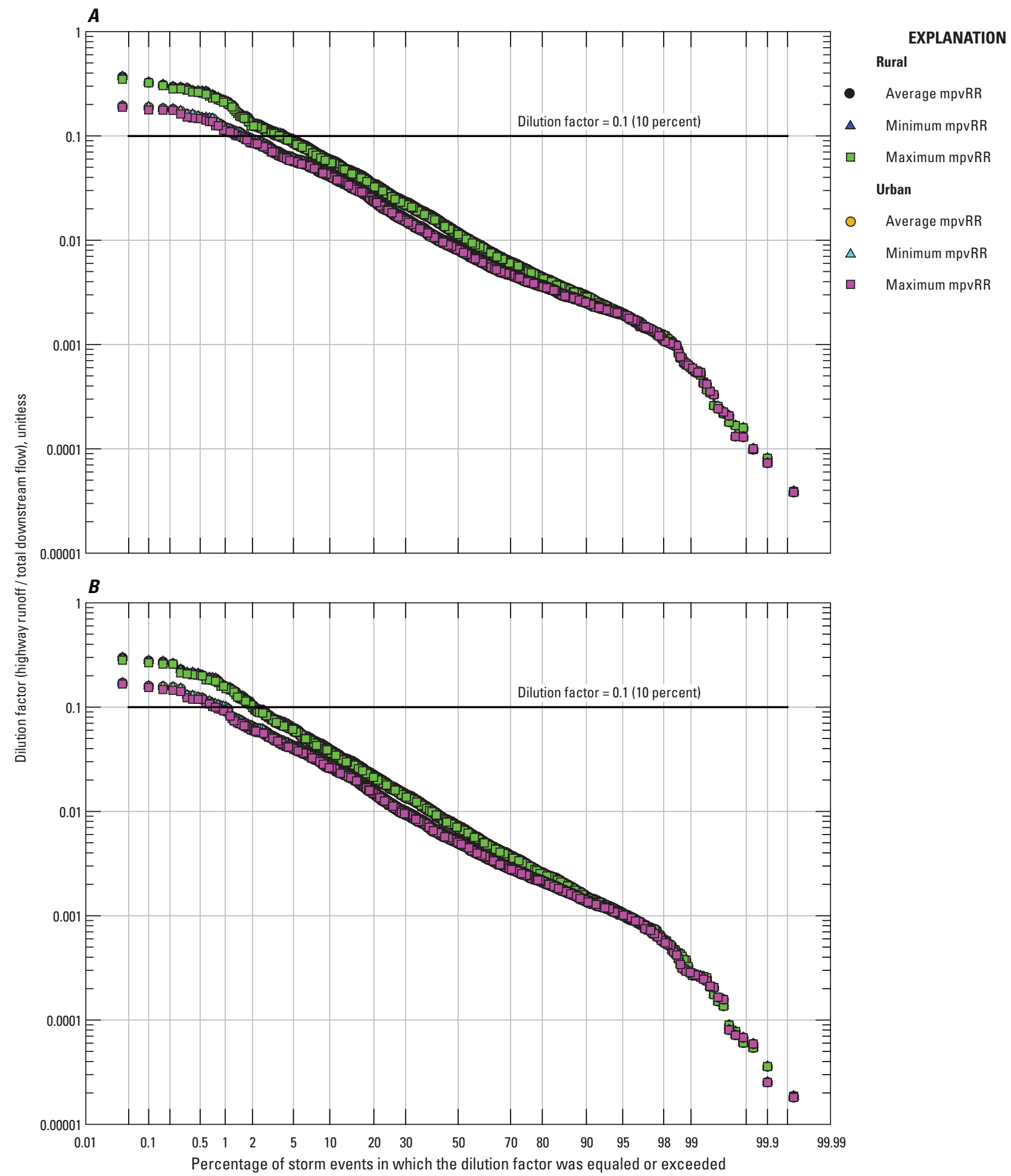

Figure 18. Graphs showing stochastic populations of dilution factors for highway runoff for rural and urban 25-square-mile Piedmont basins based on use of minimum, median, and maximum most probable value recession ratio (mpvRR) for selected North Carolina Stochastic Empirical Loading and Dilution Model streamgages in the Piedmont ecoregion. Dilution factors were generated $(A)$ without best management practice (BMP) statistics and $(B)$ with volume-reduction statistics for grass swale BMPs. 


\section{Simulations Group 3: Varying Upstream Water- Quality Transport Curves}

The third group of simulations was completed to examine the effects of varied concentrations in the upstream basin on water-quality conditions downstream from the highway crossing. Variations in upstream concentrations of three water-quality constituents were simulated by using selected water-quality transport curves from the 57 curves developed for this study (table 8) to represent low-, medium-, and high-concentration statistics. The three waterquality constituents chosen for these simulations were SSC (pcode 80154), TN (pcode 00600), and TP (pcode 00665).

A sufficient number of paired instantaneous streamflow and concentration measurements for the constituent analyses were available at fewer than 20 sites, which is a small fraction of potential monitoring sites in the State. The transport curves selected to simulate low-, medium-, and high-concentration statistics may not be representative of any particular site in the State but are considered representative of the variations in available data. The simulated data should be sufficient for an initial planning-level analysis. If a site of interest is on a sensitive stream or if endangered species are present, then site-specific monitoring data collected over a range of flows and seasons may be needed to refine initial planning-level analyses.

The Piedmont rural creek (impervious area of 2 percent) demonstration site with a drainage area of $25 \mathrm{mi}^{2}$ and mean channel slope of $19 \mathrm{ft} / \mathrm{mi}$ was used for all simulations in this group. The hypothetical highway site (table 17) with a drainage area of 10 acres, drainage length of $3,025 \mathrm{ft}$, drainage slope of $50 \mathrm{ft} / \mathrm{mi}$, and impervious area of 100 percent (all pavement) was also used in this group of simulations. Average precipitation statistics for the 64 precipitation stations in the Piedmont ecoregion (FHWA 2010 dataset [Granato, 2010]) were used in these simulations, and the average prestorm streamflow statistics for the 66 streamgages in the Piedmont ecoregion were used to simulate stormflows from the upstream basin. The statewide median statistics for highway-runoff water quality (table 7) were used to simulate EMCs from the highway catchment. As previously discussed, the user can quickly select regional statistics in a level-one analysis, which may provide the best estimates for sites where limited information is known.

The North Carolina medians determined for the grass swale and bioretention BMP performance statistics for TN and TP concentrations were applied to the water-quality simulations (tables 14 and 15). No North Carolina-specific BMP performance statistics were determined for SSC in this study. In the absence of North Carolina-specific BMP statistics, users can apply the national BMP statistics that were developed and documented by Granato (2014). However, no BMP performance statistics were applied for the SSC water-quality simulations presented in this report. Because these simulations were done solely to demonstrate the concepts of SELDM usage and interpretation of output, this first set of water-quality simulations focuses on comparisons between simulated water-quality concentrations for the upstream basin, highway catchment, and downstream flows only, without consideration of potential BMP treatment.

Water-quality conditions for the upstream basin were varied by selecting three transport curves for each of the simulation constituents. The selected curves were chosen to represent low (good water quality), medium, and high (poor water quality) ranges in simulated concentrations. Figures 10-12, which show the boxplots of simulated EMCs used to evaluate the reasonableness of transport curves developed for this study, were examined. Selection of the transport curves was primarily based on the range between the 25 th and 75 th percentiles of the concentrations relative to the other curves. No interpretation or relation is implied or assumed between the basin characteristics for the streamgage associated with the selected curves and the water-quality concentrations generated from these simulations. The three transport curves were selected solely for the purposes of demonstrating a potential range in simulated EMCs.

A total of 21 analyses were generated for this group of simulations run using the North Carolina-enhanced SELDM. For SSC, three analyses were completed, one for each of the three selected transport curves (low, medium, and high). No BMP statistics were applied for the SSC simulations. For $\mathrm{TN}$, nine analyses were completed, one for each of the three selected curves without BMP, with the grass swale BMP, and with the bioretention BMP. Nine analyses also were completed for TP, similar to the input configurations used for TN.

\section{Varying Suspended Sediment Concentration}

Water-quality transport curves for sites TC19, TC4, and TC20 (table 8, fig. 8) were selected to simulate the low, medium, and high ranges, respectively, of suspended sediment EMCs for the upstream basin. The simulated concentrations are summarized in table 20 and shown in figures 19-21.

Although simulated SSC is presented in this report, it should be acknowledged that TSS is more commonly used by regulatory agencies in the management of water quality in stormwater runoff (Karthik Narayanaswamy, AECOM, written commun., October 3, 2018). However, SSC was used to simulate sediment concentrations rather than TSS because the latter can be an unreliable and biased measure of sediment concentrations in runoff (Bent and others, 2001; Guo, 2006, Waschbusch, 2003; Clark and Siu, 2008; Ying and Sansalone, 2008; Granato and Cazenas, 2009; Selbig and Bannerman, 2011) and in receiving waters (Gray and others, 2000; Galloway and others, 2005, Landers and others, 2007; Coon and others, 2009). Simulating TSS can lead to underestimation of BMP effectiveness (Granato, 2014). Further, using results from 17,701 paired SSC and TSS samples from across the country, the USGS has determined that TSS analyses are "fundamentally unreliable for the analysis of natural-water samples" (Gray and others, 2000, p. 12; U.S. Geological Survey, 2000; Bent and others, 2003). 
Among the 1,633 simulated storm events, SSCs in the highway runoff equaled or exceeded $1.64 \mathrm{mg} / \mathrm{L}$ and $42,400 \mathrm{mg} / \mathrm{L}$ for risks of exceedances corresponding to 99.96 percent and 0.04 percent, respectively, of storm events (the maximum and minimum percentages of storm events, respectively, in the simulations output; table 20). The highway-runoff suspended sediment EMCs associated with risks of exceedances corresponding to 25,50 , and 75 percent of storm events, equaled or exceeded $566 \mathrm{mg} / \mathrm{L}$, $210 \mathrm{mg} / \mathrm{L}$, and $76.2 \mathrm{mg} / \mathrm{L}$, respectively. The 1 -in-3 year risk of exceedance defined by the EPA was computed to be 0.61 percent of storm events, and the simulated EMC at this level of risk equaled or exceeded 12,800 mg/L. Expressed another way, for any given year there is a one-in-three chance that the maximum suspended sediment EMC for the highway runoff would be $12,800 \mathrm{mg} / \mathrm{L}$ or higher.

Figure 19 indicates that the presence of the highwaycatchment area increases downstream suspended sediment EMCs for the entire range of storm events. For about 20 percent or less of the storm events, the increases in downstream suspended sediment EMCs could potentially be substantial on the basis of the upstream-basin concentrations simulated using the low-range transport curve for SSC (site TC19). At risks of exceedances corresponding to 25 , 50 , and 75 percent of storm events, simulated downstream SSC exceed the upstream concentrations by a factor of 1.8 , 1.5 , and about 1.5 , respectively. For about 20 percent of the storm events, the downstream suspended sediment EMCs gradually begin to increase substantially relative to the upstream concentrations (fig. 19). For 2 percent or less of the storm events, the downstream concentrations exceed the upstream concentrations by a factor of 5 or higher because of the presence of the highway-catchment area.

Simulations based on use of the medium-range transport curve (site TC4) for the upstream basin do not suggest any meaningful differences between the upstream and downstream suspended sediment EMCs for the entire range in percentages of storms (fig. 20). The simulations indicate the factor of downstream to upstream concentrations ranged from 1 to 2.6 (table 20), with the downstream concentrations exceeding both upstream-basin and highway-runoff concentrations for less than 1 percent of the storm events (corresponding to 99 percent or higher on the horizontal axis; fig. 20). At the 1-in-3 year risk of exceedance threshold (0.61 percent of storm events), the simulated EMCs for the upstream and downstream runoff equaled or exceeded about $489 \mathrm{mg} / \mathrm{L}$ and $655 \mathrm{mg} / \mathrm{L}$, respectively (downstream concentrations exceed upstream concentrations by a factor of 1.3).

Simulations based on use of the high-range transport curve (site TC20) for the upstream basin similarly do not suggest any meaningful differences between the upstream and downstream SSC for the entire range in percentage of storms (fig. 21). These simulations indicate that the factor of downstream to upstream concentrations commonly ranges from 1 to about 1.2 (table 20), with both upstream-basin and downstream concentrations exceeding the highway-runoff concentrations for 25 percent of the storm events (corresponding to 75 percent or higher on the horizontal axis; fig. 21). At the 1-in-3 year risk of exceedance threshold ( 0.61 percent of storm events), the simulated EMCs for the upstream and downstream runoff are about $2,150 \mathrm{mg} / \mathrm{L}$ and $2,080 \mathrm{mg} / \mathrm{L}$, respectively, a factor of about 0.97 for downstream concentrations relative to upstream concentrations.

The occurrence of a lower downstream concentration at the 1-in-3 year risk of exceedance threshold highlights the uncertainties associated with stochastic modeling outputs and is not reflective of concern regarding the computational algorithms for the SELDM application. Additionally, the nature of the probability plots generated from SELDM output results in concentrations for a given percentage of storm events being from different storm events for the highway, upstream, and downstream runoffs. In other words, highway and upstream points plotted at the same exceedance level are not necessarily from the same storm event (Granato, 2013). Rather, the appropriate interpretation from this last comparison (table 20, fig. 21) is that both upstream and downstream concentrations would equal or exceed about $2,100 \mathrm{mg} / \mathrm{L}$ at the 1-in-3 year threshold level (or 0.61 percent of storm events). 


\section{Assessing Water Quality From Highway Runoff at Selected Sites in North Carolina with SELDM}

Table 20. Simulated suspended sediment concentrations equaled or exceeded in the highway runoff, upstream stormflow, and downstream stormflow for selected percentages of storm events.

[Simulations of upstream runoff were varied to reflect low (good), medium, and high (poor) water-quality conditions, as reflected in selected water-quality transport curves chosen to represent the potential ranges in concentrations. Water-quality concentrations are at or above indicated concentration for selected percentage of storm events. The 1-in-3 year risk is defined by the U.S. Environmental Protection Agency and represents the water-quality concentration that may be equaled or exceeded, on average, once in a 3-year period. See table 8 and figure 8 for information on selected transport curves. $\mathrm{mg} / \mathrm{L}$, milligram per liter; BMP, best management practice; n/a, BMP not applied for simulation of constituent concentration]

\begin{tabular}{|c|c|c|c|c|c|c|c|}
\hline \multirow[b]{2}{*}{ Basin component } & \multirow{2}{*}{$\begin{array}{l}\text { Without } \\
\text { or with } \\
\text { BMP }\end{array}$} & \multicolumn{6}{|c|}{$\begin{array}{l}\text { Simulated suspended sediment concentration equaled or exceeded } \\
\text { for indicated percentage of storm events, in } \mathrm{mg} / \mathrm{L}\end{array}$} \\
\hline & & $\begin{array}{l}0.04 \text { percent } \\
\text { (minimum) }\end{array}$ & 25 percent & 50 percent & 75 percent & $\begin{array}{l}99.96 \text { percent } \\
\text { (maximum) }\end{array}$ & $\begin{array}{c}0.61 \text { percent } \\
\text { (1-in-3 year } \\
\text { risk) }\end{array}$ \\
\hline \multirow[t]{2}{*}{ Highway runoff } & Without BMP & 42,400 & 566 & 210 & 76.2 & 1.64 & 12,800 \\
\hline & With BMP & $\mathrm{n} / \mathrm{a}$ & $\mathrm{n} / \mathrm{a}$ & $\mathrm{n} / \mathrm{a}$ & $\mathrm{n} / \mathrm{a}$ & $\mathrm{n} / \mathrm{a}$ & $\mathrm{n} / \mathrm{a}$ \\
\hline \multicolumn{8}{|c|}{ Upstream water quality simulated for low (good) water-quality conditions (using transport curve for site TC19) } \\
\hline Upstream stormflow & $\mathrm{n} / \mathrm{a}$ & 43.7 & 13.2 & 9.34 & 6.47 & 1.77 & 37.0 \\
\hline \multirow[t]{2}{*}{ Downstream stormflow } & Without BMP & 1,370 & 23.9 & 14.2 & 9.50 & 1.79 & 413 \\
\hline & With BMP & $\mathrm{n} / \mathrm{a}$ & $\mathrm{n} / \mathrm{a}$ & $\mathrm{n} / \mathrm{a}$ & $\mathrm{n} / \mathrm{a}$ & $\mathrm{n} / \mathrm{a}$ & $\mathrm{n} / \mathrm{a}$ \\
\hline \multicolumn{8}{|c|}{ Upstream water quality simulated for medium water-quality conditions (using transport curve for site TC4) } \\
\hline Upstream stormflow & $\mathrm{n} / \mathrm{a}$ & 1,560 & 70.4 & 36.0 & 19.3 & 1.72 & 489 \\
\hline \multirow[t]{2}{*}{ Downstream stormflow } & Without BMP & 1,560 & 86.3 & 47.9 & 27.2 & 4.51 & 656 \\
\hline & With BMP & $\mathrm{n} / \mathrm{a}$ & $\mathrm{n} / \mathrm{a}$ & $\mathrm{n} / \mathrm{a}$ & $\mathrm{n} / \mathrm{a}$ & $\mathrm{n} / \mathrm{a}$ & $\mathrm{n} / \mathrm{a}$ \\
\hline \multicolumn{8}{|c|}{ Upstream water quality simulated for high (poor) water-quality conditions (using transport curve for site TC20) } \\
\hline Upstream stormflow & $\mathrm{n} / \mathrm{a}$ & 4,560 & 275 & 135 & 67.3 & 1.62 & 2,150 \\
\hline \multirow[t]{2}{*}{ Downstream stormflow } & Without BMP & 4,560 & 290 & 149 & 78.7 & 7.25 & 2,081 \\
\hline & With BMP & $\mathrm{n} / \mathrm{a}$ & $\mathrm{n} / \mathrm{a}$ & $\mathrm{n} / \mathrm{a}$ & $\mathrm{n} / \mathrm{a}$ & $\mathrm{n} / \mathrm{a}$ & $\mathrm{n} / \mathrm{a}$ \\
\hline
\end{tabular}




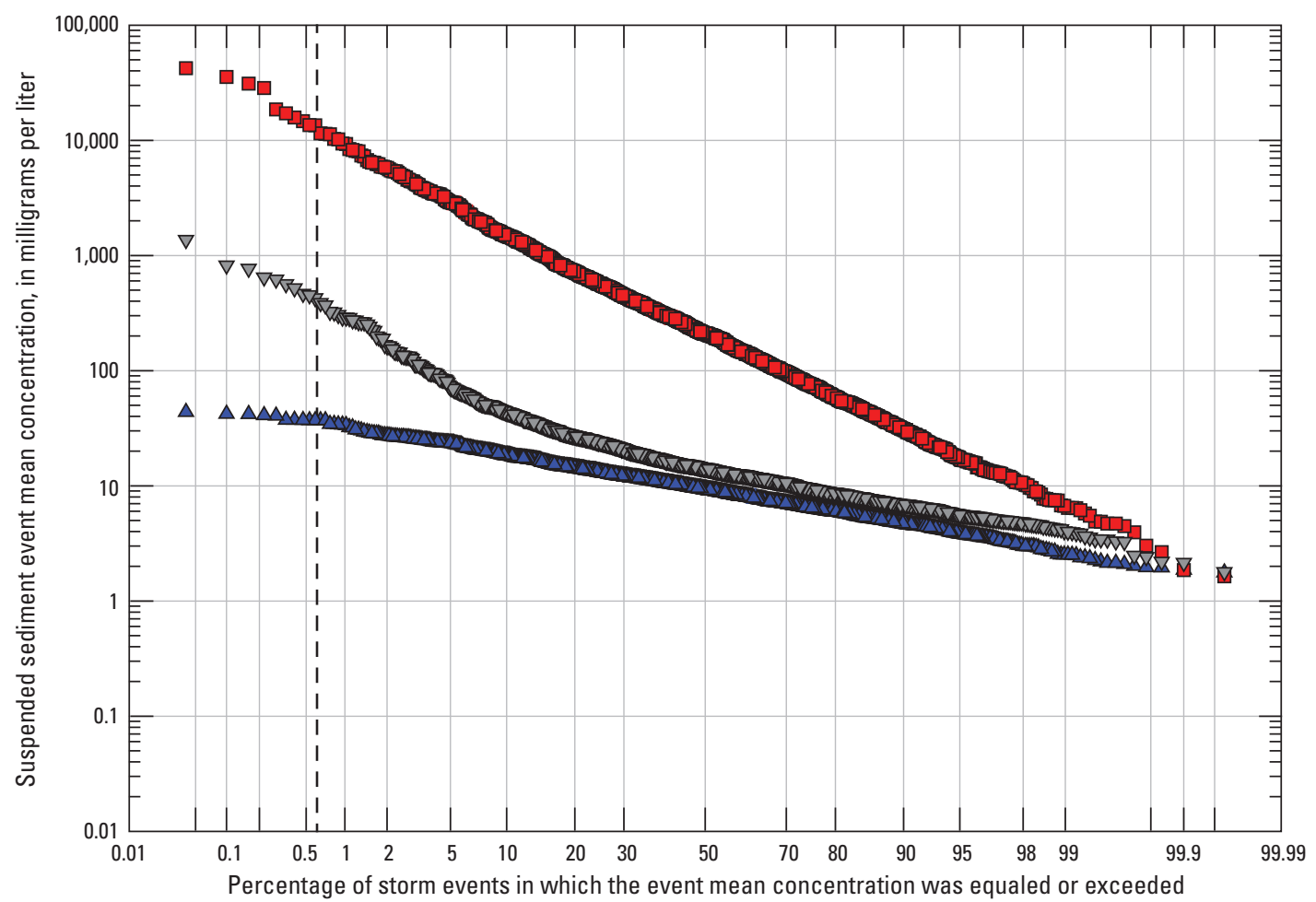

EXPLANATION

Percentage of storm events ( 0.61 percent) corresponding to a 1 -in- 3 year risk of exceedance

$\Delta \quad$ Upstream event mean concentration

- Highway-runoff event mean concentration

$\nabla \quad$ Fully mixed downstream event mean concentration

Figure 19. Graph showing suspended sediment event mean concentrations in upstream flow, highway runoff, and downstream flow simulated for Piedmont rural creek (25-square-mile basin) by using the upstream transport curve for site TC19 (U.S. Geological Survey station 02106500), which represents the low range of potential suspended sediment concentrations from the upstream basin. 


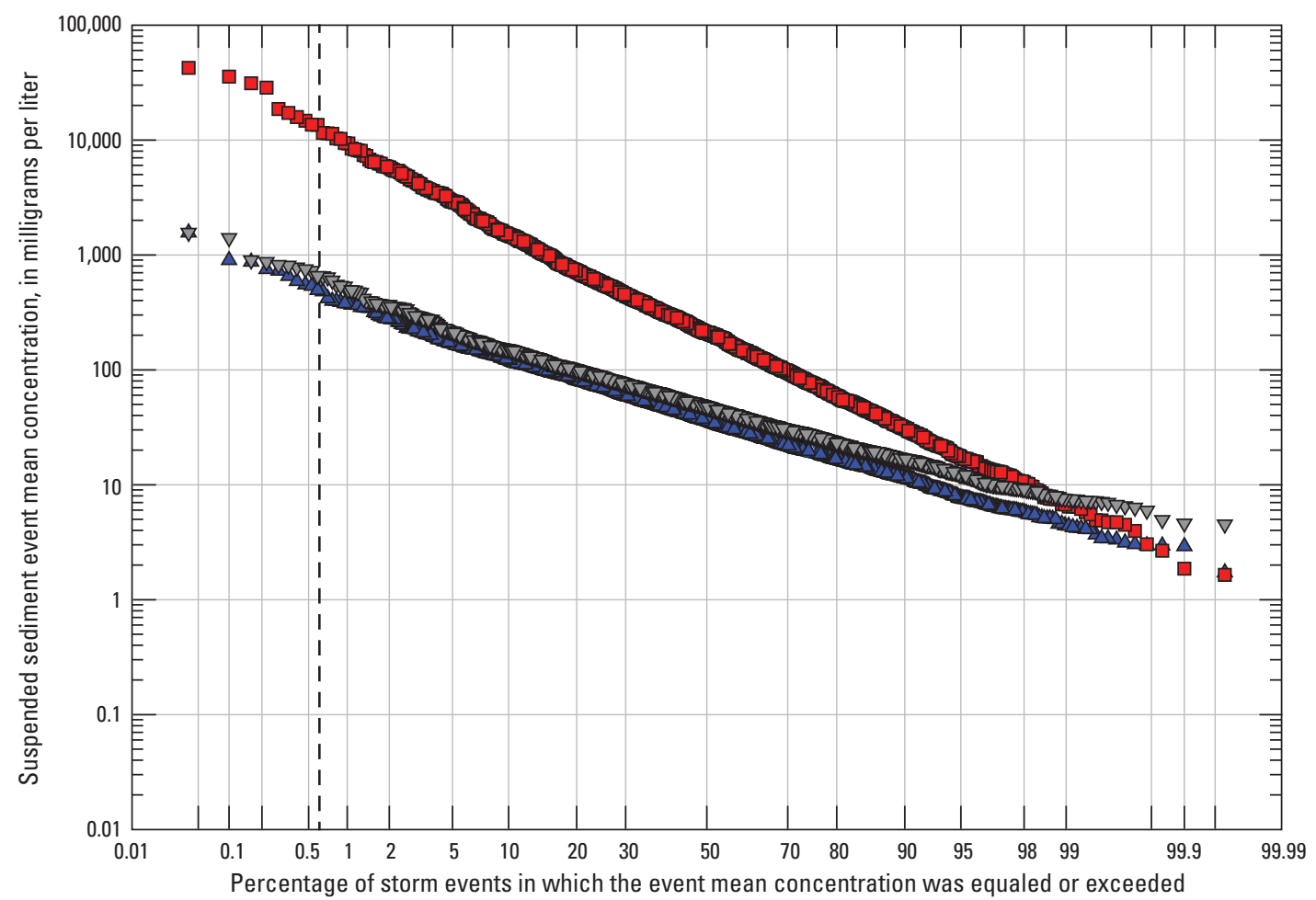

EXPLANATION

Percentage of storm events (0.61 percent) corresponding to a 1 -in-3 year risk of exceedance
$\Delta \quad$ Upstream event mean concentration
․ Highway-runoff event mean concentration
$\nabla \quad$ Fully mixed downstream event mean concentration

Figure 20. Graph showing suspended sediment event mean concentrations in upstream flow, highway runoff, and downstream flow simulated for Piedmont rural creek (25-square-mile basin) by using the upstream transport curve for site TC4 (U.S. Geological Survey station 0208524090), which represents the medium range of potential suspended sediment concentrations from the upstream basin. 


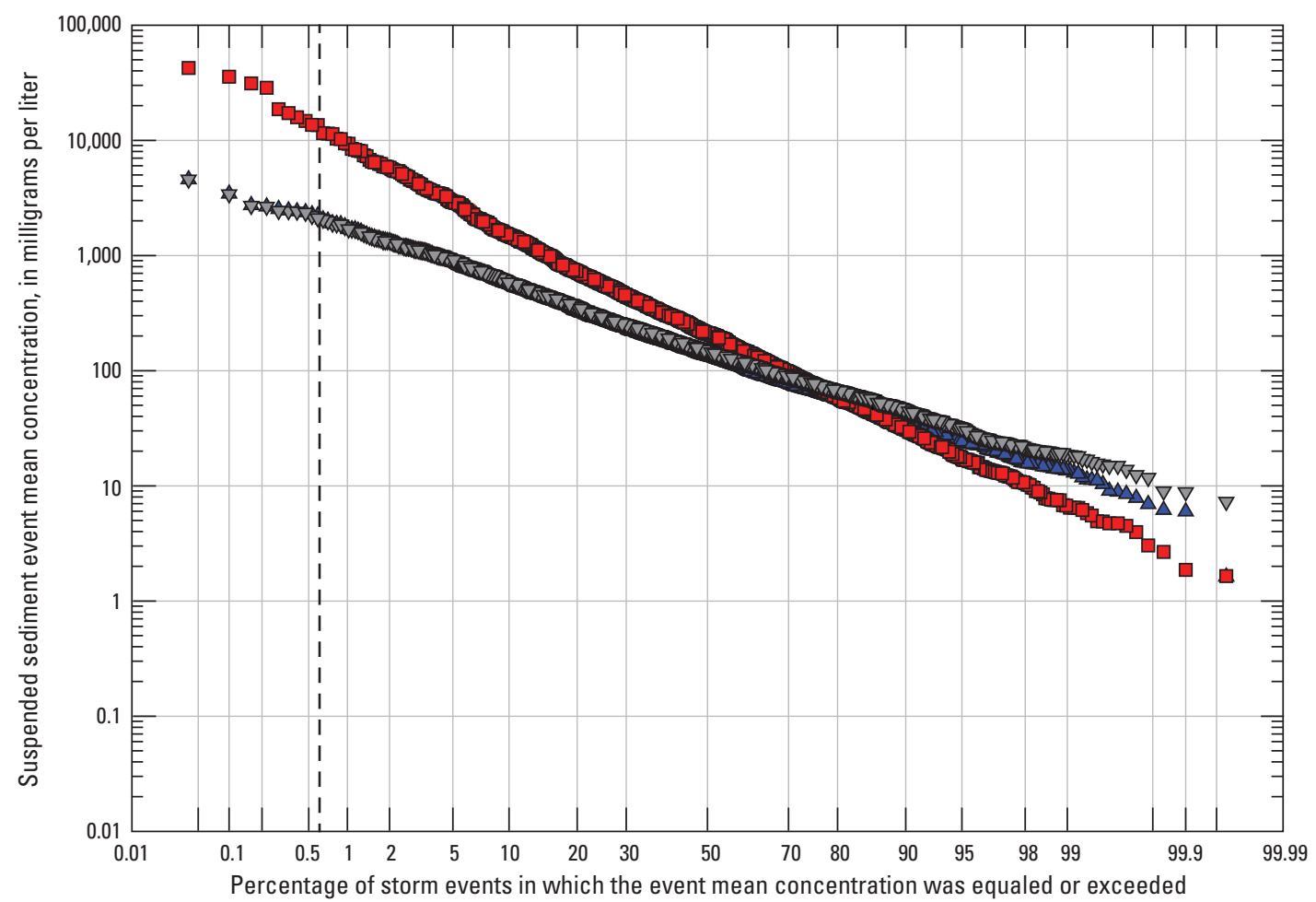

EXPLANATION

Percentage of storm events (0.61 percent) corresponding to a 1 -in- 3 year risk of exceedance

$\Delta \quad$ Upstream event mean concentration

$\square \quad$ Highway-runoff event mean concentration

$\nabla \quad$ Fully mixed downstream event mean concentration

Figure 21. Graph showing suspended sediment event mean concentrations in upstream flow, highway runoff, and downstream flow simulated for Piedmont rural creek (25-square-mile basin) by using the upstream transport curve for site TC20 (U.S. Geological Survey station 0212414900), which represents the high range of potential suspended sediment concentrations from the upstream basin. 


\section{Varying Total Nitrogen}

Water-quality transport curves for sites TC27, TC24, and TC6 (table 8, fig. 8) were selected to simulate the low, medium, and high ranges, respectively, of TN EMCs for the upstream basin. The simulated concentrations are summarized for selected percentages of storm events in tables 21 and 22 and figures 22-24.

TN concentrations simulated among the 1,633 storm events for the highway runoff equaled or exceeded $0.14 \mathrm{mg} / \mathrm{L}$ and about $4.88 \mathrm{mg} / \mathrm{L}$ for risks of exceedances corresponding to 99.96 percent and 0.04 percent of storm events, respectively (table 2). The simulated highway-runoff TN EMCs without BMP treatment associated with the risks of exceedances corresponding to 25,50 , and 75 percent of storm events, equaled or exceeded $1.29 \mathrm{mg} / \mathrm{L}, 0.92 \mathrm{mg} / \mathrm{L}$, and $0.64 \mathrm{mg} / \mathrm{L}$, respectively. At the 1-in-3 year risk of exceedance threshold ( 0.61 percent of storm events), the simulated EMC equaled or exceeded $3.43 \mathrm{mg} / \mathrm{L}$. Expressed another way, for any given year there is a one-in-three chance that the TN EMC for the highway runoff without BMP treatment would be $3.43 \mathrm{mg} / \mathrm{L}$ or higher.

With application of a grass swale BMP treatment, the simulated TN EMCs for the highway runoff equaled or exceeded 0.28 and $5.02 \mathrm{mg} / \mathrm{L}$ for risks of exceedances corresponding to 99.96 percent and 0.04 percent of storm events, respectively (table 21). For about 1 percent of the storm events (corresponding to 99 percent or higher on the horizontal axis; figs. 22-24), the TN EMC was equal to or greater than $0.28 \mathrm{mg} / \mathrm{L}$, a rounded variation of the North Carolina median MIC of $0.275 \mathrm{mg} / \mathrm{L}$ (table 14) determined in the grass swale BMP analyses completed for this study. Compared to the highway runoff without BMP treatment, the simulations indicate use of the grass swale BMP treatment resulted in efficiency ratio values (outflow concentration divided by inflow concentration) commonly ranging from 0.8 to about 1 . Expressed another way, the stochastic modeling using the BMP performance statistics for grass swale may result in a decrease in highway-runoff EMCs for TN between 0 and 20 percent.

Application of a bioretention BMP treatment suggests larger reductions in $\mathrm{TN}$ concentrations for highway runoff relative to no BMP treatment or grass swale BMP treatment. Simulated TN EMCs for highway runoff after bioretention treatment equaled or exceeded 0.17 and $2.9 \mathrm{mg} / \mathrm{L}$ for risks of exceedances corresponding to 99.96 percent and 0.04 percent of storm events, respectively (table 22). For less than 0.5 percent of the storm events (corresponding to about 99.8 percent or higher on the horizontal axis; figs. 22-24), the TN EMC was equal to or greater than $0.17 \mathrm{mg} / \mathrm{L}$, a rounded variation of the North Carolina median MIC of $0.175 \mathrm{mg} / \mathrm{L}$ (table 14) determined in the bioretention BMP analyses completed for this study. Compared to the highway runoff without BMP treatment, use of the bioretention BMP treatment resulted in efficiency ratio values commonly ranging from about 0.46 to about 0.59 . The stochastic output from SELDM incorporating the BMP performance statistics for bioretention suggests that use of this treatment may result in decreased highway-runoff EMCs for TN between 41 and 54 percent, a substantial improvement relative to use of a grass swale for BMP treatment.

Simulations based on use of all three selected transport curves for the upstream basin do not suggest any meaningful differences between the simulated upstream and downstream TN EMCs for the entire range in percentages of storms (tables 21 and 22, figs. 22-24). Further, upstream and downstream concentrations simulated using the mediumand high-range transport curves (sites TC24, and TC6, respectively) exceed the highway-runoff concentrations (by almost an order of magnitude for all percentages of storm events shown on the $\mathrm{x}$-axis of figure 24 for simulations based on the high-range transport curve).

Application of either the grass swale or bioretention BMP treatments to the highway runoff did not reduce concentrations downstream from the highway site (tables 21 and 22). When considering the potential uncertainties associated with outputs from the stochastic modeling combined with rounding of results, the downstream concentrations were practically equal to the upstream concentrations. For example, use of the medium-range transport curve for the upstream basin indicates the $\mathrm{TN}$ concentration for both upstream and downstream runoff would equal or exceed $1.20 \mathrm{mg} / \mathrm{L}$ for the risk of exceedance corresponding to 50 percent of the storm events, without or with BMP treatment using a grass swale (table 21). At the 1-in-3 year risk of exceedance threshold ( 0.61 percent of storm events), the simulated EMC for the upstream and downstream runoff would equal or exceed $4.34 \mathrm{mg} / \mathrm{L}$ (table 21). The bioretention simulations likewise did not result in appreciable reductions in concentrations. Use of the medium-range transport curve for the upstream basin indicates the TN concentration for both upstream and downstream runoff would equal or exceed about $1.24 \mathrm{mg} / \mathrm{L}$ for the risk of exceedances corresponding to 50 percent of the storm events, without or with bioretention BMP treatment (table 22). At the 1-in-3 year risk of exceedance threshold ( 0.61 percent of storm events), the simulated EMC for the upstream and downstream runoff would equal or exceed $4.54 \mathrm{mg} / \mathrm{L}$ (table 22).

SELDM outputs generated from the water-quality simulations include a series of annual highway-runoff volumes and loads, which are the product of stochastically generated random runoff concentrations and flows (Granato, 2013). As part of the simulations, SELDM generates a 30-year record of the annual total runoff volumes and loads. In simulations used to evaluate a BMP treatment, the output of annual values can allow comparisons of the highway-runoff volumes normalized by the drainage area of the highway catchment. The highwaycatchment drainage area can also be used to prorate the annual loads to annual load yields (per acre of drainage area).

For the TN simulations (and those for TP discussed in the subsequent section), the series of annual highway-runoff volumes were normalized by the highway-catchment drainage area (10 acres), and an average annual total flow was determined for highway runoff without BMP treatment (31.2 in.), as well as post grass swale (21.6 in.) and 
bioretention (13.2 in.) BMP treatments (fig. 25). Comparisons of the average annual total flows indicate that the grass swale BMP results in a 30.8-percent flow reduction, and the bioretention BMP results in a 57.7-percent flow reduction. Prorating the average annual TN loads by the highwaycatchment drainage area results in average annual load yields of 7.4, 4.5, and 1.7 pounds for the highway without BMP treatment, grass swale BMP treatment, and bioretention BMP treatment, respectively (fig. 26). Comparisons of the average annual load yields indicate that the grass swale BMP results in a 39.2-percent annual load reduction per acre of highway catchment, and the bioretention BMP results in a 77.0-percent reduction. Although the TN loads for the highway runoff were reduced by the above noted percentages, the SELDM simulations indicate that the changes in downstream water quality are negligible because the upstream $\mathrm{TN}$ concentration dominates the conditions in the downstream reach below the highway crossing. This observation likely reflects the highway-catchment drainage area (10 acres) being a very small fraction of the $25-\mathrm{mi}^{2}$ upstream basin ( 0.06 percent).
Although average annual yields with and without the BMP treatments are shown (figs. 25 and 26), it should be noted these values represent results of stochastic simulations for each runoff event, not application of average performance statistics for the entire simulation period. Individually, both flow reduction and concentration reduction have a substantial effect on the annual yields of the constituents in these simulations. However, the BMPs can produce excess flows and concentrations in some storms, which can reduce or eliminate the combined effectiveness of BMP treatment following the storms. For example, if concentrations are reduced in a given storm but the discharge flow is larger than the runoff inflow, then the total BMP discharge load may be greater than or equal to the highway-runoff load. Increases in flow can be caused by carryover from previous storms or groundwater discharge to the BMP (especially for wet BMPs). Resuspension of previously deposited constituents can cause increases in discharge concentrations.

Table 21. Simulated total nitrogen concentrations equaled or exceeded in the highway runoff, upstream stormflow, and downstream stormflow for selected percentages of storm events, without and with a grass swale best management practice (BMP) applied to the highway-runoff component.

[Simulations of upstream runoff were varied to reflect low (good), medium, and high (poor) water-quality conditions, as reflected in selected water-quality transport curves chosen to represent the potential ranges in concentrations. Water-quality concentrations are at or above indicated concentration for selected percentage of storm events. The 1-in-3 year risk is defined by the U.S. Environmental Protection Agency and represents the water-quality concentration that may be equaled or exceeded, on average, once in a 3-year period. See table 8 and figure 8 for information on selected transport curves. $\mathrm{mg} / \mathrm{L}$, milligram per liter; n/a, BMP not applied for simulation of constituent concentration]

\begin{tabular}{|c|c|c|c|c|c|c|c|}
\hline \multirow[b]{2}{*}{ Basin component } & \multirow{2}{*}{$\begin{array}{l}\text { Without } \\
\text { or with } \\
\text { BMP }\end{array}$} & \multicolumn{6}{|c|}{$\begin{array}{l}\text { Simulated suspended sediment concentration equaled or exceeded } \\
\text { for indicated percentage of storm events, in } \mathrm{mg} / \mathrm{L}\end{array}$} \\
\hline & & $\begin{array}{l}0.04 \text { percent } \\
\text { (minimum) }\end{array}$ & 25 percent & 50 percent & 75 percent & $\begin{array}{l}99.96 \text { percent } \\
\text { (maximum) }\end{array}$ & $\begin{array}{c}0.61 \text { percent } \\
\text { (1-in-3 year } \\
\text { risk) }\end{array}$ \\
\hline \multirow[t]{2}{*}{ Highway runoff } & Without BMP & 4.88 & 1.29 & 0.92 & 0.64 & 0.14 & 3.43 \\
\hline & With BMP & 5.02 & 1.15 & 0.80 & 0.59 & 0.28 & 2.72 \\
\hline \multicolumn{8}{|c|}{ Upstream water quality simulated for low (good) water-quality conditions (using transport curve for site TC27) } \\
\hline Upstream stormflow & $\mathrm{n} / \mathrm{a}$ & 4.30 & 0.43 & 0.35 & 0.29 & 0.14 & 0.97 \\
\hline \multirow[t]{2}{*}{ Downstream stormflow } & Without BMP & 4.30 & 0.44 & 0.37 & 0.31 & 0.15 & 0.98 \\
\hline & With BMP & 4.30 & 0.43 & 0.36 & 0.29 & 0.14 & 0.98 \\
\hline \multicolumn{8}{|c|}{ Upstream water quality simulated for medium water-quality conditions (using transport curve for site TC24) } \\
\hline Upstream stormflow & $\mathrm{n} / \mathrm{a}$ & 6.04 & 1.66 & 1.21 & 0.88 & 0.24 & 4.34 \\
\hline \multirow[t]{2}{*}{ Downstream stormflow } & Without BMP & 6.04 & 1.65 & 1.20 & 0.88 & 0.25 & 4.29 \\
\hline & With BMP & 6.04 & 1.65 & 1.21 & 0.87 & 0.25 & 4.32 \\
\hline \multicolumn{8}{|c|}{ Upstream water quality simulated for high (poor) water-quality conditions (using transport curve for site TC6) } \\
\hline Upstream stormflow & $\mathrm{n} / \mathrm{a}$ & 51.7 & 11.8 & 7.61 & 4.69 & 1.16 & 39.5 \\
\hline \multirow[t]{2}{*}{ Downstream stormflow } & Without BMP & 44.1 & 11.5 & 7.53 & 4.63 & 1.16 & 34.9 \\
\hline & With BMP & 49.2 & 11.7 & 7.59 & 4.66 & 1.16 & 38.5 \\
\hline
\end{tabular}


Table 22. Simulated total nitrogen concentrations equaled or exceeded in the highway runoff, upstream stormflow, and downstream stormflow for selected percentages of storm events, without and with a bioretention best management practice (BMP) applied to the highway-runoff component.

[Simulations of upstream runoff were varied to reflect low (good), medium, and high (poor) water-quality conditions, as reflected in selected water-quality transport curves chosen to represent the potential ranges in concentrations. Water-quality concentrations are at or above indicated concentration for selected percentage of storm events. The 1-in-3 year risk is defined by the U.S. Environmental Protection Agency and represents the water-quality concentration that may be equaled or exceeded, on average, once in a 3-year period. See table 8 and figure 8 for information on selected transport curves. $\mathrm{mg} / \mathrm{L}$, milligram per liter; n/a, BMP not applied for simulation of constituent concentration]

\begin{tabular}{|c|c|c|c|c|c|c|c|}
\hline \multirow[b]{2}{*}{ Basin component } & \multirow{2}{*}{$\begin{array}{l}\text { Without } \\
\text { or with } \\
\text { BMP }\end{array}$} & \multicolumn{6}{|c|}{$\begin{array}{l}\text { Simulated suspended sediment concentration equaled or exceeded } \\
\text { for indicated percentage of storm events, in } \mathrm{mg} / \mathrm{L}\end{array}$} \\
\hline & & $\begin{array}{l}0.04 \text { percent } \\
\text { (minimum) }\end{array}$ & 25 percent & 50 percent & 75 percent & $\begin{array}{l}99.96 \text { percent } \\
\text { (maximum) }\end{array}$ & $\begin{array}{c}0.61 \text { percent } \\
\text { (1-in-3 year } \\
\text { risk) }\end{array}$ \\
\hline \multirow[t]{2}{*}{ Highway runoff } & Without BMP & 4.88 & 1.29 & 0.92 & 0.64 & 0.14 & 3.43 \\
\hline & With BMP & 2.90 & 0.73 & 0.52 & 0.37 & 0.17 & 1.59 \\
\hline \multicolumn{8}{|c|}{ Upstream water quality simulated for low (good) water-quality conditions (using transport curve for site TC27) } \\
\hline Upstream stormflow & $\mathrm{n} / \mathrm{a}$ & 2.40 & 0.44 & 0.36 & 0.30 & 0.13 & 0.99 \\
\hline \multirow[t]{2}{*}{ Downstream stormflow } & Without BMP & 2.40 & 0.46 & 0.38 & 0.32 & 0.14 & 0.99 \\
\hline & With BMP & 2.40 & 0.45 & 0.37 & 0.30 & 0.14 & 0.99 \\
\hline \multicolumn{8}{|c|}{ Upstream water quality simulated for medium water-quality conditions (using transport curve for site TC24) } \\
\hline Upstream stormflow & $\mathrm{n} / \mathrm{a}$ & 6.69 & 1.71 & 1.25 & 0.90 & 0.25 & 4.54 \\
\hline \multirow[t]{2}{*}{ Downstream stormflow } & Without BMP & 6.69 & 1.69 & 1.24 & 0.91 & 0.25 & 4.46 \\
\hline & With BMP & 6.69 & 1.69 & 1.24 & 0.90 & 0.25 & 4.48 \\
\hline \multicolumn{8}{|c|}{ Upstream water quality simulated for high (poor) water-quality conditions (using transport curve for site TC6) } \\
\hline Upstream stormflow & $\mathrm{n} / \mathrm{a}$ & 44.3 & 10.3 & 6.77 & 4.38 & 1.42 & 32.6 \\
\hline \multirow[t]{2}{*}{ Downstream stormflow } & Without BMP & 42.2 & 10.1 & 6.62 & 4.32 & 1.42 & 30.6 \\
\hline & With BMP & 44.1 & 10.2 & 6.69 & 4.36 & 1.42 & 32.3 \\
\hline
\end{tabular}




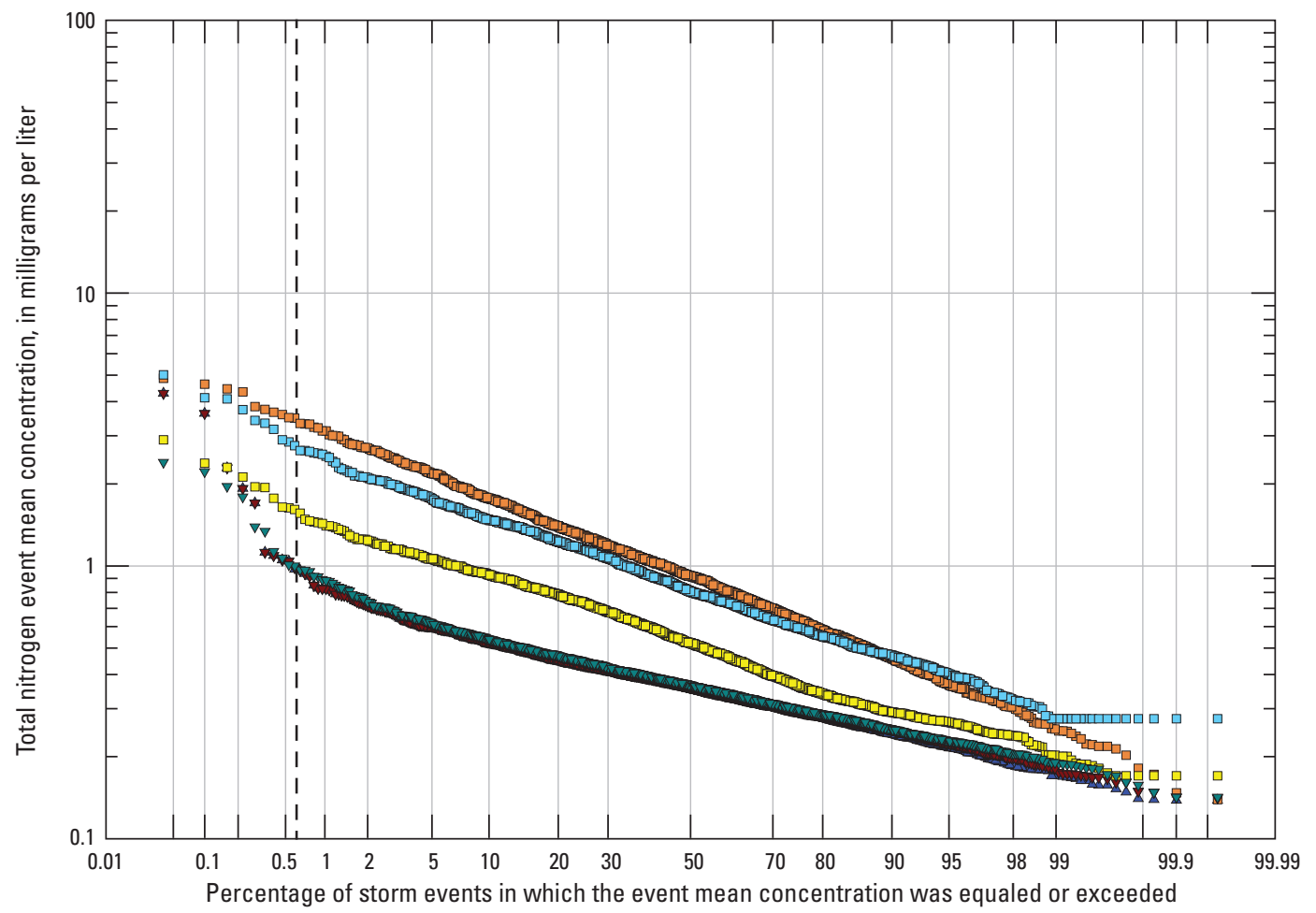

EXPLANATION

Percentage of storm events (0.61 percent) corresponding to a 1 -in-3 year risk of exceedance

$\Delta \quad$ Upstream event mean concentration

- Highway-runoff event mean concentration (without BMP)

$\square \quad$ Highway-runoff event mean concentration (post grass swale BMP)

$\square \quad$ Highway-runoff event mean concentration (post bioretention BMP)

- Fully mixed downstream event mean concentration (without BMP)

- Fully mixed downstream event mean concentration (post grass swale BMP)

$\nabla \quad$ Fully mixed downstream event mean concentration (post bioretention BMP)

Figure 22. Graph showing total nitrogen event mean concentrations in upstream flow, highway runoff, and downstream flow simulated for Piedmont rural creek (25-square-mile basin) by using the upstream transport curve for site TC27 (U.S. Geological Survey station 03460000), which represents the low range of potential total nitrogen concentrations from the upstream basin, without and with (post) best management practice (BMP) treatment. 


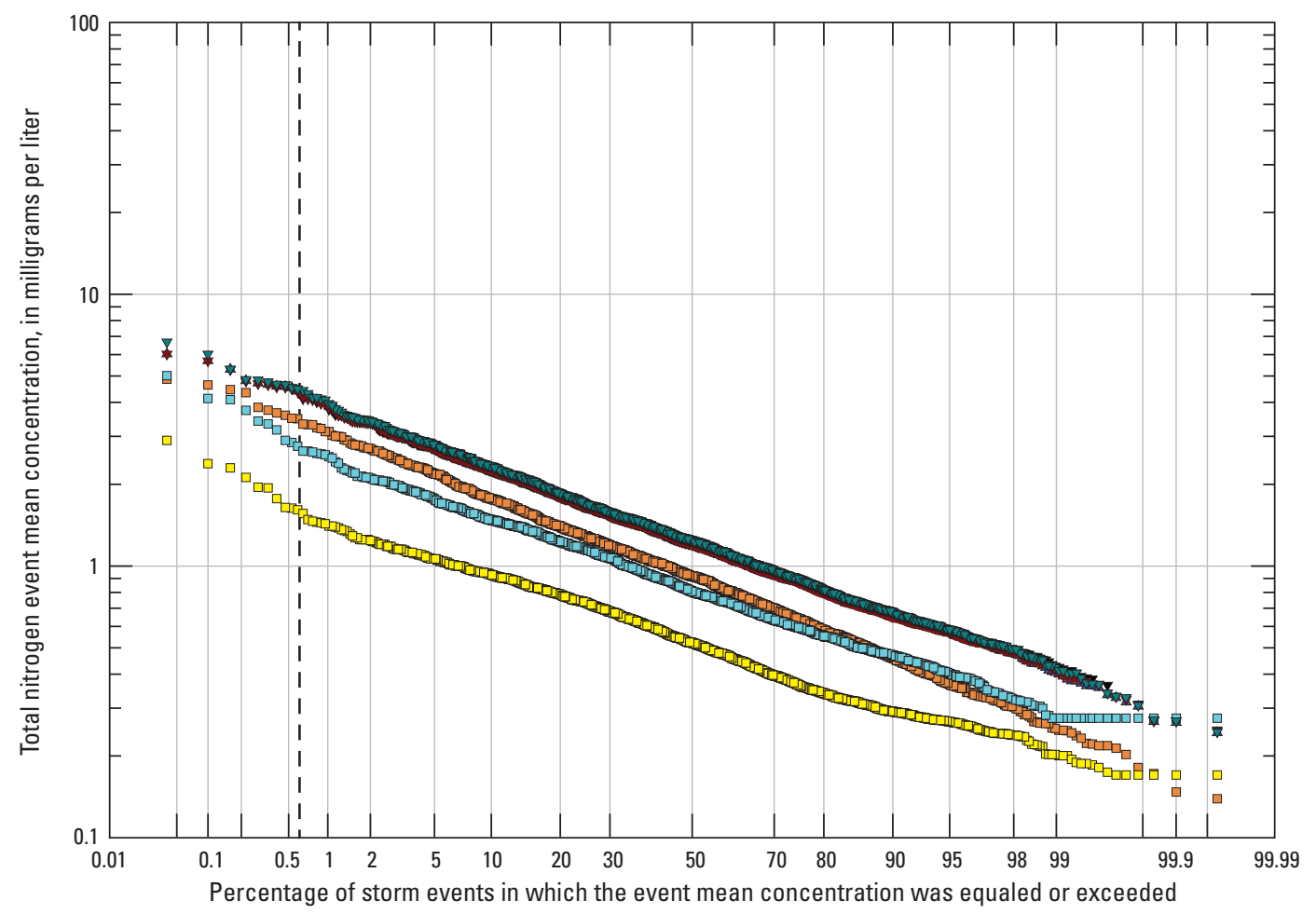

EXPLANATION

Percentage of storm events ( 0.61 percent) corresponding to a 1-in-3 year risk of exceedance

\ Upstream event mean concentration

․ Highway-runoff event mean concentration (without BMP)

$\square \quad$ Highway-runoff event mean concentration (post grass swale BMP)

$\square \quad$ Highway-runoff event mean concentration (post bioretention BMP)

v Fully mixed downstream event mean concentration (without BMP)

v Fully mixed downstream event mean concentration (post grass swale BMP)

$\nabla \quad$ Fully mixed downstream event mean concentration (post bioretention BMP)

Figure 23. Graph showing total nitrogen event mean concentrations in upstream flow, highway runoff, and downstream flow simulated for Piedmont rural creek (25-square-mile basin) by using the upstream transport curve for site TC24 (U.S. Geological Survey station 0214666925), which represents the medium range of potential total nitrogen concentrations from the upstream basin, without and with (post) best management practice (BMP) treatment. 


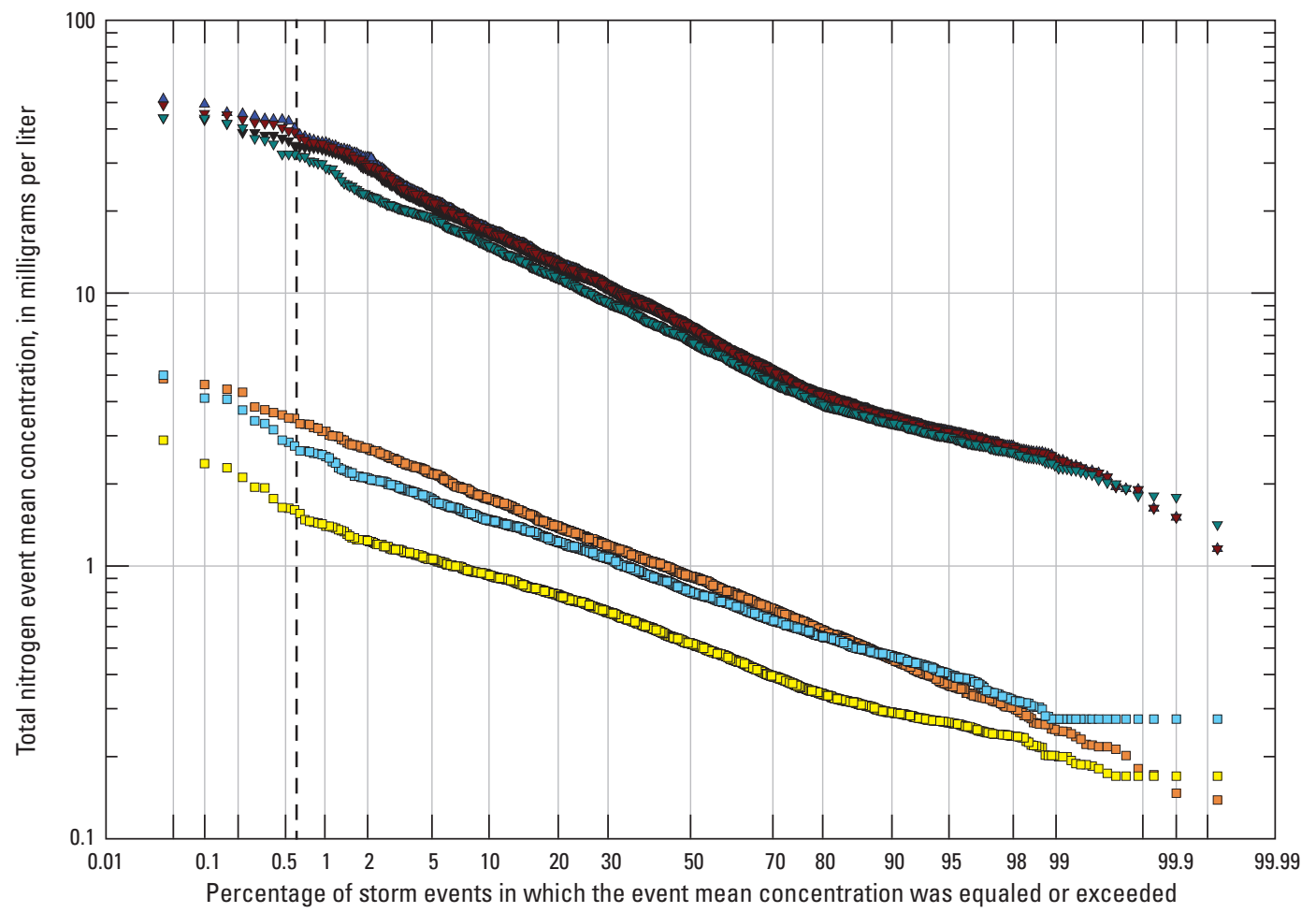

EXPLANATION

I Percentage of storm events ( 0.61 percent) corresponding to a 1 -in-3 year risk of exceedance

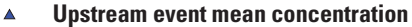

․ Highway-runoff event mean concentration (without BMP

․ Highway-runoff event mean concentration (post grass swale BMP)

Highway-runoff event mean concentration (post bioretention BMP)

v Fully mixed downstream event mean concentration (without BMP)

v Fully mixed downstream event mean concentration (post grass swale BMP)

$\nabla \quad$ Fully mixed downstream event mean concentration (post bioretention BMP)

Figure 24. Graph showing total nitrogen event mean concentrations in upstream flow, highway runoff, and downstream flow simulated for Piedmont rural creek (25-square-mile basin) by using the upstream transport curve for site TC6 (U.S. Geological Survey station 02086849), which represents the high range of potential total nitrogen concentrations from the upstream basin, without and with (post) best management practice (BMP) treatment. 


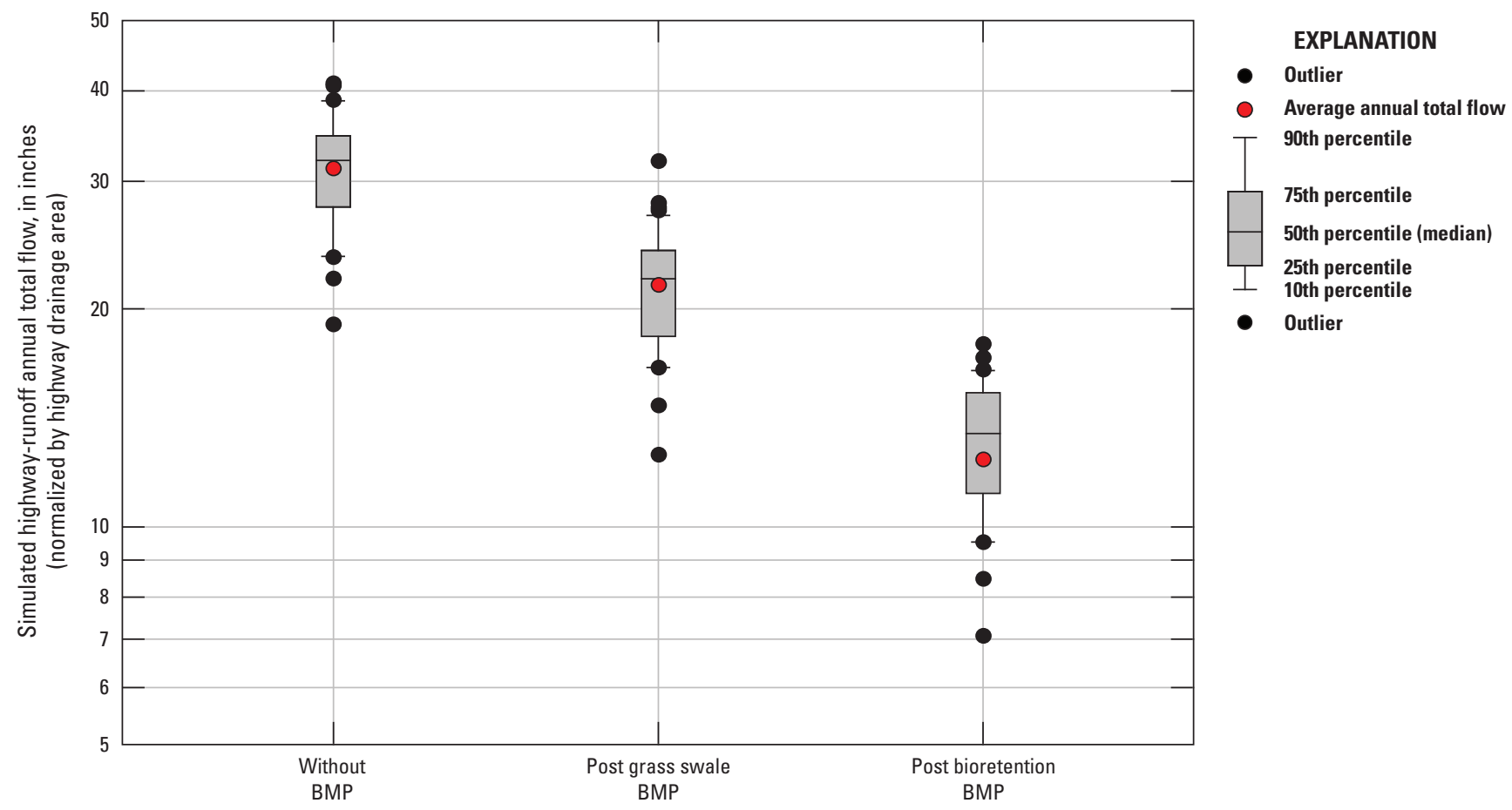

Figure 25. Boxplots showing ranges in simulated annual total flow for highway runoff without best management practice (BMP) treatment, with (post) grass swale BMP treatment, and with (post) bioretention BMP treatment.

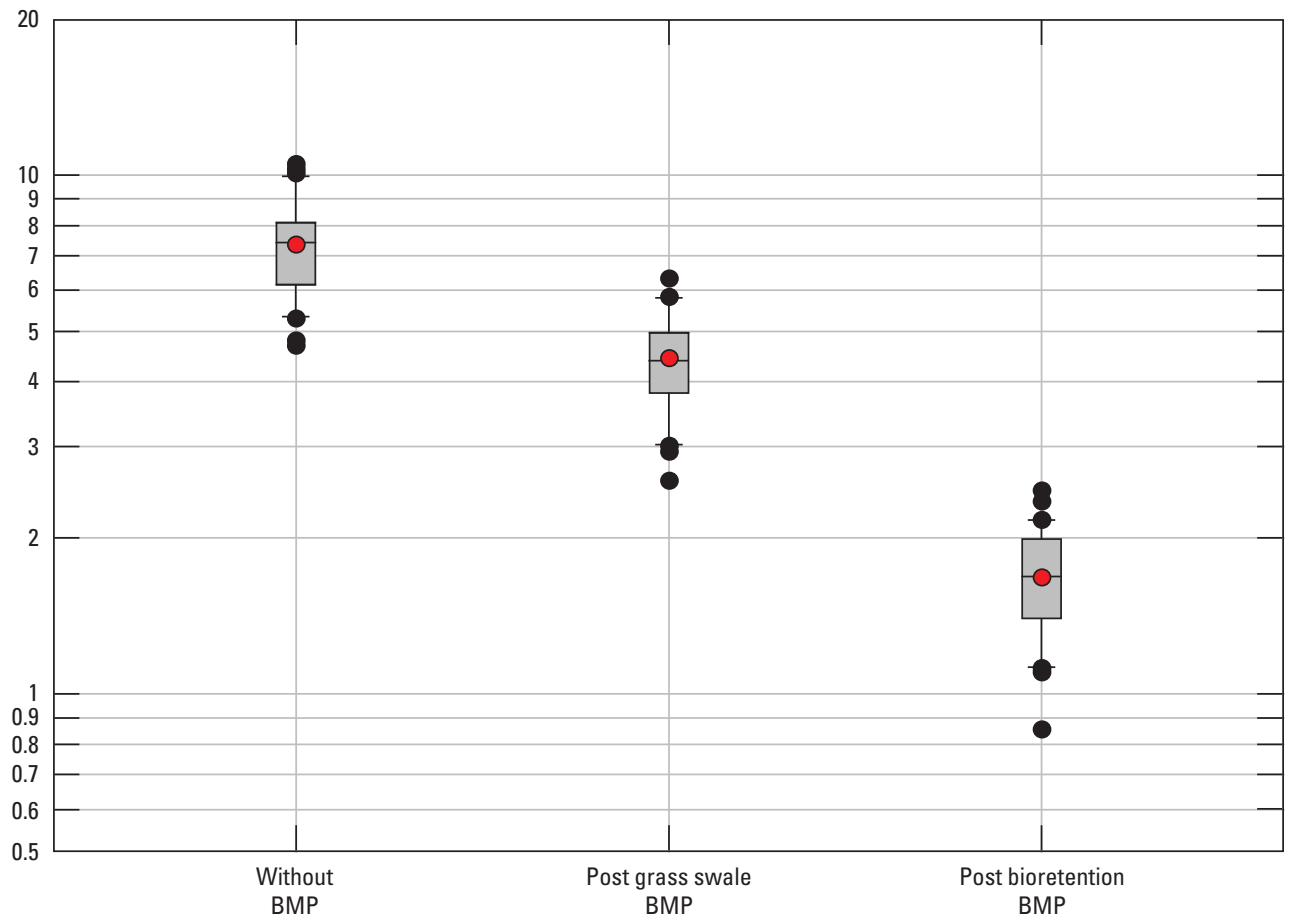

EXPLANATION

- Outlier

- Average annual load yield 90th percentile

75th percentile 50th percentile (median)

25th percentile

$\perp$ 10th percentile

- Outlier

Figure 26. Boxplots showing ranges in simulated total nitrogen annual load yield for highway runoff without best management practice (BMP) treatment, with (post) grass swale BMP treatment, and with (post) bioretention BMP treatment. 


\section{Varying Total Phosphorus}

Water-quality transport curves for sites TC4, TC15, and TC24 (table 8, fig. 8) were selected to simulate the low, medium, and high ranges, respectively, of TP EMCs for the upstream basin. The simulated concentrations are summarized for selected percentages of storm events in tables 23 and 24 and figs. 27-29.

TP concentrations simulated among the 1,633 storm events for the highway runoff equaled or exceeded $0.02 \mathrm{mg} / \mathrm{L}$ and $2.01 \mathrm{mg} / \mathrm{L}$ for risks of exceedances corresponding to 99.96 percent and 0.04 percent of storm events, respectively (table 23). The simulated highway-runoff TP EMCs without BMP treatment associated with the risks of exceedances corresponding to 25,50 , and 75 percent of storm events, equaled or exceeded $0.2 \mathrm{mg} / \mathrm{L}, 0.12 \mathrm{mg} / \mathrm{L}$, and $0.08 \mathrm{mg} / \mathrm{L}$, respectively. At the 1-in-3 year risk of exceedance threshold (0.61 percent of storm events), the simulated EMC equaled or exceeded $1.02 \mathrm{mg} / \mathrm{L}$. Expressed another way, there is a one-in-three chance that for any given year the TP EMC for the highway runoff without BMP treatment would be about $1.0 \mathrm{mg} / \mathrm{L}$ or higher.

With the application of a grass swale BMP treatment, the TP EMCs for the highway runoff equaled or exceeded 0.06 and $1.79 \mathrm{mg} / \mathrm{L}$ for risks of exceedances corresponding to 99.96 percent and 0.04 percent of storm events, respectively (table 23). For about 1 percent of the storm events (corresponding to 99 percent or higher on the horizontal axis; figs. 27-29), the TP EMC was equal to $0.06 \mathrm{mg} / \mathrm{L}$, a rounded variation of the North Carolina median MIC of $0.066 \mathrm{mg} / \mathrm{L}$ (table 15) determined in the grass swale BMP analyses completed for this study. Compared to the highway runoff without BMP treatment, use of the grass swale BMP treatment resulted in efficiency ratio values commonly ranging from about 0.7 to about 1.3. Expressed another way, the stochastic modeling using the BMP-performance statistics for grass swale in this simulation resulted in highway-runoff EMCs for TP ranging from 30 percent less to about 30 percent more than the concentrations without BMP treatment. The occurrence of equal or higher EMCs simulated by SELDM for TP following grass swale BMP treatment versus no BMP treatment for four of the six storm-event percentages $(0.61,50,75$, and 99.96 percent of storm events) listed in table 23 suggests a high degree of uncertainty in the reduction of concentrations.

Granato and Jones (2015) presented simulations of TP EMCs for highway runoff for a highway crossing over a tributary to the Flat River in northern Durham County, North Carolina (USGS sta. 0208650112), without BMP treatment and with grass swale, bioretention, and wetland basin BMP treatment. Simulated concentrations for the highway-runoff quality were based on sample statistics for an upstream bridge on Mountain Creek sampled by Wagner and others (2011), and BMP performance statistics from Granato (2014) were used to simulate the BMP-treated highway runoff. The EMCs for the upstream basin were based on use of a water-quality transport curve for Mountain Creek (USGS sta. 0208524090), the same site (TC4; table 8) used in these simulations to represent the low range of TP concentrations. Figure 27 indicates higher concentrations following grass swale BMP treatment for about 40 percent of storm events ( 60 percent or higher on the horizontal axis). This pattern echoes the simulated EMCs for treated highway runoff in Granato and Jones (2015, fig. 4, p. 14) that exceed untreated highway-runoff EMCs for 66 percent of the storm events.

Application of a bioretention BMP treatment did not indicate larger reductions in TP concentrations for highway runoff relative to either no BMP treatment or grass swale BMP treatment. Simulated TP EMCs for highway runoff after bioretention treatment equaled or exceeded 0.03 and $2.08 \mathrm{mg} / \mathrm{L}$ for risks of exceedances corresponding to 99.96 percent and 0.04 percent of storm events, respectively (table 24). For about 1 percent of the storm events (corresponding to 99 percent or higher on the horizontal axis; figs. 27-29), the TP EMC was equal to $0.03 \mathrm{mg} / \mathrm{L}$, a rounded variation of the North Carolina median MIC of $0.033 \mathrm{mg} / \mathrm{L}$ (table 15) determined in the bioretention BMP analyses completed for this study. Compared to the highway runoff without BMP treatment, use of the bioretention BMP treatment resulted in efficiency ratio values commonly ranging from about 0.68 to about 1.2. Alternately stated, the stochastic modeling using the BMP performance statistics for bioretention may result in a decrease in highway-runoff EMCs for TP from 32 percent less to about 20 percent more than the concentrations without BMP treatment, which is fairly comparable to the range of efficiency ratio values for highway-runoff concentrations subject to grass swale treatment. Similar to the simulation output for the grass swale BMP treatment, the EMCs for TP simulated by SELDM following bioretention BMP treatment are higher than the concentrations without BMP treatment for five of the six storm-event percentages (table 24). As with the grass swale BMP treatment, these comparisons likewise suggest a high degree of uncertainty in the reduction of concentrations using bioretention BMP treatment. This pattern echoes the simulated EMCs for bioretention-treated highway runoff in Granato and Jones (2015, fig. 4, p. 14) that exceed untreated highway runoff EMCs for 35 percent of the storm events.

As noted for TN, the TP simulations based on use of all three selected transport curves for the upstream basin do not suggest any meaningful differences between the upstream and downstream EMCs for the entire range in percentages of storms (tables 23 and 24, figs. 27-29). Upstream and downstream concentrations simulated using the high-range transport curve (site TC24) exceed the highway-runoff concentrations for all percentages of storm events (fig. 29).

Application of either the grass swale or bioretention BMP treatments to the highway runoff did not yield any reductions in TP concentrations downstream from the highway site (tables 23 and 24). As noted for the TN 
concentrations, the downstream TP concentrations were practically equal to the upstream concentrations when considering the potential uncertainties associated with outputs from the stochastic modeling combined with rounding of results. Use of the medium-range transport curve for the upstream basin indicates the TP concentration for both upstream and downstream runoff would equal or exceed $0.16 \mathrm{mg} / \mathrm{L}$ for 50 percent of the storms, without or with BMP treatment using a grass swale (table 23). At the 1-in-3 year risk of exceedance threshold ( 0.61 percent of storm events), the simulated EMC for the upstream and downstream runoff would equal or exceed $0.92 \mathrm{mg} / \mathrm{L}$ (table 23). When considering use of the bioretention treatment, these simulations likewise did not result in appreciable reductions between the upstream and downstream concentrations. Use of the medium-range transport curve for the upstream basin indicates the TP concentration for both upstream and downstream runoff would equal or exceed $0.16 \mathrm{mg} / \mathrm{L}$ for the risk of exceedance corresponding to 50 percent of the storm events, without or with bioretention BMP treatment (table 24). At the 1-in-3 year risk of exceedance threshold ( 0.61 percent of storm events), the simulated EMC for the upstream and downstream runoff would equal or exceed $1.07 \mathrm{mg} / \mathrm{L}$ (table 24).
Although the comparisons of total phosphorus concentrations for highway runoff without BMP treatment, with grass swale BMP treatment, and with bioretention BMP treatment suggest a high degree of uncertainty in the reduction of concentrations, comparisons of the average annual load yields suggest some benefit of these BMP treatments in reducing loads. Prorating the average annual TP loads by the highway-catchment drainage area (10 acres) results in average annual load yields of $1.2,0.82$, and 0.52 pounds for the highway without BMP treatment, with grass swale BMP treatment, and with bioretention BMP treatment, respectively (fig. 30). Comparisons of the average annual load yields indicate the swale BMP results in a 31.7-percent annual load reduction per acre of highway catchment, and the bioretention BMP results in a 56.7-percent reduction. As noted for TN, although the TP loads for the highway runoff were reduced by the above percentages, the SELDM simulations indicate the changes in downstream water quality are negligible because the upstream TP concentration dominates the conditions in the downstream reach below the highway crossing. Again, this observation likely reflects the highway-catchment drainage area (10 acres) being a very small fraction of the $25-\mathrm{mi}^{2}$ upstream basin $(0.06$ percent).

Table 23. Simulated total phosphorus concentrations equaled or exceeded in the highway runoff, upstream stormflow, and downstream stormflow for selected percentages of storm events, without and with a grass swale best management practice (BMP) applied to the highway-runoff component.

[Simulations of upstream runoff were varied to reflect low (good), medium, and high (poor) water-quality conditions, as reflected in selected water-quality transport curves chosen to represent the potential ranges in concentrations. Water-quality concentrations are at or above indicated concentration for selected percentage of storm events. The 1-in-3 year risk is defined by the U.S. Environmental Protection Agency and represents the water-quality concentration that may be equaled or exceeded, on average, once in a 3-year period. See table 8 and figure 8 for information on selected transport curves. mg/L, milligram per liter; n/a, BMP not applied for simulation of constituent concentration]

\begin{tabular}{|c|c|c|c|c|c|c|c|}
\hline \multirow[b]{2}{*}{ Basin component } & \multirow{2}{*}{$\begin{array}{l}\text { Without } \\
\text { or with } \\
\text { BMP }\end{array}$} & \multicolumn{6}{|c|}{$\begin{array}{l}\text { Simulated suspended sediment concentration equaled or exceeded } \\
\text { for indicated percentage of storm events, in } \mathrm{mg} / \mathrm{L}\end{array}$} \\
\hline & & $\begin{array}{l}0.04 \text { percent } \\
\text { (minimum) }\end{array}$ & 25 percent & 50 percent & 75 percent & $\begin{array}{l}99.96 \text { percent } \\
\text { (maximum) }\end{array}$ & $\begin{array}{c}0.61 \text { percent } \\
\text { (1-in-3 year } \\
\text { risk) }\end{array}$ \\
\hline \multirow[t]{2}{*}{ Highway runoff } & Without BMP & 2.01 & 0.20 & 0.12 & 0.08 & 0.02 & 1.02 \\
\hline & With BMP & 1.79 & 0.20 & 0.15 & 0.11 & 0.06 & 0.69 \\
\hline \multicolumn{8}{|c|}{ Upstream water quality simulated for low (good) water-quality conditions (using transport curve for site TC4) } \\
\hline Upstream stormflow & $\mathrm{n} / \mathrm{a}$ & 1.58 & 0.09 & 0.05 & 0.03 & 0.01 & 0.43 \\
\hline \multirow[t]{2}{*}{ Downstream stormflow } & Without BMP & 1.58 & 0.09 & 0.06 & 0.04 & 0.01 & 0.44 \\
\hline & With BMP & 1.58 & 0.09 & 0.06 & 0.04 & 0.01 & 0.43 \\
\hline \multicolumn{8}{|c|}{ Upstream water quality simulated for medium water-quality conditions (using transport curve for site TC15) } \\
\hline Upstream stormflow & $\mathrm{n} / \mathrm{a}$ & 1.34 & 0.25 & 0.16 & 0.11 & 0.02 & 0.93 \\
\hline \multirow[t]{2}{*}{ Downstream stormflow } & Without BMP & 1.34 & 0.25 & 0.17 & 0.11 & 0.02 & 0.92 \\
\hline & With BMP & 1.34 & 0.25 & 0.16 & 0.11 & 0.02 & 0.92 \\
\hline \multicolumn{8}{|c|}{ Upstream water quality simulated for high (poor) water-quality conditions (using transport curve for site TC24) } \\
\hline Upstream stormflow & $\mathrm{n} / \mathrm{a}$ & 13.2 & 0.63 & 0.43 & 0.29 & 0.07 & 2.69 \\
\hline \multirow[t]{2}{*}{ Downstream stormflow } & Without BMP & 13.2 & 0.63 & 0.43 & 0.29 & 0.06 & 2.69 \\
\hline & With BMP & 13.2 & 0.63 & 0.43 & 0.29 & 0.07 & 2.69 \\
\hline
\end{tabular}


Table 24. Simulated total phosphorus concentrations equaled or exceeded in the highway runoff, upstream stormflow, and downstream stormflow for selected percentages of storm events, without and with a bioretention best management practice (BMP) applied to the highway-runoff component.

[Simulations of upstream runoff were varied to reflect low (good), medium, and high (poor) water-quality conditions, as reflected in selected water-quality transport curves chosen to represent the potential ranges in concentrations. Water-quality concentrations are at or above indicated concentration for selected percentage of storm events. The 1-in-3 year risk is defined by the U.S. Environmental Protection Agency and represents the water-quality concentration that may be equaled or exceeded, on average, once in a 3-year period. See table 8 and figure 8 for information on selected transport curves. $\mathrm{mg} / \mathrm{L}$, milligram per liter; n/a, BMP not applied for simulation of constituent concentration]

\begin{tabular}{|c|c|c|c|c|c|c|c|}
\hline \multirow[b]{2}{*}{ Basin component } & \multirow{2}{*}{$\begin{array}{l}\text { Without } \\
\text { or with } \\
\text { BMP }\end{array}$} & \multicolumn{6}{|c|}{$\begin{array}{l}\text { Simulated suspended sediment concentration equaled or exceeded } \\
\text { for indicated percentage of storm events, in } \mathrm{mg} / \mathrm{L}\end{array}$} \\
\hline & & $\begin{array}{l}0.04 \text { percent } \\
\text { (minimum) }\end{array}$ & 25 percent & 50 percent & 75 percent & $\begin{array}{l}99.96 \text { percent } \\
\text { (maximum) }\end{array}$ & $\begin{array}{c}0.61 \text { percent } \\
\text { (1-in-3 year } \\
\text { risk) }\end{array}$ \\
\hline \multirow[t]{2}{*}{ Highway runoff } & Without BMP & 2.01 & 0.20 & 0.12 & 0.08 & 0.02 & 1.02 \\
\hline & With BMP & 2.08 & 0.24 & 0.15 & 0.09 & 0.03 & 0.69 \\
\hline \multicolumn{8}{|c|}{ Upstream water quality simulated for low (good) water-quality conditions (using transport curve for site TC4) } \\
\hline Upstream stormflow & $\mathrm{n} / \mathrm{a}$ & 1.58 & 0.10 & 0.06 & 0.04 & 0.01 & 0.47 \\
\hline \multirow[t]{2}{*}{ Downstream stormflow } & Without BMP & 1.58 & 0.11 & 0.06 & 0.04 & 0.01 & 0.47 \\
\hline & With BMP & 1.58 & 0.10 & 0.06 & 0.04 & 0.01 & 0.47 \\
\hline \multicolumn{8}{|c|}{ Upstream water quality simulated for medium water-quality conditions (using transport curve for site TC15) } \\
\hline Upstream stormflow & $\mathrm{n} / \mathrm{a}$ & 1.46 & 0.26 & 0.16 & 0.10 & 0.01 & 1.08 \\
\hline \multirow[t]{2}{*}{ Downstream stormflow } & Without BMP & 1.45 & 0.26 & 0.16 & 0.11 & 0.01 & 1.07 \\
\hline & With BMP & 1.45 & 0.26 & 0.17 & 0.11 & 0.01 & 1.08 \\
\hline \multicolumn{8}{|c|}{ Upstream water quality simulated for high (poor) water-quality conditions (using transport curve for site TC24) } \\
\hline Upstream stormflow & $\mathrm{n} / \mathrm{a}$ & 7.13 & 0.68 & 0.45 & 0.31 & 0.06 & 2.62 \\
\hline \multirow[t]{2}{*}{ Downstream stormflow } & Without BMP & 7.13 & 0.68 & 0.45 & 0.30 & 0.06 & 2.60 \\
\hline & With BMP & 7.13 & 0.68 & 0.45 & 0.31 & 0.07 & 2.62 \\
\hline
\end{tabular}




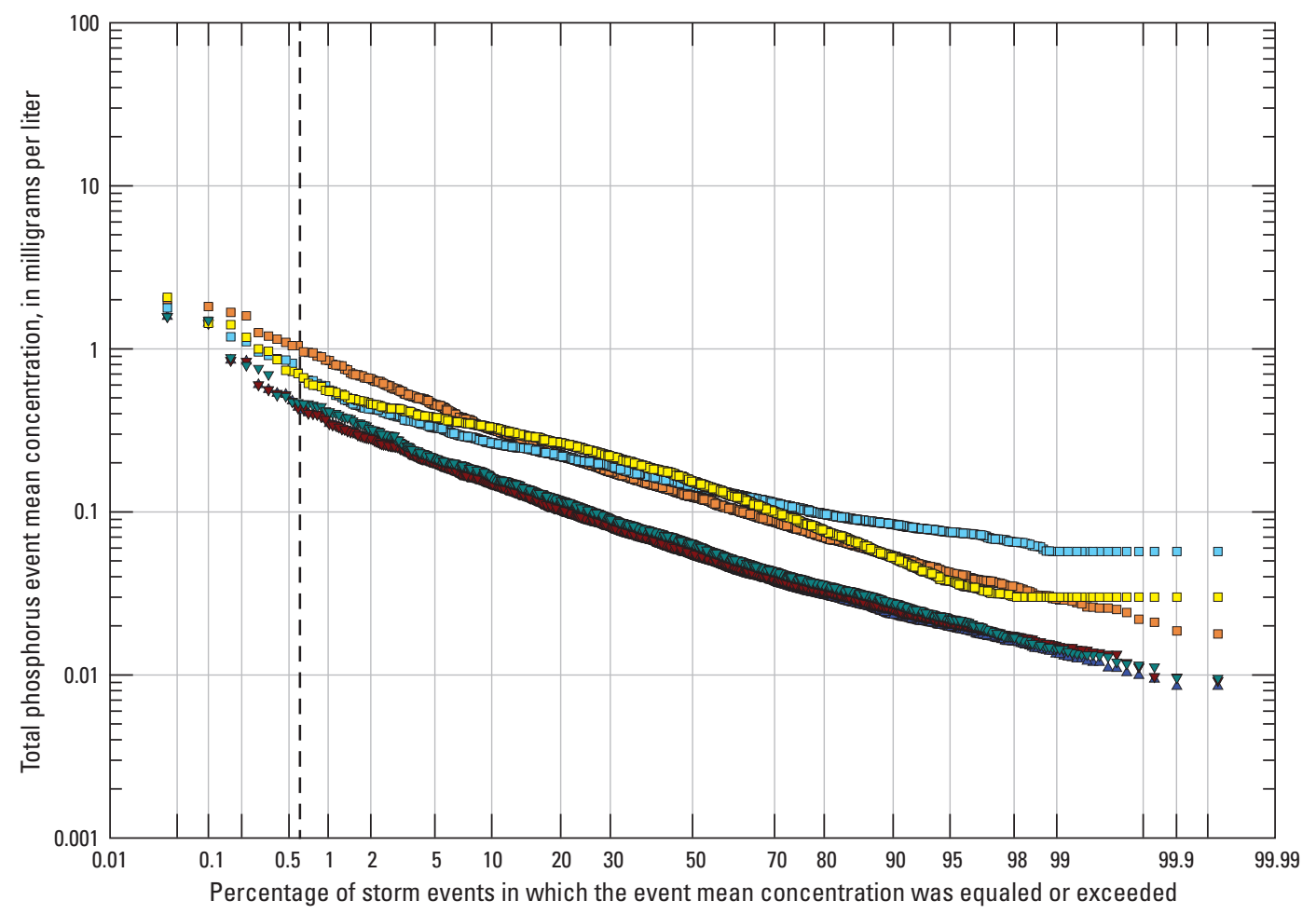

EXPLANATION

Percentage of storm events ( 0.61 percent) corresponding to a 1 -in-3 year risk of exceedance

$\Delta \quad$ Upstream event mean concentration

- Highway-runoff event mean concentration (without BMP)

- Highway-runoff event mean concentration (post grass swale BMP)

口 Highway-runoff event mean concentration (post bioretention BMP)

- Fully mixed downstream event mean concentration (without BMP)

v Fully mixed downstream event mean concentration (post grass swale BMP)

$\nabla \quad$ Fully mixed downstream event mean concentration (post bioretention BMP)

Figure 27. Graph showing total phosphorus event mean concentrations in upstream flow, highway runoff, and downstream flow simulated for Piedmont rural creek (25-square-mile basin) by using the upstream transport curve for site TC4 (U.S. Geological Survey station 0208524090), which represents the low range of potential total phosphorus concentrations from the upstream basin, without and with (post) best management practice (BMP) treatment. 


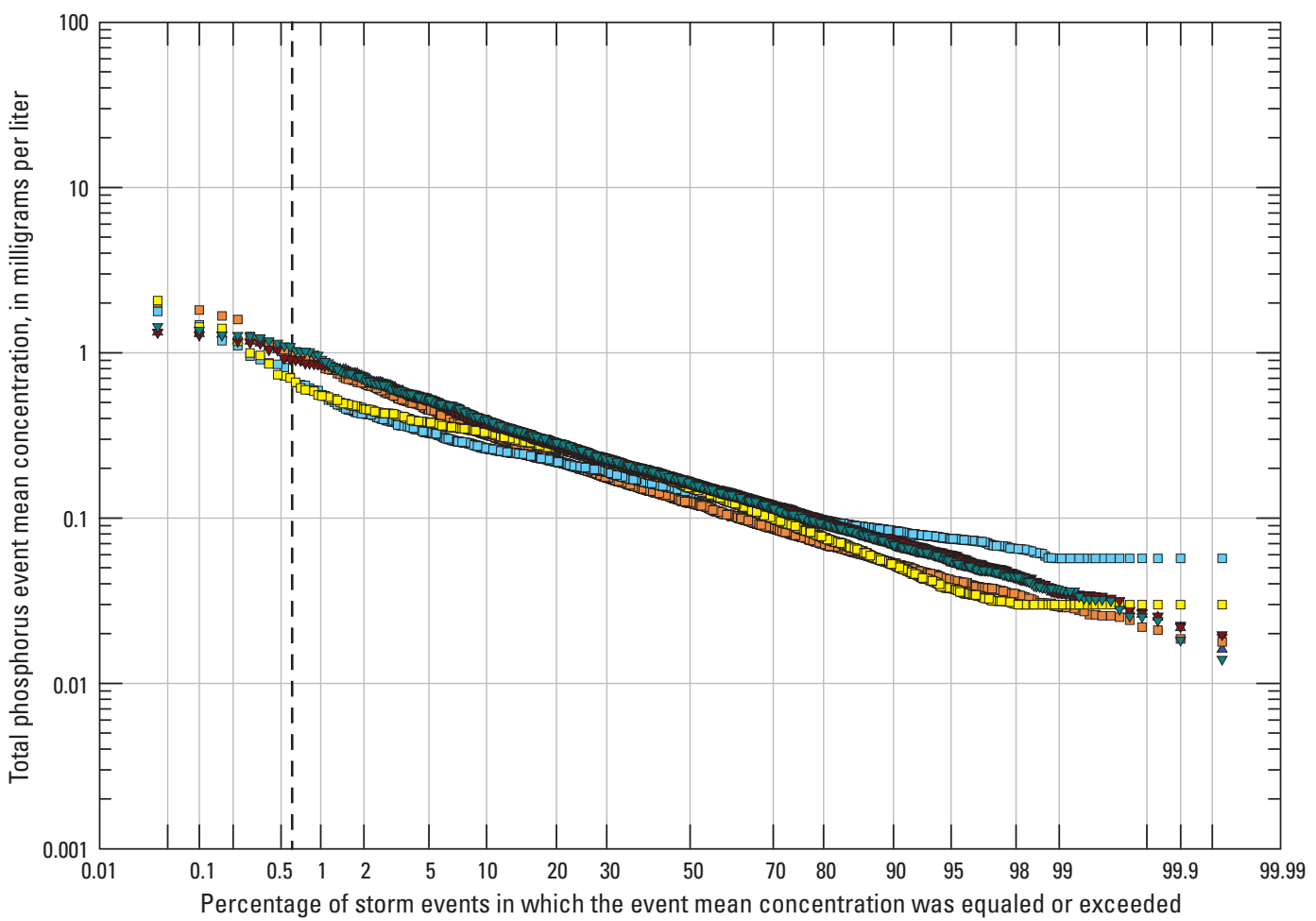

EXPLANATION

Percentage of storm events ( 0.61 percent) corresponding to a 1 -in-3 year risk of exceedance

4 Upstream event mean concentration

․ Highway-runoff event mean concentration (without BMP

$\square \quad$ Highway-runoff event mean concentration (post grass swale BMP)

$\square \quad$ Highway-runoff event mean concentration (post bioretention BMP)

v Fully mixed downstream event mean concentration (without BMP)

$\checkmark \quad$ Fully mixed downstream event mean concentration (post grass swale BMP)

$\nabla \quad$ Fully mixed downstream event mean concentration (post bioretention BMP)

Figure 28. Graph showing total phosphorus event mean concentrations in upstream flow, highway runoff, and downstream flow simulated for Piedmont rural creek (25-square-mile basin) by using the upstream transport curve for site TC15 (U.S. Geological Survey station 02097464), which represents the medium range of potential total phosphorus concentrations from the upstream basin, without and with (post) best management practice (BMP) treatment. 


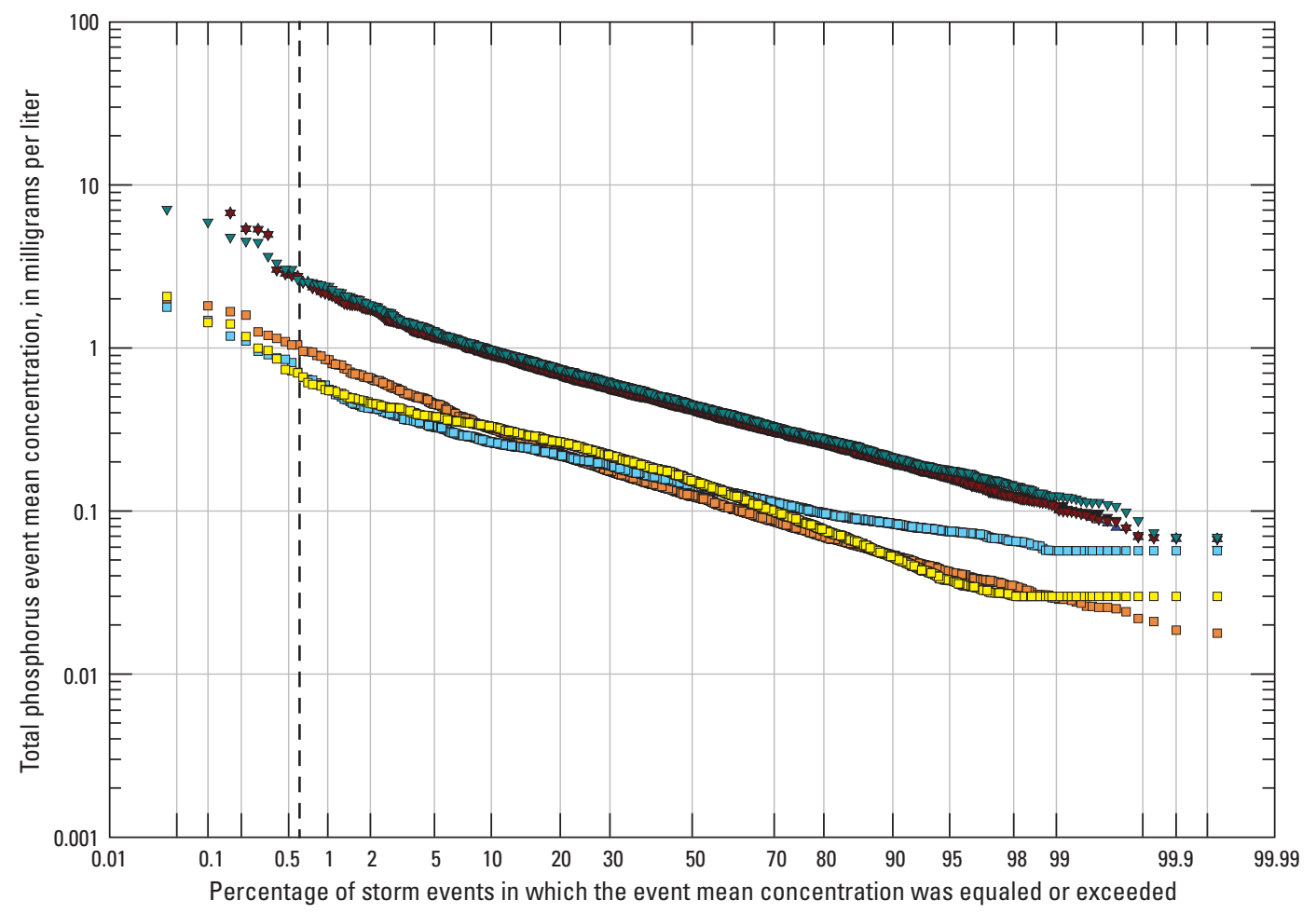

EXPLANATION

Percentage of storm events ( 0.61 percent) corresponding to a 1 -in-3 year risk of exceedance

$\Delta \quad$ Upstream event mean concentration

- Highway-runoff event mean concentration (without BMP)

- Highway-runoff event mean concentration (post grass swale BMP)

Highway-runoff event mean concentration (post bioretention BMP)

V Fully mixed downstream event mean concentration (without BMP)

v Fully mixed downstream event mean concentration (post grass swale BMP)

$\nabla \quad$ Fully mixed downstream event mean concentration (post bioretention BMP)

Figure 29. Graph showing total phosphorus event mean concentrations in upstream flow, highway runoff, and downstream flow simulated for Piedmont rural creek (25-square-mi basin) by using the upstream transport curve for site TC24 (U.S. Geological Survey station 0214666925), which represents the high range of potential total phosphorus concentrations from the upstream basin, without and with (post) best management practice (BMP) treatment. 


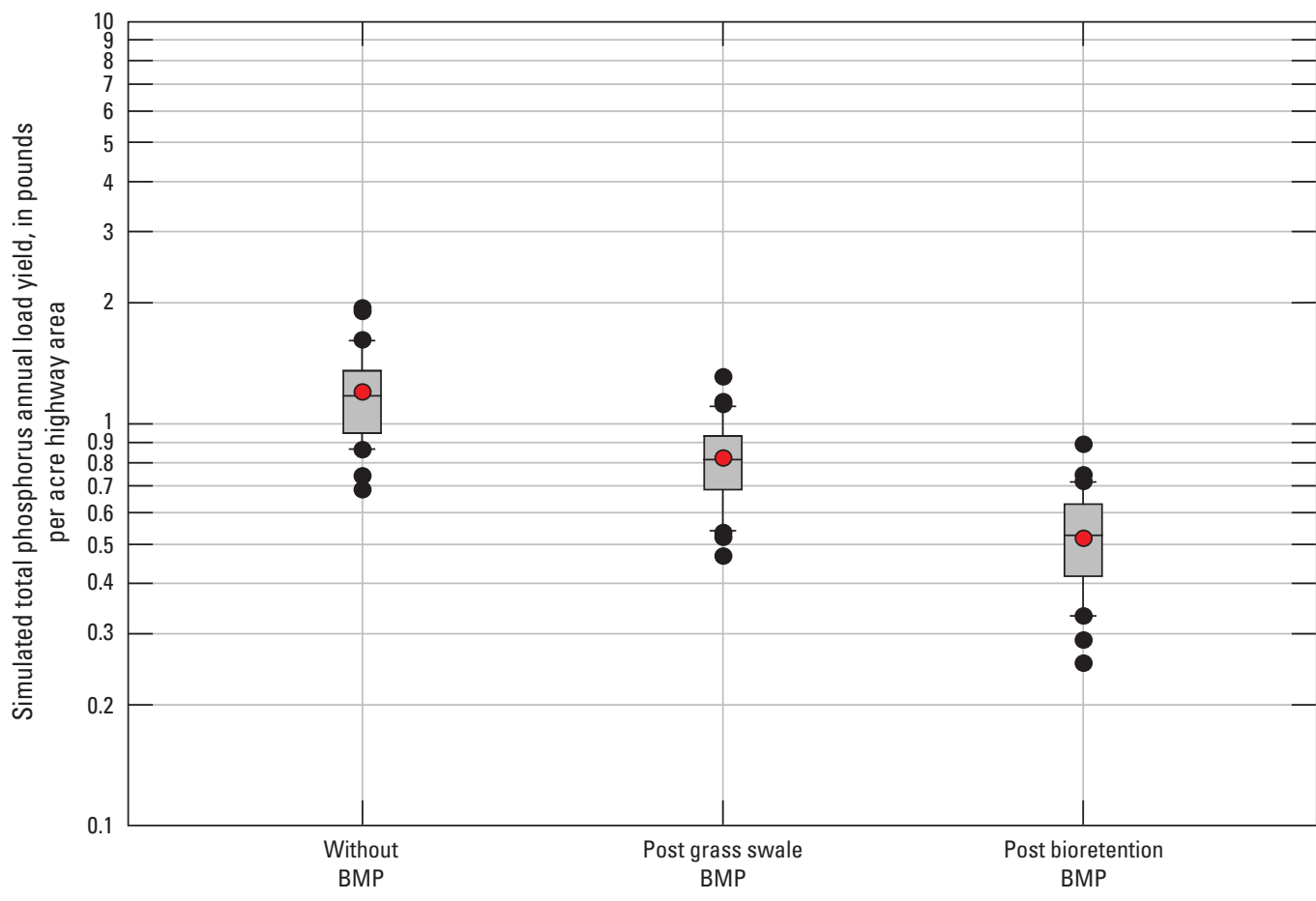

EXPLANATION

- Outlier

- Average annual load yield

T 90th percentile

75th percentile

50th percentile (median)

25th percentile

10th percentile

- Outlier

Figure 30. Boxplots showing ranges in simulated total phosphorus annual load yield for highway runoff without best management practice (BMP) treatment, with (post) grass swale BMP treatment, and with (post) bioretention BMP treatment. 


\section{Summary and Conclusions}

The North Carolina Department of Transportation (NCDOT) maintains approximately 80,000 miles of primary and secondary roads in North Carolina. Currently (2019), stormwater runoff from NCDOT property is managed under the provisions of the NCDOT's National Pollutant Discharge Elimination System permit issued by the North Carolina Department of Environmental Quality and the U.S. Environmental Protection Agency. The U.S. Geological Survey (USGS) in cooperation with the Federal Highway Administration (FHWA) developed the Stochastic Empirical Loading and Dilution Model (SELDM) to provide the tools and techniques necessary for performing stormwater-quality simulations. SELDM uses a stochastic mass-balance approach to estimate combinations of flows, concentrations, and loads of stormwater constituents from the site of interest, often a highway catchment, and the basin upstream from the stormwater outfall to assess the risk for adverse effects of runoff. SELDM also can be used to simulate the effectiveness of volume reduction, hydrograph extension, and water-quality concentration reductions by stormwater best management practices (BMPs), which are designed to help mitigate the effects of runoff on receiving water bodies.

To facilitate use nationwide, SELDM comes pre-loaded with selected statistics for many hydrologic and water-quality variables. The USGS partnered with the NCDOT to develop a North Carolina-enhanced variation of the national SELDM with available North Carolina-specific streamflow and waterquality data and to demonstrate use of the model by providing example simulations for selected scenarios. The addition of North Carolina-specific data to SELDM can help decision makers assess and mitigate potential effects of highway runoff on receiving waters in North Carolina.

SELDM uses precipitation statistics to stochastically simulate the number, volume, and duration of runoffgenerating events, which in turn are used with runoff coefficient statistics to generate the upstream-basin and the highway-catchment storm discharges. For the national SELDM, a total of 2,610 selected National Weather Service (NWS) hourly precipitation stations (of which 40 are in North Carolina) with period of record from 1965 to 2009 were used to compile storm-event characteristics into a national dataset. In the current study, a search was conducted to determine if any additional non-National Oceanic and Atmospheric Administration hourly precipitation stations in North Carolina with a minimum of 25 years of continuous data were available to supplement the national dataset. Two additional stations with 25 years of robust hourly precipitation data were identified within the State; however, the data were not readily converted to the data formats needed for the programs used to compile SELDM precipitation statistics. Therefore, the analysis of precipitation data was limited to the 40 sites within North Carolina and 52 additional NWS hourly precipitation stations in the surrounding States of Virginia, Tennessee, Georgia, and South Carolina. The
Parameter-elevation Regressions on Independent Slopes Model (PRISM) average annual precipitation dataset was adopted as a qualitative visual guide to help SELDM users identify areas of hydrologic similarity and select representative precipitation stations for a site of interest.

In SELDM, the prestorm flow is a primary component of the total upstream stormflow in many simulated events. As part of the current study, streamflow statistics for use with the North Carolina-enhanced SELDM were updated to include 266 selected continuous-record streamgages across North Carolina. Steps were taken to ensure the periods of record for the updated flow statistics were identical to those used in a recent USGS low-flow update for North Carolina streams but extended through the 2015 water year where data were available. This group of streamgages includes 177 unregulated sites, 56 regulated sites, and 33 sites known or considered to be affected by varying degrees of minor regulation and (or) diversions upstream from the streamgages.

SELDM uses hydrograph recession ratios along with basin lagtimes to simulate the timing of flow from the highway site and the upstream basin by using a triangular hydrograph. In this North Carolina study, the optimization methods were used to fit hydrographs to the triangular distribution for 30 basins with drainage areas ranging from 4.12 to 63.3 square miles $\left(\mathrm{mi}^{2}\right)$ and impervious percentages ranging from 0.01 to 48.8 percent. The hydrograph statistics were calculated by using 22 or more selected storm-event (runoff) hydrographs from each of the basins. The minimum, most probable value, and maximum recession ratio values were estimated for each of the 30 streamgages. The North Carolina-specific data had smaller average recession ratio statistics relative to the national statistics, which is considered reflective of the overall smaller range in drainage areas of the North Carolina streamgages. Additionally, given the urban characteristic in 11 of the 30 basins included in the North Carolina-specific data, the basins may have minimal storage, with runoff typically receding in a short amount of time, particularly relative to larger basins.

SELDM simulates stormflow water quality from the highway site and in the receiving water upstream from the highway-site discharge stochastically and then uses massbalance methods to calculate downstream concentrations and loads from paired highway and upstream values. The NCDOT identified previous research reports on highway runoff and BMP studies in North Carolina. As part of the current study, the USGS reviewed the integrity of the sites and data to determine whether the data were suitable for addition to the national FHWA Highway-Runoff Database (HRDB). A total of 25,087 event mean concentration (EMC) values and 1,140 storm events for 39 highway-runoff sites and 195 analytes were uploaded to the national HRDB from six North Carolina highway-runoff research reports and a recent USGS bridge deck runoff study.

Upstream water quality was simulated in this study by using the water-quality transport-curve option in SELDM. The transport-curve option was developed for use in SELDM because concentrations of many constituents commonly vary 
due to washoff and dilution processes in receiving waters. For the North Carolina study, a total of 57 water-quality transport curves were developed for six water-quality constituents (suspended sediment concentration, total nitrogen, total phosphorus, copper, lead, and zinc) and turbidity across 27 streamgages in North Carolina by using data through the 2016 water year retrieved from the USGS National Water Information System. Of the 27 streamgages, 20 are within the Piedmont ecoregion, 2 are within the Blue Ridge ecoregion, 4 are within the Southeastern Plains ecoregion, and 1 is within the Middle Atlantic Coastal Plain ecoregion. Drainage areas for the 27 streamgages range from $0.266 \mathrm{mi}^{2}$ to $2,692 \mathrm{mi}^{2}$, and 23 of the streamgages have drainage areas less than $80 \mathrm{mi}^{2}$. Selection of streamgages for analyses and development of the curves reflected attempts to provide curves in each ecoregion with emphasis on streamgages considered rural or urban, those located downstream from a wastewater treatment plant, or those with substantial forested or agricultural land cover.

SELDM simulates highway-runoff treatment stochastically by using statistics for flow reduction, hydrograph extension, and concentration reduction by structural stormwater control measure BMPs. Performance data for three BMP devices from NCDOT research data were incorporated into the North Carolina-enhanced SELDM for statistics related to volume-reduction (grass strip or swale) and removal efficiency of four water-quality constituents and turbidity (grass strip or swale, bioretention, and(or) wetland channel). The four constituents included were total suspended solids, total nitrogen, total phosphorus, and nitrate plus nitrite. An analysis of BMP performance of the North Carolinaspecific data relative to the national BMP dataset was conducted. Overall, most of the North Carolina-specific BMP statistics were within the 95-percent uncertainty limits of the national BMP data with the exception of nitrate plus nitrite, for which all median statistics were outside the 95 -percent confidence intervals. As part of the North Carolina BMP analyses, the minimum irreducible concentrations (MICs) were determined for the four constituents. SELDM substitutes the MIC for BMP effluent concentrations that are less than the MIC for a given constituent.

Simulations using the North Carolina-enhanced SELDM are presented to demonstrate ways that simulations can be used to provide risk-based information about potential effects of stormwater runoff on downstream water quality and the potential for mitigating those risks by using BMPs. In the current study, two Piedmont hypothetical basins (rural and urban) were used to demonstrate the ranges in the simulated outputs (with and without BMP treatment) based on varying hydrologic and water-quality inputs while holding selected upstream-basin characteristics at constant values. A hypothetical highway site with a drainage area of 10 acres, drainage length of 3,025 feet, drainage slope of 50 feet per mile, and impervious area of 100 percent (all pavement) was used in all simulations.

The first group of simulations was completed to explore the stochastic variability in dilution factors for the hypothetical rural basin with varying drainage areas. The dilution factor, which ranges from 0 to 1 , is the ratio of the highway runoff to the total downstream stormflow. A total of 14 simulations were completed using the North Carolina-enhanced SELDM for the hypothetical highway crossing over the Piedmont rural creek with drainage areas of $1,5,10,25,50,75$, and $100 \mathrm{mi}^{2}$. The dilution factors in these simulations decrease with increasing upstream areas because there is more prestorm flow and runoff for dilution with increasing area.

The second group of simulations completed for this report examined the dilution factors based on variations in precipitation, streamflow, and recession ratios. These simulations were completed for two Piedmont upstream basins where the drainage area was held constant at $25 \mathrm{mi}^{2}$. The first basin is a rural basin with the impervious area set at 2 percent, and the second is an urban basin with the impervious area set at 20 percent. A total of 36 simulations were completed for this group, three sets of 12 simulations that varied precipitation, streamflow, or recession ratios while holding the other two variables constant. In all simulations for the second group, the risks of exceeding the selected dilution-factor threshold (0.1) were lower for the urban basin relative to the rural basin, with or without BMP treatment. Among variations in precipitation, average discharge (from the upstream basin), and most probable value recession ratios, the most substantial differences in the simulated dilution factors occurred as a result of variation between the minimum, average, and maximum average discharge.

The third group of simulations examined the effects of varied concentrations in the upstream basin on water-quality conditions downstream from the highway crossing. Variations in upstream water-quality conditions for three constituents (suspended sediment concentration [SSC], total nitrogen [TN], and total phosphorus [TP]) were simulated by using waterquality transport curves selected from among the 57 curves developed as part of this study to represent low-, medium-, and high-concentration statistics. All simulations completed as part of this group were applied to the Piedmont rural creek (impervious area 2 percent) demonstration site with a drainage area of $25 \mathrm{mi}^{2}$ and mean channel slope of 19 feet/mile. A total of 21 simulations were generated for the third group. For SSC, a set of three simulations was completed, one for each of the three selected transport curves (low, medium, and high; no BMP statistics were applied for the SSC simulations). For TN and TP, a set of nine simulations was completed for each constituent, one for each of the three selected curves without BMP, with the grass swale BMP, and with the bioretention BMP.

The simulations for SSC suggest the presence of the highway-catchment area will potentially increase downstream water-quality concentrations for about 30 percent or less of storm events, based on the upstream-basin concentrations simulated using the low-range water-quality transport curve for SSC. Simulations based on use of the medium- and high-range water-quality transport curves for the upstream basin do not suggest any meaningful differences between the upstream and downstream suspended sediment EMCs for the 
entire range in percentages of storms. None of the TN or TP simulations based on use of all three selected transport curves for the upstream basin suggest any meaningful differences between the upstream and downstream EMCs for the entire range in percentages of storms, with or without BMPs. Upstream and downstream concentrations simulated for these two constituents using the high-range transport curves exceed the highway-runoff concentrations for all percentages of storm events. Comparison of normalized average annual highway runoff for the TN and TP simulations indicate that the grass swale BMP results in a 31.7-percent flow reduction and the bioretention BMP results in a 56.7-percent flow reduction. Comparisons of the average annual load yields for $\mathrm{TN}$ indicate that 39.2-percent and 77.0-percent annual load reduction per acre of highway catchment using the grass swale and bioretention BMP treatments, respectively. Comparisons of the average annual load yields for TP indicate 31.7-percent and 56.7percent annual load reduction per acre of highway catchment using the grass swale and bioretention BMP treatments, respectively.

The stochastic mass-balance approach used in SELDM analyses and simulations provides a strong tool for NCDOT engineers and water-resource managers to use in exploring a wide range of possible hydrologic and water-quality inputs and their effects on downstream water quality. The results of this study can not only aid engineers and managers in planning for potential adverse effects at site-specific locations, but they can also help the USGS and other Federal and State agencies with oversight responsibilities in stormwater-quality issues to continue gathering data on potential water-quality effects in receiving streams. These results may also lead to the identification of better methods (either via adjustments to the current SELDM application or identification of new methods) that can improve scientific understanding of potential water-quality effects and (or) regulatory oversight of such effects.

\section{References Cited}

American Association of State Highway and Transportation Officials, 2011, A policy on geometric design of highways and streets (6th ed.): Washington, D.C., American Association of State Highway and Transportation Officials, $912 \mathrm{p}$.

Antweiler, R.C., and Taylor, H.E., 2008, Evaluation of statistical treatments of left-censored environmental data using coincident uncensored data sets-I. summary statistics: Environmental Science \& Technology, v. 42 , no. 10 , p. $3732-37381$. [Also available at https://doi.org/10.1021/es071301c.]
Athayde, D.N., Shelley, P.E., Driscoll, E.D., Gaboury, D., and Boyd, G.B., 1983, Results of the nationwide urban runoff program-Volume I, final report: Washington, D.C., U.S. Environmental Protection Agency, 186 p. [Also available at https://www3.epa.gov/npdes/pubs/sw_nurp_ vol_1_finalreport.pdf.]

Barnwell, T.O., Jr., and Krenkel, P.A., 1982, Use of water quality models in management decision making: Water Science and Technology, v. 14, nos. 9-11, p. 1095-1107. [Also available at https://doi.org/10.2166/wst.1982.0145.]

Bent, G.C., Gray, J.R., Smith, K.P., and Glysson, G.D., 2001, A synopsis of technical issues for monitoring sediment in highway and urban runoff: U.S. Geological Survey Open File Report 00-497, 51 p. [Also available at https://doi.org/10.3133/ofr2000497.]

Bent, G.C., Gray, J.R., Smith, K.P., and Glysson, G.D., 2003, A synopsis of technical issues for monitoring sediment in highway and urban runoff, chap. 5 of Granato, G.E., Zenone, C., and Cazenas, P.A., eds., The national highway runoff data and methodology synthesis, volume 1Technical issues for monitoring highway runoff and urban stormwater: Federal Highway Administration Publication FHWA-EP-03-054, p. 111-163. [Also available at https://newengland.water.usgs.gov/dev/g1/Reports/ FHWA-EP03-054.pdf.]

Biesecker, J.E., and Leifeste, D.K., 1975, Water quality of hydrologic bench marks-An indicator of water quality in the natural environment: U.S. Geological Survey Circular 460-E, 21 p. [Also available at https://doi.org/10.3133/ cir460E.]

Charlotte-Mecklenburg Storm Water Services, 2013, Bioretention, chap. 4.1 of Charlotte-Mecklenburg BMP Design Manual: Charlotte, N.C., Charlotte-Mecklenburg Storm Water Services, p. 4.1.1-4.1.76, accessed March 6, 2019, at https://charlottenc.gov/StormWater/Regulations/ Documents/BMP/4_1_BioretentionJuly_1_2013.pdf.

Clark, S.E., and Siu, C.Y.S., 2008, Measuring solids concentration in stormwater runoff-Comparison of analytical methods: Environmental Science \& Technology, v. 42, no. 2, p. 511-516. [Also available at https://doi.org/10.1021/es070371g.]

Conlon, K.J., and Journey, C.A., 2008, Evaluation of four structural best management practices for highway runoff in Beaufort and Colleton Counties, South Carolina, 2005-2006: U.S. Geological Survey Scientific Investigations Report 2008-5150, $121 \mathrm{p}$. [Also available at https://doi.org/10.3133/sir20085150.] 
Coon, W.F., Hayhurst, B.A., Kappel, W.M., Eckhardt, D.A.V., and Szabo, C.O., 2009, Water-quality characterization of surface water in the Onondaga Lake basin, Onondaga County, New York, 2005-08: U.S. Geological Survey Scientific Investigations Report 2009-5246, 68 p. [Also available at https://doi.org/10.3133/sir20095246.]

Croghan, C.W., and Egeghy, P.P., 2003, Methods of dealing with values below the limit of detection using SAS, in Proceedings of the SouthEast SAS User Group, St. Petersburg, Fla., September 22-24: Cary, N.C., SouthEast SAS User Group, 5 p.

Di Toro, D.M., 1984, Probability model of stream quality due to runoff: Journal of Environmental Engineering, v. 110, no. 3, p. 607-628. [Also available at https://doi.org/10.1061/ (ASCE)0733-9372(1984)110:3(607).]

Driscoll, E.D., Palhegyi, G.E., Strecker, E.W., and Shelley, P.E., 1989, Analysis of storm event characteristics for selected rainfall gages throughout the United States: U.S. Environmental Protection Agency, prepared by Woodward-Clyde Consultants, Oakland, Calif., 43 p. [Also available at https://nepis.epa.gov/Exe/ZyPURL. cgi?Dockey=P100F7F7.TXT.]

Driscoll, E.D., Shelley, P.E., Gaboury, D.R., and Salhotra, A., 1989, A probabilistic methodology for analyzing water quality effects of urban runoff on rivers and streams: U.S. Environmental Protection Agency Report EPA 841-R89-101, 128 p. [Also available at https://nepis.epa.gov/ Exe/ZyPURL.cgi?Dockey=20004REH.TXT.]

Driscoll, E.D., Shelley, P.E., and Strecker, E.W., 1990, Pollutant loadings and impacts from highway stormwater runoff, Volume III-Analytical investigation and research report: Federal Highway Administration Final Report, FHWA-RD-88-008, 160 p.

Federal Emergency Management Agency, 2001, Discussion on USGS regression equations and the NFF ProgramUnusual parameters of USGS regression equations and how to obtain them-part 3: National Flood Frequency Bulletin, Issue No. 7, accessed April 28, 2012, at http:/www.floodmaps.fema.gov/listserv/nf_nov01.shtml.

Galloway, J.M., Evans, D.A., and Green, W.R., 2005, Comparability of suspended-sediment concentration and total suspended-solids data for two sites on the L'Anguille River, Arkansas, 2001 to 2003: U.S. Geological Survey Scientific Investigations Report 2005-5193, 10 p. [Also available at https://doi.org/10.3133/sir20055193.]

Glysson, G.D., 1987, Sediment-transport curves: U.S. Geological Survey Open-File Report 87-218, 47 p., [Also available at https://doi.org/10.3133/ofr87218.]
Granato, G.E., 2006, Kendall-Theil Robust Line (KTRLineversion 1.0) - A visual basic program for calculating and graphing robust nonparametric estimates of linearregression coefficients between two continuous variables: U.S. Geological Survey Techniques and Methods, book 4, chap. A7, 31 p. [Also available at https://doi.org/10.3133/ tm4A7.]

Granato, G.E., 2009, Computer programs for obtaining and analyzing daily mean streamflow data from the U.S. Geological Survey National Water Information System web site: U.S. Geological Survey Open-File Report 20081362, 123 p., 5 appendixes, CD-ROM. [Also available at https://doi.org/10.3133/ofr20081362.]

Granato, G.E., 2010, Methods for development of planninglevel estimates of stormflow at unmonitored stream sites in the conterminous United States: Federal Highway Administration, FHWA-HEP-09-005, 101 p., accessed March 7, 2019, via https://www.usgs.gov/centers/newengland-water/science/seldm-stochastic-empirical-loadingand-dilution-model-project-page.

Granato, G.E., 2012, Estimating basin lagtime and hydrograph-timing indexes used to characterize stormflows for runoff-quality analysis: U.S. Geological Survey Scientific Investigations Report 2012-5110, 47 p. [Also available at https://doi.org/10.3133/sir20125110.]

Granato, G.E., 2013, Stochastic empirical loading and dilution model (SELDM) version 1.0.0: U.S. Geological Survey Techniques and Methods, book 4, chap. C3, 112 p., CDROM. [Also available at https://doi.org/10.3133/tm4C3.]

Granato, G.E., 2014, Statistics for stochastic modeling of volume reduction, hydrograph extension, and water-quality treatment by structural stormwater runoff best management practices (BMPs): U.S. Geological Survey Scientific Investigations Report 2014-5037, 37 p. [Also available at https://doi.org/10.3133/sir20145037.]

Granato, 2016, SELDM-Stochastic Empirical Loading and Dilution Model: U.S. Geological Survey web page, accessed May 14, 2017, at https://doi.org/10.5066/ F7TT4P3G.

Granato, G.E., Bank, F.G., and Cazenas, P.A., 2003, Data quality objectives and criteria for basic information, acceptable uncertainty, and quality-assurance and qualitycontrol documentation, chap. 1 of Granato, G.E., Zenone, C., and Cazenas, P.A., eds., The national highway runoff data and methodology synthesis, v. I-Technical issues for monitoring highway runoff and urban stormwater: Federal Highway Administration Report FHWA-EP-03-054, p. 3-21. 
Granato, G.E., Carlson, C.S., and Sniderman, B.S., 2009, Methods for development of planning-level estimates of water quality at unmonitored sites in the conterminous United States: Federal Highway Administration, FHWA-HEP-09-003, 53 p.

Granato, G.E., and Cazenas, P.A., 2009, Highway-Runoff Database (HRDB Version 1.0) - A data warehouse and preprocessor for the stochastic empirical loading and dilution model: Federal Highway Administration, FHWA-HEP-09-004, 57 p.

Granato, G.E., Desmarais, K.L., Smith, K.P., Weaver, J.C., Glover-Cutter, K.M., Stonewall, A.J., and Fitzgerald, S.A., 2018, Highway-Runoff Database (HRDB) Version 1.0.0b: U.S. Geological Survey data release, accessed March 6, 2019, at https://doi.org/10.5066/P9YG44VQ.

Granato, G.E., and Jones, S.C., 2014, Stochastic Empirical Loading and Dilution Model for analysis of flows, concentrations, and loads of highway runoff constituents: Transportation Research Record-Journal of the Transportation Research Board, v. 2436, no. 1, p. 139-147. [Also available at https://doi.org/10.3141/2436-14.]

Granato, G.E., and Jones, S.C., 2015, Estimating the risks for adverse effects of total phosphorus in receiving streams with the Stochastic Empirical Loading and Dilution Model (SELDM), in Proceedings of the 2015 International Conference on Ecology and Transportation (ICOET 2015), September 20-24, 2015: Raleigh, N.C., North Carolina State University, Center for Transportation and the Environment, 18 p.

Granato, G.E., and Jones, S.C., 2017a, Estimating risks for water-quality exceedances of total-copper from highway and urban runoff under predevelopment and current conditions with the Stochastic Empirical Loading and Dilution Model (SELDM), in Dunn, C.N., and Van Weele, B., eds., World Environmental and Water Resources Congress 2017-Watershed management, irrigation and drainage, and water resources planning and management, Sacramento, Calif.: Reston, Va., American Society of Civil Engineers, 15 p. [Also available at https://doi.org/10.1061/9780784480601.028.]

Granato, G.E., and Jones, S.C., 2017b, Estimating total maximum daily loads with the Stochastic Empirical Loading and Dilution Model: Transportation Research Record-Journal of the Transportation Research Board, v. 2638, no. 1, p. 104-112. [Also available at https://doi.org/10.3141/2638-12.]
Granato, G.E., Ries, K.G., III, and Steeves, P.A., 2017, Compilation of streamflow statistics calculated from daily mean streamflow data collected during water years 19012015 for selected U.S. Geological Survey streamgages: U.S. Geological Survey Open-File Report 2017-1108, 17 p. [Also available at https://doi.org/10.3133/ofr20171108.]

Gray, J.R., Glysson, G.D., Turcios, L.M., and Schwarz, G.E., 2000, Comparability of suspended-sediment concentration and total suspended solids data: U.S. Geological Survey Water-Resources Investigations Report 2000-4191, 14 p. [Also available at https://doi.org/10.3133/wri004191.]

Griffith, G.E., Omernik, J.M., Comstock, J.A., Schafale, M.P., McNab, W.H., Lenat, D.R., MacPherson, T.F., Glover, J.B., and Shelburne, V.B., 2002, Ecoregions of North Carolina and South Carolina: Reston, Va., U.S. Geological Survey, poster with map, 2 sheets, scale 1:1,500,00.

Guo, J.C.Y., and MacKenzie, K., 2013, Detention basin volume estimating workbook version 2.32: Denver, Colo., Urban Drainage and Flood Control District, accessed August 4, 2013, at http://www.udfcd.org/.

Guo, Q.G., 2006, Correlation of total suspended solids (TSS) and suspended sediment concentration (SSC) test methods: Trenton, N.J., New Jersey Department of Environmental Protection, Division of Science, Research, and Technology, contract no. SR05-005, prepared by Rutgers University, New Brunswick, N.J., $52 \mathrm{p}$

Harmel, R.D., Cooper, R.J., Slade, R.M., Haney, R.L., and Arnold, J.G., 2006, Cumulative uncertainty in measured streamflow and water quality data for small watersheds: Transactions of the American Society of Agricultural and Biological Engineers, v. 49, no. 3, p. 689-701. [Also available at https://doi.org/10.13031/2013.20488.]

Helsel, D.R., and Hirsch, R.M., 2002, Statistical methods in water resources: U.S. Geological Survey Techniques of Water-Resources Investigations, book 4, chap. A3, 510 p. [Also available at https://doi.org/10.3133/twri04A3.]

Kacker, R.N., and Lawrence, J.F., 2007, Trapezoidal and triangular distributions for Type B evaluation of standard uncertainty: Metrologia, v. 44, no. 2, p. 117-127. [Also available at https://doi.org/10.1088/0026-1394/44/2/003.]

Landers, M.N., Ankcorn, P.D., and McFadden, K.W., 2007, Watershed effects on streamflow quantity and quality in six watersheds of Gwinnett County, Georgia: U.S. Geological Survey Scientific Investigations Report 2007-5132, 54 p. [Also available at https://doi.org/10.3133/sir20075132.]

Lech, W.Z., and Maryna, G., 2009, The best measurand estimators of trapezoidal PDF, in IMEKO World Congress, 19th, Lisbon, Portugal, 2009: Red Hook, N.Y., Curran Associates, Inc., p. 2405-2410. [Also available at http://www.imeko2009.it.pt/Papers/FP_513.pdf.] 
Line, D.E., 2006, Evaluating BMPs for treating stormwater and wastewater from NCDOT's highways, industrial facilities, and borrow pits: Raleigh, N.C., North Carolina State University, Final Report FHWA/NC/2006-05, [variously paged].

Luell, S.K., Winston, R.J., Wilson, C.E., Kennedy, S.G., and Hunt, W.F., 2012, Retrofitting with bioretention and a swale to treat bridge deck stormwater runoff: Raleigh, N.C., North Carolina State University, Final Report, North Carolina Department of Transportation Research Project 2011-12, 148 p.

Mansell, M., and Rollet, F., 2006, Water balance and the behaviour of different paving surfaces: Water and Environment Journal, v. 20, no. 1, p. 7-10. [Also available at https://doi.org/10.1111/j.1747-6593.2005.00015.x.]

Marsalek, J., 1991, Pollutant loads in urban stormwaterReview of methods for planning-level estimates: Water Resources Bulletin, v. 27, no. 2, p. 283-291. [Also available at https://doi.org/10.1111/j.1752-1688.1991.tb03133.x.]

Marsalek, J., and Ng, H.Y.F., 1989, Evaluation of pollution loadings from urban nonpoint sources-Methodology and applications: Journal of Great Lakes Research, v. 15, no. 3, p. 444-451. [Also available at https://doi.org/10.1016/ S0380-1330(89)71500-8.]

Masch, F.D., 1984, Hydrology: Federal Highway Administration Report FHWA-IP-84-015, 342 p.

McCuen, R.H., Johnson, P.A., and Ragan, R.M., 2002, Highway hydrology-Hydraulic design series number 2, 2 ed.: Washington, D.C., Federal Highway Administration Report FHWA-NHI-02-001 HDS-2, 424 p.

McGill, R., Tukey, J.W., and Larsen, W.A., 1978, Variations of box plots: The American Statistician, v. 32, no. 1, p. 12-16. [Also available at https://doi.org/10.1080/00031305.1978.1 0479236.]

McNett, J.K., Hunt, W.F., and Osborne, J.A., 2010, Establishing storm-water BMP evaluation metrics based upon ambient water quality associated with benthic macroinvertebrate populations: Journal of Environmental Engineering, v. 136, no. 5, p. 535 - 541, accessed March 6, 2019, at https://doi.org/10.1061/(ASCE)EE.1943-7870.0000185.

National Research Council, 2009, Urban stormwater management in the United States: Washington, D.C., The National Academies Press, 610 p. [Also available at https://doi.org/10.17226/12465.]

North Carolina Department of Transportation, undated a, Stormwater program-Frequently asked questions: North Carolina Department of Transportation web page, accessed July 13, 2017, at https://www.ncdot.gov/programs/ environment/stormwater/faq/.
North Carolina Department of Transportation, undated b, Stormwater program: North Carolina Department of Transportation web page, accessed July 13, 2017, at https://www.ncdot.gov/programs/environment/stormwater/.

Novotny, V., 2004, Simplified databased total maximum daily loads, or the world is log-normal: Journal of Environmental Engineering, v. 130, no. 6, p. 674-683. [Also available at https://doi.org/10.1061/(ASCE)07339372(2004)130:6(674).]

O'Connor, D.J., 1976, The concentration of dissolved solids and river flow: Water Resources Research, v. 12, no. 2, p. 279-294. [Also available at https://doi.org/10.1029/ WR012i002p00279.]

PRISM Climate Group, 2016, PRISM Climate Data: Corvallis, Oreg., Oregon State University, PRISM Climate Group web page, accessed July 15, 2016, at http://prism.oregonstate.edu.

Ramier, D., Berthier, E., Dangla, P., and Andrieu, H., 2006, Study of the water budget of streets - Experimentation and modeling: Water Science \& Technology, v. 54, nos. 6-7, p. 41-48. [Also available at https://doi.org/10.2166/ wst.2006.587.]

Ries, K.G., III, Guthrie, J.G., Rea, A.H., Steeves, P.A., and Stewart, D.W., 2008, StreamStats-A water resources web application: U.S. Geological Survey Fact Sheet 2008-3067, $6 \mathrm{p}$.

Risley, J.C., and Granato, G.E., 2014, Assessing potential effects of highway runoff on receiving-water quality at selected sites in Oregon with the Stochastic Empirical Loading and Dilution Model (SELDM): U.S. Geological Survey Scientific Investigations Report 2014-5099, 74 p. [Also available at https://doi.org/10.3133/sir20145099.]

Sauer, V.B., Thomas, W.O., Jr., Stricker, V.A., and Wilson, K.V., 1983, Flood characteristics of urban watersheds in the United States: U.S. Geological Survey Water-Supply Paper 2207, 63 p. [Also available at https://doi.org/10.3133/ wsp2207.]

Selbig, W.R., and Bannerman, R.T., 2011, Ratios of total suspended solids to suspended sediment concentrations by particle size: Journal of Environmental Engineering, v. 137 , no. 11 , p. 1075-1081. [Also available at https://doi.org/10.1061/(ASCE)EE.1943-7870.0000414.]

Smith, K.P., and Granato, G.E., 2010, Quality of stormwater runoff discharged from Massachusetts highways, 2005-07: U.S. Geological Survey Scientific Investigations Report 2009-5269, 198 p., CD-ROM. [Also available at https://doi.org/10.3133/sir20095269.] 
Smith, K.P., Sorenson, J.R., and Granato, G.E., 2018, Characterization of stormwater runoff from bridge decks in eastern Massachusetts, 2014-16: U.S. Geological Survey Scientific Investigations Report 2018-5033, 73 p. [Also available at https://doi.org/10.3133/sir20185033.]

Stonewall, A.J., Granato, G.E., and Haluska, T.L., 2018, Assessing roadway contributions to stormwater flows, concentrations, and loads with the StreamStats application: Transportation Research Record-Journal of the Transportation Research Board, 9 p. [Also available at https://doi.org/10.1177/0361198118758679.]

Stricker, V.A., and Sauer, V.B., 1982, Techniques for estimating flood hydrographs for ungaged urban watersheds: U.S. Geological Survey Open-File Report 82-365, 24 p. [Also available at https://doi.org/10.3133/ ofr82365.]

Taylor, S., Barrett, M., Leisenring, M., Sahu, S., Pankani, D., Poresky, A., Questad, A., Strecker, E., Weinstein, N., and Venner, M., 2014, Long-term performance and life-cycle costs of stormwater best management practices: National Cooperative Highway Research Program Report 792, 148 p. [Also available at http://www.trb.org/Publications/ Blurbs/171471.aspx.]

U.S. Environmental Protection Agency, 1986, Technical guidance manual for performing wasteload allocation, book VI, design conditions, chapter 1, stream design flow for steady-state modeling: U.S. Environmental Protection Agency, Publication 440/4-86-014, [variously paged].

U.S. Environmental Protection Agency, 2003, Level III ecoregions of the continental United States: Corvallis, Oreg., U.S. Environmental Protection Agency, National Health and Environmental Effects Research Laboratory, 1 pl., scale 1:7,500,000, accessed July 16, 2018, at https://www.epa.gov/eco-research/ecoregions.

U.S. Geological Survey, 2000, Collection and use of total suspended solids data: U.S. Geological Survey Office of Water Quality and Office of Surface Water Technical Memorandum 2001.03. [Also available at http://water.usgs.gov/admin/memo/SW/sw01.03.html.]

Van Buren, M.A., Watt, W.E., and Marsalek, J., 1997, Applications of the log-normal and normal distributions to stormwater quality parameters: Water Research, v. 31, no. 1, p. 95-104. [Also available at https://doi.org/10.1016/ S0043-1354(96)00246-1.]

Vogel, R.M., Rudolph, B.E., and Hooper, R.P., 2005, Probabilistic behavior of water-quality loads: Journal of Environmental Engineering, v. 131, no. 7, p. 1081-1089. [Also available at https://doi.org/10.1061/(ASCE)07339372(2005)131:7(1081).]
Wagner, C.R., Fitzgerald, S.A., Sherrell, R.D., Harned, D.A., Staub, E.L., Pointer, B.H., and Wehmeyer, L.L., 2011, Characterization of stormwater runoff from bridges in North Carolina and the effects of bridge deck runoff on receiving streams: U.S. Geological Survey Scientific Investigations Report 2011-5180, 95 p., 8 appendix tables. [Also available at https://doi.org/10.3133/sir20115180.]

Wanielista, M.P., Hardin, M., Runnebaum, N., and Cohen, R., 2010, Recharge and runoff from urban impervious surfaces, in 2010 Annual Florida Stormwater Association Conference, Fort Myers, Fla., June 2010: Florida Stormwater Association, accessed January, 1, 2012, at http://www.stormwater.ucf.edu/research/ FSAJune2010meeting.pdf.

Waschbusch, R.J., 2003, Data and methods of a 1999-2000 street sweeping study on an urban freeway in Milwaukee County, Wisconsin: U.S. Geological Survey Open-File Report 03-93, 41 p. [Also available at https://doi.org/10.3133/ofr0393.]

Weaver, J.C., 2006, Frequency of annual maximum precipitation in the city of Charlotte and Mecklenburg County, North Carolina, through 2004: U.S. Geological Survey Scientific Investigations Report 2006-5017, 53 p. [Also available at https://doi.org/10.3133/sir20065017.]

Weaver, J.C., 2016, Low-flow characteristics and flowduration statistics for selected USGS continuous-record streamgaging stations in North Carolina through 2012 (ver. 1.1, March 2016): U.S. Geological Survey Scientific Investigations Report 2015-5001, 89 p. [Also available at https://doi.org/10.3133/sir20155001.]

Weaver, J.C., Feaster, T.D., and Gotvald, A.J., 2009, Magnitude and frequency of rural floods in the Southeastern United States, through 2006-Volume 2, North Carolina: U.S. Geological Survey Scientific Investigations Report 2009-5158, $111 \mathrm{p}$.

Weaver, J.C., Granato, G.E., and Fitzgerald, S.A., 2019, Assessing water quality from highway runoff at selected sites in North Carolina with the Stochastic Empirical Loading and Dilution Model (SELDM): U.S. Geological Survey data release, https://doi.org/10.5066/F7V69HV8.

Weibull, W., 1939, The phenomenon of rupture in solids: Stockholm, Ingeniors Vetenskaps Akademien Handlinga $153,55 \mathrm{p}$.

Wiles, T.J., and Sharp, J.M., Jr., 2008, The secondary permeability of impervious cover: Environmental and Engineering Geoscience, v. 14, no. 4, p. 251-265. [Also available at https://doi.org/10.2113/gseegeosci.14.4.251.] 
Winston, R.J., Hunt, W.F., Kennedy, S.G., and Wright, J.D., 2011, Evaluation of permeable friction course (PFC), roadside filter strips, dry swales, and wetland swales for treatment of highway stormwater runoff: Raleigh, N.C., North Carolina Department of Transportation, Final Report, North Carolina Department of Transportation Research Project 2007-21, 110 p.

Winter, T.C., 1981, Uncertainties in estimating the water balance of lakes: Water Resources Bulletin, v. 17, no. 1, p. 82-115. [Also available at https://doi.org/10.1111/j.1752-1688.1981.tb02593.x.]

Wright Water Engineers, Inc., and Geosyntec Consultants, 2016, International Stormwater Best Management Practices (BMP) Database-User's guide for BMP data entry spreadsheets, release version 3.3: International Stormwater BMP database, 104 p., accessed July 2, 2018, at http://www.bmpdatabase.org/Docs/2016_BMP_Database_ Users_Guide.pdf.

Wu, J.S., and Allan, C.J., 2001, Sampling and testing of stormwater runoff from North Carolina highways: Charlotte, N.C., University of North Carolina at Charlotte, Final Report FHWA/NC/2001-002, North Carolina Department of Transportation Research Project 1999-06, 101 p.

Wu, J.S., and Allan, C.J., 2013, Stormwater characterization from roadways with open graded friction course surfaces: Charlotte, N.C., University of North Carolina at Charlotte, Final Report, North Carolina Department of Transportation Research Project 2011-16, 152 p.

Wu, J.S., and Allan, C.J., 2014, Evaluation of nutrient loading rates and effectiveness of roadside vegetative connectivity for managing runoff from secondary roadways: Charlotte, N.C., University of North Carolina at Charlotte, Final Report, North Carolina Department of Transportation Research Project 2007-04, 110 p.

Ying, G., and Sansalone, J., 2008, Granulometric relationships for urban source area runoff as a function of hydrologic event classification and sedimentation: Water, Air, and Soil Pollution, v. 193, nos. 1-4, p. 229-246. [Also available at https://doi.org/10.1007/s11270-008-9685-0.]
For more information about this report, contact Director, South Atlantic Water Science Center U.S. Geological Survey 720 Gracern Road Stephenson Center, Suite 129 Columbia, SC 29210

Or visit the South Atlantic Water Science Center website at https://www.usgs.gov/centers/sa-water 

